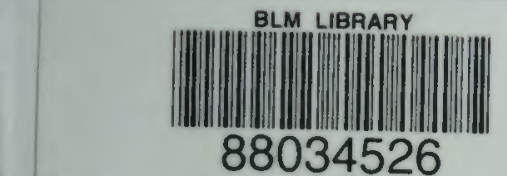

(4)

Department of

Agriculture

Forest Service

UAS

(a)

Department of

the Interior

Bureau of Land

Management

3

United States

Department of

Health and

Human Services

Food and Drug

Administration

FDA

\section{Pacific Vew}

\section{Final Environmental Impact Statement}

September, $1993 \square$ Appendices - Volume 2

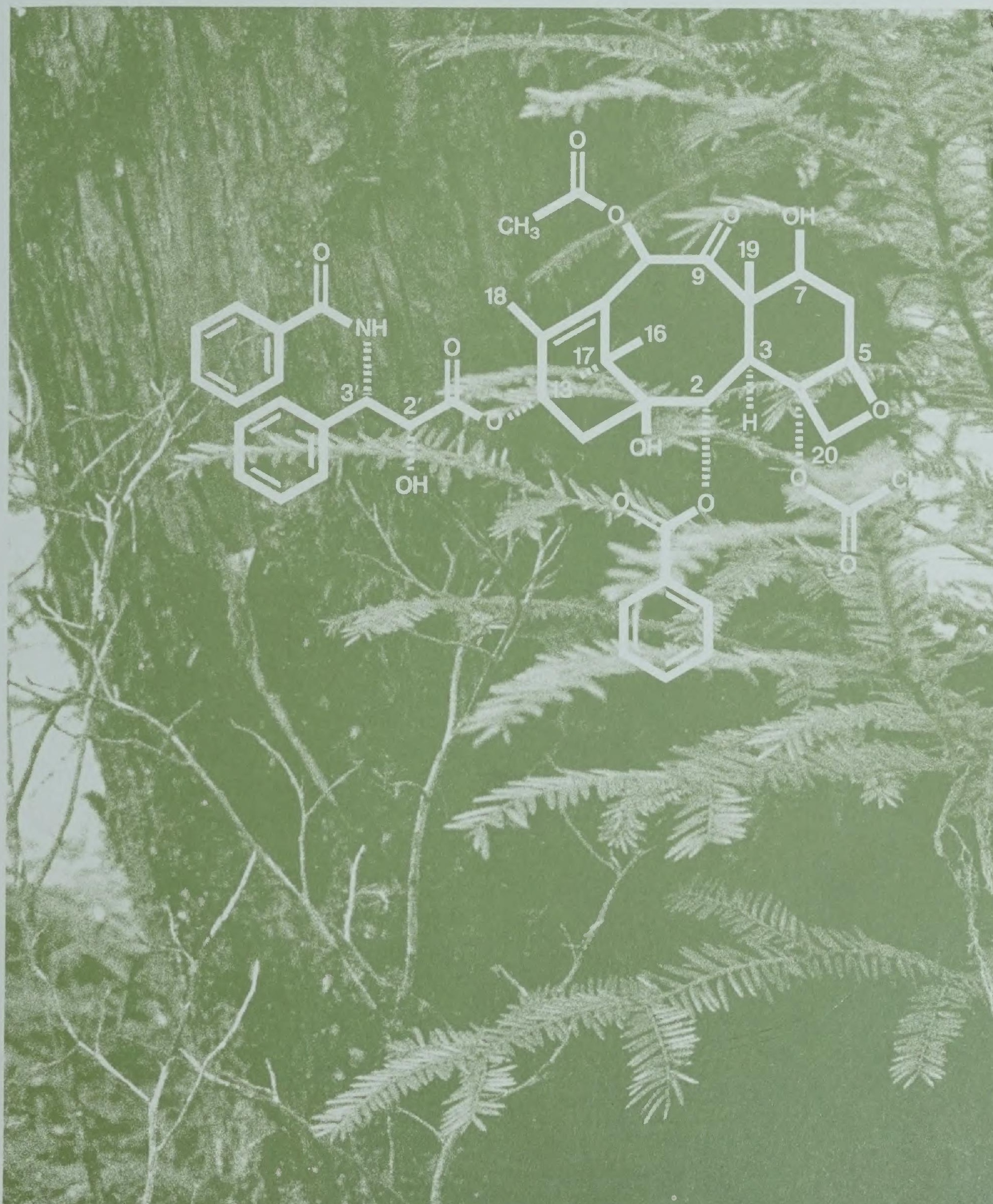




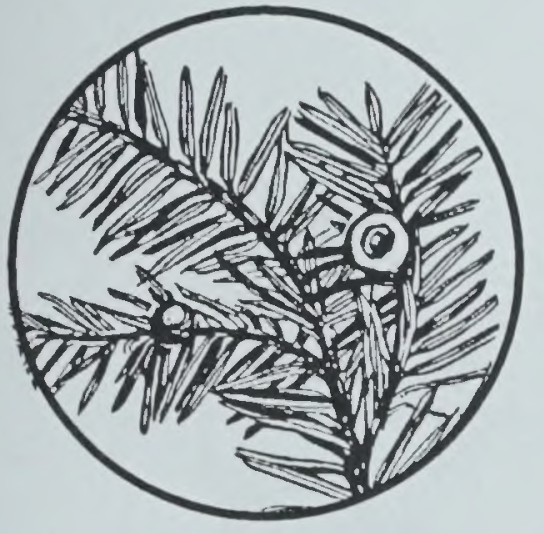

Appendix B

Monitoring

\section{Appendix C}

Analysis Process

for Port-Orford-Cedar

\section{Appendix D}

Land Ownerships

\section{Appendix $\mathrm{E}$}

Bristol-Myers Squibb and

Federal Government Agreements

\section{Appendix $F$}

Pacific Yew Inventories

\section{Appendix $\mathbf{G}$}

Insects and Diseases

of Pacific Yew

\section{Appendix $\mathrm{H}$}

Pacific Yew Plant Associations

\section{Appendices \\ Volume 2}

Pacific Yew Final Environmental Impact Statement

Contents

\section{Appendix I \\ Soils}

\section{Appendix J}

Wildlife and Biological Assessment

\section{Appendix K}

Taxol

\section{Appendix L}

\section{Cultural History of Pacific Yew}

\section{Appendix M}

Ongoing and Needed

Research for Pacific Yew

\section{Appendix N}

Pacific Yew Act

\section{Appendix $\mathrm{O}$}

Annotated Bibliography 



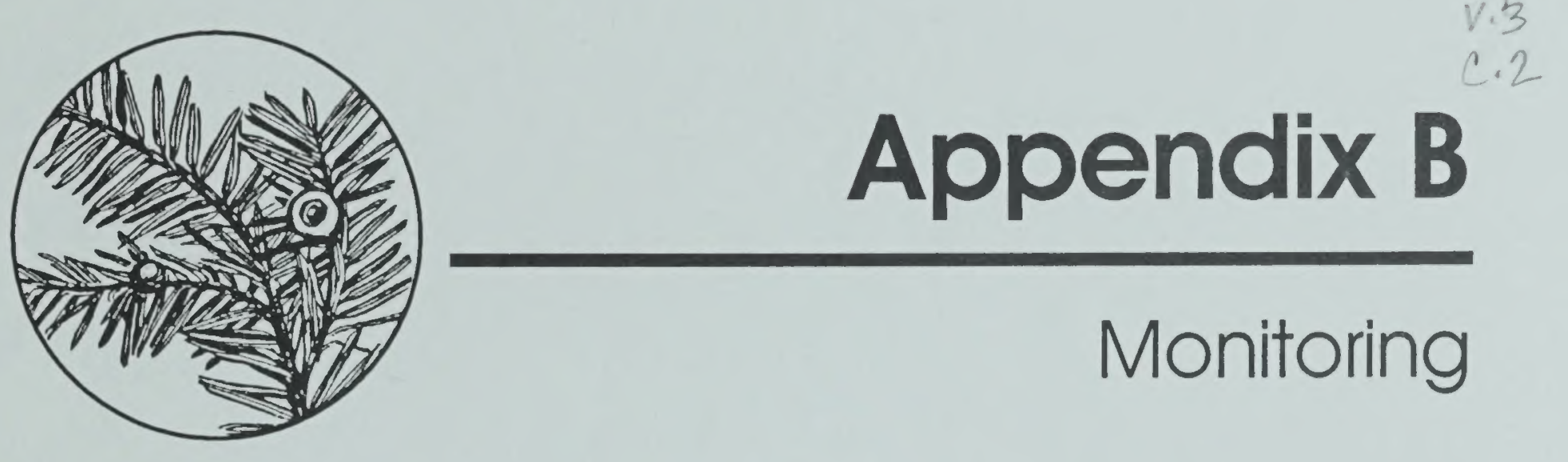


Changes Made Since the Draft EIS

Appendix B

No Changes. 
The following two monitoring measures are suggested as ways to better achieve harvest and regeneration goals.

1. Monitor yew regeneration on timber sale units in conjunction with other conifer regeneration surveys. Additional useful information that could be collected includes:

a. Compare yew stump and residual survival and growth following different site preparation methods (e.g. prescribed burns, slash and pile, yarding unmerchantable timber [YUM], etc.);

b. Determine occurrence, distribution, and associated physical and biotic habitat of natural seedlings;

c. Compare growth and survival of planted seedlings, planted rooted cuttings, and natural seedlings; and

d. Determine relative effectiveness of animal protection measures.

The main purpose of this monitoring measure is to identify those timber sale units where yew regeneration is not meeting the silvicultural prescription and where remedial regeneration is required. Any additional information that is gathered will increase our knowledge about stock types, optimal seed bed conditions, and animal protection, and will help us in future propagation and

regeneration efforts.

2. Monitor diameter class populations and distribution before and after harvest in partial-cut and non-sale areas. This monitoring can be carried out in conjunction with pre-sale work, contract compliance monitoring, or as part of the yew harvest permit administration procedure. The post-harvest survey should be done as soon as possible after harvest in order to provide as much feedback and adjustment of methods as possible within the same field season.

The purpose of this monitoring measure is to ensure that we harvest the correct amount of trees or shrubs and that we retain the correct percentage or minimum number as required by the selected alternative. Another purpose is to compare different methods of implementation. Where yew is sparsely and unevenly distributed, removal of a percentage of trees in each diameter class,

\section{Monitoring}


particularly with retention of a minimum number of trees per acre, is not easy to implement. A number of different pre-harvest inventory and marking methods will most likely be tried to find one or more that will result in accurate harvest and retention percentages while minimizing error, cost, and time. This monitoring measure allows different methods to be evaluated and compared. 


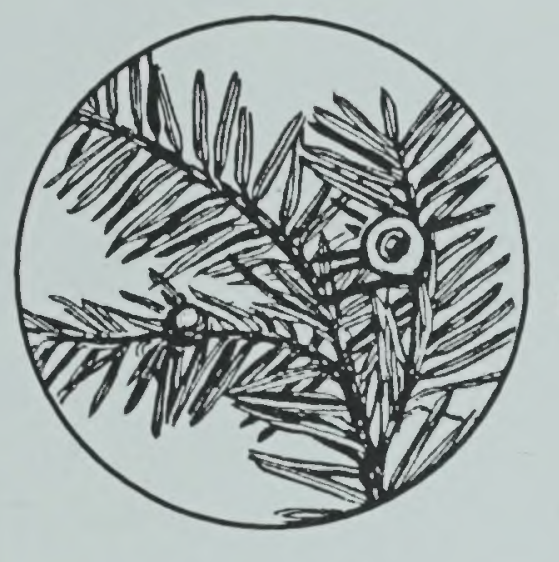

\section{Appendix C}

Analysis Process for Port-Orford-Cedar 


\section{Changes Made Since the Draff EIS Appendix C}

Changed this appendix from Mitigation Measures to Port-Orfordcedar Analysis Process. The Mitigation Measures are fully described in Chapter II, except for the mitigation measures for Yew Harvest in Port-Orford-cedar Areas. These will follow the same analysis process developed for the management of Port-Orford-cedar root disease which is provided in this appendix. 
Management of Pacific yew in areas within the natural range of Port-Orford-cedar (POC) will follow the same analysis processes developed for management of Port-Orford-cedar root disease. The standards, guidelines, or mitigation measures to use are determined by using the following process to analyze the risk inherent in various management activities.

Steps in the Port-Orford-cedar Analysis Process:

1. Management direction for Port-Orford-cedar;

2. Project description;

3. Management objectives by subunit;

4. Risk assessment - matrix and narrative;

5. Disease control measures - listing and cost analysis;

6. Potential impact - analysis and narrative;

7. Monitoring;

8. Public involvement; and

9. Maps.

1. Management Direction for Port-Orford-cedar: USDA Forest Service Region Five/Region Six Port-Orford-cedar Root Disease Action Plan - June 29, 1988. This is a formal commitment by both regional foresters for (1) Inventory and Monitoring, (2) Research, (3) Public Involvement and Education, and (4) Management Policy. In short, this commitment provides the support to ensure the viability and continued presence of Port-Orford-cedar in the ecosystem throughout its native range on Forest Service managed lands.

- List forest plan standards and guidelines related to PortOrford-cedar.

- List project-level direction relating to Port-Orford-cedar (special management area concerns, issues with the Proposed Action of the project, etc.).

2. Description of Project: Brief description of project (acres, number of units, haul route, and activities with risk of spreading disease).

3. Management Objectives by Subunit: Delineate subunits that have similar management objectives based on current disease status. A subunit may be a drainage, an area behind a gate, a road segment, a group of timber harvest units, or

\section{Analysis Process for Port-Orford- Cedar}


any other logical delineation. A subunit may have more than one objective (see examples B and C). Post-activity monitoring will decide on success of control strategies in meeting objectives of each subunit.

Objective

A Prevent the import of disease into uninfected areas (off-site spores picked up and carried into uninfected project area).

B Prevent the export of disease to uninfected areas (on-site spores moved to off-site uninfected area).

C Minimize the rate of spread in areas where the disease is endemic or infection is intermittent.

\section{Risk Assessment Matrix and Narrative:}

\begin{tabular}{|c|c|c|c|}
\hline \multirow[b]{2}{*}{$\begin{array}{c}\text { Percent POC } \\
\text { (IMPACT) }\end{array}$} & \multicolumn{3}{|c|}{ Proximity of POC to Roads (Hazard) } \\
\hline & $\begin{array}{c}\text { Low } \\
>500 \mathrm{ft} \text {. below } \\
>50 \mathrm{ft} \text {. above }\end{array}$ & $\begin{array}{l}\text { Moderate } \\
>100-500 \mathrm{ft} \text {. below } \\
>50 \mathrm{ft} \text {. above }\end{array}$ & $\begin{array}{c}\text { High } \\
<100 \mathrm{ft} \text {. below } \\
<50 \mathrm{ft} \text {. above }\end{array}$ \\
\hline $\begin{array}{l}\text { Low } \\
(1-5 \%)\end{array}$ & $\begin{array}{l}\text { Low } \\
\text { Risk }\end{array}$ & $\begin{array}{l}\text { Low } \\
\text { Risk }\end{array}$ & $\begin{array}{l}\text { Moderate } \\
\text { Risk }\end{array}$ \\
\hline $\begin{array}{c}\text { Moderate } \\
(5-20 \%)\end{array}$ & $\begin{array}{l}\text { Low } \\
\text { Risk }\end{array}$ & $\begin{array}{c}\text { Moderate } \\
\text { Risk }\end{array}$ & $\begin{array}{l}\text { High } \\
\text { Risk }\end{array}$ \\
\hline $\begin{array}{l}\text { High } \\
(>20 \%)\end{array}$ & $\begin{array}{l}\text { Moderate } \\
\text { Risk }\end{array}$ & $\begin{array}{l}\text { High } \\
\text { Risk }\end{array}$ & $\begin{array}{l}\text { High } \\
\text { Risk }\end{array}$ \\
\hline
\end{tabular}

Select a risk level for the whole project and each subunit, and describe your reasons. Considerations should include: large uninfested drainages with high priority for disease protection; water use away from roads; increased access by non-project activities; number of soil-disturbing activities scheduled; distance to nearest infection source; and roadside POC with disease immediately downstream. 
Projects or subunits with HIGH risk should have disease control measures applied and/or may trigger the need for notification of key people who might have technical knowledge that would be helpful in the analysis process. Projects or subunits with MODERATE or LOW risk may have few or no disease control measures applied, based on site-specific concerns.

5. Disease Control Measures: Select disease control strategies below that meet management objectives. Modify the wording as needed to fit a given situation and list the subunits to which this prescriptive element applies. An option would be to have a list of control strategies for each subunit. Delete those strategies which do not apply.

\section{Engineering and Road Management (E):}

E-1 Road locations should be made, when possible, below cedar areas or on opposite sides of ridges.

E-2 Control drainage from roads so that it is concentrated into existing stream channels when possible.

E-3 Locate and design waste areas so they do not spread infection spores.

E-4 Limit road construction/maintenance and associated slash disposal to the dry season.

E-5 Machinery and vehicles working and traveling on road need to be washed before entering project areas.

E-6 Wash equipment before leaving infected areas.

E-7 Close roads with guardrails, gates, physical blockades, or "putting to bed." Restrict product utilization and management activities to the dry season (June 1 through September 30). Maintenance and enforcement is included.

E-8 Avoid use of potentially infected water (for such projects as dust abatement, compaction, excavation, seeding, fire suppression, etc.) or treat water with chlorine.

E-9 Where conditions permit, establish and maintain an insloped road template and site-specific berms on the outside edges of roads to prevent downslope flow of 
contaminated water.

E-10 Establish road rules to prevent timber haul during periods when spores will be spread widely.

E-11 Access to the project area will be along routes with least occurrence of infection sites.

E-12 Pave or add uninfected rock to raise roadbed a minimum of 12 inches, to length of 50 feet before and after infection site.

E-13 When compaction water creates adverse wet conditions in high-sensitivity areas, water rock at the rock pit or other agreed-to sites prior to hauling to the construction area.

E-14 Use of surfacing materials appropriate for dry-weather haul (i.e., pit-run grid-rolled rock, sandstone, oil, lignin, pavement). Avoid creation of wet road conditions in high-sensitivity areas. The alternative is to require dry haul on dirt surfacing - rip, seed, and close road.

\section{Timber Harvest (T):}

T-1 Limit the operating season of timber sale operations to the drier months (June 1 to September 30) and discontinue operations during periods of rain or wet weather.

T-2 Harvest the units in priority order to minimize the spread of spores to uninfected areas. Infected units may be harvested after uninfected units.

T-3 When feasible, plan downhill logging to avoid road construction above an uninfected stand.

T-4 Use helicopter logging to protect high value cedar stands.

T-5 Use service contracts to harvest timber with more control of activities.

T-6 Wash logging trucks and other equipment when moving from infected to uninfected areas or subdivisions.

T-7 Wash logging equipment prior to entering sale areas. 


\section{Stand Management (S):}

S-1 Identify low risk areas and emphasize maintaining and/or introducing Port-Orford-cedar into the species mix.

S-2 Plant POC singly at $25 \mathrm{ft}$. spacing or in groups of 10-20 trees at $100 \mathrm{ft}$. spacing, independent of other stocking.

S-3 Avoid planting $\mathrm{POC}$ within 50 feet of roads, streams or wet areas.

S-4 During precommercial thinning (PCT) thin POC at a 25 foot spacing, independent of other crop trees, or space POC in groups 100 feet apart where possible.

S-5 As part of PCT, remove POC from areas adjacent to roads, streams and other high risk areas.

S-6 To ensure the presence of POC through the rotation, leave thrifty cedar during commercial thinning.

S-7 Manage the cedar component of the stand on a longer rotation than the other associated conifers. Example: Carry cedar through two or three fir rotations.

S-8 Plant container-grown POC until bare root stock can be certified disease free at the Nursery.

S-9 Indicate in stand records [GIS, etc.] that POC protection measures have been implemented.

S-10 Minimize management entries during wet weather. Wash vehicles when such entries are made. Associated with formal road closure. Maintain consistency with requirements of sale purchasers, public.

S-11 Where possible, coordinate prevention/control activities with adjacent private landowners.

S-12 Remove/sanitize POC from high risk portion of road sides. Accomplish work during the dry season between June 1 and September 30.

S-13 Post-activity monitoring (biannual field monitoring checklist; annual monitoring report due December 1st). 


\section{Other (O):}

O-1 Administrative closure orders. (CFR CLOSURE; SIGN PLAN)

O-2 Coordinate other products utilization with $\mathrm{POC}$ control needs and road closures. Examples: fuelwood cutting, cedar bough cutting.

O-3 Avoid using potentially infected water sources for fire suppression, or treat water with chlorine (12 fl.oz./ 1000 gallons).

\section{Disease Control Cost/Effectiveness Estimate}

\begin{tabular}{|l|c|c|c|}
\hline & $\begin{array}{c}\text { Net Estimated } \\
\text { Effectiveness }\end{array}$ & $\begin{array}{c}\text { Direct } \\
\text { FS Cost* }\end{array}$ & $\begin{array}{c}\text { Indirect } \\
\text { User Cost }\end{array}$ \\
\cline { 2 - 4 } $\begin{array}{l}\text { All Treatments } \\
\text { All - }\end{array}$ & High & Medium \\
\hline $\begin{array}{l}\text { Monitoring } \\
\text { Requirements: } \\
\text { Drive and } \\
\text { walk-through } \\
\text { inspections associated } \\
\text { with this project. }\end{array}$ & Medium & \\
& & & \\
\hline * Cost Definitions: Low & $=<\$ 1,000$ & \\
Medium & $=\$ 1,000-\$ 10,000$ & \\
High & $=>\$ 10,000$
\end{tabular}

6. Potential Impact Analysis: This section is to provide a more thorough analysis of the potential impact of the project after considering prescribed control measures. Assess the potential indirect and cumulative effects of the planned activity. Consider the beneficial and/or uncertain effects of the mitigation measures prescribed above for both onsite and offsite/downstream stands. This task should include the interdisciplinary team for the purpose of estimating impacts to other resources. 
a. Following mitigation, is P.lateralis likely to infect a major amount of the analysis area? [Ref. CEQ Reg. 1508.27] If $\mathrm{NO}$, then no secondary or cumulative effect. If YES, continue. (YES/NO). (Major amount of the analysis area refers to (1) great or large in relative importance to POC existence in the near proximity and over its range, (2) notable or conspicuous in effect or scope (e.g., visually detracting), or (3) posing a serious risk to the ecosystem, its neighbor $\mathrm{POC}$ and the total population.);

b. Will the potential secondary and cumulative effects cause meaningful levels of mortality? (YES/NO) Explain decision in narrative. (Meaningful levels of mortality is a mortality rate of 25 percent of existing Port-Orford-cedar over the next 20 year period.); and

c. Write a potential impact narrative to document the basis for each decision on the previous questions.

7. Monitoring: Refer to the POC monitoring plan and list here the subunits that need to be monitored and when. Include specific locations of concern, such as roads, harvest units, drainages, etc. Post-activity monitoring will decide on success of control measures in meeting management objectives for each subunit.

8. Public Involvement: Briefly describe how you have incorporated public involvement in the disease control strategy (scoping, field visits, etc.).

Control Strategy Prepared By:

Approved By: (As appropriate) 
9. Port-Orford-cedar Analysis Map: This map should show all details of the project which allow the reader to fully understand the prescription. The infection status of each road, harvest unit, etc. should be displayed.

Please note: The BLM Port-Orford-cedar Management Plan is still being prepared at the time this EIS is going to print. For a copy of the plan, please contact:

Kent Tresidder

Oregon State Office

Bureau of Land Management

Branch of Forestry

P.O. Box 2965

Portland, OR 97208 


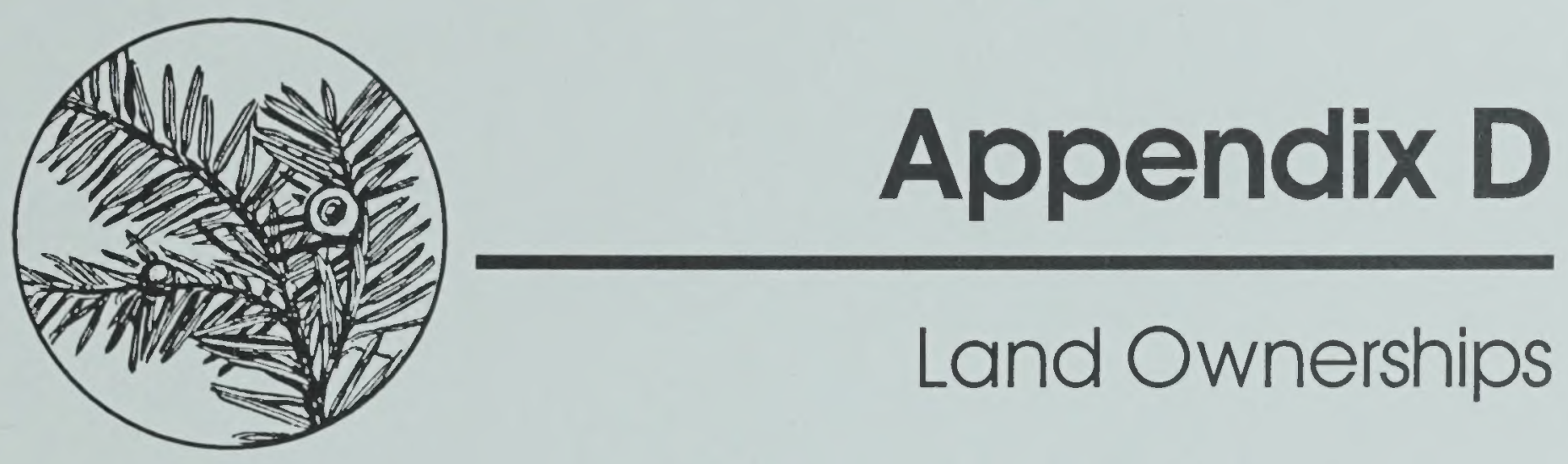




\section{Changes Made Since the Draft EIS}

\section{Appendix D}

No Changes. 


\section{Appendix D}

\section{Land Ownerships}

\section{Table of Contents}

Introduction

Table D-1 — USDA Forest Service-Administered Lands

in the Native Range of Pacific Yew....

Table D-2 - USDI Bureau of Land Management-Administered Lands

in the Native Range of Pacific Yew ...

Table D-2 - USDI Bureau of Indian Affairs-Administered Lands

in the Native Range of Pacific Yew

Table D-5 - Lands in Other Ownerships

in the Native Range of Pacific Yew

Figure D-1 — Pacific Yew Native Range (Washington) ........................ 7

Figure D-2 — Pacific Yew Native Range (Oregon) ................................ 8

Figure D-3 — Pacific Yew Native Range (California) .............................. 9

Figure D-4 - Pacific Yew Native Range (Northern Idaho

and Western Montana)

Figure D-5 - Pacific Yew Native Range within

Bureau of Land Management Lands

(Washington, Oregon, California, Idaho, Western Montana) 

The following tables and maps provide information on administra-

\section{Introduction} tive units within the native range of the Pacific yew. The tables and maps are based on interpretation of the Pacific Yew Native Range Map 86W and 86N in Little, March, 1971; "Atlas of U.S. Trees, Vol. 1, Conifers and Important Hardwoods, USDA-Forest Service; Misc. Publication 1146; by Elbert L. Little, Jr.

\section{Table D-1: USDA-Forest Service-Administered Lands in the Native Range of Pacific Yew}

\begin{tabular}{|c|c|c|c|}
\hline State & National Forest & Wildernesses and & National Monuments \\
\hline \multirow[t]{6}{*}{ Washington } & Olympic & $\begin{array}{l}\text { Buckhorn } \\
\text { Colonel Bob } \\
\text { Mount Skokomish }\end{array}$ & $\begin{array}{l}\text { The Brothers } \\
\text { Wonder Mountain }\end{array}$ \\
\hline & $\begin{array}{l}\text { Mount } \\
\text { Baker-Snoqualmie }\end{array}$ & \begin{tabular}{|l|} 
Mount Baker \\
Glacier Peak \\
Noisy-Diobsud \\
Boulder River
\end{tabular} & $\begin{array}{l}\text { Henry M. Jackson } \\
\text { Alpine Lakes } \\
\text { Clearwater } \\
\text { Norse Peak }\end{array}$ \\
\hline & Gifford Pinchot & $\begin{array}{l}\text { William O. Douglas } \\
\text { Goat Rocks } \\
\text { Glacier View } \\
\text { Tatoosh } \\
\text { Mount Adams }\end{array}$ & $\begin{array}{l}\text { Indian Heaven } \\
\text { Trapper Creek } \\
\text { Mount St. Helens } \\
\text { National Monument }\end{array}$ \\
\hline & Colville & Salmo-Priest & \\
\hline & Wenatchee & $\begin{array}{l}\text { Glacier Peak } \\
\text { Henry M. Jackson } \\
\text { Alpine Lakes } \\
\text { Norse Peak } \\
\end{array}$ & $\begin{array}{l}\text { Lake Chelan-Sawtooth } \\
\text { William O. Douglas } \\
\text { Goat Rocks }\end{array}$ \\
\hline & Umatilla (WA) & Wenaha-Tucannon & \\
\hline
\end{tabular}


Table D-1: USDA-Forest Service-Administered Lands in the Native Range of Pacific Yew (continued)

\begin{tabular}{|c|c|c|c|}
\hline State & National Forest & Wildernesses and I & Vational Monuments \\
\hline \multirow[t]{10}{*}{$\overline{\text { Oregon }}$} & Mount Hood & $\begin{array}{l}\text { Mount Jefferson } \\
\text { Mount Hood } \\
\text { Badger Creek } \\
\end{array}$ & $\begin{array}{l}\text { Columbia } \\
\text { Bull of the Woods } \\
\text { Salmon-Huckleberry }\end{array}$ \\
\hline & Siuslaw & $\begin{array}{l}\text { Cummins Creek } \\
\text { Drift Creek }\end{array}$ & Rock Creek \\
\hline & Willamette & $\begin{array}{l}\text { Mount Jefferson } \\
\text { Mount Washington } \\
\text { Three Sisters } \\
\text { Diamond Peak }\end{array}$ & $\begin{array}{l}\text { Bull of the Woods } \\
\text { Middle Santiam } \\
\text { Menagerie } \\
\text { Waldo Lake }\end{array}$ \\
\hline & Deschutes & \begin{tabular}{|l} 
Mount Jefferson \\
Mount Washington \\
Three Sisters \\
\end{tabular} & $\begin{array}{l}\text { Diamond Peak } \\
\text { Mount Thielson }\end{array}$ \\
\hline & Umpqua & \begin{tabular}{|l|} 
Mount Thielsen \\
Rogue-Umpqua Divide
\end{tabular} & Boulder Creek \\
\hline & Winema & \begin{tabular}{|l} 
Mount Thielsen \\
Sky Lakes \\
\end{tabular} & Mountain Lakes \\
\hline & Siskiyou & $\begin{array}{l}\text { Grassy Knob } \\
\text { Kalmiopsis } \\
\text { Red Buttes } \\
\end{array}$ & $\begin{array}{l}\text { Siskiyou } \\
\text { Wild Rogue }\end{array}$ \\
\hline & Rogue River & \begin{tabular}{|l|} 
Sky Lakes \\
Red Buttes \\
\end{tabular} & Rogue-Umpqua Divide \\
\hline & Umatilla (OR) & North Fork Umatilla & North Fork John Day \\
\hline & Wallowa-Whitman & $\begin{array}{l}\text { Monument Rock } \\
\text { North Fork John Day }\end{array}$ & $\begin{array}{l}\text { Eagle Cap } \\
\text { Hells Canyon } \\
\end{array}$ \\
\hline
\end{tabular}


Table D-1: USDA-Forest Service-Administered Lands in the Native Range of Pacific Yew (continued)

\begin{tabular}{|c|c|c|c|}
\hline State & National Forest & Wildernesses an & National Monuments \\
\hline \multirow{11}{*}{$\begin{array}{l}\text { Northern } \\
\text { California }\end{array}$} & Klamath & Red Buttes & Russian \\
\hline & & Siskiyou & Trinity Alps \\
\hline & & Marble Mountain & \\
\hline & Six Rivers & Siskiyou & North Fork \\
\hline & & Trinity Alps & Yolla Bolly-Middle Eel \\
\hline & Shasta-Trinity & $\begin{array}{l}\text { Mount Shasta } \\
\text { Castle Crags }\end{array}$ & Chanchelulla \\
\hline & Mendocino & Snow Mountain & Yolla Bolly-Middle Eel \\
\hline & Lassen & $\begin{array}{l}\text { Thousand Lakes } \\
\text { Caribou }\end{array}$ & Ishi \\
\hline & Plumas & Bucks Lake & \\
\hline & Tahoe & Granite Chief & \\
\hline & Eldorado & Desolation & Mokelumne \\
\hline \multirow{5}{*}{$\begin{array}{l}\text { Northern } \\
\text { Idaho }\end{array}$} & Idaho Panhandle & Salmo Priest & \\
\hline & Clearwater & Selway-Bitterroot & \\
\hline & Nez Perce & $\begin{array}{l}\text { Selway-Bitterroot } \\
\text { Gospel Hump }\end{array}$ & $\begin{array}{l}\text { Frank Church-River } \\
\text { of No Return }\end{array}$ \\
\hline & & Hells Canyon & \\
\hline & Bitterroot & Selway-Bitterroot & \\
\hline \multirow{3}{*}{$\begin{array}{l}\text { Western } \\
\text { Montana }\end{array}$} & Kootenai & Cabinet Mountains & \\
\hline & Flathead & $\begin{array}{l}\text { Great Bear } \\
\text { Bob Marshall }\end{array}$ & Mission Mountains \\
\hline & Lolo & NA & \\
\hline
\end{tabular}


Table D-2: USDI-Bureau of Land ManagementAdministered Lands in the Native Range of Pacific Yew

\begin{tabular}{|c|c|c|c|}
\hline State & Districts & \multicolumn{2}{|c|}{ Resource Areas } \\
\hline Washington & Spokane & Wenatchee & Border \\
\hline \multirow[t]{8}{*}{ Oregon } & Salem & $\begin{array}{l}\text { Tillamook } \\
\text { Yamhill } \\
\text { Clackamas }\end{array}$ & $\begin{array}{l}\text { Alsea } \\
\text { Santiam }\end{array}$ \\
\hline & Eugene & $\begin{array}{l}\text { Coast Range } \\
\text { McKenzie }\end{array}$ & South Valley \\
\hline & Roseburg & $\begin{array}{l}\text { Drain } \\
\text { North Umpqua }\end{array}$ & $\begin{array}{l}\text { South Umpqua } \\
\text { Dillard }\end{array}$ \\
\hline & Coos Bay & $\begin{array}{l}\text { Umpqua } \\
\text { Tioga }\end{array}$ & Myrtlewood \\
\hline & Medford & $\begin{array}{l}\text { Glendale } \\
\text { Butte Falls }\end{array}$ & $\begin{array}{l}\text { Grants Pass } \\
\text { Ashland }\end{array}$ \\
\hline & Prineville & Deschutes & Central Oregon \\
\hline & Lakeview & Klamath Falls & \\
\hline & Vale & Baker & \\
\hline \multirow{3}{*}{$\begin{array}{l}\text { Northern } \\
\text { California }\end{array}$} & Ukiah & Arcata & Redding \\
\hline & Susanville & Susanville & \\
\hline & Bakersfield & Sacramento & \\
\hline Northern Idaho & $\begin{array}{l}\text { Coeur } \\
\text { D'Alene } \\
\end{array}$ & Cottonwood & Emerald Empire \\
\hline $\begin{array}{l}\text { Western } \\
\text { Montana }\end{array}$ & N/A & & \\
\hline
\end{tabular}

Table D-3: USDI-National Park Service-Administered Lands in the Native Range of Pacific Yew

\begin{tabular}{|l|l|}
\hline \multicolumn{1}{|c|}{ State } & \multicolumn{1}{c|}{ National Park } \\
\hline Washington & $\begin{array}{l}\text { North Cascades } \\
\text { Mount Rainier } \\
\text { Olympic }\end{array}$ \\
\hline Oregon & Crater Lake \\
\hline Northern California & $\begin{array}{l}\text { Lassen Volcanic } \\
\text { Redwood }\end{array}$ \\
\hline Northem Idaho & N/A \\
\hline Western Montana & N/A \\
\hline
\end{tabular}




\section{Table D-4: USDI-Bureau of Indian Affairs-Administered Lands in the Native Range of Pacific Yew}

\begin{tabular}{|c|c|c|c|}
\hline \multirow{2}{*}{$\begin{array}{r}\text { State } \\
\text { Washington }\end{array}$} & \multicolumn{3}{|c|}{ American Indian Trust Lands } \\
\hline & \multicolumn{2}{|c|}{ West of Cascade Range } & East of C. R. \\
\hline & \begin{tabular}{|l} 
Nooksack \\
Lummi \\
Upper Skagit \\
Swinomish \\
Stillaguamish \\
Sauk-Suiattle \\
Tulalip \\
Makah \\
Quileute \\
Hoh \\
Quinault \\
\end{tabular} & $\begin{array}{l}\text { Lower Elwha } \\
\text { Ozette (Jamestown } \\
\quad \text { Klallam) } \\
\text { Port Gamble } \\
\text { Port Madison } \\
\text { Skokomish } \\
\text { Squaxin Island } \\
\text { Puyallup } \\
\text { Muckleshoot } \\
\text { Nisqually } \\
\text { Chehalis } \\
\text { Shoalwater Bay }\end{array}$ & $\begin{array}{l}\text { Yakima } \\
\text { Colville } \\
\text { Spokane } \\
\text { Kalispel }\end{array}$ \\
\hline \multirow[t]{2}{*}{ Oregon } & \multicolumn{2}{|c|}{ West of Cascade Range } & East of C. R. \\
\hline & $\begin{array}{l}\text { Grand Ronde } \\
\text { Siletz } \\
\text { Coos, Lower Umpqua, } \\
\text { and Siuslaw }\end{array}$ & $\begin{array}{l}\text { Cow Creek Band } \\
\text { of Umpqua } \\
\text { Klamath }\end{array}$ & $\begin{array}{l}\text { Warm Springs } \\
\text { Umatilla }\end{array}$ \\
\hline \multirow[t]{2}{*}{ Washington } & \multicolumn{2}{|c|}{\begin{tabular}{|l} 
West of Cascade Range \\
\end{tabular}} & East of C. R. \\
\hline & \begin{tabular}{|l} 
Nooksack \\
Lummi \\
Upper Skagit \\
Swinomish \\
Stillaguamish \\
Sauk-Suiattle \\
Tulalip \\
Makah \\
Quileute \\
Hoh \\
Quinault
\end{tabular} & $\begin{array}{l}\text { Lower Elwha } \\
\text { Ozette (Jamestown } \\
\quad \text { Klallam) } \\
\text { Port Gamble } \\
\text { Port Madison } \\
\text { Skokomish } \\
\text { Squaxin Island } \\
\text { Puyallup } \\
\text { Muckleshoot } \\
\text { Nisqually } \\
\text { Chehalis } \\
\text { Shoalwater Bay }\end{array}$ & $\begin{array}{l}\text { Yakima } \\
\text { Colville } \\
\text { Spokane } \\
\text { Kalispel }\end{array}$ \\
\hline \multirow[t]{2}{*}{$\begin{array}{l}\text { Northern } \\
\text { California }\end{array}$} & \multicolumn{2}{|c|}{ West of Interstate 5 (I-5) } & East of I-5 \\
\hline & \begin{tabular}{|l} 
Smith River \\
Karok \\
Resighini \\
Yurok \\
Big Lagoon \\
Trinidad \\
Hoopa Valley \\
Blue Lake \\
Round Valley \\
Laytonville \\
\end{tabular} & $\begin{array}{l}\text { Sherwood Valley } \\
\text { Redwood Valley } \\
\text { Coyote Valley } \\
\text { Pinoleville } \\
\text { Upper Lake } \\
\text { Robinson } \\
\text { Sulphur Bank } \\
\text { Hopland } \\
\text { Big Valley }\end{array}$ & $\begin{array}{l}\text { Lookout } \\
\text { Big Bend } \\
\text { Roaring Creek } \\
\text { Montgomery Cr. } \\
\text { Susanville } \\
\text { Greenville } \\
\text { Enterprise } \\
\text { Berry Creek }\end{array}$ \\
\hline Northern Idaho & Kootenai & Coeur D'Alene & Nez Perce \\
\hline $\begin{array}{l}\text { Western } \\
\text { Montana }\end{array}$ & Flathead & & \\
\hline
\end{tabular}


Table D-5: Lands in Other Ownerships in the Native Range of Pacific Yew

\begin{tabular}{|c|c|c|c|}
\hline State & \multicolumn{3}{|c|}{ County } \\
\hline \multirow[t]{11}{*}{ Washington } & \multicolumn{2}{|c|}{ West of Cascade Range } & East of C. R. \\
\hline & \multirow{10}{*}{\begin{tabular}{|l} 
Whatcom \\
San Juan \\
Skagit \\
Island \\
Snohomish \\
King \\
Clallam \\
Jefferson \\
Kitsap \\
Grays Harbor \\
\end{tabular}} & \multirow{10}{*}{$\begin{array}{l}\text { Mason } \\
\text { Thurston } \\
\text { Pierce } \\
\text { Lewis } \\
\text { Pacific } \\
\text { Wahkiakum } \\
\text { Cowlitz } \\
\text { Skamania } \\
\text { Clark }\end{array}$} & Klickitat \\
\hline & & & \begin{tabular}{|l} 
North west Area \\
\end{tabular} \\
\hline & & & Ferry \\
\hline & & & Stevens \\
\hline & & & Pend Oreille \\
\hline & & & Spokane \\
\hline & & & \begin{tabular}{|l} 
Southeast Area \\
\end{tabular} \\
\hline & & & Columbia \\
\hline & & & Garfield \\
\hline & & & Asotin \\
\hline \multirow[t]{10}{*}{ Oregon } & \multicolumn{2}{|c|}{ West of Cascade Range } & East of C. R. \\
\hline & \multirow{9}{*}{\begin{tabular}{|l} 
Clatsop \\
Columbia \\
Tillamook \\
Washington \\
Multnomah \\
Yamhill \\
Clackamas \\
Lincoln \\
Polk \\
\end{tabular}} & Marion & Hood River \\
\hline & & Linn & Wasco \\
\hline & & Benton & Jefferson \\
\hline & & Lane & Klamath \\
\hline & & Douglas & Northeast Area \\
\hline & & Coos & Umatilla \\
\hline & & Curry & Union \\
\hline & & Josephine & Wallowa \\
\hline & & Jackson & \\
\hline \multirow{6}{*}{$\begin{array}{l}\text { Northern } \\
\text { California }\end{array}$} & \multicolumn{2}{|c|}{ Northwest Area } & Northeast Area \\
\hline & Del Norte & Tehama & Lassen Nevada \\
\hline & Siskiyou & Mendocino & Plumas Placer \\
\hline & Humbolt & Glenn & Butte Eldorado \\
\hline & Trinity & Lake & Yuba Amador \\
\hline & Shasta & Colusa & Sierra \\
\hline \multirow{6}{*}{$\begin{array}{l}\text { Northern } \\
\text { Idaho }\end{array}$} & Boundary & Latah & \\
\hline & Bonner & Idaho & \\
\hline & Kootenai & Lewis & \\
\hline & Shoshone & Nez Perce & \\
\hline & Clearwater & & \\
\hline & Benewah & & \\
\hline \multirow{5}{*}{$\begin{array}{l}\text { Western } \\
\text { Montana }\end{array}$} & \multicolumn{2}{|c|}{ Northwest Area } & \\
\hline & Lincoln & Mineral & \\
\hline & Sanders & Missoula & \\
\hline & Flathead & Powell & \\
\hline & Lake & & \\
\hline
\end{tabular}


Figure D-1: Pacific Yew Native Range (Washington)

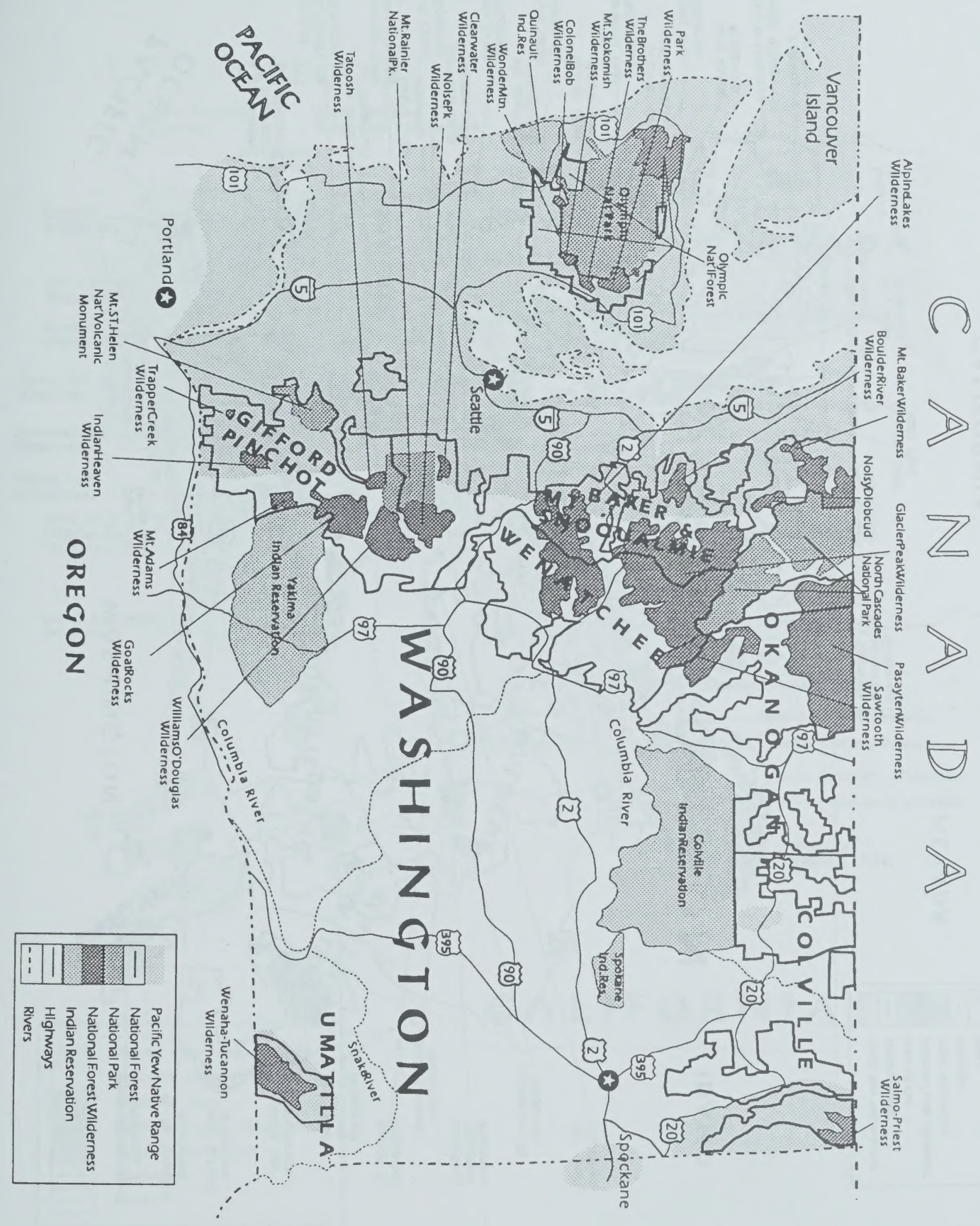


Figure D-2: Pacific Yew Native Range (Oregon)

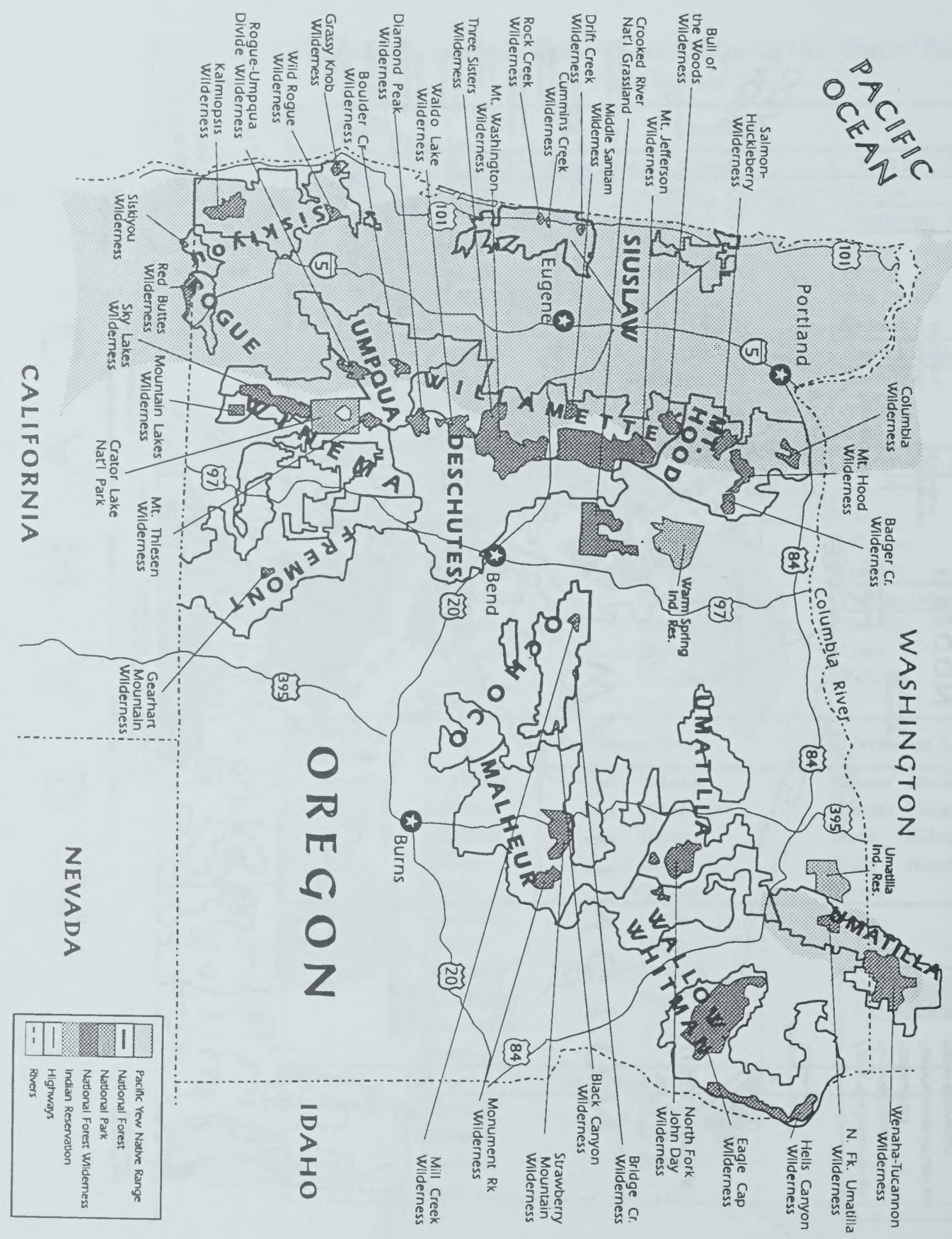




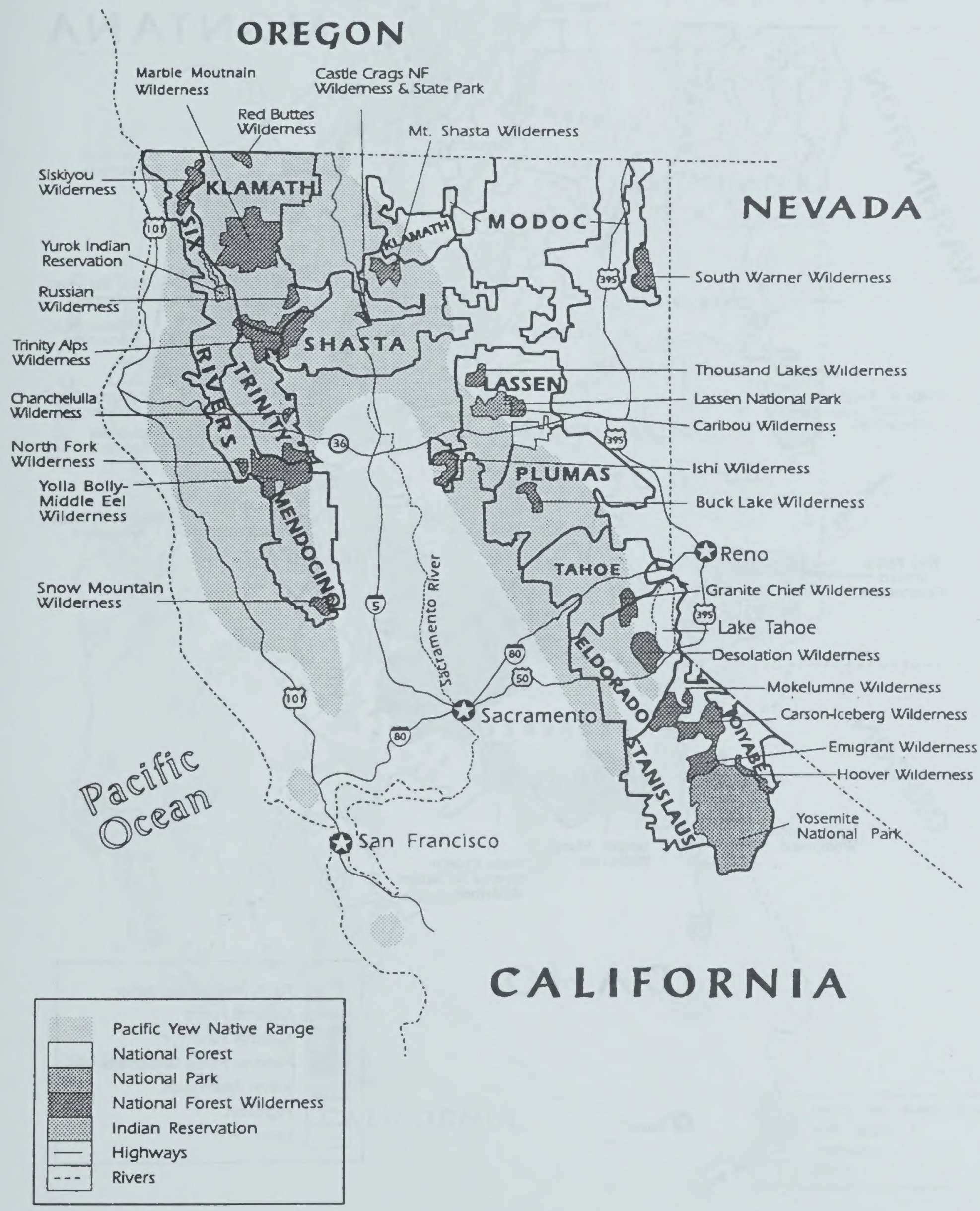




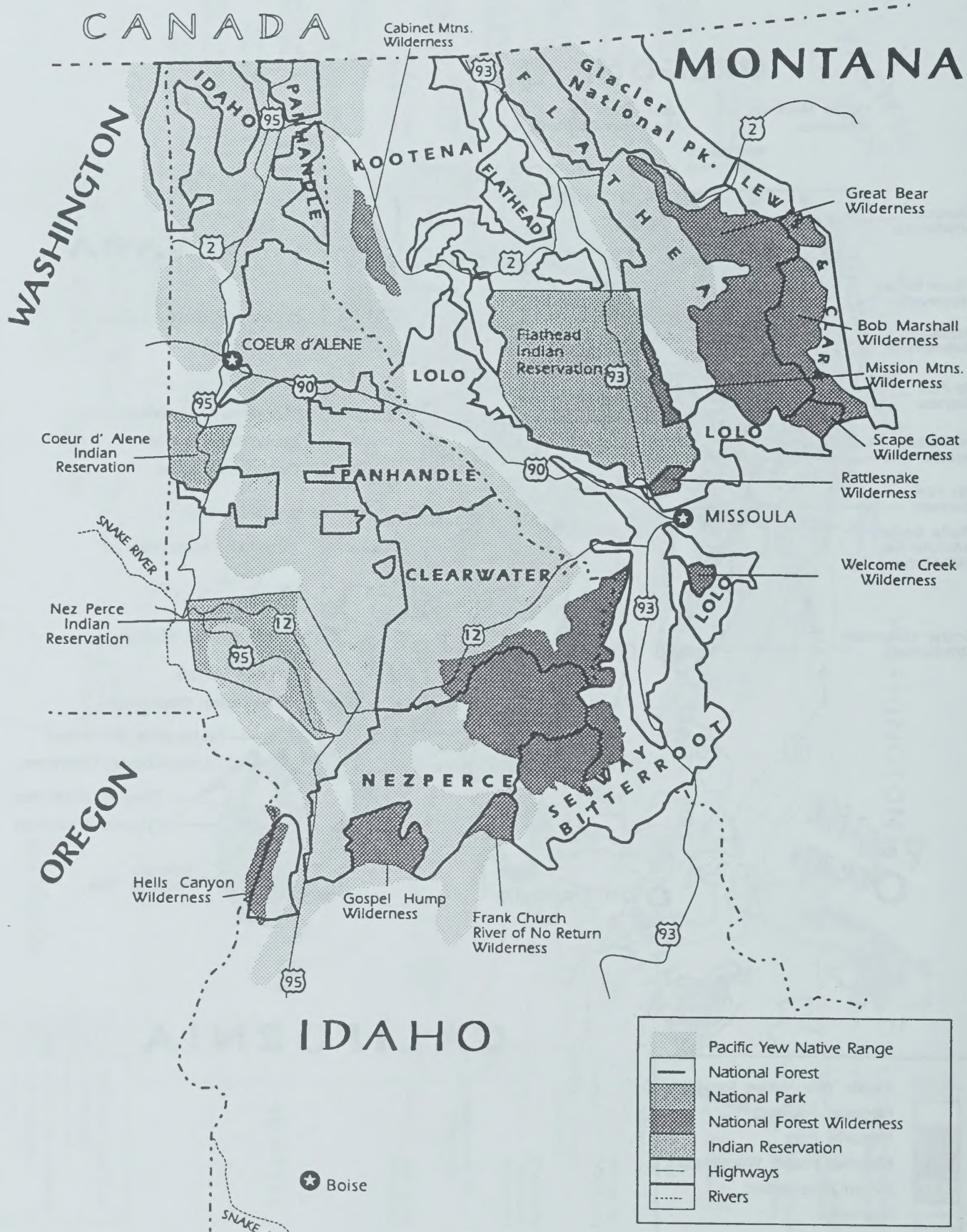


Figure D-5: Pacific Yew Native Range within Bureau of Land Management Lands*(Washington, Oregon, California, Idaho, Western Montana)

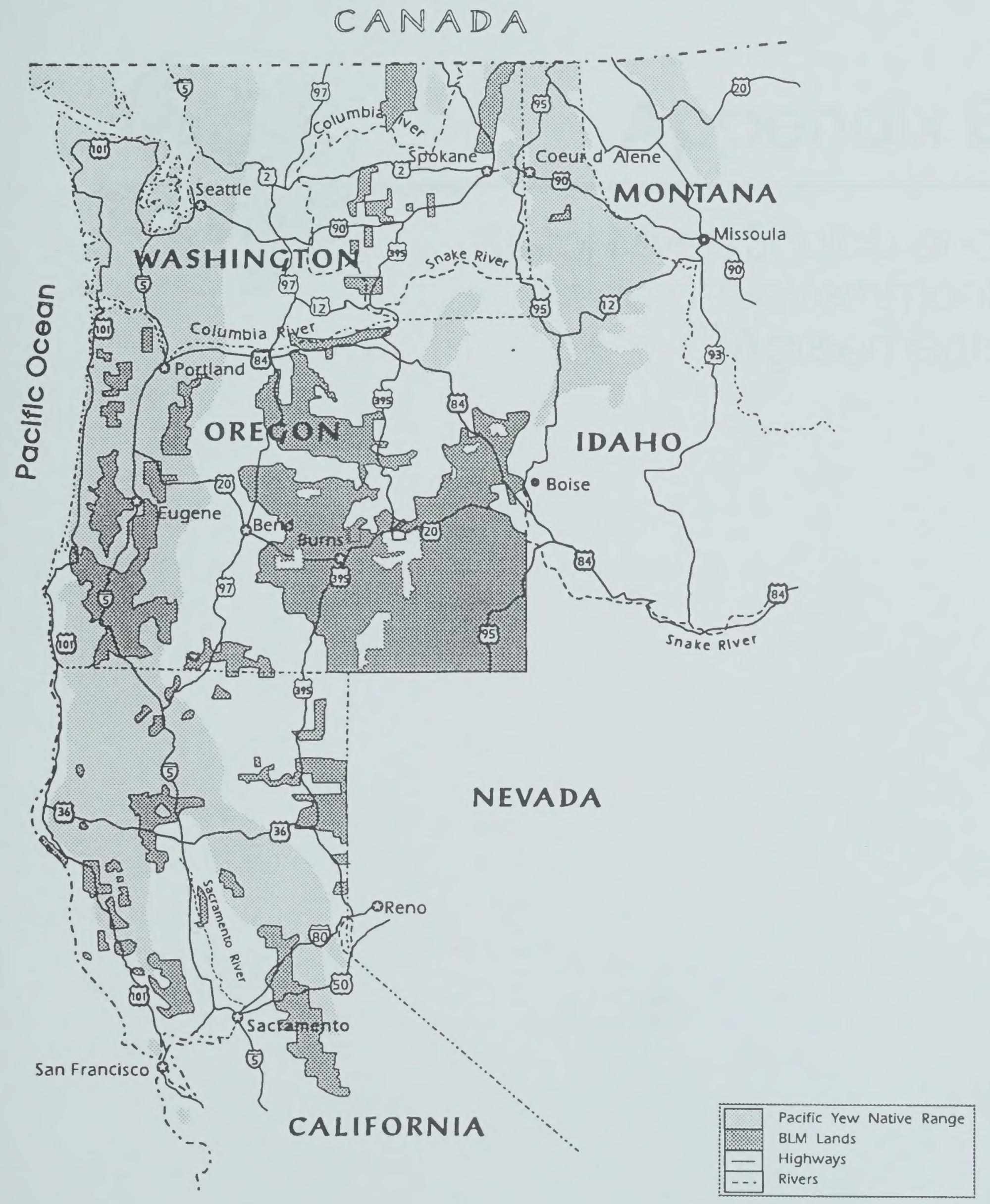

*Major blocks of land represented, most of the BLM land occurs in every other section in the major block of land). 



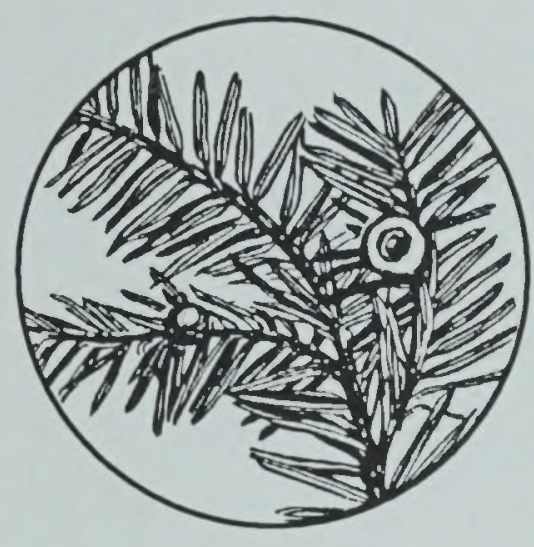

\section{Appendix E}

Bristol-Myers Squibb and Federal Government Agreements 


\section{Changes Made Since the Draft EIS}

Appendix E

Omitted the "Annual Pacific Yew Program Plans" for the Forest Service and the BLM, and added these to our process records. 


\section{Agreements}

This appendix is a compilation of the agreements forming the basis of the Pacific yew harvest program on Federal lands. In order of appearance it contains the following:

The Collaborative Research and Development

Agreement (CRADA) for The Clinical

Development of Taxol

The Memorandum of Understanding

The Cooperative Agreement between the United States Department of Agriculture Forest Service and Bristol-Myers Squibb Company

The Cooperative Agreement between the United States Department of the Interior Bureau of Land Management and Bristol-Myers Squibb Company ... 29-37

Statement of Dr. Bruce Chabner, Director, Division of Cancer Treatment National Cancer Institute Before the United States House of Representatives and several subcommittees, Hearing on H.R. 3836, The Pacific Yew Act of 1991. (Although this document is not an agreement, we have included it because it addresses many concerns people have about the agreements.) 



\section{COLLABORATIVE RESEARCH AND DEVELOPMENT AGREEMENT FOR \\ THE CLINICAL DEVELOPMENT OF TAXOL}

WHEREAs taxol, an investigational new drug derived from the bark of Taxus brevifolia ("taxus"), the Pacific Yew tree, has demonstrated promising antitumor activity in pre-clinical testing and clinical trials; and

WHEREAs the Division of Cancer Treatment, National

Cancer Institute ("NCI") has conducted pre-clinical testing and clinical trials of taxol and is seeking to enter into a collaborative research and development agreement ("CRADA") with a pharmaceutical company which has the facilities, experience and expertise necessary to develop taxol into an approved drug available to the public; and

WHEREAS NCI has determined, after reviewing the response to its invitation for CRADA development published in the Federal Register on August 1, 1989, that Bristol-Myers Squibb Company ("Bristol-Myers Squibb") is a pharmaceutical company that meets the published criteria for entering into a taxol CRADA; and

WHEREA8 NCI and Bristol-Myers Squibb (the "Parties") wish to collaborate in research on, and the development of, taxol as an antitumor agent, and to generate data necessary to obtain 
approval from the Food and Drug Administration ("FDA") to market taxol;

NOW THEREFORE, in consideration of the promises and undertakings described herein, NCI and Bristol-Myers Squibb agree as follows:

\section{JOINT STEERING COMMITTEE}

A. Promptly upon the execution of this CRADA, NCI and Bristol-Myers Squibb shall form a Joint steering Committee (the "Steering committee"). The steering committee will be responsible for the design, implementation, oversight and evaluation of clinical research and development subject to this CRADA; for determining the scope and magnitude of clinical trials necessary to explore taxol's clinical utility; for establishing the order and priority of clinical trials; and for other taxol clinical research and development activities under this CRADA as otherwise agreed to by the steering committee.

B. NCI and Bristol-Myers Squibb shall have equal voice in decisions of the steering committee. The initial composition of the steering Committee shall be five voting members on behalf of NCI and five voting members on behalf of Bristol-Myers Squibb. A steering Committee member representing Bristol-Myers Squibb will chair the steering committee. The membership of the steering Committee may be changed from time to time as mutually agreed by NCI and Bristol-Myers Squibb. 
c. In the event agreement cannot be reached by the Steering committee on an issue subject to this CRADA, the matter shall be referred to, and a decision will be made jointly by, Dr. Steven Carter of Bristol-Myers Squibb, and Dr. Bruce Chabner of NCI .

D. If the persons identified in Subparagraph $c$ of Paragraph 1 are unable to resolve a dispute within thirty (30) days after referral from the steering Committee, the Director National Institutes of Health shall propose a resolution. Nothing in this Paragraph shall preclude the Parties from pursuing any and all available administrative or judicial remedies.

E. The steering Committee shall meet within one month of the execution of this CRADA, and then regularly thereafter as appropriate.

F. The Parties shall report regularly to the steering Committee on the progress of the various clinical trials under their supervision, and on other research and drug development efforts subject to this CRADA.

G. At the first steering committee meeting, and at regular intervals thereafter, the Parties shall provide to each other (1) information about the quantity of taxol available for clinical research and other research purposes pursuant to this CRADA, together with relevant stability data; and (2) anticipated timelines for drug production and supply for activities subject to this CRADA. 
H. Attendance at steering Committee meetings shall be limited to members of the steering committee and invited participants as mutually agreed to by the Parties.

I. The steering Committee shall prepare, and the Parties shall approve, written summaries of each steering Committee meeting. These summaries shall include information about Steering Committee deliberations and describe issues addressed and decisions reached. Written materials created by the steering Committee shall be treated as described in subparagraph $\mathrm{J}$ of Paragraph 1.

J. Except as required by law and subject to Paragraph 15 of this CRADA, the Parties agree that any information or documents created or exchanged pertaining to the subject matter of this CRADA, all discussions and information exchanged at meetings of the steering Committee, and all written summaries of Steering Committee meetings shall be maintained as confidential to the Parties, and shall not be disclosed to any third-parties absent agreement by the steering committee.

\section{FINANCIAL AND BTAFFING CONTRIBUTIONS}

A. Although expenses and staffing are impossible to quantify at this time, Bristol-Myers Squibb anticipates committing direct expenses of [

] dollars in furtherance of its development of taxol, and anticipates committing a minimum of [ 
] staff years to taxol research and development

efforts.

B. NCI, in collaboration with Bristol-Myers Squibb, shall continue clinical development of taxol under NCI's extramural and intramural clinical research programs.

c. NCI will provide no funding to Bristol-Myers Squibb for collaborative research or development pursuant to this CRADA.

\section{EXI8TING IND}

NCI has filed an investigational new drug application ("IND"), IND No. 22,850, for taxol with FDA.

4. COMPLETED AND ONGOING CLINICAL TRIALS AND DATA 8UBJECT to THIS CRADA

A. NCI, directly and through its extramural research network ("extramural investigators"), has funded or conducted studies, or is funding or conducting studies, some of which 
support the registration of taxol. As to such taxol studies or data currently within NCI's control, NCI shall, subject to the right of publication afforded by Paragraph 15 of this CRADA, maintain these raw data as proprietary and confidential, and make them available exclusively to Bristol-Myers Squibb for use in obtaining approval for the commercial marketing of taxol. As to government-funded taxol data currently in the control of extramural investigators, NCI shall urge extramural investigators to cooperate exclusively with Bristol-Myers Squibb in providing raw data for use in obtaining regulatory approval for the commercial marketing of taxol. However, NCI's urging is not intended to constitute a term or condition for making an award to said extramural investigators.

B. Bristol-Myers Squibb shall provide formulated taxol product for ongoing studies as provided in Paragraph 11 of this CRADA.

\section{STUDIES AND DATA TO BE INITIATED PURSUANT TO THIS CRADA}

A. NCI and Bristol-Myers Squibb will collaborate on the design, oversight and implementation of clinical trials required for FDA approval for the commercialization of taxol. These studies will be selected and designed to be utilized in a New Drug Application ("NDA") to obtain FDA approval for the marketing of taxol for treatment of [ ]. NCI and Bristol-Myers Squibb will supply formulated taxol product for use in these clinical trials, as recommended and prioritized by the 
Steering Committee. It is anticipated, and the Parties will utilize best efforts to ensure, that an NDA [

$$
\text { ] will be filed within [ from the date }
$$

of the execution of this CRADA.

B. [

C. Bristol-Myers Squibb shall initiate any new preclinical studies Bristol-Myers Squibb determines are necessary for drug registration.

D. As soon as feasible, Bristol-Myers Squibb shall provide formulated taxol product for NCI intramural studies as approved by the steering Committee as well as the extramural trials outlined in subparagraph B of this Paragraph 5.

E. Subject to the right of publication afforded by Paragraph 15 of this CRADA, the Parties agree that all new studies and raw data developed pursuant to this Paragraph, and under their control, shall be maintained as proprietary and confidential. NCI shall make the raw data available exclusively 
to Bristol-Myers Squibb for use in obtaining regulatory approval for the commercial marketing of taxol. NCI shall indicate in all future contracts with extramural investigators for taxol research and in all intramural clinical research that such data shall be so maintained, and no future extramural contract for taxol research under this Paragraph 5 shall be executed absent such investigator's concurrence regarding confidentiality. With respect to future extramural research conducted under grants from NCI, NCI shall urge extramural investigators to cooperate exclusively with Bristol-Myers Squibb in providing raw data for use ir obtaining regulatory approval for the commercial marketing of taxol. However, NCI's urging is not intended to constitute a term or condition for making an award to said extramural investigators.

6. DATA COLLECTION

A. Bristol-Myers Squibb shall be responsible for collecting taxol-related pre-clinical and clinical data from investigators described in Paragraphs 4 and 5 of this CRADA.

B. In pursuing data collection efforts, Bristol-Myers Squibb shall provide funds to investigators as necessary and appropriate for all additional laboratory tests or clinical trials requested by Bristol-Myers Squibb, for data collection expenses, and for generation of case report forms.

c. It is understood that NCI will be permitted access to all data subject to this CRADA. 


\section{NEW DRUG APPLICATION}

A. Bristol-Myers Squibb shall prepare and submit an NDA to FDA as expeditiously as is feasible, when Bristol-Myers Squibb determines that such actions are justified by clinical results.

B. NCI shall cooperate with Bristol-Myers Squibb as necessary and appropriate in all aspects of the registration process.

\section{EXCHANGE OF TECHNICAL INFORMATION}

A. To the extent permitted by law, and subject to appropriate confidentiality protections, NCI shall, during the term of this CRADA, provide to Bristol-Myers Squibb all technical information in its possession, or acquired in the future, regarding taxol research and development.

\section{COMPLIANCE WITH HHS REGULATIONS}

Bristol-Myers Squibb agrees to comply with all appropriate Department of Health and Human Services regulations relating to Human Subject Use, all applicable U.S. Department of Agriculture regulations, and all Public Health Service policies relating to the use and care of laboratory animals.

\section{ADDITIONAL RESEARCH}

A. Bristol-Myers Squibb shall investigate and establish, as feasible and appropriate, alternative sources of taxol. These sources shall include [ 
B. NCI shall be free to sponsor additional basic research outside the scope of this CRADA. The research outside the scope of this CRADA includes studies of basic mechanisms of taxol action, taxol production, taxol derivatives and taxol analogues, and the use of taxol for other indications not added by amendment to this CRADA pursuant to Subparagraph B of Paragraph 5. However, NCI acknowledges Bristol-Myers Squibb's need to commercialize taxol as rapidly as possible in order to make the product widely available to the oncology community and to recover the investment made in taxol research so that ongoing taxol development can be adequately financed. NCI agrees to refrain from assisting any commercial party other than Bristol-Myers squibb for the commercialization of taxol during the term of this CRADA, and during any period thereafter in which Bristol-Myers Squibb is engaged in the commercial development and marketing of taxol, provided that this CRADA is not terminated under Subparagraphs B or C of Paragraph 17, and that public health needs are adequately served.

C. Bristol-Myers Squibb shall be free to sponsor additional clinical and pre-clinical research outside the scope of this CRADA. 
11. PROCB88ING AND 8UPPLY OF FORYOLATED TAXOL FOR CLINICAL TRIAL8 AND COKPAB8IONATB $08 B$

A. NCI shall transfer to Bristol-Myers Squibb Taxus bark collected pursuant to contract $\neq$ [

] for processing into formulated taxol product. Except as provided in Subparagraph $A$ of Paragraph 5, and in Subparagraph B of Paragraph 11, Bristol-Myers Squibb shall acquire and process all other quantities of bulk taxol needed to fulfill the formulated taxol requirements of this CRADA as feasible and appropriate.]

B. NCI and Bristol-Myers Squibb shall supply formulated taxol, as available from existing inventories, for clinical trials as prioritized by the steering committee.

C. Formulated taxol product shall be supplied pursuant to this Paragraph for all clinical trials to which NCI currently has committed (see Exhibit A) and for future clinical trials or other research as determined by the steering committee.

D. [

12. GROUP C

A. Group C drug distribution shall be initiated when the Steering Committee recommends, and NCI and Bristol-Myers Squibb mutually agree, that such action is justified by clinical results 
and feasible based on adequate drug supply. Drug for this use shall be provided [ ] to NCI by Bristol-Myers Squibb. B. The steering committee will determine the quantity of drug to be made available for Grnup $C$ distribution, and shall design and approve a clinical protocol to govern such distribution. In exercising these responsibilities, the steering Committee shall consider the need of the public, the availability of alternative therapies, the availability of formulated taxol product, and the need adequately to supply ongoing clinical trials.

13. COMQYERCIALIZATION OF TAXOL

A. [ 
B.

C. [

\section{INTELLECTUAL PROPERTY}

A. The Parties agree that if any patentable invention is conceived or reduced to practice in the performance of collaborative research under this CRADA by employees of NCI or BristolMyers Squibb, such invention shall be treated in accordance with the provisions of the NIH model CRADA, and accompanying NIH policy documents, attached as Exhibit D.

B. [ 


\section{PUBLICATION}

A. As is consistent with the Parties' obligation to maintain raw data described herein confidential and proprietary, the Parties may publicly disclose the results of their research. Before either Party submits a paper or abstract for publication or otherwise intends to publicly disclose information subject to this CRADA, the other Party shall be provided thirty (30) days to review the proposed publication or disclosure to assure that confidential and proprietary data is protected. The publication or other disclosure shall be delayed for up to thirty (30) additional days upon written request by either Party as necessary to preserve U.S. or foreign or other intellectual property rights. Nothing contained in Subparagraph $\mathrm{J}$ of Paragraph 1 of this CRADA shall prevent the timely publication of the results of clinical trials or pre-clinical research.

B. Except as to the obligations of extramural investigators to maintain raw data as confidential and proprietary to Bristol-Myers Squibb for use in obtaining regulatory approval for the commercial marketing of taxol as described in Paragraphs 4 and 5 of this CRADA, nothing contained herein shall restrict the rights of extramural investigators to 
publish the results of their research in accordance with applicable policies of NCI.

\section{ABSTRACT OF THE CRADA RESEARCH PLAN FOR PUBLIC RELEASE}

The following is an abstract of the CRADA Research Plan for public release:
The National Cancer Institute and Bristol- Myers Squibb Company will collaborate in the clinical development of taxol, a novel chemically defined compound which has shown promising antitumor activity in several clinical trials. Of particular interest is the $30 \%$ objective response rate observed in Phase II trials in patients with relapsed or refractory ovarian cancer, a disease general- ly considered resistant to chemotherapy. The National Cancer Institute and the Bristol- Myers Squibb Company will collaborate to obtain approval of taxol as a commercial anticancer agent for this indication and to evaluate its clinical utility in other human malignancies.

\section{TERMINATION}

A. This CRADA may be terminated at any time by mutual consent of the Parties.

B. Either Party may terminate this CRADA if the other Party breaches a material term or condition, and if the breach is not cured within a period of sixty $(60)$ days after written notice of breach is given to the other Party.

C. This CRADA may be terminated by Bristol-Myers squibb if, on the basis of reasonable evidence, Bristol-Myers Squibb determines that the further development of taxol pursuant to this CRADA is not commercially feasible. 
D. This CRADA may be terminated by NCI if, after providing Bristol-Myers Squibb sixty (60) days notice and a reasonable opportunity to cure, NCI determines, on the basis of reasonable evidence, that Bristol-Myers Squibb has failed to exercise best efforts in the commercialization of taxol.

E. In the event of termination of this CRADA, the disposition of the data, property, studies, and raw materials, including formulated taxol, and taxol to be formulated subject to this CRADA, shall be determined by the steering Committee. All raw materials to be transferred to NCI pursuant to this Subparagraph shall be provided at cost by Bristol-Myers Squibb.

\section{ENTIRE AGREEMENT}

A. This CRADA constitutes the entire agreement in respect of the subject matter hereof between the Parties, and supersedes all previous negotiations, commitments and/or agreements, whether written or oral. It may not be changed or modified in any manner, orally or otherwise, except by an instrument in writing signed by a duly authorized officer or representative of each of the Parties.

B. For ease of scientific review and reference, a Research Plan (Exhibit B) and a statement of Respective Contributions of the Parties (Exhibit C) are attached to this CRADA. These exhibits are abstracted from the provision of this CRADA, and the inclusion of these exhibits is not intended to 
alter the rights and obligations of the Parties as set forth in the text of this CRADA.

\section{NOTICES}

Any notices in writing and payments to be made under this CRADA will be deemed duly given and made if sent by courier or by certified or registered mail, postage prepaid. Communications between the Parties will be addressed to the following persons, or to such other persons as the parties may designate from time to time in writing:

To NCI:

(1) Director, Division of Cancer Treatment National Cancer Institute

Building 31, Room 3 A52 9000 Rockville Pike Bethesda, Maryland 20892

$$
\text { and }
$$

(2) Director, office of Technology Development

National Cancer Institute Building 31, Room 3A52 9000 Rockville Pike Bethesda, Maryland 20892

To Bristol-Myers Squibb: Vice President, Licensing

$$
\begin{aligned}
& \text { Bristol-Myers Squibb } \\
& \text { P.O. Box } 4000
\end{aligned}
$$

Princeton, New Jersey 08540 
By executing this CRADA, each of the undersigned represents and confirms that he is fully authorized to bind his identified company or entity to its terms.

\section{WAIVER}

The waiver by either Party of a breach of any provisions of this CRADA will not operate or be construed as a waiver of any subsequent breach.

\section{GOVERNING LAW}

The construction, validity, performance and effect of this CRADA shall be governed by Federal Law, as applied by the Federal Courts in the District of Columbia.

\section{EFFECTIVE DATE}

This CRADA shall be effective on the date last below signed.

IN WITNESS THEREOF, the Parties have caused this CRADA to be executed.

NATIONAL CANCER INSTITUTE

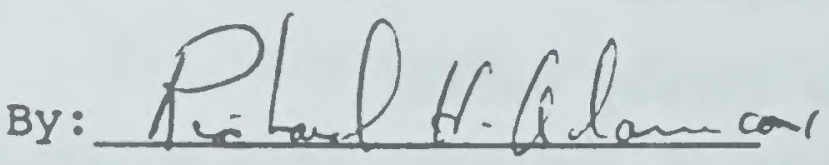

Title: Acting Deputy Director

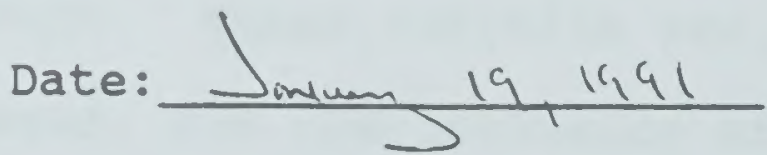

BRISTOL-MYERS SQUIBB COMPANY

By:

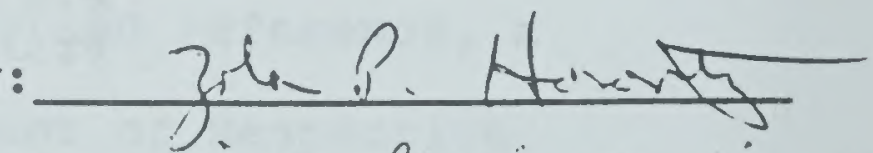
Title: Vice PRESIDENT, LICENiING

Date: $-2.3,1991$ 


\section{MEMORANDUM OF UNDERSTANDING}

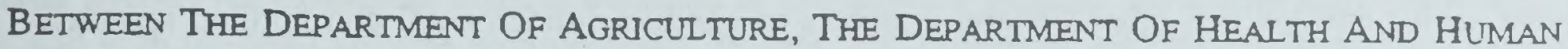
SERVICES, AND THE DEPARTMENT OF THE INTERIOR REGARDING THE EFFECTIVE USE OF NATURAL PRODUCTS WITH POTENTIAL FOR THE TREATMENT OF CANCER

WHEREAS, even though there are drugs available which provide some benefit in the treatment of ovarian cancer, each year approximately 12,000 women die of this disease.

WHEREAS, taxol is a plant-derived anticancer drug discovered through research supported by the National Cancer Institute. Currently, the only source of taxol approved for use in clinical mials is the bark of the Pacific yew tree, Taxus brevifolia.

WHEREAS, in clinical trials conducted under the sponsorship of the National Cancer Institute, taxol has demonstrated significant activity against recurrent ovarian cancer with a 30-35\% response rate in over 200 patients. Due to this high response rate, further research is in progress using taxol in combination with other drags against ovarian cancer and in the treatment of other major cancers such as breast, lung and colon, and such research is an emergency priority.

WHEREAS, there is a critical shortage of taxol at the present time. More than 25 kilograms of pure taxol will be required this year to meet the immediate needs of approximately 12,000 ovarian cancer patients, to maintain and expand the clinical trials of taxol, and to begin to meet the needs of patients who are not participating in these trials. To satisfy this year's demand for taxol a minimum of 750,000 pounds of bark from the Pacific yew tree is required, and needs for the future will continue to expand.

WHEREAS, Pacific yew grows in western forests from the southern tip of Alaska, through western Washington and Oregon, to central California; in moister portions of the Blue Mountains in eastern Washington and Oregon; and in the moister westem Rocky Mountains from southeastem British Columbia south to central Idaho and western Montana.

WHEREAS, the greatest concentration of existing Pacific yew is found on lands in the western United States managed by agencies within the Department of Agriculture and the Department of the Interior.

WHEREAS, the National Cancer Institute, an agency within the Department of Health and Human Services, pursuant to authority granted by the Federal Technology Transfer Act, 15 U.S.C. $\S$ $3710 \mathrm{a}$, initiated an open, competitive process to select a private entity in order to facilitate the clinical and commercial development of taxol. As a result of this competitive process, the National Cancer Institute entered into a Cooperative Research and Development Agreement (CRADA) designating Bristol-Myers Squibb Company as its partner in the development of taxol.

WHEREAS, the National Cancer Institute's designee under the CRADA is required to secure adequate supplies of taxol for continued development and commercialization of the drug, including support of necessary clinical trials and distribution of taxol for compassionate use. 
WHEREAS, the Secretary of Agriculture, pursuant to the National Agricultural Research, Extension, and Teaching Policy Act as amended, 7 U.S.C. $\S \S 3318,3819 \mathrm{e}$, may participate with private sector entities and other Federal agencies to conduct fundamental and applied research related to the development of new commercial products derived from natural plant materials for medical and other applications. Additionally, the Secretary of Agriculture under the Rangeland Renewable Resources Research Act of 1978, 16 U.S.C. §§ 1643(c), may enter into cooperative agreements with Federal and State governmental entiries as well as private agencies, and may receive money and other contributions to support the protection, management, and utilization of the Nation's renewable resources.

WHEREAS, the Secretary of Health and Human Services, pursuant to 42 U.S.C. $\S 241$ is authorized to encourage, cooperate with, and render assistance to other appropriate public authorities, scientific institutions, and scientists in the conduct of, and promote the coordination of, research, investigations, experiments, demonstrations, and studies relating to the causes, diagnosis, treatment, control, and prevention of physical and mental diseases and impairments of man.

WHEREAS, the Secretary of the Interior, pursuant to Section 307 of the Federal Land Policy and Management Act of 1976, 43 U.S.C. $\$ 1737$, may conduct investigations, studies and experiments, on his own initiative or in cooperation with others, involving the management, protection, development, acquisition and conveyance of public lands and may enter into cooperative agreements for these purposes, subject to applicable laws.

WHEREAS, nothing in this Memorandum shall be construed as obligating the agencies involved to expend, contract, or otherwise commit the United States to any payment of funds in excess of appropriations authorized by law.

WHEREAS, no member of, delegate to, or resident commissioner in Congress may receive any benefit arising from this Memorandum, other than a general benefit which may be conferred upon a corporation.

NOW THEREFORE, in consideration of the above premises the Secretary of Agriculture, the Secretary of Health and Human Services, and the Secretary of the Interior agree as follows:

\section{OBJECTTVES}

A. Due to the urgency of the research being conducted by the National Cancer Institute, and the pressing need for taxol to carry out that research, the parties to this Memorandum shall use their best efforts, consistent with applicable laws, to assist the National Cancer Institute's designee under the CRADA in obtaining the raw material needed to produce taxol in accordance with its obligations under the CRADA.

B. In recognition of the inestimable value of Pacific yew, the parties to this Memorandum agree that it is in the national interest to promote and encourage a comprehensive research strategy designed to address the ecology, silviculture, management, and long-term viability of the Pacific yew, and to seek renewable sources of the drug. 
$07 / 09 / 91$

$09: 44$

8202

4479161

WO TIMBER GMT.

R-6 TIMBER GMT

004

C. The parties to this Memorandum shall use their best efforts to ensure that the raw material needed for extracting taxol is obtained in compliance with all applicable environmental laws and with minimal adverse environmental impact, and otherwise reflects environmental concern for the long-term survival of the species.

D. Due to the critical need to obtain greater quantities of taxol of suitable quality for use in research and treatment of human cancer, the parties to this Memorandum shall use their best efforts to ensure that the available raw material needed for extracting taxol is directed to those institutions which: (1) have been duly designated as agents of the National Cancer Institute's designee under the CRADA, and (2) are capable of producing taxol for human use in accordance with the Food \& Drug Administration's Good Manufacturing Practices regulations. However, the parties to this Memorandum retain the right to make available, for research purposes, limited amounts of raw material to state and federal agencies, educational institutions, and other entities independent of the current ability of those entities to meet the Good Manufacturing Practices requirements.

II. INTERAGENCY COORDINATION

The parties to this Memorandum, recognizing the need to obtain greater quantities of tax al shall, to the extent practical, coordinate the activities of their respective agencies in the furtherance of the objectives set forth in this Memorandum. Nothing herein, however, is intended to alter, limit or expand the existing statutory authority of any of the parties to this Memorandum.

IN WITNESS WHEREOF, the parties hereto have executed this Agreement as of the last date written below.

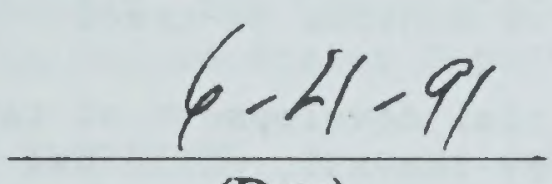

(Date)

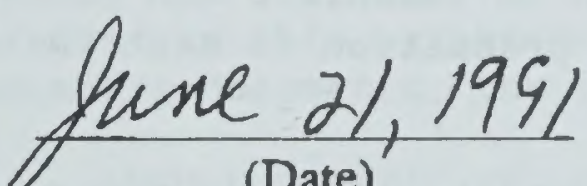

(Date)

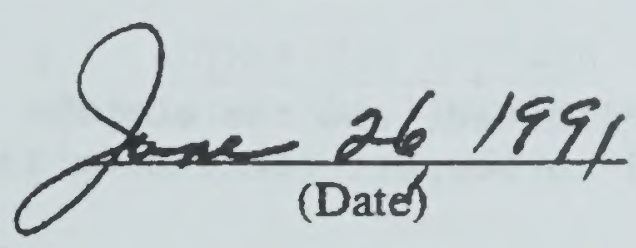

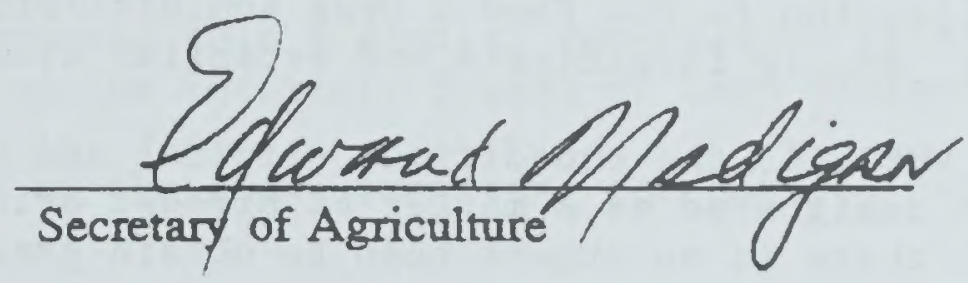

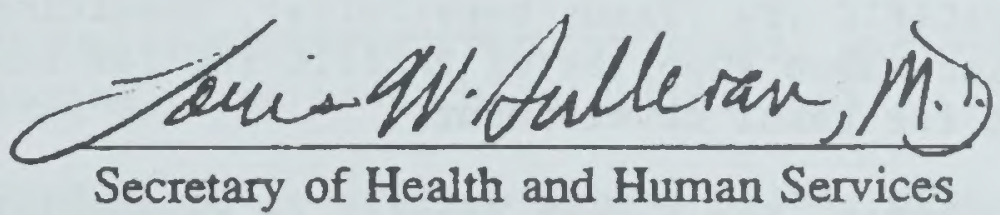

Secretary of Health and Human Services

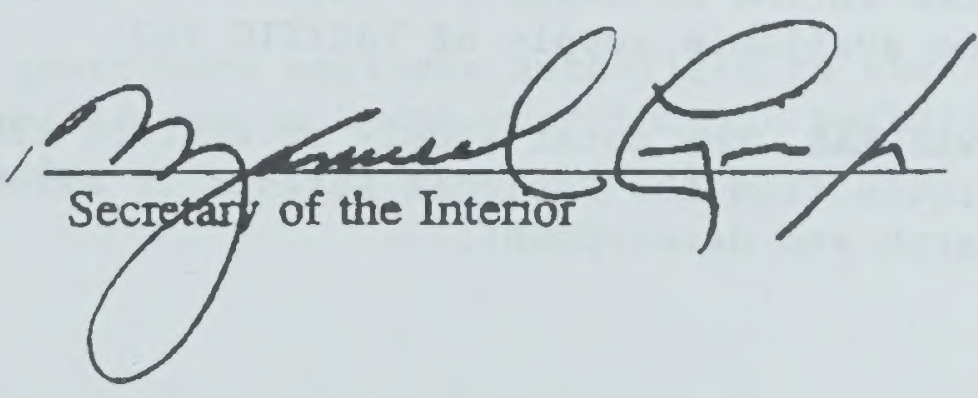




\section{COOPERATIVE AGREEMENT \\ BETWEEN THE \\ UNITED STATES DEPARTMENT OF AGRICULTURE \\ FOREST SERVICE \\ AND \\ BRISTOL-MYERS SQUIBB COMPANY}

THIS COOPERATIVE AGREEMENT is made and entered into by and between Bristol-Myers Squibb Company (hereinafter referred to as the Cooperator), and the Forest Service, U.S. Department of Agriculture (hereinafter referred to as the Forest Service).

WHEREAS, the Federal Technology Transfer Act, 15 U.S.C. 3710a, authorizes the federal government to enter into Cooperative Research and Development Agreements (CRADAs) with private entities for the development of new products and technologies;

WHEREAS, the Cooperator has entered into a CRADA with the National Cancer Institute (NCI), a component of the Department of Health and Human Services, in accordance with which Cooperator has been designated, through a competitive process, as NCI's sole commercial partner for purposes of the clinical and commercial development of taxol, an investigational new drug that has shown promising antitumor activity;

WHEREAS, the provisions of the NCI CRADA require the Cooperator to secure adequate supplies of taxol for continued development and commercialization of taxol, including support of necessary clinical trials and distribution of taxol through compassionate use and Group C mechanisms; to investigate the extraction, production and use of taxol; to prepare and submit a new drug application to the Food \& Drug Administration to obtain approval to market the drug; and to investigate and establish alternative sources of taxol;

WHEREAS, the expeditious clinical and commercial development of taxol has been designated as a matter of highest priority by the NCI, which has stated that there is an urgent need to obtain greater quantities of taxol;

WHEREAS, at the present time, taxol is derived primarily from the bark of the PACIFIC YEW (Taxus brevifolia), resulting in an immediate and pressing need for increased supplies of PACIFIC YEW for taxol production to meet the NCI's goals for taxol development;

WHEREAS, the Forest Service is responsible for the management and development of natural resources from the National Forests, including those located in the northwestern United States which contain a substantial portion of the available supply of PACIFIC YEW;

WHEREAS, the total supply of PACIFIC YEW is limited, and the supply available from the National Forests is essential to support continuing taxol research and development; 
WHEREAS, the Forest Service and the Cooperator recognize the need to:

a. Conduct inventories to determine the occurrence, quantity, and quality of PACIFIC YEW on federal lands, including the National Forests;

b. Conduct research on the ecology, silviculture, and management of PACIFIC YEW and associated species; and

c. Devcsup and implement management practices and guidelines that take into consideration environmental concerns relating to sound harvesting, regeneration, and sustainability of PACIFIC YEW.

WHEREAS, the Forest Service has limited financial resources available to carry out the necessary conservation, environmental, administrative and research activities commensurate with an increased level of utilization of the PACIFIC YEW for taxol research and development;

WHEREAS, the National Forest Management Act, 16 U.S.C. $472 a$ and implementing regulations set forth at 36 CFR 223.2(c) (entitled "Disposal of Timber for Administrative Use") authorize the Forest Service to dispose of trees, portions of trees, or other forest products needed for research; and

WHEREAS, the Forest Service, pursuant to the Rangeland Renewable Resources Research Act of 1978, 16 U.S.C. 1643(c); the National Agricultural Research, Extension, and Teaching Policy Act of 1977, 7 U.S.C. 3318; Pub. L. No. 101-512, 31 U.S.C. 6305; and 7 CFR 2.42 (c), may enter into cooperative agreements with private parties, and may receive money and other contributions from cooperators under such conditions as the Chief of the Forest Service may prescribe;

WHEREAS, the Cooperator has entered into a similar cooperative agreement with the United States Department of the Interior, Bureau of Land Management;

NOW THEREFORE, in consideration of the above premises, the parties hereto agree as follows:

\section{A. Definitions:}

As used in this agreement, ANNUAL PACIFIC YEW PROGRAM PLANS, and other implementing documents, the following terms have these definitions:

1. ANNUAL PACIFIC YEW PROGRAM PLANS - Written annual plans, prepared and mutually agreed upon by the Cooperator and the Forest Service, to implement this agreement through specified PROGRAM ELEMENTS.

2. AUTHORIZED OFFICER -. A government employee authorized to execute and administer the transfer of Pacific yew to Cooperator through permits, timber sales, or other contracts. 
3. PACIFIC YEW -. All portions of Taxus brevifolia, including but not limited to bark, twigs, needles and other foliage.

4. PROGRAM ELEMENTS - Detailed descriptions of research projects, environmental documents, PACIFIC YEW inventories, guidelines for the management and preservation of the PACIFIC YEW, harvesting goals and methods, funding requirements, and other related tasks and activities necessary to implement this agreement as mutually agreed upon in ANNUAL PACIFIC YEW PROGRAM PLANS.

B. The Forest Service shall:

1. After consultation with the Cooperator and the Bureau of Land Management, develop and implement a comprehensive program for conducting research on the ecology, silviculture, and management of PACIFIC YEW and associated species, for managing the utilization of PACIFIC YEW obtained from National Forest lands to support taxol research and development purposes in a manner which reflects environmental concern for the long-term survival of the species, and for assuring that all PACIFIC YEW harvested in accordance with this agreement are transferred to the Cooperator, subject to applicable laws, regulations, and forest plans for the affected area, and subject to approval by the responsible AUTHORIZED OFFICER. This program may include, but is not limited to, preparation of an inventory of PACIFIC YEW located on federal land, development of guidelines for the management and utilization of PACIFIC YEW in an environmentally sound manner, preparation of necessary environmental documents, execution of research on the ecology, silviculture, and management of the PACIFIC YEW and associated species, and other related activities, as agreed upon in ANNUAL PACIFIC YEW PROGRAM PLANS.

2. Designate contact persons and representatives to meet annually with appropriate representatives of the Cooperator and the Bureau of Land Management to discuss and agree upon coordinated ANNUAL PACIFIC YEW PROGRAM PLANS containing PROGRAM ELEMENTS, including detailed descriptions of research projects and funding levels, necessary to implement this agreement. On a quarterly basis, these representatives will review implementation of this agreement and ANNUAL PACIFIC YEW PROGRAM PLANS, discuss and resolve problems arising thereunder, and generally coordinate Yew Program activities.

3. Use its best efforts to develop ANNUAL PACIFIC YEW PROGRAM PLANS, PROGRAM ELEMENTS, and related cost estimates in accordance with general funding levels set forth in Schedule A. Although Cooperator agrees that it will not hold the Forest Service liable for damages for inaccurate cost and PACIFIC YEW volume estimates, the Cooperator reserves the right to refuse to fund individual PROGRAM ELEMENTS that exceed funding levels agreed upon in the ANNUAL PACIFIC YEW PROGRAM PLANS.

4. Furnish all personnel and administrative services needed to conduct research on the ecology, silviculture, and management of the PACIFIC YEW 
and associated species, to administer timber sale contracts and permits for harvesting of PACIFIC YEW, and to document, approve and implement this agreement and ANNUAL PACIFIC YEW PROGRAM PLANS agreed to by the Cooperator.

5. Provide prompt written notice to Cooperator of each permit, timber sale, or other contract under which PACIFIC YEW located on National Forest System lands will be available for transfer to Cooperator in accordance with this agreement.

6. Provide prompt written notice to Cooperator of all instances in which Cooperator or its agents, contractors, or subcontractors are failing to comply with the terms of this agreement, with the terms of applicable ANNUAL PACIFIC YEW PROGRAM PLANS and implementing permits, timber sales, or other contracts, and with applicable environmental protection standards as enunciated or required by the Forest Service.

7. Keep such records as are required for Forest Service approval and administration of this agreement, ANNUAL PACIFIC YEW PROGRAM PLANS, and all projects initiated in accordance with this agreement, and provide Cooperator with quarterly accountings of funds expended in accordance with this agreement and implementing documents.

8. Comply with provisions of Executive Order 12600, 52 Fed. Reg. 23,781 (1987), with respect to the confidential treatment of commercial and financial information contained in this agreement or obtained by the Forest Service in connection with this agreement.

\section{The Cooperator shall:}

1. Assure that all PACIFIC YEW obtained in accordance with this agreement will be utilized to the fullest extent practicable to produce taxol in accordance with the Cooperator's obligations under its CRADA with NCI. The disposition of any PACIFIC YEW which Cooperator cannot otherwise practicably utilize to produce taxol will be mutually agreed upon by the Cooperator and the Forest Service in ANNUAL PACIFIC YEW PROGRAM PLANS.

2. Accept or reject each transfer of PACIFIC YEW offered by the Forest Service within 30 days of receiving written notice of the availability of the applicable permit, timber sale, or other contract. Any offer of PACIFIC YEW which is rejected by Cooperator may subsequently be offered by the Forest Service to parties outside of this agreement.

3. Perform all administrative tasks required for the employment of agents, contractors, or subcontractors to carry out the terms of any permits, timber sales, or other contracts used to convey PACIFIC YEW to Cooperator in accordance with this agreement.

4. Furnish to the Forest Service the names, addresses and business locations of firms or individuals authorized to act as cooperator's agents, 
contractors, or subcontractors for purposes of procuring and harvesting PACIFIC YEW in accordance with this agreement.

5. Use its best efforts to assure that the Cooperator and its agents, contractors and subcontractors comply with all terms and conditions of permits, timber sales, or other contracts entered into for the purpose of conveying PACIFIC YEW to the Cooperator in accordance with this agreement.

6. Use its best efforts to assure that, with respect to all activities undertaken in accordance with this agreement, the Cooperator and its agents comply with all applicable environmental protection standards as enunciated or required by the Forest Service.

7. Designate contact persons and representatives to meet annually with appropriate Forest Service and Bureau of Land Management representatives to discuss and agree upon coordinated ANNUAL PACIFIC YEW PROGRAM PLANS containing PROGRAM ELEMENTS, including detailed descriptions of research projects and funding levels, necessary to implement this agreement. On a quarterly basis, these representatives shall review implementation of this agreement and ANNUAL PACIFIC YEW PROGRAM PLANS, discuss and resolve problems arising thereunder, and generally coordinate Yew Program activities.

8. Provide funds needed to implement ANNUAL PACIFIC YEW PROGRAM PLANS as agreed upon by the Cooperator.

9. Request no records or reports from the Forest Service, except those that may be needed for administration of permits, timber sale contracts or other related contracts used to implement this agreement.

10. Hold the Forest Service harmless from any and all claims, liability or damages incurred by the Cooperator, or the Cooperator's agents, contractors, or subcontractors in cunnection with activities authorized by this agreement.

11. Provide prompt notice to the Forest Service in the event that the Cooperator's CRADA with NCI is terminated or materially modified during the term of this agreement.

\section{It is mutually agreed that:}

1. Transfer of PACIFIC YEW will be accomplished in accordance with the terms of this agreement, ANNUAL PACIFIC YEW PROGRAM PLANS, and all implementing permits, timber sales, or other contracts negotiated between the Forest Service and the Cooperator.

2. Transfer of PACIFIC YEW to persons or entities other than Cooperator will be limited, in each permit, timber sale, or other contract, to de minimis amounts to be specified in ANNUAL PACIFIC YEW PROGRAM PLANS developed pursuant to this agreement; 
3. The Forest Service retains the right to make PACIFIC YEW available to state and federal agencies, educational institutions, and other entities in de minimis amounts to be specified in ANNUAL PACIFIC YEW PROGRAM PLANS developed pursuant to this agreement.

4. Research conducted under this agreement may include study of the ecology, silviculture, and management of the PACIFIC YEW and associated species, preparation of an inventory of the species located on federal land, analysis of environmentally sound harvesting methods, and related activities, as approved by Cooperator.

5. Research findings on the ecology, silviculture, and management of PACIFIC YEW and associated species will be shared with Cooperator, but will remain the property of the Federal Government. These findings may be published at the discretion of the Forest Service.

6. The parties will coordinate press releases and other public statements concerning this agreement, ANNUAL PACIFIC YEW PROGRAM PLANS and implementing documents.

7. ANNUAL PACIFIC YEW PROGRAM PLANS and implementing permits, timber sales, and other contracts shall be treated as subordinate to, and shall not take precedence over, the rights and obligations established by this agreement.

8. To the extent practicable, this agreement shall be implemented and construed in a manner consistent with a similar cooperative agreement between the Cooperator and the Department of Interior, Bureau of Land Management.

9. Nothing in this agreement shall be construed as obligating the Forest Service to expend, contract, or otherwise commit the United States to future payment of funds in excess of appropriations authorized by law

10. Either party may terminate this agreement by providing written notice at least 90 days prior to the date of intended termination.

11. Notwithstanding the termination provision in paragraph D. 10 of this agreement, the Forest Service may at any time suspend or terminate harvesting of PACIFIC YEW pursuant to this agreement, in whole or in part, to comply with any court order, administrative decision, statute, or regulation, or to prevent serious environmental harm as determined by the Forest Service.

12. In the event this agreement is suspended or terminated, such suspension or termination shall be without compensation to the non-terminating party, except that any of Cooperator's funds on deposit with the Forest Service will remain available to cover expenses rising out of, or incident to, work initiated prior to the date of such suspension or termination. After such work is completed, any of Cooperator's remaining 
funds deposited with the Forest Service shall be returned to the Cooperator within 30 days.

13. Notice required by this agreement shall be provided in writing to the following persons:

For the Forest Service:

For the Cooperator:

14. This agreement may not be orally modified. Amendments to this agreement are valid only if they are in writing and signed by both the Cooperator and the Forest Service.

15. The duration of this agreement shall be five years from the date of execution, subject to the renewal of this agreement for additional periods of one year as mutually agreed upon by the parties.

16. Unless terminated in writing, this agreement will remain in force until the expiration date.

17. Disputes arising under this agreement which cannot be resolved by the representatives identified in paragraphs B. 2 and $C .7$ shall be referred to the two signatories of this agreement for resolution.

IN WITNESS HHEREOF, the parties hereto have executed this Agreement as of the last date written below.
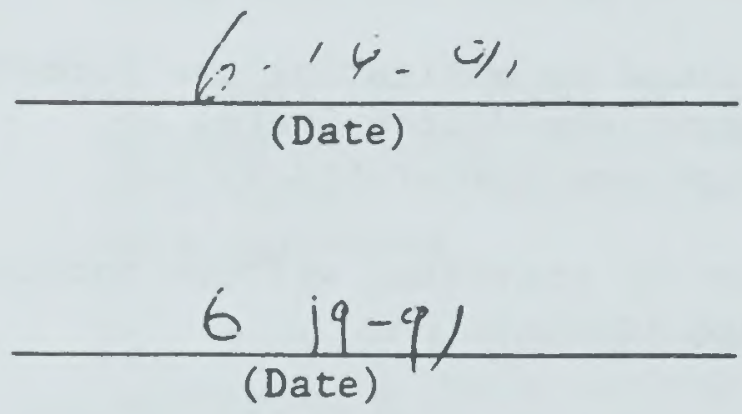
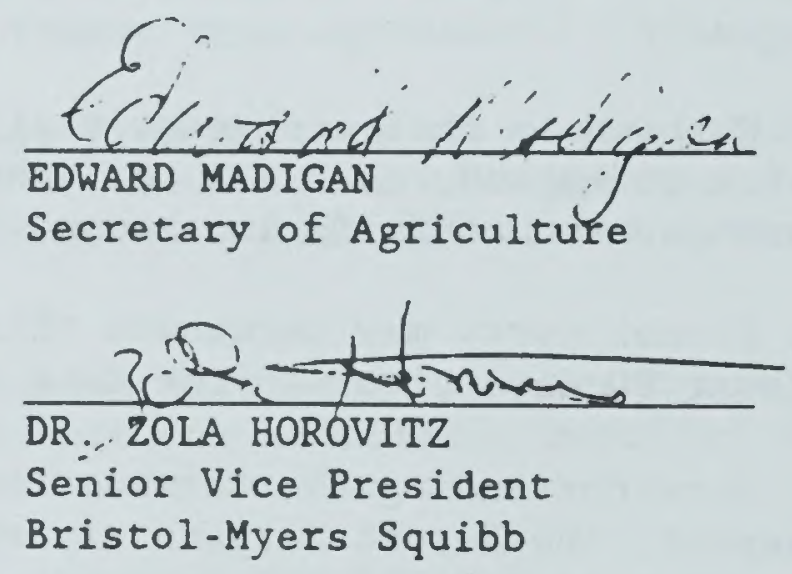


\section{COOPERATIVE AGREEMENT \\ BETWEEN THE \\ ONITED STATES DEPARTMENT OF THE INTERIOR \\ BUREAU OF LAND MANAGEMENT \\ AND \\ BRISTOL-MYERS SQUIBB COMPANY}

THIS COOPERATIVE AGREEMENT is made and entered into by and between Bristol-Myers Squibb Company (hereinafter referred to as the Cooperator), the Bureau of Land Management and the U.S. Department of the Interior (hereinafter referred to as the Bureau of Land Management).

WHEREAS, the Federal Technology Transfer Act, 15 U.S.C. $\S 3710 a$, authorizes the federal government to enter into Cooperative Research and Development Agreements (CRADAs) with private entities for the development of new products and technologies;

WHEREAS, the cooperator has entered into a CRADA with the National Cancer Institute (NCI), a component of the Department of Health and Human Services, in accordance with which cooperator has been designated, through a competitive process, as NCI's sole commercial partner for purposes of the clinical and commercial development of taxol, an investigational new drug that has shown promising antitumor activity;

WHEREAS, the provisions of the NCI CRADA require the cooperator to secure adequate supplies of taxol for continued development and commercialization of taxol, including support of necessary clinical trials and supply of taxol through compassionate use distribution channels; to investigate the extraction, production and use of taxol; to prepare and submit a new drug application to the Food \& Drug Administration to obtain approval to market the drug; and to investigate and establish alternative sources of taxol;

WHEREAS, the expeditious clinical and commercial development of taxol has been designated as a matter of highest priority by the NCI, which has stated that there is an urgent need to obtain greater quantities of taxol;

אHEREAS, at the present time, taxol is derived primarily from the bark of the PACIFIC YEW (Taxus brevifolia), resulting in an immediate and pressing need for increased supplies of PACIFIC YEW for taxol production to meet the NCI's goals for taxol development;

WHEREAS, the Bureau of Land Management is responsible for the management and development of natural resources on public lands, including forests located in the northwestern United 
States which contain a substantial portion of the available supply of PACIFIC YEW;

WHEREAS, the total supply of PACIFIC YEW is limited, and the supply available from Bureau of Land Management administered public lands is essential to support continuing taxol research and development;

WHEREAs, the Bureau of Land Management and the Cooperator recognize the need to:

a. Conduct inventories to determine the occurrence, quantity, and quality of PACIFIC YEW on public lands;

b. Conduct research on the ecology, silviculture, and management of PACIFIC YEW and associated species; and

c. Develop and implement management practices and guidelines that take into consideration environmental concerns relating to sound harvesting, regeneration, and sustainability of PACIFIC YEW.

WHEREAS, the Bureau of Land Management has limited financial resources available to carry out the necessary conservation, environmental, administrative and research activities commensurate with an increased level of utilization of the PACIFIC YEW for taxol research and development;

WHEREAS, Section 307 of the Federal Land Policy and Management Act of 1976,43 U.S.C. $\$ 1737$, provides that the secretary of the Interior may conduct investigations, studies and experiments, on his own initiative or in cooperation with others, involving the management, protection, development, acquisition and conveyance of public lands and may enter into cooperative agreements for these purposes, subject to applicable laws;

WHEREAS, the Cooperator has entered into a similar cooperative agreement with the Forest Service, United States Department of Agriculture:

NOW THEREFORE, in consideration of the above premises, the parties hereto agree as follows: 
As used in this agreement, ANNUAL PACIFIC YEW PROGRAM PLANS, and other implementing documents, the following terms have these definitions:

1. ANNUAL PACIFIC YEW PROGRAM PLANS -- Written annual

plans, prepared and mutually agreed upon by the

Cooperator and the Bureau of Land Management, to

implement this agreement through specified PROGRAM ELEMENTS.

2. AUTHORIZED OFFICER - - A government employee authorized to execute and administer the transfer of Pacific yew to cooperator through permits, timber sales, or other contracts.

3. PACIFIC YEW -- All portions of Taxus brevifolia, including but not limited to bark, twigs, needles and other foliage.

4. PROGRAM ELEMENTS -- Detailed descriptions of research projects, environmental documents, PACIFIC YEW inventories, guidelines for the management and preservation of the PACIFIC YEW, harvesting goals and methods, funding requirements, and other related tasks and activities necessary to implement this agreement as mutually agreed upon in ANNUAL PACIFIC YEW PROGRAM PLANS.

\section{B. The Bureau of Land Management shall:}

1. After consultation with the cooperator and the Forest Service, develop and implement a comprehensive program for conducting research on the ecology, silviculture, and management of PACIFIC YEW and associated species, for managing the utilization of PACIFIC YEW obtained from public lands to support taxol research and development purposes in a manner which reflects environmental concern for the longterm survival of the species, and for assuring that PACIFIC YEW harvested in accordance with this agreement are transferred to the cooperator, subject to applicable laws, regulations, and forest plans for the affected area, and subject to approval by the responsible AUTHORIZED OFFICER. This program may include, but is not limited to, preparation of an inventory of PACIFIC YEW located on public land, development of guidelines for the management and utilization of PACIFIC YEW in an environmentally sound manner,

preparation of necessary environmental documents, execution of appropriate transfer documents, execution of research on the ecology, silviculture, and management of the PACIFIC YEW 
and associated species, and other related activities, as agreed upon in ANNUAL PACIFIC YEW PROGRAM PLANS.

2. Designate contact persons and representatives to meet annually with appropriate representatives of the cooperator and the Forest Service to discuss and agree upon coordinated ANNUAL PACIFIC YEW PROGRAM PLANS containing PROGRAM ELEMENTS, including detailed descriptions of research projects and funding levels, necessary to implement this agreement. On a quarterly basis, these representatives will review implementation of this agreement and ANNUAL PACIFIC YEW PROGRAM PLANS, discuss and resolve problems arising thereunder, and generally coordinate Yew Program activities.

3. Use its best efforts to develop ANNUAL PACIFIC YEW PROGRAM PLANS, PROGRAM ELEMENTS, and related cost estimates in accordance with general funding levels set forth in Schedule A. Although Cooperator agrees that it will not hold the Bureau of Land Management liable for damages for inaccurate cost and PACIFIC YEW volume estimates, the cooperator reserves the right to refuse to fund individual PROGRAM ELEMENTS that exceed funding levels agreed upon in the ANNUAL PACIFIC YEW PROGRAM PLANS.

4. Furnish all personnel and administrative services needed to conduct research on the ecology, silviculture, and management of the PACIFIC YEW and associated species, to administer timber sale contracts and permits for harvesting of PACIFIC YEW, and to document, approve and implement this agreement and ANNUAL PACIFIC YEW PROGRAM PLANS agreed to bY the Cooperator.

5. Provide prompt written notice to cooperator of each permit, timber sale, or other contract under which PACIFIC YEW located on public lands will be available for transfer to cooperator in accordance with this agreement.

6. Provide prompt written notice to cooperator of all instances in which cooperator or its agents, contractors, or subcontractors are failing to comply with the terms of this agreement, with the terms of applicable ANNUAL PACIFIC YEW PROGRAM PLANS and implementing permits, timber sale contracts, or other contracts, and with applicable environmental protection standards as enunciated or required by the Bureau of Land Management.

7. Keep such records as are required for Bureau of Land Management approval and administration of this agreement, ANNUAL PACIFIC YEW PROGRAM PLANS, and all projects initiated in accordance with this agreement, and provide cooperator 
with quarterly accountings of funds expended in accordance with this agreement and implementing documents.

8. Comply with provisions of Executive order 12600,52 Fed. Reg. 23,781 (1987), with respect to the confidential treatment of commercial and financial information contained in this agreement or obtained by the Bureau of Land Management in connection with this agreement.

\section{The Cooperator shall:}

1. Assure that all PACIFIC YEW obtained in accordance with this agreement will be utilized to the fullest extent practicable to produce taxol in accordance with the cooperator's obligations under its CRADA with NCI. The disposition of any PACIFIC YEW which cooperator cannot otherwise practicably utilize to produce taxol will be mutually agreed upon by the cooperator and the Bureau of Land Management in ANNUAL PACIFIC YEW PROGRAM PLANS.

2. Accept or reject each transfer of PACIFIC YEW offered by the Bureau of Land Management within 30 days of receiving written notice of the availability of the applicable permit, timber sale contract, or other contract. Any offer of PACIFIC YEW which is rejected by Cooperator may subsequently be offered by the Bureau of Land Management to parties outside of this agreement.

3. Perform all administrative tasks required for the employment of agents, contractors, or subcontractors to carry out the terms of any permits, timber sales, or other contracts used to convey PACIFIC YEW to cooperator in accordance with this agreement.

4. Furnish to the Bureau of Land Management the names, addresses and business locations of firms or individuals authorized to act as cooperator's agents, contractors, or subcontractors for purposes of procuring and harvesting PACIFIC YEW in accordance with this agreement.

5. Use its best efforts to assure that the cooperator and its agents, contractors and subcontractors comply with all terms and conditions of permits, timber sale contracts, or other contracts entered into for the purpose of conveying PACIFIC YEW to the cooperator in accordance with this agreement.

6. Use its best efforts to assure that, with respect to all activities undertaken in accordance with this agreement, the cooperator and its agents comply with all applicable 
environmental protection standards as enunciated or required by the Bureau of Land Management.

7. Designate contact persons and representatives to meet annually with appropriate Forest service and Bureau of Land Management representatives to discuss and agree upon coordinated ANNUAL PACIFIC YEW PROGRAM PLANS containing PROGRAM ELEMENTS, including detailed descriptions of research projects and funding levels, necessary to implement this agreement. On a quarterly basis, these representatives shall review

implementation of this agreement and ANNUAL PACIFIC YEW PROGRAM PLANS, discuss and resolve problems arising thereunder, and generally coordinate Yew Program activities.

8. Provide funds needed to implement ANNUAL PACIFIC YEW PROGRAM PLANS as agreed upon by the cooperator.

9. Request no records or reports from the Bureau of Land Management, except those that may be needed for administration of permits, timber sale contracts or other related contracts used to implement this agreement.

10. Hold the Bureau of Land Management harmless from any and all claims, liability or damages incurred by the cooperator, or the cooperator's agents, contractors, or subcontractors in connection with activities authorized by this agreement.

11. Provide prompt notice to the Bureau of Land Management in the event that the cooperator's CRADA with NCI is terminated or materially modified during the term of this agreement.

12. Not advertise this agreement or any contract or transaction executed hereunder in such a manner as to state or imply that the Bureau of Land Management endorses a product, project, or commercial line of endeavor.

D. It is mutually agreed that:

1. Transfer of PACIFIC YEW to the cooperator will be accomplished in accordance with the terms of this agreement, ANNUAL PACIFIC YEW PROGRAM PLANS, and all implementing permits, timber sale contracts, or other contracts negotiated between the Bureau of Land Management and the cooperator.

2. Transfer of PACIFIC YEW to persons or entities other than Cooperator will be limited, in each permit, timber 
sale, or other contract, to de minimis amounts to be specified in ANNUAL PACIFIC YEW PROGRAM PLANS developed pursuant to this agreement:

3. The Bureau of Land Management retains the right to make PACIFIC YEW available to state and federal agencies, educational institutions, and other entities in de minimis amounts to be specified in ANNUAL PACIFIC YEW PROGRAM PLANS developed pursuant to this agreement.

4. Research conducted under this agreement may include study of the ecology, silviculture, and management of the PACIFIC YEW and associated species, preparation of an inventory of the species located on public lands, analysis of environmentally sound harvesting methods, and related activities, as agreed upon in ANNUAL PACIFIC YEW PROGRAM PLANS.

5. Research findings on the ecology, silviculture, and management of the PACIFIC YEW and associated species, the inventory of the species located on public lands, analysis of environmentally sound harvesting methods, and related activities will be shared with the Cooperator, but will remain the property of the Federal Government. These findings may be published at the discretion of the Bureau of Land Management.

6. The Cooperator will submit to the Bureau of Land Management for approval prior to distribution all proposed press releases referring to this agreement, the Bureau of Land Management or the Department of the Interior, or the title of any employee thereof. The Bureau of Land Management will coordinate press releases and other public statements concerning this agreement, ANNUAL PACIFIC YEW PROGRAM PLANS, and implementing documents with the Cooperator.

7. In the event of a conflict between this agreement and any element of the ANNUAL PACIFIC YEW PROGRAM PLANS, implementing permits, contracts for the sale of yew or other contracts contemplated and authorized by this agreement, this agreement shall control.

8. To the extent practicable, this agreement shall be implemented and construed in a manner consistent with a similar cooperative agreement between the cooperator and the Forest Service, Department of Agriculture.

9. Nothing in this agreement shall be construed as obligating the Bureau of Land Management to expend, contract, or otherwise commit the United states to future 
payment of funds in excess of appropriations authorized by law.

10. Either party may terminate this agreement by providing written notice at least 90 days prior to the date of intended termination.

11. Notwithstanding the termination provision in paragraph D. 10 of this agreement, the Bureau of Land Management may at any time suspend or terminate harvesting of PACIFIC YEW pursuant to this agreement, in whole or in part, to comply with any court order, administrative decision, statute, or regulation, or to prevent serious environmental harm as determined by the Bureau of Land Management.

12. In the event this agreement is suspended or terminated, such suspension or termination shall be without compensation to the non-terminating party, except that any of cooperator's funds on deposit with the Bureau of Land Management will remain available to cover expenses rising out of, or incident to, work initiated prior to the date of such suspension or termination. After such work is completed, any of cooperator's remaining funds deposited with the Bureau of Land Management shall be returned to the cooperator within 30 days.

13. Notice required by this agreement shall be provided in writing to the following persons:

Chief of Forestry

Bureau of Land Management

U.S. Department of the Interior

1849 C Street, N.W.

washington, D.C. 20240

For the Cooperator:

\author{
M. Dianne DeFuria \\ Director, Licensing \\ Bristol-Myers Squibb \\ Route 206 \& Province Line Road \\ Princeton, New Jersey 08540
}

14. This agreement may not be orally modified. Amendments to this agreement are valid only if they are in writing and signed by both the cooperator and the Bureau of Land Management.

15. The duration of this agreement shall be five years from the date of execution, subject to the renewal of this agreement for additional periods of one year as mutually agreed upon by the parties. 
16. Unless terminated in writing, this agreement will remain in force until the expiration date.

17. Disputes arising under this agreement which cannot be resolved by the representatives identified in paragraphs B. 2 and C. 7 shall be referred to the two signatories of this agreement for resolution.

18. No member of, delegate to, of resident commissioner in Congress shall be admitted to any share or part of this agreement, or to any benefit that may arise therefrom, but this provision hall not be construed to extend to this agreement if made with corporation for its general benefit.

IN TITHEs WHERE Or, the parties hereto have executed this Agreement as of the last date written below.
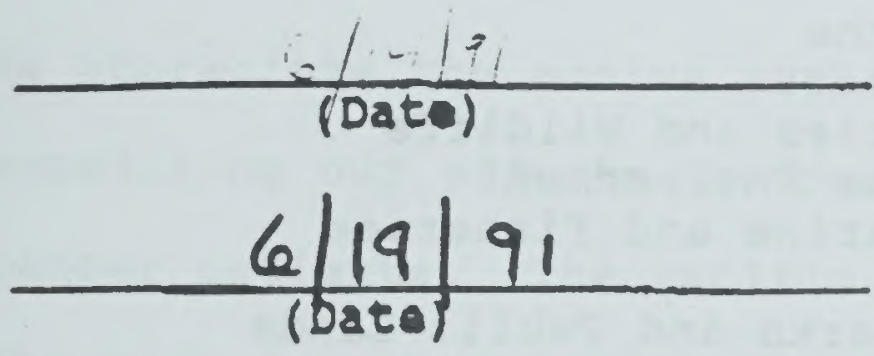
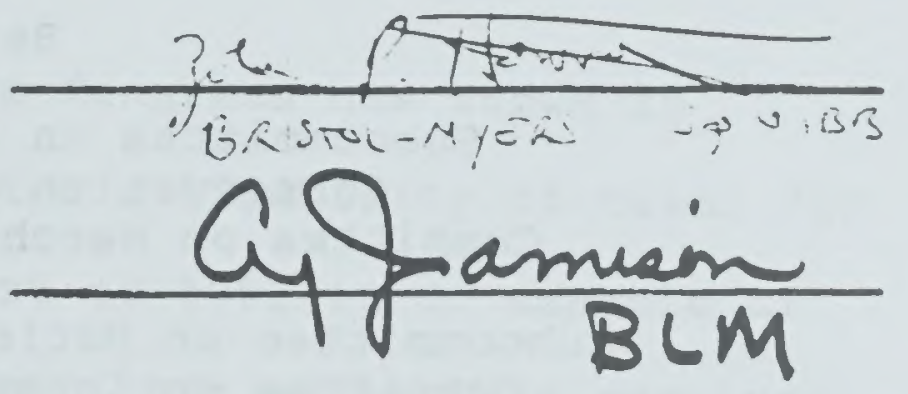


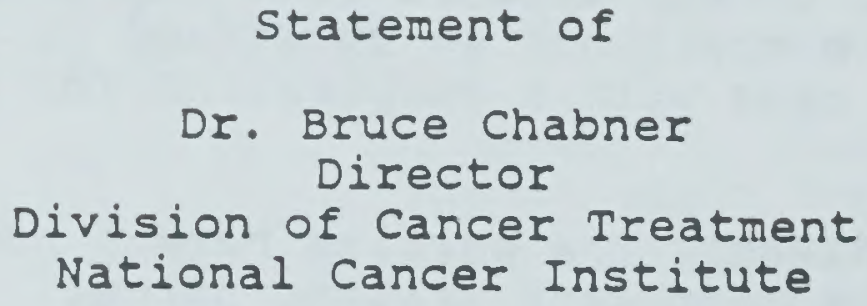

Before the

Subcommittee on Fisheries and Wildlife

Conservation and the Environment

Committee on Merchant Marine and Fisheries

Subcommittee on National Parks and Public Lands

Committee on Interior and Insular Affairs

Subcommittee on Forests, Family Farms, and Energy Comnittee on Agriculture

United States House of Representatives

Hearing on

H.R. 3836, The Pacific Yew Act of 1991

March 4, 1992 
Mr. Chairman and members of the subcommittees, thank you for inviting we to testify before you today regarding the drug taxol.

I am Dr. Bruce Chabner, Director of the Division of Cancer Treatment at the National Cancer Institute. I am accompanied today by Mr. Reid Adler, Director of the office of Technology Transfer at the National Institutes of Health.

I am pleased to have the opportunity to bring you up to date on the development of this important anticancer agent.

We appreciate the active support the congress has shown in expediting our efforts to increase the availability of taxol for cancer patients. The Pacific Yew Act of 1991 is an example of the high level of interest and support this effort has received from Congress; however, as its provisions do not bear directly on the programs and activities of the Department of Health and Human Services, we defer to our sister agencies to take a position on the bill.

Since many of the effective anticancer agents now in use are derived from natural products, we currently focus our discovery efforts on this vast and mostly untapped source of potentially very important agents.

We test extracts of natural products from plant and animal sources in screening systems that use panels of human tumor cell 
lines and select active extracts for further testing, chemical characterization, and clinical development. Because the plant or animal sources for these compounds frequently may be in limited supply or even endangered because of expansion of urbanization and destruction of habitat, our steadfast policy has been to protect the interests and ecology of the countries and communities that provide samples for these efforts. One year ago, we sponsored an international conference to define measures that will protect and preserve biodiversity in the environment. The result of that meeting has been a joint effort by the National Science Foundation, the state Department, and the NCI to support an environmentally sound program to identify pharmaceuticals from plant and animal species in developing countries.

One of the most promising natural products to be discovered through the NCI screening and development process is taxol. Taxol was originally isolated in 1971 from the bark of Taxus brevifolia, although subsequently we have found that it is present in the bark and needles of a variety of taxus species. Although taxol showed minimal activity in initial preclinical testing, it was later demonstrated to have a unique biochemical mechanism of action and a high degree of activity in selected non-human test systems. At each step, significant problems of production, supply, formulation, and clinical toxicity hampered its development. In 1988 activity against ovarian cancer was first observed, and in subsequent trials the drug produced 
response rates of about 30 percent in patients who had failed standard therapy, with some of these responses lasting more than one year.

Taxol has also demonstrated significant activity against breast cancer and is being tested for activity against several other types of cancer. This is a promising therapy for many thousands of cancer patients and its development is a very high priority for NCI. Unfortunately, as you know, the drug has been in critically short supply, but due to the combined efforts of NCI, Bristol-Myers Squibb, the Bureau of Land Management, and the Forest Service we have made significant progress.

currently the only reliable source of taxol for use in patients is an extract from the bark of the Pacific Yew tree, a tree native to the old growth forests of the Pacific Northwest. The concentration of taxol in each tree is very small, and about three trees are required to produce sufficient amounts of taxol to treat a single patient.

The combined potential population of patients with breast and ovarian cancer who may be candidates for treatment with taxol is approximately 50,000 persons per year, a number far in excess of the 500 patients per year receiving the drug in clinical trials before the cooperative efforts began. This year we will be able to treat at least 8 - 10,000 patients with the available supply 
of taxol produced from bark harvested in 1991 . This is a direct result of the cooperation between several federal agencies and the private sector.

our supplies are adequate to support several of our highest priority studies, but additional meritorious research could be initiated if the supplies were larger. It is impossible for me to predict what the supply situation will be at the time of drug approval, since this will depend on a number of factors beyond our control.

Since the passage of the Stevenson-Wydler Technology Innovation Act of 1980 and the Federal Technology Transfer Act of 1986, it is a national policy to transfer federally-owned or originated technology to the private sector whenever appropriate. The Act also encouraged, as a national policy, joint research and development projects between government laboratories and industry. Indeed, these are duties of each laboratory.

NCI has followed the policy of seeking partners in private industry to commercialize its discoveries and inventions. In order to assure the further development and eventual marketing of taxol, in $1990 \mathrm{NCI}$ entered into a Cooperative Research and Development Agreement (CRADA) with a pharmaceutical company, Bristol-Myers Squibb (BMS). 
The purpose of this CRADA is to expedite the development of taxol as an antitumor agent, and to generate data necessary to obtain FDA approval for this compound. The CRADA between NCI and BMS does not address the issue of compensation for utilization of yew trees. This matter has been addressed by the Forest Service and the Bureau of Land Management in their agreements with BMS.

The CRADA was awarded to BMS following a full and open competition, including publication in the Federal Register, and a thorough scientific review by government scientists of the four separate proposals submitted. Under the CRADA, BMS has undertaken the complicated and expensive production of taxol and has cooperated with NCI in performing the necessary clinical trials. To date, BMS has made impressive progress and has exceeded the goals set forth under the CRADA. In exchange, NCI has agreed to provide BMS with access to its clinical and preclinical data on an exclusive basis solely for use in obtaining approval for the commercial marketing of taxol. Further, NCI has reserved the right to publish the results of its studies with taxol.

Because the very first developmental work occurred and was published many years ago (indeed prior to the enactment of the Federal Technology Transfer Act), there currently is no government-owned patent protection for this agent. The CRADA, however, is an extremely useful mechanism through which to link 
NCI's continuing laboratory and clinical research interests in taxol with BMS's product development efforts. Under the CRADA, NCI and BMS scientists have collaborated on the design, oversight and implementation of clinical trials required for FDA approval and on additional research and development of taxol. This collaboration has accelerated the pace of development of taxol and will allow its introduction into the standard arsenal of approved anticancer agents in the near future, assuming that taxol continues to be found safe and effective.

The NCI does not have the capacity to develop and market taxol as a prescription drug on its own, nor does any other government agency. Nor has NCI the legal authority to market drugs. While BMS has obtained orphan drug status from the FDA for taxol in ovarian cancer patients, other companies are free to pursue the development of taxol for other diseases. In addition, NCI, through its own research and development programs, is vigorously attempting to develop other taxol-like drugs. These would be available through patent licensing on a competitive basis to all pharmaceutical companies.

In recognition of the need to establish a fair and reasonable price for taxol, the text of the CRADA also includes an acknowledgement by BMS that in developing a fair market price for taxol, consideration will be given to the public investment in taxol research and development and the health and safety needs of 
the public. This language is very similar to the fair pricing clause that is included in the model CRADA used by NIH and ADAMHA. A similar clause was present in our license agreement with BMS for the anti-AIDS drug ddI (Videx). In that instance, we believe that the company established a very favorable price for their product, below that of its major competitive product, A2T. Because taxol is not patented, other companies are able to develop this compound for use in treating breast and other types of cancer. Additionally, other companies are developing taxol analogues, some of which conceivably might be more effective or less toxic than taxol itself. It should be recognized that taxol's development will provide a "road map" for the development of taxane and other analogues. We believe that these market forces also will limit the price of taxol.

In order to assist BMS in obtaining Pacific Yew tree bark, NCI has worked with other Federal agencies with jurisdiction over Federal lands that have large concentrations of Pacific Yew trees. Those other agencies, the U.S. Department of Agriculture Forest Service and the Department of the Interior Bureau of Land Management, have entered into a Memorandum of Understanding (MOU) with NCI's parent agency, the Department of Health and Human Services. Under the terms of the MOU, all agencles are cooperating to provide Pacific Yew trees to BMS to meet the urgent requirements of drug supply for current research clinical trials. 
In addition, the Departments of Interior and Agriculture have signed cooperative agreements with BMS to facilitate access to Pacific Yew tree bark from Federal lands. These understandings have been very effective in allowing large-scale collection of yew bark for taxol production over the past year.

Taxol production has increased significantly over the past year due to the excellent cooperation of all parties, and we now have approximately one and a half kilograms per month for clinical trials. This has enabled us to allow NCI Clinical and comprehensive Cancer Centers to provide taxol for certain ovarian cancer patients through an NCI established Treatment Referral Center (TRC). The TRC refers patients who would qualify for this protocol or similar protocols to participating Cancer Centers. over 800 patients have received taxol at these regional cancer centers in the first five months of this program.

The use of yew bark for this purpose has engendered much interest on the part of local businesses and environmentalists who are concerned about the economic and environmental impact of harvesting the Pacific yew. In order to respond to these concerns, agency officials have met with representatives of various groups, both in Washington D.C. and in Portland, oregon and in general have gained their support for the effort to direct all available supplies of Taxus bark to the clinical trials program. I call your attention to the fact that, as part of the 
MOU, BMS has supported a government survey of yew trees on Federal lands, and the USDA has undertaken the establishment of a comprehensive plan for harvesting and protection of the yew.

While for the next one to two years we feel that the harvesting of Taxus bark will be the only effective source for this much needed drug, the long-term solution to the supply problem does not rest with harvesting Pacific Yew trees. The NCI and BMS are working with the biomedical and agricultural research communities to develop alternative methods to produce taxol. These include total synthetic production, partial synthesis, alternative renewable sources, such as needles or twigs, cultivation of faster-growing species, plant tissue culture, hydroponics, etc., all of which would eliminate the need for tree bark.

During the past year, significant progress has been made in these areas. NCI grantees have been able to synthesize the complex taxane ring that lies at the core of the taxol molecule. Other scientists have succeeded in synthesizing the full molevule on an experimental scale, starting with a precursor, Baccatine III, found in needles of the yew and in commercial taxol plants. Renewable sources of taxol have been identifled in commercial nursery plants of the yew family, as well as in the needles of taxus trees in India, Australia and Europe. With NCI and USDA support, a consortium of commercial nurseries, led by the Zelenka Nursery of Michigan and the University of Mississippi, has 
collected large amounts of yew needles from cultivated stock, and has found that this biomass contains substantial amounts of taxol. Because these cuttings are readily available, they constitute a potentially promising source of drug. I am confident that within two to three years we will no longer be dependent on the Pacific Yew as the sole source of this drug.

The NCI has also taken steps to encourage the rapid development and evaluation of new approaches to production of taxol and analogues to taxol. On an emergency basis, NCI provided supplemental funds to grantees conducting research in this area throughout the country to speed up this process.

In addition, on July 27, 1990, NCI issued a Request for Applications (RFA) asking that investigators in the biomedical research community submit new grant applications for Biological and Chemical studies of Taxol. In response to the RFA, 61 proposals were recelved and 16 grants totaling $\$ 2.3$ million were awarded last year. The NCI is also encouraging other private pharmaceutical companies to enter the search for active taxollike compounds that do not require extraction from tree bark.

We have recently signed an agreement to aid in the testing of a taxol analogue, taxotere, under the sponsorship of a BMS competitor, Rhone-Poulanc, a French pharmaceutical company with subsidiaries in the United States. Taxotere appears to have 
promising chemical activity in ovarian cancer, and the company holds several patents on this compound. We will join the company in testing taxotere as a single agent and in combination against ovarian cancer, lung cancer, and other common solid tumors. As this drug is manufactured from precursors found in yew needles, the company will not need to depend on the harvest of trees for its production.

We know that there is great commercial interest in taxol-related compounds and have encouraged this work with grant support, conferences, and staff contacts. We plan to hold an international conference on taxol and related compounds in the fall of 1992.

Perhaps a few words indicating the current limitations of taxol are in order. First, while taxol is an important new experimental drug, it is not a cure for cancer. This drug has certain side-effects that may make its use medically inappropriate in certain cases. Therefore, any decision about the use of this drug must be undertaken by highly qualified medical staff familiar with the side-effects and activity of the agent.

Second, taxol is st1ll an experimental agent. It is not for sale. Its use is carefully regulated by the FDA and other applicable government agencles. Any use of the drug would need to conform to the applicable standards for experimental agents regulated by the FDA. Such use would require adherence to 
principles of informed consent, suitability to enter a research protocol, etc. Not every patient is suitable to enter a taxol research protocol. The physicians at NCI are available to assist primary care physicians to determine the medical eligibility of patients for clinical trials using taxol as well as identifying other treatment options that may be more suitable, when taxol is not available or medically appropriate. our treatment referral center advises physicians regarding appropriate alternatives for patients with ovarian cancer or breast cancer who have failed primary treatment.

In conclusion, I would like to emphasize that NCI recognizes the serious environmental and economic issues surrounding the development of taxol. We have worked carefully with other Federal agencies, the research community, and the private sector to formulate a responsible and environmentally sound policy to meet this public health need. Our first priority has been to ensure the most rapid testing and broadest availability of this agent, an effort that requires the cooperation of government, the public, and a commercial partner. As public officials, we recognize our responsibilities to the American people and to the Congress to ensure that our actions are in the best interest of the public health, but appropriately balanced with other priorities, such as protecting the environment. 
We welcome the opportunity to appear before you today to address your concerns. I would be happy to answer any questions you may have. 



\section{Appendix F}

Pacific Yew Inventories 


\section{Changes Made Since the Draff EIS Appendix F}

Changed inventory figures per latest information from the Forest Service Northern Region.

Removed the discussion on "Sustainability" (see this section in Chapters III \& IV). 


\section{Appendix $\mathrm{F}$}

Inventory

\section{Table of Contents}

Introduction

Forest Service, Pacific Northwest Region

1

Forest Service, Northern Region

2

Bureau of Land Management

State and Private Lands 

Prior to 1991, the Forest Service had no inventory method specifically designed to measure the number of Pacific yew. Any available information was usually obtained as part of inventories designed to measure commercial timber values and volumes. Because Pacific yew is distributed in the forest differently from most commercial species (lower density and clumpy), an inventory design for yew must differ from one that measures relatively homogeneous species, such as Douglas-fir. The inventory providing the best available information of yew stocking (before 1991) was that performed by the Forest Inventory and Analysis Group (FIA) of the Pacific Northwest Research Station (PNW). FIA inventories are ongoing low-intensity, multi-species samples that include Pacific yew. However, the FIA inventories only sampled state and private lands and thus did not supply the kind of information needed for an environmental impact statement for federal lands. Most early estimations of the existing yew populations were developed from this FIA data.

In early 1991, when it became clear that better population information was needed, the Forest Service began developing inventory procedures for Oregon and Washington. This inventory was fieldtested in the summer of 1991, with the inventory completed in 1992. Concurrently, the Forest Service in Idaho and the Bureau of Land Management in Oregon developed similar but unique inventory procedures that were used during the 1992 field season. It is these three inventories that are used in this document to estimate outputs from the alternatives.

In addition to the large-scale inventories that have been taken, site-specific surveys have been carried out by both agencies. These were used to determine where bark harvest could be implemented for the 1991 and 1992 harvest programs. These surveys concentrated on recently harvested timber sales and areas with approved environmental assessments. As more site-specific planning continues, more surveys will be needed to determine the exact locations of Pacific yew stands.

The following sections will describe the inventory and modeling procedures used by the Forest Service Pacific Northwest Region (Region Six), Forest Service Northern Region (Region One), and 
the BLM. Tables showing the results from the modeling include a combined table for each inventory (Region Six, Region One, and BLM), and a series of tables that separate the inventory by forest and BLM district. All three inventories have been combined into one series of tables and can be found in the Pacific yew population and inventory section of Chapter IV.

\section{Forest Service, Pacific Northwest Region}

The Pacific Northwest Region inventory provides information on the characteristics of the vegetation where yew is found. Such characteristics include overstory and understory tree species composition and size distribution; amount and type of existing regeneration; plant association; and distribution of standing dead trees. The implementation of this inventory began during the summer and fall of 1991. Plots measured during 1991 were used in a preliminary analysis to determine if additional sampling was needed. It was determined that more samples were indeed needed, and the inventory was completed during the 1992 field season. The following sections describe the development and methodology of this inventory and report the results.

Inventory Design

Due to the importance of developing quality inventory estimates as soon as possible at a reasonable cost, an inventory design that would minimize the number of field plots to be sampled was chosen. To accomplish this, either a prediction would need to be made as to where Pacific yew would occur and those acres more intensely inventoried, or the acres with a low probability of having yew would need to be eliminated from the inventory.

Two Forest Service ecologists, Miles Hemstrom and Tom Spies, were initially engaged to develop a computer model that would predict the abundance and probability of occurrence of Pacific yew in an area. Such a model would use regression equations derived from previously measured plot data to make predictions about the location of yew habitat. Hemstrom evaluated all westside ecology data that had been collected on the six national forests, while Spies evaluated research data that had been collected by the Pacific Northwest Research Station. Both efforts concluded that 
there is a slight correlation with some variables (aspect, elevation, plant association, etc.), but that none of the correlations were strong enough to develop a regression model for the prediction of Pacific yew locations.

Because a predictive model could not be developed, Hemstrom and Spies then used their experience to instead develop some simple criteria that could be used to reduce the number of acres that would need to be inventoried. The criteria consist of elevation zones and stand conditions where yew would most likely occur. The elevation zones used are: Gifford Pinchot 1500-3500 ft. ; Mt. Hood 2000-3500 ft.; Mt. Baker/Snoqualmie (south half) 1500-4000 ft. ; Rogue River 3000-5000 ft.; Siskiyou 3000-5000 ft.; Umpqua 2000-4500 ft.; and Willamette 1500-4000 ft. Stand conditions are as follows: Optimum Habitat is defined to have 70 percent or more crown closure with a 10 percent or more crown closure in trees 21 inches or larger. Stands that do not meet these criteria are classified as "Other Lands." These criteria were modified for the Siskiyou, Umpqua, and Rogue River National Forests, since they are in more of a mediterranean climate and not a maritime climate as the other forests are. The modifications include dropping the requirement that hemlock be present and inclusion of a requirement that the stands occur on slopes of 0-30 percent. (See Figure 1).

Mapping of the three habitat types was done using data from a computerized satellite land information system (Landsat) in conjunction with a geographical information system (GIS). Resolution for the Landsat data was based on 25 X 25 meter pixels. In other words, each $25 \times 25$ square meter of the national forest was classified as either Optimum, Potential, or Other, based on the above criteria. A contractor (Pacific Meridian) was employed to produce this pixelized map of the forests which resided as a layer of data in the GIS computer. The contractor then divided the forests into five-acre cells each composed of approximately 32 pixels. The computer then tallied the number of pixels in each of the three habitat types within each of the five-acre cells. Each cell was then classified into one of 13 strata based on the mix of Potential, Optimum, and Other acres. (See Table F-1.) 


\section{Criteria Used to Identify Potential Pacific Yew Habitat}

National Forests Inventoried

Gifford Pinchot

Mt. Hood

Mt. Baker/Snoqualmie (south half)

Rogue River

Siskiyou

Umpqua

Willamette

\section{Proper Elevation Zone?}

Gifford Pinchot 1,500-3,500 feet

Mt. Hood 2,000-3,500 feet

Mt.Baker/Snoqualmie(south 1/2) 1,500-4,000 feet

Rogue River 3,000-5,000 feet

Siskiyou 3,000-5,000

Umpqua 2,000-4,500 feet

Willamette $1,500-4,000$ feet

\section{YES}

$70 \%+$ crown closure; $10 \%+$ crown closure in trees with diameters $32 "+$; first, second or predominant species is western hemlock (except Rogue River, Siskiyou and Umpqua NF's); two or more canopy layers; stands on slopes 0-30\% (Rogue River and Umpqua NF's only)

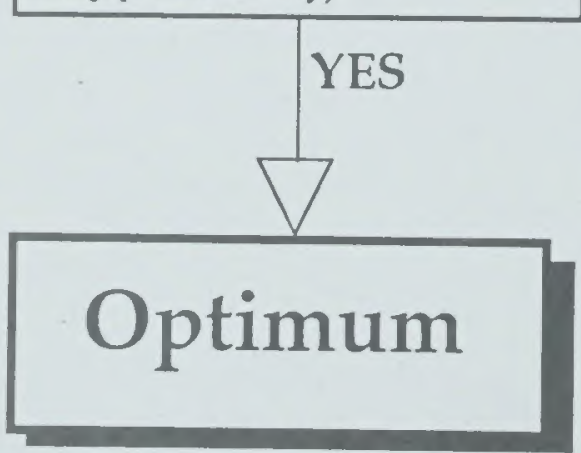

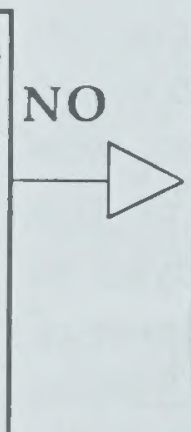

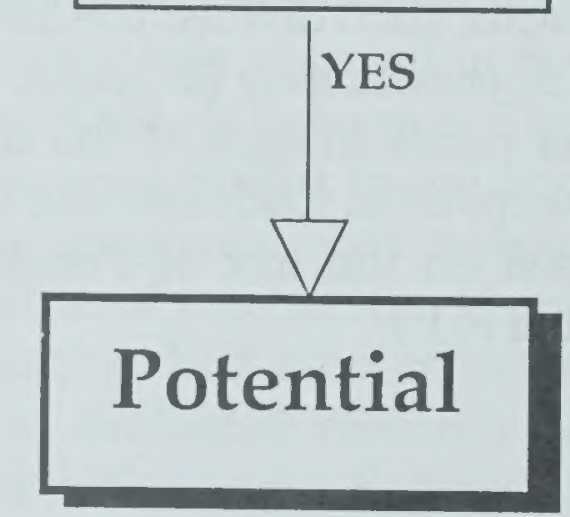

$70 \%+$ crown closure; $10 \%$ crown closure in trees with diameters 21" + ; two or more canopy layers; stands on slopes $0-30 \%$ (Rogue River, Siskiyou and Umpqua NF's only)
(Does not meet elevation criteria)

\section{NO}

(Does not meet crown closure, species, slope, or canopy layer criteria)

\section{Other Lands}


This type of methodology has not previously been used by the Forest Service for forest inventory purposes. However, Landsat data recently gathered for information on old growth forests had the same characteristics needed for yew inventories.

Stratum

Pacific Yew Inventory Strata

Number

Description of Strata
01
4 or more acres are potential; remaining acres can be optimum or other
024 or more acres are optimum; remaining acres can be potential or other
034 or more acres are other; remaining acres can be potential or optimum
043 to 3.9 acres are potential; remaining acres can be optimum or other
053 to 3.9 acres are optimum; remaining acres can be potential or other
063 to 3.9 acres are other; remaining acres can be potential or optimum
072 to 2.9 acres are potential; one or less acre is other; remaining acreage is optimum
082 to 2.9 acres are optimum; one or less acre is other; remaining acreage is potential
092 to 2.9 acres are potential; one or less acre is optimum; remaining acreage is other
102 to 2.9 acres are optimum; one or less acre is potential; remaining acreage is other
112 to 2.9 acres are other; one or less acre is potential; remaining acreage is optimum
122 to 2.9 acres are other; one or less acre is optimum; remaining acreage is potential
13 All other combinations

\section{Table F-1}

On each forest, 100 cells per stratum were randomly selected by computer to serve as a possible sampling population. The selected grid cells were printed on a mylar overlay of the forest's ortho quad map. The forest inventory coordinator eliminated cells that were not totally composed of lands managed by that particular forest. Thirty cells were then selected from those that remained and represented the maximum across all districts on the forest. Each grid cell was transferred from the forest's overlay map to $1: 12,000$ scale aerial photographs and then located in the field. At the end of the 1992 field season, 1875 plots had been sampled in the region. 
During field implementation of the program, crews were sent out to the five-acre grid cells to record occurrences of the following:

Number of Pacific yew trees

All live trees meeting designated specifications (all species)

Canopy layers

Crown closure

Vegetative indicator species

Live yew regeneration

Dead trees

Down woody material

Dead yew trees with symptoms of Phytophthora lateralis infection

Within each square five-acre grid cell, the crews systematically apportioned several areas for the various types of measurements required. First, three belt-transects one chain wide (66 feet) were installed to solely record the occurrence of Pacific yew. Second, four circular plots were installed. Each of these four plots consisted of three concentric plots: a variable radius plot, a 1/20 acre fixed radius plot, and a $1 / 100$ acre fixed radius plot. Within the variable radius plot, all live trees with a 19" Diameter at Breast Height (DBH, 4.5 feet high) and greater were recorded using a 40 Basal Area Factor prism (a measuring device used to determine which trees would be sampled). Within the $1 / 20$ acre fixed radius plot, live trees 5"-18.9" DBH, cover canopy layers, crown closure, forest vegetative indicator species, and groupings of hardwood trees were recorded. Within the 1/100 acre fixed radius plot, live regeneration from 6" tall to 4.9" $\mathrm{DBH}$ was recorded.

In addition, two belt-transects, one chain wide, were installed to record dead trees; and line transects were installed to record down woody material.

Lastly, dead Pacific yew 3" DBH or greater were recorded and examined to determine the presence of Phytophthora lateralis, a root disease associated with Port-Orford-cedar. Information on the presence and severity of root disease pockets within the cell were also recorded. 
Inventory Results

The following table displays the results of the inventory for Forest

Service lands in Oregon and Washington.

\begin{tabular}{|c|c|c|c|c|c|c|c|c|c|}
\hline \multicolumn{10}{|c|}{$\begin{array}{c}\text { Inventory and Diameter Distribution for } \\
\text { Forest Service Pacific Northwest Region (Oregon and }\end{array}$} \\
\hline & $\begin{array}{l}\text { Gifford } \\
\text { Pinchot }\end{array}$ & $\begin{array}{c}\text { Mt Baker } \\
\text { Snoqualmie }\end{array}$ & Mt. Hood & $\begin{array}{l}\text { Rogue } \\
\text { River }\end{array}$ & Siskiyou & Umpqua & Willamette & $\begin{array}{l}\text { Oregon } \\
\text { Forests }\end{array}$ & $\begin{array}{l}\text { Washington } \\
\text { Forests }\end{array}$ \\
\hline $\begin{array}{c}\text { Acres with } \\
\text { Yew }\end{array}$ & 183,635 & 236,543 & 107,556 & 206,145 & 71,169 & 404,592 & 490,484 & $1,279,946$ & 420,178 \\
\hline $\begin{array}{c}\text { Inventoried } \\
\text { Acres }\end{array}$ & 985,560 & 533,710 & 609,560 & 543,770 & 477,540 & 916,810 & $1,362,560$ & $3,910,240$ & $1,519,270$ \\
\hline Total Trees & $8,955,300$ & $6,797,400$ & $1,961,300$ & $8,732,600$ & 352,800 & $6,083,200$ & $8,513,400$ & $25,643,300$ & $15,752,700$ \\
\hline $\begin{array}{l}\text { Diameter } \\
\text { Class }\end{array}$ & $\begin{array}{l}\text { Trees/ } \\
\text { Acre }\end{array}$ & $\begin{array}{l}\text { Trees/ } \\
\text { Acre }\end{array}$ & $\begin{array}{l}\text { Trees/ } \\
\text { Acre }\end{array}$ & $\begin{array}{l}\text { Trees/ } \\
\text { Acre }\end{array}$ & $\begin{array}{l}\text { Trees/ } \\
\text { Acre }\end{array}$ & $\begin{array}{l}\text { Trees/ } \\
\text { Acre }\end{array}$ & $\begin{array}{c}\text { Trees/ } \\
\text { Acre }\end{array}$ & $\begin{array}{c}\text { Trees/ } \\
\text { Acre }\end{array}$ & $\begin{array}{c}\text { Trees/ } \\
\text { Acre }\end{array}$ \\
\hline $1-2.9^{\prime \prime}$ & 40.86 & 17.232 & 11.814 & 20.771 & 1.428 & 8.616 & 11.636 & 12.602 & 32.558 \\
\hline $3-4.9^{\prime \prime}$ & 5.161 & 7.225 & 3.42 & 9.436 & 0.366 & 2.691 & 2.551 & 3.833 & 5.885 \\
\hline $5 \cdot 6.9^{\prime \prime}$ & 1.932 & 2.859 & 1.762 & 5.702 & 1.643 & 1.601 & 1.128 & 2.091 & 2.258 \\
\hline $7 \cdot 8.9^{\prime \prime}$ & 0.64 & 1.082 & 0.722 & 2.772 & 0.25 & 0.795 & 1.021 & 1.185 & 0.795 \\
\hline $9 \cdot 10.9^{\prime \prime}$ & 0.109 & 0.163 & 0.302 & 1.842 & 0.387 & 0.518 & 0.466 & 0.669 & 0.128 \\
\hline $11 \cdot 12.9^{\prime \prime}$ & 0.025 & 0.099 & 0.099 & 0.901 & 0.418 & 0.249 & .252 & 0.327 & 0.051 \\
\hline $13 \cdot 14.9 "$ & 0.031 & 0.002 & 0.078 & 0.335 & 0.026 & 0.337 & 0.165 & 0.222 & 0.021 \\
\hline $15-16.9^{\prime \prime}$ & 0.004 & 0.004 & 0.028 & 0.337 & 0.017 & 0.149 & 0.085 & 0.132 & 0.004 \\
\hline $17-18.9^{\prime \prime}$ & 0.004 & 0.068 & 0.002 & 0.105 & 0.013 & 0.026 & 0.033 & 0.037 & 0.027 \\
\hline $19-20.9^{\prime \prime}$ & 0.001 & 0 & 0 & 0.099 & 0.375 & 0.011 & 0.018 & 0.026 & 0.001 \\
\hline $21+"$ & 0.002 & 0.003 & 0.008 & 0.063 & 0.034 & 0.042 & 0.007 & 0.025 & 0.002 \\
\hline $\begin{array}{l}\text { Total } \\
\text { TPA }\end{array}$ & 48.769 & 28.737 & 18.235 & 42.363 & 4.957 & 15.035 & 17.362 & 21.149 & 41.730 \\
\hline
\end{tabular}

\section{Modeling Process}

The computer modeling of the Pacific Northwest Region data was done by a contractor-Mason, Bruce and Girard, Inc., (MB\&G). The Forest Service supplied yew inventory data, summarized into stand tables by DBH, for each of the 13 strata in its yew inventory. These data came from field inventories the Forest Service conducted in 1991 and 1992. These stand tables were obtained by summarizing only the plots on which Pacific yew was found. The Forest Service also supplied, by stratum, the total number of plots 
and the number of plots on which yew occurred so that the amount of yew available could be proportionally reduced.

The Forest Service also supplied the acres in each inventory strata and classified how those acres would be treated in the alternatives. The different classes reflected whether yew harvesting was allowed by the forest plan. Provisions were also made to exclude yew harvest in riparian zones in harvested areas.

The Forest Service data was supplied in spreadsheets. MB\&G's first step was to convert the basic stand tables and tables of acres into a relational database (Microrim's R:Base). Data was then checked to ensure that all data supplied by the Forest Service was properly converted.

Bark weight calculations for each diameter class in the Forest Service stand tables were made using the Bureau of Land Management's relationships of stump diameter and height to pounds of bark. These calculations made the conservative assumption that stump diameter and DBH are the same. Trees between two and three inches in diameter were assumed to have two pounds of bark.

The alternatives designate levels of harvest in terms of the maximum percent of trees harvested and the minimum number of trees (for three diameter classes) left (see Chapter II). Quite simply, yew harvest can remove up to the maximum percent allowed (under the alternatives) so long as the required minimum number of trees are left.

The harvesting parameters set forth in the Description of Alternatives were fed into a program which produced a summary of harvestable yew trees and weight for each land class in each stratum and alternative.

\section{Modeling Results}

The following tables display the results of modeling the alternative using the inventory data from the Pacific Northwest Region. 
All National Forests - Pacific Northwest Region (Oregon and Washington)

\begin{tabular}{|c|c|c|c|c|c|c|c|}
\hline Alternatives & $\begin{array}{c}\text { Total Acres } \\
\text { Inventoried }\end{array}$ & $\begin{array}{c}\text { Total Number } \\
\text { of Trees on } \\
\text { Inventoried } \\
\text { Acres* }\end{array}$ & $\begin{array}{c}\text { Acres Entered } \\
\text { by this } \\
\text { Alternative } \\
\text { (next 5 yrs) }\end{array}$ & $\begin{array}{c}\text { Trees } \\
\text { Harvested by } \\
\text { this } \\
\text { Alternative } \\
\text { (next 5 yrs) }\end{array}$ & $\begin{array}{c}\text { Trees } \\
\text { Harvested by } \\
\text { this Alternative } \\
\text { (next 5 yrs) } \\
50 \%-25 \% \\
\text { reduction (M) }\end{array}$ & $\begin{array}{c}\text { Pounds of } \\
\text { Dry Bark } \\
\text { (next 5 yrs) }\end{array}$ & $\begin{array}{c}\text { Pounds of Dry } \\
\text { Bark } \\
\text { (next 5 yrs) } \\
50 \%-25 \% \\
\text { reduction (M) }\end{array}$ \\
\hline A & $5,426,510$ & $41,396,000$ & 0 & 0 & 0 & 0 & 0 \\
\hline B & $5,426,510$ & $41,396,000$ & 91,650 & 389,000 & $200-290$ & $1,897,000$ & $950-1,430$ \\
\hline C & $5,426,510$ & $41,396,000$ & $2,184,100$ & $2,319,600$ & $1,160-1,740$ & $7,493,960$ & $3,750-5,620$ \\
\hline D & $5,426,510$ & $41,396,000$ & $2,184,100$ & $3,976,900$ & $1,990-2,990$ & $12,433,160$ & $6,220-9,320$ \\
\hline F & $5,426,510$ & $41,396,000$ & $2,184,100$ & $6,586,300$ & $3,300-4,940$ & $22,375,280$ & $11,190-16,790$ \\
\hline G1 & $5,426,510$ & $41,396,000$ & $2,184,100$ & $4,953,300$ & $2,480-3,710$ & $23,716,840$ & $11,860-17,790$ \\
\hline G2 & $5,426,510$ & $41,396,000$ & $3,143,330$ & $6,881,200$ & $3,440-5,160$ & $29,061,720$ & $14,530-21,800$ \\
\hline${ }^{*}$ Trees $>1{ }^{\prime \prime}$ DBH & & & & & & \\
\hline
\end{tabular}

\begin{tabular}{|c|c|c|c|c|c|c|c|}
\hline \multicolumn{8}{|c|}{ Gifford Pinchot National Forest } \\
\hline Alternatives & $\begin{array}{l}\text { Total Acres } \\
\text { Inventoried }\end{array}$ & $\begin{array}{c}\text { Total Number } \\
\text { of Trees on } \\
\text { Inventoried } \\
\text { Acres* }\end{array}$ & $\begin{array}{c}\text { Acres Entered } \\
\text { by this } \\
\text { Alternative } \\
\text { (next } 5 \text { yrs) }\end{array}$ & $\begin{array}{c}\text { Trees } \\
\text { Harvested by } \\
\text { this } \\
\text { Alternative } \\
\text { (next } 5 \text { yrs) }\end{array}$ & $\begin{array}{c}\text { Trees } \\
\text { Harvested by } \\
\text { this Alternative } \\
\text { (next } 5 \text { yrs) } \\
50 \%-25 \% \\
\text { reduction (M) }\end{array}$ & $\begin{array}{l}\text { Pounds of } \\
\text { Dry Bark } \\
\text { (next } 5 \text { yrs) }\end{array}$ & $\begin{array}{c}\text { Pounds of } \\
\text { Dry Bark } \\
\text { (next } 5 \mathrm{yrs} \text { ) } \\
50 \%-25 \% \\
\text { reduction (M) }\end{array}$ \\
\hline A & 982,560 & $8,955,300$ & 0 & 0 & 0 & 0 & 0 \\
\hline B & 982,560 & $8,955,300$ & 14,840 & 60,200 & $30-45$ & 122,360 & $61-92$ \\
\hline $\mathrm{C}$ & 982,560 & $8,955,300$ & 324,880 & 371,800 & 186,279 & 710,400 & $355-533$ \\
\hline D & 982,560 & $8,955,300$ & 324,880 & 679,400 & $190-285$ & $1,288,240$ & $644-966$ \\
\hline F & 982,560 & $8,955,300$ & 324,880 & 995,100 & $498-746$ & $1,886,440$ & $943-1,415$ \\
\hline G1 & 982,560 & $8,955,300$ & 324,880 & 688,600 & $344-516$ & $1,400,640$ & $700-1,050$ \\
\hline $\mathrm{G} 2$ & 982,560 & $8,955,300$ & 560,210 & $1,153,200$ & $577-865$ & $2,276,720$ & $1,138-1,708$ \\
\hline
\end{tabular}




\begin{tabular}{|c|c|c|c|c|c|c|c|}
\hline \multicolumn{2}{|c|}{ Mt. Baker-Snoqualmie National Forest } \\
\hline Alternatives & $\begin{array}{c}\text { Total Acres } \\
\text { Inventoried }\end{array}$ & $\begin{array}{c}\text { Total Number } \\
\text { of Trees on } \\
\text { Inventoried } \\
\text { Acres* }\end{array}$ & $\begin{array}{c}\text { Acres Entered } \\
\text { by this } \\
\text { Alternative } \\
\text { (next 5 yrs) }\end{array}$ & $\begin{array}{c}\text { Trees } \\
\text { Harvested by } \\
\text { this } \\
\text { Alternative } \\
\text { (next 5 yrs) }\end{array}$ & $\begin{array}{c}\text { Trees } \\
\text { Harvested by } \\
\text { this Alternative } \\
\text { (next 5 yrs) } \\
50 \%-25 \% \\
\text { reduction (M) }\end{array}$ & $\begin{array}{c}\text { Pounds of } \\
\text { Dry Bark } \\
\text { (next 5 yrs) }\end{array}$ & $\begin{array}{c}\text { Pounds of } \\
\text { Dry Bark } \\
\text { (next 5 yrs) } \\
50 \%-25 \% \\
\text { reduction (M) }\end{array}$ \\
\hline A & 533,710 & $6,797,400$ & 0 & 0 & 0 & 0 & 0 \\
\hline B & 533,710 & $6,797,400$ & 1,510 & 11,300 & $6-8$ & 34,960 & $17-26$ \\
\hline C & 533,710 & $6,797,400$ & 90,580 & 174,100 & $87-131$ & 485,120 & $243-364$ \\
\hline D & 533,710 & $6,797,400$ & 90,580 & 336,800 & $168-253$ & 935,040 & $468-701$ \\
\hline F & 533,710 & $6,797,400$ & 90,580 & 499,700 & $250-375$ & $1,385,440$ & $693-1,039$ \\
\hline G1 & 533,710 & $6,797,400$ & 90,580 & 343,500 & $172-258$ & $1,066,200$ & $533-800$ \\
\hline G2 & 533,710 & $6,797,400$ & 163,260 & 616,700 & $308-463$ & $1,820,280$ & $910-1,365$ \\
\hline *Trees $>1$ " DBH & & & & & & \\
\hline
\end{tabular}

\begin{tabular}{|c|c|c|c|c|c|c|c|}
\hline \multicolumn{8}{|c|}{ Mt. Hood National Forest } \\
\hline Alternatives & $\begin{array}{l}\text { Total Acres } \\
\text { Inventoried }\end{array}$ & $\begin{array}{c}\text { Total Number } \\
\text { of Trees on } \\
\text { Inventoried } \\
\text { Acres* }\end{array}$ & $\begin{array}{c}\text { Acres Entered } \\
\text { by this } \\
\text { Alternative } \\
\text { (next } 5 \text { yrs) }\end{array}$ & $\begin{array}{c}\text { Trees } \\
\text { Harvested by } \\
\text { this } \\
\text { Alternative } \\
\text { (next } 5 \text { yrs) }\end{array}$ & $\begin{array}{c}\text { Trees } \\
\text { Harvested by } \\
\text { this Alternative } \\
\text { (next } 5 \text { yrs) } \\
50 \%-25 \% \\
\text { reduction (M) }\end{array}$ & $\begin{array}{l}\text { Pounds of } \\
\text { Dry Bark } \\
\text { (next } 5 \text { yrs) }\end{array}$ & $\begin{array}{c}\text { Pounds of } \\
\text { Dry Bark } \\
\text { (next } 5 \text { yrs) } \\
50 \%-25 \% \\
\text { reduction (M) }\end{array}$ \\
\hline A & 609,560 & $1,961,300$ & 0 & 0 & 0 & 0 & 0 \\
\hline $\mathrm{B}$ & 609,560 & $1,961,300$ & 7,750 & 12,700 & $6-10$ & 47,160 & $24-35$ \\
\hline $\mathrm{C}$ & 609,560 & $1,961,300$ & 293,740 & 115,800 & $58-87$ & 354,080 & $177-266$ \\
\hline $\mathrm{D}$ & 609,560 & $1,961,300$ & 293,740 & 203,500 & $102-153$ & 614,280 & $307-461$ \\
\hline $\mathrm{F}$ & 609,560 & $1,961,300$ & 293,740 & 335,000 & $168-251$ & 986,600 & $493-740$ \\
\hline G1 & 609,560 & $1,961,300$ & 293,740 & 247,800 & $124-186$ & 917,800 & $459-688$ \\
\hline $\mathrm{G} 2$ & 609,560 & $1,961,300$ & 364,550 & 317,100 & 159,238 & $1,241,160$ & $621-931$ \\
\hline
\end{tabular}




\begin{tabular}{|c|c|c|c|c|c|c|c|}
\hline \multicolumn{8}{|c|}{ Rogue River National Forest } \\
\hline Alternatives & $\begin{array}{l}\text { Total Acres } \\
\text { Inventoried }\end{array}$ & $\begin{array}{l}\text { Total Number } \\
\text { of Trees on } \\
\text { Inventoried } \\
\text { Acres* }\end{array}$ & $\begin{array}{c}\text { Acres Entered } \\
\text { by this } \\
\text { Alternative } \\
\text { (next } 5 \text { yrs) }\end{array}$ & $\begin{array}{c}\text { Trees } \\
\text { Harvested by } \\
\text { this } \\
\text { Alternative } \\
\text { (next } 5 \text { yrs) }\end{array}$ & $\begin{array}{c}\text { Trees } \\
\text { Harvested by } \\
\text { this Alternative } \\
\text { (next } 5 \mathrm{yrs} \text { ) } \\
50 \%-25 \% \\
\text { reduction (M) }\end{array}$ & $\begin{array}{l}\text { Pounds of } \\
\text { Dry Bark } \\
\text { (next } 5 \text { yrs) }\end{array}$ & $\begin{array}{l}\text { Pounds of } \\
\text { Dry Bark } \\
\text { (next } 5 \text { yrs) } \\
50 \%-25 \% \\
\text { reduction (M) }\end{array}$ \\
\hline A & 543,770 & $8,732,600$ & 0 & 0 & 0 & 0 & 0 \\
\hline $\mathrm{B}$ & 543,770 & $8,732,600$ & 9,200 & 99,200 & $50-74$ & 582,000 & $291-437$ \\
\hline $\mathrm{C}$ & 543,770 & $8,732,600$ & 252,670 & 670,100 & $335-503$ & $2,555,160$ & $1,278-1,916$ \\
\hline $\mathrm{D}$ & 543,770 & $8,732,600$ & 252,670 & $1,240,100$ & $620-930$ & $4,517,080$ & $2,259-3,388$ \\
\hline $\mathrm{F}$ & 543,770 & $8,732,600$ & 252,670 & $1,944,800$ & $972-1,459$ & $9,350,680$ & $4,675-7,013$ \\
\hline G1 & 543,770 & $8,732,600$ & 252,670 & $1,411,700$ & $706-1,059$ & $8,278,840$ & $4,139-6,209$ \\
\hline G2 & 543,770 & $8,732,600$ & 334,650 & $1,787,800$ & $894-1,341$ & $9,578,880$ & $4,789-7,184$ \\
\hline
\end{tabular}

\begin{tabular}{|c|c|c|c|c|c|c|c|}
\hline \multicolumn{8}{|c|}{ Siskiyou National Forest } \\
\hline Alternatives & $\begin{array}{l}\text { Total Acres } \\
\text { Inventoried }\end{array}$ & $\begin{array}{c}\text { Total Number } \\
\text { of Trees on } \\
\text { Inventoried } \\
\text { Acres* }\end{array}$ & $\begin{array}{c}\text { Acres Entered } \\
\text { by this } \\
\text { Alternative } \\
\text { (next } 5 \text { yrs) }\end{array}$ & $\begin{array}{c}\text { Trees } \\
\text { Harvested by } \\
\text { this } \\
\text { Alternative } \\
\text { (next } 5 \text { yrs) }\end{array}$ & $\begin{array}{c}\text { Trees } \\
\text { Harvested by } \\
\text { this Alternative } \\
\text { (next } 5 \text { yrs) } \\
50 \%-25 \% \\
\text { reduction (M) }\end{array}$ & $\begin{array}{c}\text { Pounds of } \\
\text { Dry Bark } \\
\text { (next } 5 \text { yrs) }\end{array}$ & $\begin{array}{l}\text { Pounds of } \\
\text { Dry Bark } \\
\text { (next } 5 \text { yrs) } \\
50 \%-25 \% \\
\text { reduction (M) }\end{array}$ \\
\hline A & 477,540 & 352,800 & 0 & 0 & 0 & 0 & 0 \\
\hline B & 477,540 & 352,800 & 8,350 & 5,600 & $3-4$ & 51,680 & $26-39$ \\
\hline $\mathrm{C}$ & 477,540 & 352,800 & 128,770 & 10,200 & $5-8$ & 66,240 & $33-50$ \\
\hline $\mathrm{D}$ & 477,540 & 352,800 & 128,770 & 11,100 & $6-8$ & 69,320 & $35-52$ \\
\hline$F$ & 477,540 & 352,800 & 128,770 & 29,400 & $15-22$ & 147,800 & $74-111$ \\
\hline G1 & 477,540 & 352,800 & 128,770 & 46,300 & $23-35$ & 424,160 & $212-318$ \\
\hline $\mathrm{G} 2$ & 477,540 & 352,800 & 128,770 & 46,400 & $23-35$ & 424,360 & $212-318$ \\
\hline
\end{tabular}




\begin{tabular}{|c|c|c|c|c|c|c|c|}
\hline \multicolumn{8}{|c|}{ Umpqua National Forest } \\
\hline Alternatives & $\begin{array}{l}\text { Total Acres } \\
\text { Inventoried }\end{array}$ & $\begin{array}{l}\text { Total Number } \\
\text { of Trees on } \\
\text { Inventoried } \\
\text { Acres* }\end{array}$ & $\begin{array}{c}\text { Acres Entered } \\
\text { by this } \\
\text { Alternative } \\
\text { (next } 5 \text { yrs) }\end{array}$ & $\begin{array}{c}\text { Trees } \\
\text { Harvested by } \\
\text { this } \\
\text { Alternative } \\
\text { (next } 5 \text { yrs) }\end{array}$ & $\begin{array}{l}\text { Trees } \\
\text { Harvested by } \\
\text { this Alternative } \\
\text { (next } 5 \text { yrs) } \\
50 \%-25 \% \\
\text { reduction (M) }\end{array}$ & $\begin{array}{l}\text { Pounds of } \\
\text { Dry Bark } \\
\text { (next } 5 \text { yrs) }\end{array}$ & $\begin{array}{c}\text { Pounds of Dry } \\
\text { Bark } \\
\text { (next } 5 \text { yrs) } \\
50 \%-25 \% \\
\text { reduction (M) }\end{array}$ \\
\hline A & 916,810 & $6,083,200$ & 0 & 0 & 0 & 0 & 0 \\
\hline B & 916,810 & $6,083,200$ & 25,690 & 115,200 & $58-86$ & 633,240 & $317-475$ \\
\hline $\mathrm{C}$ & 916,810 & $6,083,200$ & 449,740 & 478,100 & $239-359$ & $1,662,240$ & $831-1,247$ \\
\hline $\mathrm{D}$ & 916,810 & $6,083,200$ & 449,740 & 783,900 & $392-588$ & $2,503,040$ & $1,252-1877$ \\
\hline $\mathrm{F}$ & 916,810 & $6,083,200$ & 449,740 & $1,328,300$ & $664-996$ & $4,139,880$ & $2,070-3,105$ \\
\hline G1 & 916,810 & $6,083,200$ & 449,740 & $1,065,900$ & $533-799$ & $5,860,040$ & $2,930-4,395$ \\
\hline $\mathrm{G} 2$ & 916,810 & $6,083,200$ & 580,340 & $1,300,200$ & $650-975$ & $6,511,160$ & $3,256-4,883$ \\
\hline
\end{tabular}

\begin{tabular}{|c|c|c|c|c|c|c|c|}
\hline \multicolumn{8}{|c|}{ Willamette National Forest } \\
\hline Alternatives & $\begin{array}{l}\text { Total Acres } \\
\text { Inventoried }\end{array}$ & $\begin{array}{c}\text { Total Number } \\
\text { of Trees on } \\
\text { Inventoried } \\
\text { Acres* }\end{array}$ & $\begin{array}{c}\text { Acres Entered } \\
\text { by this } \\
\text { Alternative } \\
\text { (next } 5 \text { yrs) }\end{array}$ & $\begin{array}{c}\text { Trees } \\
\text { Harvested by } \\
\text { this } \\
\text { Alternative } \\
\text { (next } 5 \text { yrs) }\end{array}$ & $\begin{array}{c}\text { Trees } \\
\text { Harvested by } \\
\text { this Alternative } \\
\text { (next } 5 \text { yrs) } \\
50 \%-25 \% \\
\text { reduction (M) }\end{array}$ & $\begin{array}{c}\text { Pounds of } \\
\text { Dry Bark } \\
\text { (next } 5 \text { yrs) }\end{array}$ & $\begin{array}{l}\text { Pounds of } \\
\text { Dry Bark } \\
\text { (next } 5 \text { yrs) } \\
50 \%-25 \% \\
\text { reduction (M) }\end{array}$ \\
\hline A & $1,362,560$ & $8,513,400$ & 0 & 0 & 0 & 0 & 0 \\
\hline B & $1,362,560$ & $8,513,400$ & 24,310 & 84,800 & $42-64$ & 425,600 & $213-319$ \\
\hline $\mathrm{C}$ & $1,362,560$ & $8,513,400$ & 643,720 & 499,500 & $250-375$ & $1,660,720$ & $830-1,246$ \\
\hline D & $1,362,560$ & $8,513,400$ & 643,720 & 722,100 & $361-542$ & $2,506,160$ & $1,253-1,880$ \\
\hline F & $1,362,560$ & $8,513,400$ & 643,720 & $1,454,000$ & $727-1,091$ & $4,478,440$ & $2,239-3,359$ \\
\hline G1 & $1,362,560$ & $8,513,400$ & 643,720 & $1,149,500$ & $575-862$ & $5,769,160$ & $2,885-4,327$ \\
\hline $\mathrm{G} 2$ & $1,362,560$ & $8,513,400$ & $1,008,850$ & $1,659,800$ & $830-1,245$ & $7,326,160$ & $3,663-5,495$ \\
\hline
\end{tabular}




\section{Forest Service, Northern Region}

Because Region One did not have any existing Landsat data or GIS information, a different inventory design wasutilized. At the time of the Region One inventory, it was felt that the only area where yew was at high enough concentrations to be harvestable was on one portion of the $\mathrm{Nez}$ Perce National Forest. Although Pacific yew does occur in smaller concentrations in other places, it would take take a tremendous effort to sample and it is unlikely that additional areas suitable for harvest would be located. At the time of inventory, shrub-form Pacific yew on the Flathead National Forest was not considered a viable resource and was not included as part of the inventoried area. This is similar to what was done in the Pacific Northwest Region when it was decided to concentrate inventory efforts on westside forests. Both efforts would produce conservative estimates of the total number of trees.

\section{Inventory Design}

An inventory area composed of 134,357acres was located on the $\mathrm{Nez}$ Perce National Forest. The area was divided into a series of polygons using stand atlas and moose winter range maps. Based on expected yew density, moose winter range status, and accessibility, each polygon was classified into three sampling intensities:

None - (No Sample) yew expected infrequently or not at all;

Low - (0.5 Percent Sample) low density patches or scattered yew expected across polygon. (Areas with poor access); and

High - (1 Percent Sample) High density patches or continuous yew expected across polygon.

Crews located and measured 1/20th acre (26.3') fixed plots evenly spaced through the polygon that was sampled. Those polygons which were classified as low potential for having yew had plots spaced on a $10 \mathrm{x} 10$ chain (66-foot) grid. This produced a sampling intensity of .5 percent of the area. Polygons classified as high probability of yew had plots spaced on a $7 \times 7$ chain grid, thus producing a 1.0 percent sampling intensity. At each plot the following attributes were recorded:

--Yew crown closure;

--Crown closure of non-yew species;

--Primary and secondary overstory species;

--Occurrence of past logging;

--Moose use; 
--Slope, aspect, and topography;

--Whether the plot was located in a riparian area;

--Presence or non-presence of certain browse species; and

--General tree information (diameter class, stem count, height).

Inventory Results

The following table shows the results of the inventory of the Nez Perce National Forest

\begin{tabular}{|c|c|c|c|c|c|c|c|c|}
\hline & & & Diameter & Distril & ution & & & \\
\hline & & Forest & Service I & gion 1 & (Nez Perc & & & \\
\hline $\begin{array}{c}\text { Diameter } \\
\text { Class }\end{array}$ & $\begin{array}{c}\text { Shrubs } \\
>3^{\prime \prime}\end{array}$ & $3-5.9^{\prime \prime}$ & $6-7.9^{\prime \prime}$ & $8-9.9^{\prime \prime}$ & 10.15 .9 & $16-19.9$ & $20+$ & Total \\
\hline Total Trees & $1,380,721$ & $3,108,475$ & 888,184 & 480,524 & 424,613 & 50,410 & 21,648 & $6,354,575$ \\
\hline Trees/Acre & 10.28 & 23.14 & 6.61 & 3.58 & 3.16 & 0.38 & 0.16 & 47.3 \\
\hline Trees $>3 "$ DB & & ntoried & res $=13$ & & & & & \\
\hline
\end{tabular}

\section{Modeling Process}

An Oracle database was used to process the plot information and to model the output from the alternatives. The approach was similar to what was done for the Pacific Northwest Region, except this method did not allow for simulation of a minimum number of leave trees. Consequently, the results show little difference between alternatives which include the number of leave trees as a variable. 


\section{Modeling Results}

The following table displays the results of modeling the alternatives using the inventory data from Region One.

\begin{tabular}{|c|c|c|c|c|c|c|c|}
\hline \multicolumn{8}{|c|}{$\begin{array}{l}\text { Nez Perce National Forest } \\
\text { (only Forest in Region 1) }\end{array}$} \\
\hline Alternatives & $\begin{array}{l}\text { Total Acres } \\
\text { Inventoried }\end{array}$ & $\begin{array}{l}\text { Total } \\
\text { Number of } \\
\text { Trees on } \\
\text { Inventoried } \\
\text { Acres* }\end{array}$ & $\begin{array}{c}\text { Acres } \\
\text { Entered by } \\
\text { this } \\
\text { Alternative } \\
\text { (next } 5 \text { yrs) }\end{array}$ & $\begin{array}{c}\text { Trees } \\
\text { Harvested by } \\
\text { this } \\
\text { Alternative } \\
\text { (next } 5 \text { yrs) }\end{array}$ & $\begin{array}{c}\text { Trees } \\
\text { Harvested by } \\
\text { this Alternative } \\
\text { (next } 5 \text { yrs) } \\
50 \%-25 \% \\
\text { reduction (M) }\end{array}$ & $\begin{array}{l}\text { Pounds of } \\
\text { Dry Bark } \\
\text { (next } 5 \text { yrs) }\end{array}$ & $\begin{array}{c}\text { Pounds of } \\
\text { Dry Bark } \\
\text { (next } 5 \text { yrs) } \\
50 \%-25 \% \\
\text { reduction } \\
\text { (M) }\end{array}$ \\
\hline $\mathbf{A}$ & 134,357 & $6,355,000$ & 0 & 0 & 0 & 0 & 0 \\
\hline B & 134,357 & $6,355,000$ & 3,070 & 91,000 & $50-70$ & 427,000 & $210-320$ \\
\hline $\mathrm{C}$ & 134,357 & $6,355,000$ & 67,870 & 600,000 & $300-450$ & $2,950,000$ & $1,480-2,210$ \\
\hline D & 134,357 & $6,355,000$ & 67,870 & $1,114,000$ & $560-840$ & $5,971,000$ & $2,740-4,100$ \\
\hline $\mathbf{F}$ & 134,357 & $6,355,000$ & 67,870 & $1,622,000$ & $810-1,220$ & $7,993,000$ & $4,000-5,980$ \\
\hline G1 & 134,357 & $6,355,000$ & 67,870 & $1,114,000$ & $560-840$ & $5,471,000$ & $2,740-4,100$ \\
\hline G2 & 134,357 & $6,355,000$ & 67,870 & $1,114,000$ & $560-840$ & $5,471,000$ & $2,740-4,100$ \\
\hline
\end{tabular}

\section{Bureau of Land Management}

After reviewing the results from the Pacific Northwest Region, 1991 Pacific yew inventory, the BLM developed similar procedures for collecting information. Because the BLM did not have any existing Landsat data and only partial GIS stand coverage, the agency utilized more local knowledge in determining where to concentrate their inventories.

\section{Inventory Design}

All BLM forested areas, constituting slightly more than two million acres on six districts in western Oregon, were inventoried for Pacific yew. Each of the six districts were stratified into two-to-six strata based on the district's determination as to the probability of finding yew. The southern districts, where yew was known to occur in large quantities, were stratified to a greater extent than on northern districts, where yew was less likely to occur. 
Strictly speaking, the inventory design consisted of two stages with stratification. Stands were chosen with probability proportional to size in the first stage, and one plot selected with equal probability per selected stand in the second stage. Due to the selfweighing features of the design, the data was analyzed as a stratified simple random inventory because every sampling unit in the stratum had an equal chance of being selected.

Two plot designs were utilized: one for the riparian stratum identified in the Roseburg and Medford Districts, and one for all other strata. The most commonly used design consisted of a twoacre area where all yew trees with a diameter greater than oneinch at breast height were recorded and several additional plots of different sizes were co-located within the two-acre area. There were four 1/10-acre plots for all live and dead trees greater than five inches, four $1 / 100$-acre plots for all trees less than five inches, and a line transect for down logs within the two-acre plot. The riparian plot consisted of a half-acre where all yew one inch at breast height were recorded, and two 1/100-acre and a down-log transect with the same information recorded as for the larger plot.

Live yew one inch in diameter and larger was the basis for the yew analysis. Yew bark yields per tree were supplied by Hauser Northwest based on a single measurement at stump height. Diameters were recorded at DBH (diameter at breast height) for single stem trees. Diameters for multi-stem trees were recorded at $\mathrm{DBH}$ if the tree forked below $\mathrm{DBH}$ and above the fork for forks that occurred below the live crown. Forks that occurred within the crown were treated as a single-stem tree. Bark yields were based on the largest diameter and the tallest stem for multi-stem trees.

Trees were sorted by diameter within each of the three diameter classes. Leave trees within each class were the smallest trees and progressed towards the larger diameters until either the criterion for that class was met or all of the trees were left, whichever was reached first. One-inch trees qualified as leave trees, even though they were classified as sub-merchantable. 


\section{Inventory Results}

The following table displays the results of the inventory of Bureau of Land Management lands in Oregon.

\begin{tabular}{|c|c|c|c|c|c|c|c|}
\hline \multicolumn{8}{|c|}{$\begin{array}{l}\text { Inventory and Diameter Distribution } \\
\text { Bureau of Land Management in Oregon }\end{array}$} \\
\hline & Salem & Eugene & Roseburg & Coos Bay & Medford & Lakeview & $\begin{array}{c}\text { All } \\
\text { Districts }\end{array}$ \\
\hline \begin{tabular}{|c|}
$\begin{array}{c}\text { Inventoried } \\
\text { Acres }\end{array}$ \\
\end{tabular} & 369,912 & 302,293 & 390,967 & 309,018 & 612,424 & 48,064 & $2,032,679$ \\
\hline Total Trees & 340,763 & 105,744 & 846,647 & 41,630 & 743,319 & 6,525 & $2,084,628$ \\
\hline $\begin{array}{l}\text { Diameter } \\
\text { Class }\end{array}$ & $\begin{array}{l}\text { Trees/ } \\
\text { Acre }\end{array}$ & $\begin{array}{l}\text { Trees/ } \\
\text { Acre }\end{array}$ & $\begin{array}{l}\text { Trees/ } \\
\text { Acre }\end{array}$ & $\begin{array}{l}\text { Trees/ } \\
\text { Acre }\end{array}$ & $\begin{array}{l}\text { Trees/ } \\
\text { Acre }\end{array}$ & $\begin{array}{l}\text { Trees/ } \\
\text { Acre }\end{array}$ & $\begin{array}{l}\text { Trees/ } \\
\text { Acre }\end{array}$ \\
\hline $0-0.9^{\prime \prime}$ & 5.16 & 1.76 & 4.99 & 0.7 & 6.21 & 1.9 & 4.18 \\
\hline $1-1.9^{\prime \prime}$ & 0.22 & 0.03 & 0.33 & 0.01 & 0.18 & 0.02 & 0.16 \\
\hline $2-2.9^{\prime \prime}$ & 0.25 & 0.02 & 0.38 & 0.03 & 0.22 & 0.04 & 0.19 \\
\hline 3-3.9" & 0.11 & 0.04 & 0.4 & 0.02 & 0.22 & 0.04 & 0.18 \\
\hline $4-4.9^{\prime \prime}$ & 0.09 & 0.05 & 0.27 & 0.02 & 0.15 & 0.03 & 0.12 \\
\hline $5-6.9^{\prime \prime}$ & 0.15 & 0.02 & 0.35 & 0.2 & 0.17 & 0.01 & 0.15 \\
\hline 7-8.9" & 0.07 & 0.03 & 0.18 & 0.01 & 0.11 & 0.01 & 0.09 \\
\hline 9-10.9" & 0.01 & 0 & 0.15 & 0 & 0.07 & 0 & 0.05 \\
\hline $11-12.9^{\prime \prime}$ & 0.02 & 0.08 & 0.04 & 0.01 & 0.04 & 0 & 0.03 \\
\hline $13-14.9^{\prime \prime}$ & 0.01 & 0.04 & 0.03 & 0 & 0.03 & 0 & 0.02 \\
\hline 15-16.9" & 0 & 0.01 & 0.02 & 0.01 & 0.01 & 0 & 0.01 \\
\hline 17-18.9" & 0 & 0.01 & 0.01 & 0 & 0.01 & 0 & 0.01 \\
\hline $19-20.9^{\prime \prime}$ & 0 & 0.01 & 0 & 0 & 0 & 0 & 0 \\
\hline $21+"$ & 0 & 0.01 & 0 & 0 & 0 & 0 & 0 \\
\hline $\begin{array}{c}\text { Total } \\
\text { TPA } \\
0-21+"\end{array}$ & 6.09 & 2.11 & 7.15 & 1.01 & 7.42 & 2.05 & 5.19 \\
\hline Trees $>1 "$ Dl & & & & & & & \\
\hline
\end{tabular}




\section{Modeling Process}

Modeling of the alternatives was done in a fashion similar to the modeling procedures used by the Pacific Northwest Region and Mason, Bruce and Girard. The basic plot data was processed using data base software, with the summary tables for the alternative outputs generated by a Lotus spreadsheet.

An important difference between the modeling methods used by the BLM and the Forest Service (Pacific Northwest Region) is that the BLM modelled harvesting at the individual plot level, while the Pacific Northwest Region grouped their plots into averages per stratum and modelled harvesting at that level. While the mechanics of this may be unclear to the reader, the significance lies in the fact that the method used by the BLM is probably slightly better at determining which trees would be cut and which ones would be left. The stocking variation formed between plots is more pronounced at the plot level than at the average trees per stratum level, and thus may result in more instances where at the plot level, harvesting could not occur and still meet minimum leave tree requirements.

\section{Modeling Results}

The following tables display the results of modeling the alternatives using the inventory data from the BLM.

\begin{tabular}{|c|c|c|c|c|c|c|c|}
\hline \multicolumn{2}{|c|}{ All Bureau of Land Management (BLM) Districts } \\
\hline Alternatives & $\begin{array}{c}\text { Total Acres } \\
\text { Inventoried }\end{array}$ & $\begin{array}{c}\text { Total Number } \\
\text { of Trees on } \\
\text { Inventoried } \\
\text { Acres* }\end{array}$ & $\begin{array}{c}\text { Acres Entered } \\
\text { by this } \\
\text { Alternative } \\
\text { (next 5 yrs) }\end{array}$ & $\begin{array}{c}\text { Trees } \\
\text { Harvested by } \\
\text { this } \\
\text { Alternative } \\
\text { (next 5 yrs) }\end{array}$ & $\begin{array}{c}\text { Trees } \\
\text { Harvested by } \\
\text { this Alternative } \\
\text { (next 5 yrs) } \\
50 \%-25 \% \\
\text { reduction (M) }\end{array}$ & $\begin{array}{c}\text { Pounds of } \\
\text { Dry Bark } \\
\text { (next 5 yrs) }\end{array}$ & $\begin{array}{c}\text { Pounds of } \\
\text { Dry Bark } \\
\text { (next 5 yrs) } \\
50 \%-25 \% \\
\text { reduction (M) }\end{array}$ \\
\hline A & $2,032,678$ & $2,084,678$ & 0 & 0 & 0 & 0 & 0 \\
\hline B & $2,032,678$ & $2,084,678$ & 62,400 & 43,884 & $22-33$ & 247,102 & $124-185$ \\
\hline C & $2,032,678$ & $2,084,678$ & 680,973 & 105,157 & $53-79$ & 714,842 & $357-536$ \\
\hline D & $2,032,678$ & $2,084,678$ & 680,973 & 162,744 & $81-122$ & 922,356 & $461-692$ \\
\hline F & $2,032,678$ & $2,084,678$ & 680,973 & 255,194 & $128-191$ & $1,374,970$ & $687-1,031$ \\
\hline G1 & $2,032,678$ & $2,084,678$ & 680,973 & 218,161 & $109-164$ & $1,502,898$ & $751-1,127$ \\
\hline G2 & $2,032,678$ & $2,084,678$ & $1,406,614$ & 449,450 & $225-337$ & $3,243,270$ & $1,622-2,432$ \\
\hline${ }^{*}$ Trees $>1 "$ DBH & & \multicolumn{7}{|c|}{} & & & & \\
\hline
\end{tabular}




\begin{tabular}{|c|c|c|c|c|c|c|c|}
\hline \multicolumn{8}{|c|}{ Salem District } \\
\hline Alternatives & $\begin{array}{l}\text { Total Acres } \\
\text { Inventoried }\end{array}$ & $\begin{array}{c}\text { Total Number } \\
\text { of Trees on } \\
\text { Inventoried } \\
\text { Acres* }\end{array}$ & $\begin{array}{c}\text { Acres Entered } \\
\text { by this } \\
\text { Alternative } \\
\text { (next } 5 \text { yrs) }\end{array}$ & $\begin{array}{c}\text { Trees } \\
\text { Harvested by } \\
\text { this } \\
\text { Alternative } \\
\text { (next } 5 \text { yrs) }\end{array}$ & $\begin{array}{c}\text { Trees } \\
\text { Harvested by } \\
\text { this Alternative } \\
\text { (next } 5 \text { yrs) } \\
50 \%-25 \% \\
\text { reduction (M) }\end{array}$ & $\begin{array}{l}\text { Pounds of } \\
\text { Dry Bark } \\
\text { (next } 5 \text { yrs) }\end{array}$ & $\begin{array}{l}\text { Pounds of } \\
\text { Dry Bark } \\
\text { (next } 5 \text { yrs) } \\
50 \%-25 \% \\
\text { reduction (M) }\end{array}$ \\
\hline A & 369,912 & 340,763 & 0 & 0 & 0 & 0 & 0 \\
\hline B & 369,912 & 340,763 & 10,225 & 9,718 & $5-7$ & 33,100 & $17-25$ \\
\hline $\mathrm{C}$ & 369,912 & 340,763 & 117,058 & 29,565 & $15-22$ & 130,089 & $65-98$ \\
\hline D & 369,912 & 340,763 & 117,058 & 46,072 & $23-35$ & 182,482 & $91-137$ \\
\hline $\mathrm{F}$ & 369,912 & 340,763 & 117,058 & 72,125 & $36-54$ & 234,402 & $117-176$ \\
\hline G1 & 369,912 & 340,763 & 117,058 & 58,006 & $29-44$ & 242,076 & $121-182$ \\
\hline $\mathrm{G} 2$ & 369,912 & 340,763 & 281,029 & 125,990 & $63-94$ & 527,192 & $264-395$ \\
\hline
\end{tabular}

\begin{tabular}{|c|c|c|c|c|c|c|c|}
\hline \multicolumn{8}{|c|}{ Eugene District } \\
\hline Alternatives & $\begin{array}{l}\text { Total Acres } \\
\text { Inventoried }\end{array}$ & $\begin{array}{c}\text { Total Number } \\
\text { of Trees on } \\
\text { Inventoried } \\
\text { Acres* }\end{array}$ & $\begin{array}{c}\text { Acres Entered } \\
\text { by this } \\
\text { Alternative } \\
\text { (next } 5 \text { yrs) }\end{array}$ & $\begin{array}{c}\text { Trees } \\
\text { Harvested by } \\
\text { this } \\
\text { Alternative } \\
\text { (next } 5 \text { yrs) }\end{array}$ & $\begin{array}{c}\text { Trees } \\
\text { Harvested by } \\
\text { this Alternative } \\
\text { (next } 5 \text { yrs) } \\
50 \%-25 \% \\
\text { reduction (M) }\end{array}$ & $\begin{array}{l}\text { Pounds of } \\
\text { Dry Bark } \\
\text { (next } 5 \mathrm{yrs} \text { ) }\end{array}$ & $\begin{array}{c}\text { Pounds of } \\
\text { Dry Bark } \\
\text { (next } 5 \text { yrs) } \\
50 \%-25 \% \\
\text { reduction (M) }\end{array}$ \\
\hline A & 302,293 & 105,794 & 0 & 0 & 0 & 0 & 0 \\
\hline B & 302,293 & 105,794 & 7,850 & 2,596 & $1-2$ & 51,852 & $26-39$ \\
\hline $\mathrm{C}$ & 302,293 & 105,794 & 92,306 & 2,773 & $1-2$ & 53,927 & $27-40$ \\
\hline D & 302,293 & 105,794 & 92,306 & 2,817 & $1-2$ & 54,331 & $27-41$ \\
\hline F & 302,293 & 105,794 & 92,306 & 6,480 & $3-5$ & 211,058 & $106-158$ \\
\hline G1 & 302,293 & 105,794 & 92,306 & 11,850 & $6-9$ & 261,933 & $131-196$ \\
\hline $\mathrm{G} 2$ & 302,293 & 105,794 & 260,520 & 33,201 & $17-25$ & 686,998 & $343-515$ \\
\hline
\end{tabular}




\begin{tabular}{|c|c|c|c|c|c|c|c|}
\hline \multicolumn{8}{|c|}{ Roseburg District } \\
\hline Alternatives & $\begin{array}{l}\text { Total Acres } \\
\text { Inventoried }\end{array}$ & $\begin{array}{c}\text { Total Number } \\
\text { of Trees on } \\
\text { Inventoried } \\
\text { Acres* }\end{array}$ & $\begin{array}{c}\text { Acres Entered } \\
\text { by this } \\
\text { Alternative } \\
\text { (next } 5 \text { yrs) }\end{array}$ & $\begin{array}{l}\text { Trees } \\
\text { Harvested by } \\
\text { this } \\
\text { Alternative } \\
\text { (next } 5 \text { yrs) }\end{array}$ & $\begin{array}{l}\text { Trees } \\
\text { Harvested by } \\
\text { this Alternative } \\
\text { (next } 5 \text { yrs) } \\
50 \%-25 \% \\
\text { reduction (M) }\end{array}$ & $\begin{array}{l}\text { Pounds of } \\
\text { Dry Bark } \\
\text { (next } 5 \text { yrs) }\end{array}$ & $\begin{array}{l}\text { Pounds of } \\
\text { Dry Bark } \\
\text { (next } 5 \text { yrs) } \\
50 \%-25 \% \\
\text { reduction (M) }\end{array}$ \\
\hline A & 390,967 & 846,647 & 16,725 & 0 & 0 & 0 & 0 \\
\hline B & 390,967 & 846,647 & 139,260 & 26,920 & $13-20$ & 139,575 & $70-105$ \\
\hline C & 390,967 & 846,647 & 139,260 & 66,009 & $33-50$ & 491,762 & $246-369$ \\
\hline D & 390,967 & 846,647 & 139,260 & 105,389 & $53-79$ & 640,429 & $320-480$ \\
\hline $\mathrm{F}$ & 390,967 & 846,647 & 139,260 & 156,261 & $78-117$ & 835,959 & $418-627$ \\
\hline $\mathrm{G} 1$ & 390,967 & 846,647 & 139,260 & 124,972 & $62-94$ & 871,870 & $436-654$ \\
\hline $\mathrm{G} 2$ & 390,967 & 846,647 & 309,648 & 242,255 & $121-182$ & $1,762,387$ & $881-1,322$ \\
\hline
\end{tabular}

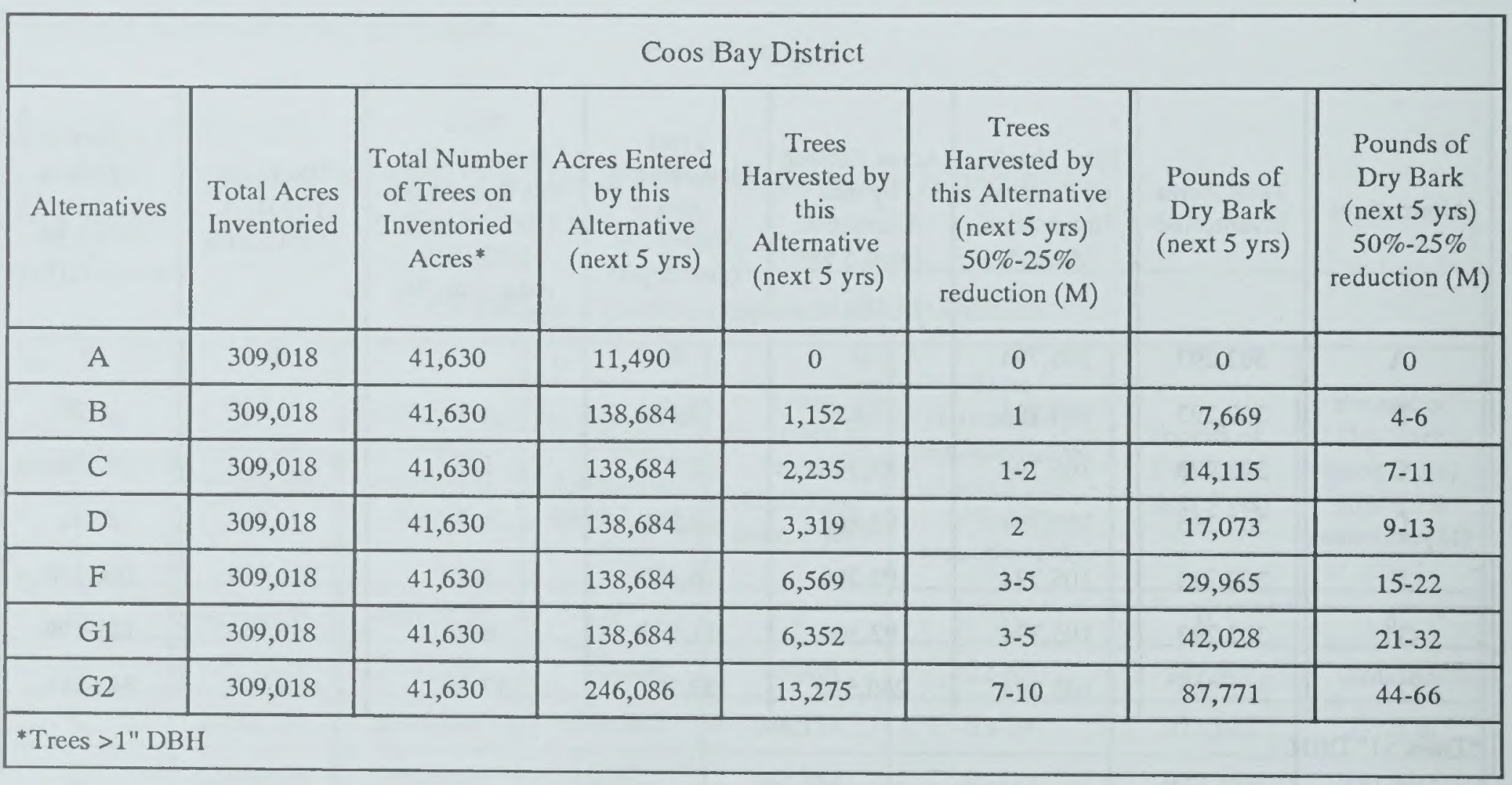




\begin{tabular}{|c|c|c|c|c|c|c|c|}
\hline \multicolumn{8}{|c|}{ Medford District } \\
\hline Alternatives & $\begin{array}{l}\text { Total Acres } \\
\text { Inventoried }\end{array}$ & $\begin{array}{c}\text { Total Number } \\
\text { of Trees on } \\
\text { Inventoried } \\
\text { Acres* }\end{array}$ & $\begin{array}{c}\text { Acres Entered } \\
\text { by this } \\
\text { Alternative } \\
\text { (next } 5 \text { yrs) }\end{array}$ & $\begin{array}{c}\text { Trees } \\
\text { Harvested by } \\
\text { this } \\
\text { Alternative } \\
\text { (next } 5 \text { yrs) }\end{array}$ & $\begin{array}{l}\text { Trees } \\
\text { Harvested by } \\
\text { this Alternative } \\
\text { (next } 5 \text { yrs) } \\
50 \%-25 \% \\
\text { reduction (M) }\end{array}$ & $\begin{array}{l}\text { Pounds of } \\
\text { Dry Bark } \\
\text { (next } 5 \text { yrs) }\end{array}$ & $\begin{array}{c}\text { Pounds of } \\
\text { Dry Bark } \\
\text { (next } 5 \text { yrs) } \\
50 \%-25 \% \\
\text { reduction (M) }\end{array}$ \\
\hline A & 612,424 & 743,319 & 16,110 & 0 & 0 & 0 & 0 \\
\hline B & 612,424 & 743,319 & 157,669 & 3,498 & $2-3$ & 14,905 & $7-11$ \\
\hline $\mathrm{C}$ & 612,424 & 743,319 & 157,669 & 4,574 & $2-3$ & 24,949 & $12-19$ \\
\hline $\mathrm{D}$ & 612,424 & 743,319 & 157,669 & 5,148 & $3-4$ & 28,041 & $14-21$ \\
\hline F & 612,424 & 743,319 & 157,669 & 13,759 & $7-10$ & 63,588 & $32-48$ \\
\hline G1 & 612,424 & 743,319 & 157,669 & 16,981 & $8-13$ & 84,993 & $42-64$ \\
\hline $\mathrm{G} 2$ & 612,424 & 743,319 & 273,335 & 34,729 & $17-26$ & 178,922 & $89-134$ \\
\hline
\end{tabular}

\begin{tabular}{|c|c|c|c|c|c|c|c|}
\hline \multicolumn{8}{|c|}{ Lakeview District } \\
\hline Alternatives & $\begin{array}{l}\text { Total Acres } \\
\text { Inventoried }\end{array}$ & $\begin{array}{c}\text { Total Number } \\
\text { of Trees on } \\
\text { Inventoried } \\
\text { Acres* }\end{array}$ & $\begin{array}{c}\text { Acres Entered } \\
\text { by this } \\
\text { Alternative } \\
\text { (next } 5 \text { yrs) }\end{array}$ & $\begin{array}{c}\text { Trees } \\
\text { Harvested by } \\
\text { this } \\
\text { Alternative } \\
\text { (next } 5 \text { yrs) }\end{array}$ & $\begin{array}{l}\text { Trees } \\
\text { Harvested by } \\
\text { this Alternative } \\
\text { (next } 5 \text { yrs) } \\
50 \%-25 \% \\
\text { reduction (M) }\end{array}$ & $\begin{array}{l}\text { Pounds of } \\
\text { Dry Bark } \\
\text { (next } 5 \text { yrs) }\end{array}$ & $\begin{array}{c}\text { Pounds of } \\
\text { Dry Bark } \\
\text { (next } 5 \text { yrs) } \\
50 \%-25 \% \\
\text { reduction (M) }\end{array}$ \\
\hline A & 48,064 & 6,525 & 0 & 0 & 0 & 0 & 0 \\
\hline B & 48,064 & 6,525 & 0 & 0 & 0 & 0 & 0 \\
\hline $\mathrm{C}$ & 48,064 & 6,525 & 0 & 0 & 0 & 0 & 0 \\
\hline D & 48,064 & 6,525 & 0 & 0 & 0 & 0 & 0 \\
\hline $\mathrm{F}$ & 48,064 & 6,525 & 0 & 0 & 0 & 0 & 0 \\
\hline G1 & 48,064 & 6,525 & 0 & 0 & 0 & 0 & 0 \\
\hline G2 & 48,064 & 6,525 & 0 & 0 & 0 & 0 & 0 \\
\hline
\end{tabular}




\section{State and Private Lands}

State and private lands are not included in the management area covered by this EIS. However, this information is presented as an additional resource and for comparison with inventory data from public lands.

Congress has mandated that the Forest Service supplement its own and other federal agencies' inventories with estimates of natural resources on state and private lands. In the Pacific Northwest Region, these inventories are performed by the Forest Inventory and Analysis Group (FIA) of the Pacific Northwest Research Station (PNW). The inventories are ongoing low-intensity samples that include many different species, including Pacific yew.

The following table shows the number of yew trees that are estimated to exist on state and private lands in California, Oregon, and Washington.

\begin{tabular}{|c|c|c|c|c|c|c|}
\hline \multicolumn{7}{|c|}{ Number of Pacific Yew on State and Private Lands in California, Oregon, and Washington } \\
\hline \multirow{2}{*}{ Location } & \multicolumn{6}{|c|}{ Diameter Class } \\
\hline & 1.0-4.9 & $5.0-10.9$ & $11.0-14.9$ & $15.0-20.9$ & $21.0+$ & Total \\
\hline \multicolumn{7}{|l|}{ California: } \\
\hline North Coast & 0 & 984,000 & 0 & 0 & 12,000 & 996,000 \\
\hline Sacramento & 792,000 & 191,000 & 56,000 & 0 & 0 & $1,039,000$ \\
\hline Total & 792,000 & $1,175,000$ & 56,000 & 0 & 12,000 & $2,035,000$ \\
\hline \multicolumn{7}{|l|}{ Oregon: } \\
\hline Northwest & $1,133,000$ & 68,000 & 182,000 & 0 & 0 & $1,383,000$ \\
\hline West Central & 681,000 & 98,000 & 145,000 & 54,000 & 0 & 978,000 \\
\hline Southwest & $1,030,000$ & 289,000 & 152,000 & 0 & 0 & $1,471,000$ \\
\hline Blue Mountains & 131,000 & 266,000 & 0 & 0 & 0 & 397,000 \\
\hline Total & $2,975,000$ & 721,000 & 479,000 & 54,000 & 0 & $4,229,000$ \\
\hline \multicolumn{7}{|l|}{ Washington: } \\
\hline Puget Sound & $2,179,000$ & 513,000 & 34,000 & 0 & 0 & $2,726,000$ \\
\hline Olympic Peninsula & 601,000 & 369,000 & 50,000 & 0 & 0 & $1,020,000$ \\
\hline Total & $2,780,000$ & 882,000 & 84,000 & 0 & 0 & $3,746,000$ \\
\hline Total All Three States & $6,547,000$ & $2,770,000$ & 619,000 & 54,000 & 12,000 & $10,010,000$ \\
\hline
\end{tabular}




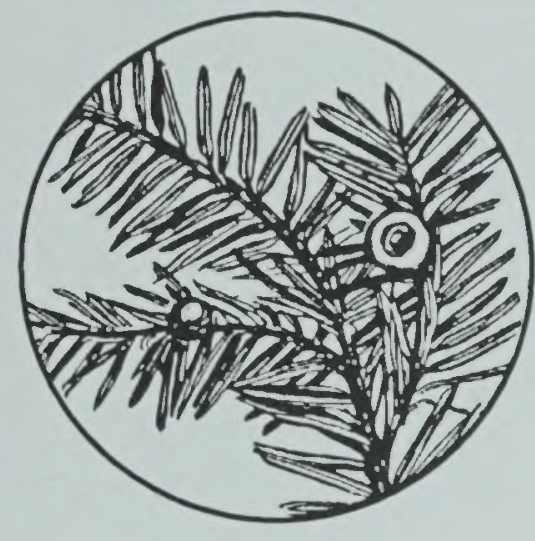

\section{Appendix G}

Insects and Diseases of Pacific Yew 


\section{Changes Made Since the Draff EIS}

\section{Appendix $\mathrm{G}$}

No Changes. 
Information on arthropods and plant diseases found on any of the seven known species of the genus Taxus is scarce and widely scattered in the literature; as scattered as the various species of yew.

Based upon a brief review of the world literature on Taxus, it is Insects suggested that the following types of arthropods are likely to be found:

- Gall-forming mites (Eriophyidae) and flies (Cecidomyiidae)

- Taxomyia taxi, artichoke gall midge

- Cecidophyopsis psilaspis. Taxis bud mite

- Nalepella tsugifoliae, a needle-feeding mite of hemlock, is also found on yew

- Root-weevils (Curculionidae)

-- Nemocestes incomptus, woods weevil

-- Otiorhynchus ovatus, strawberry root weevil

-- O. rugosostriatus, rough strawberry root weevil

-- O. rugifrons

-- O. sulcatus, black vine weevil '(taxus weevil)

-- Sciopithes obscurus, obscure root weevil

- Foliage feeders (Scarabaeidae, Curcolionidae, Torticidae)

- Mealybugs (Pseudococcidae)

-- Dysmicoccus wistariae, Taxus mealybug

-- Pseudococcus affinis, obscure mealybug

-- P. comstocki, Comstock mealybug

-- P. longispinus, longtailed mealybug

-- P. maritimus, grape mealybug

- Scales (Coccidae, Diaspididae)

-- Aspidiotus nerii, oleander scale

-- Chrysomphalus dictyospermi, dictyospermum scale

-- Fiorinia externa, elongate hemlock scale

-- Parthenolecanium fletcheri, Fletcher scale

-- Pseudaulacaspis cockerelli, false oleander scale

-- Pulvinaria floccifera, cottony Taxus scale

-- Aonidiella taxus, the Asiatic red scale 


\section{Diseases}

\section{Root Diseases}

Diseases of Pacific yew have not been studied or reported in detail, but yew seedlings in the eastern United States have been damaged by the following root-infecting fungi:

-- Rhizoctonia solani, damping-off

-- Phytophthora cinnamomi, Phytophthora root rot

-- Pythium species, damping-off

Older yew trees in the west have been reported as hosts for:

-- Armillaria spp., Armillaria root disease

-- Phaeolus schweinitzii, Schweinitzii butt rot

-- Phytophthora lateralis, Port-Orford-cedar root disease

\section{Stem Decays}

Several species of fungi causing decay of the heartwood have been identified in Pacific yew:

-- Phellinus nigrolimitatus, big white pocket rot

-- $P$. robustus, robustus trunk rot

-- P. pini, red ring rot

-- Fomitopsis rosea, brown top rot

\section{Foliage Diseases}

Several species of blight fungi have caused localized damage to Pacific yew foliage that has remained under snow for long periods of time:

-- Neopeckia coulteri, brown felt blight

-- Herpotrichia juniperi, brown felt blight

-- Phacidium taxicolum, snow blight

-- Phacidium dearnessii, snow blight

The following fungi, causing needle blights of yew, have been reported:

-- Asteridiella pitya, black mildew

-- Dothiora taxicola, needle-and shoot-blight

-- Macrophoma taxi, yew leaf blight

-- Mycosphaerella taxi, (Septoria)

-- Sphaerulina taxi, yew leaf scorch (Sphaerulina taxi causes the upper surface of the needle to become brown, giving the foliage a scorched appearance) 


\section{Stem Cankers}

A few stem- or twig-infecting fungi, causing stem cankers, have been reported on Pacific yew:

-- Phyllostictina hystrella, shoot and leaf blight

-- Diplodia taxi 



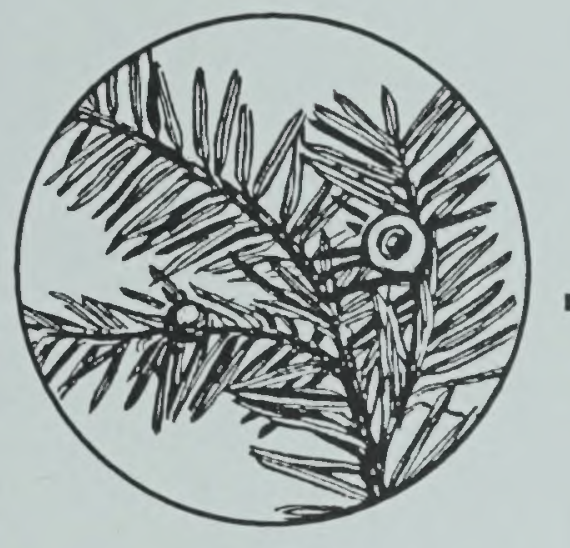

\section{Appendix H \\ Pacific Yew Plant Associations}




\section{Changes Made Since the Draff EIS Appendix $\mathrm{H}$}

Added "Vegetation" subsections from Chapter III-Part Two, "Physiographic Provinces" section.

Added Figure III-6, "Potential Natural Vegetation Types" illustration from the above mentioned section in Chapter III.

Added sections about vegetation on Mt. Baker-Snoqualmie, and the Blue Mountains. 


\section{Appendix $\mathrm{H}$}

\section{Plant Associations}

\section{Table of Contents}

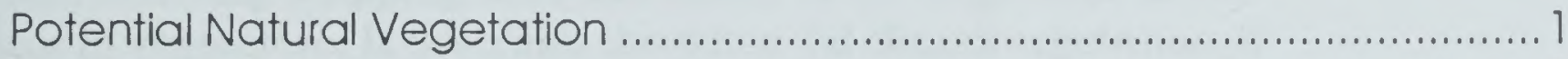

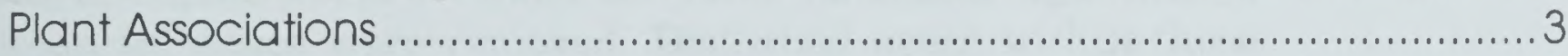

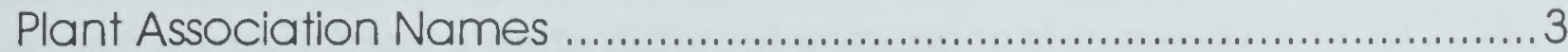

Plant Associations Containing Yew .................................................. 4

Plant Associations Where Yew Is Found ............................................. 5

Yew Occurrence- more detailed information

in three physiographic provinces

Distribution and Habitat of Pacific Yew in Northern Sierra Nevada and

Southern Cascades of California ................................................... 8

Distribution and Habitat of Pacific Yew in The

Mt. Baker-Snoqualmie and Olympic National Forests ..................... 9

Distribution and Habitat of Pacific Yew in The

Blue and Wallowa Mountains .................................................. 12

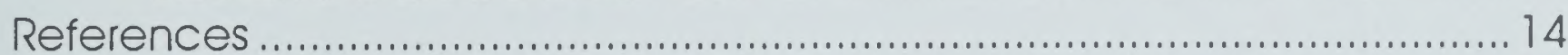

References_Plant Associations Guides ............................................. 15 

The vegetation types found within the five-state region covered by the EIS are extremely variable. The following discussion assesses broad vegetational trends. More detailed information on vegetation types for each National Forest and BLM District can be found in the plant association/habitat type guides for each area.

Vegetation changes over time and with disturbances; any mapping of vegetation types over large acreages will therefore require a certain degree of generalization. Figure $\mathrm{H}-1$ is a map of the potential natural vegetation types of the area covered by the EIS (Kuchler, 1964). This is one of the most commonly used large scale classifications of vegetation. Kuchler's vegetation types are very broad, allowing mapping that can easily show large scale differences in vegetation. It describes the potential climax vegetation, if human influence were removed. Disturbed areas within these classes may actually have a quite different vegetational composition. (See also the Society of American Foresters "Forest Cover Types of the United States and Canada" (1980) for a classification that is based on existing, rather than potential, forest cover.)

\section{Potential Natural Vegetation}




\section{Plant}

\section{Associations}

\section{Figure H-1: Potential Natural Vegetation Types}

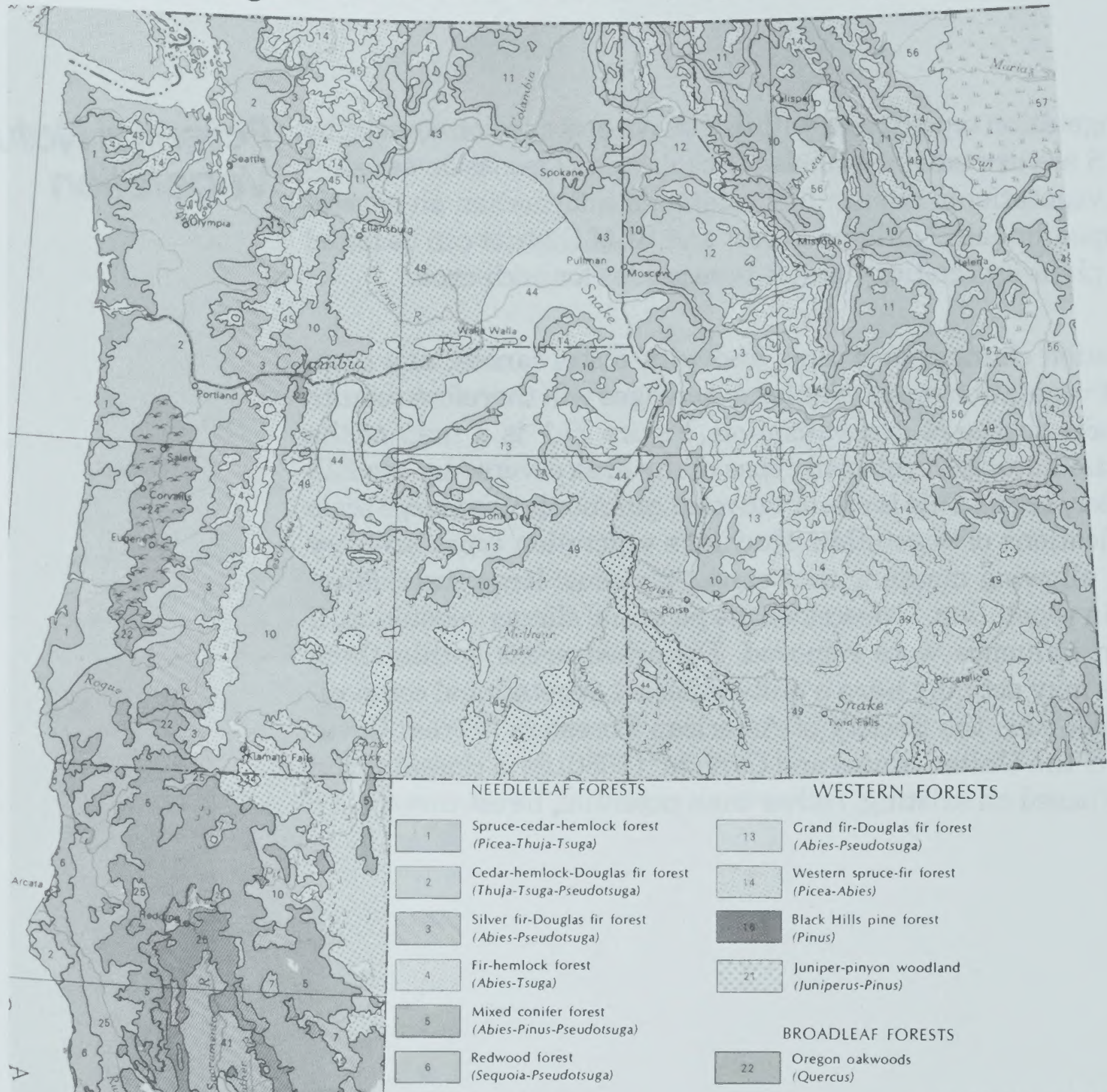

BROADLEAF AND NEEDLELEAF FORESTS

( 2 Lodgepole pine-subalpine forest

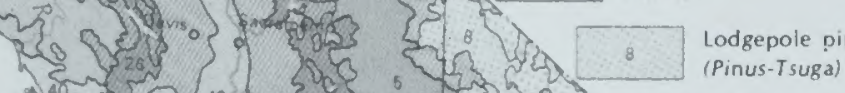

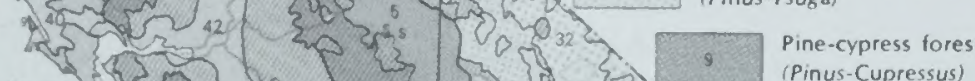

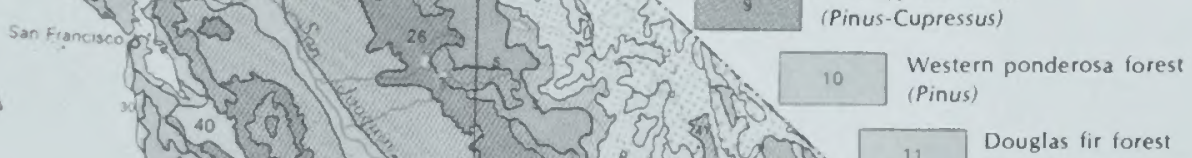

3 (P)

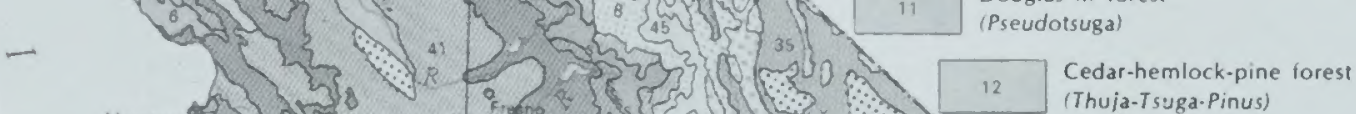

SHRUB
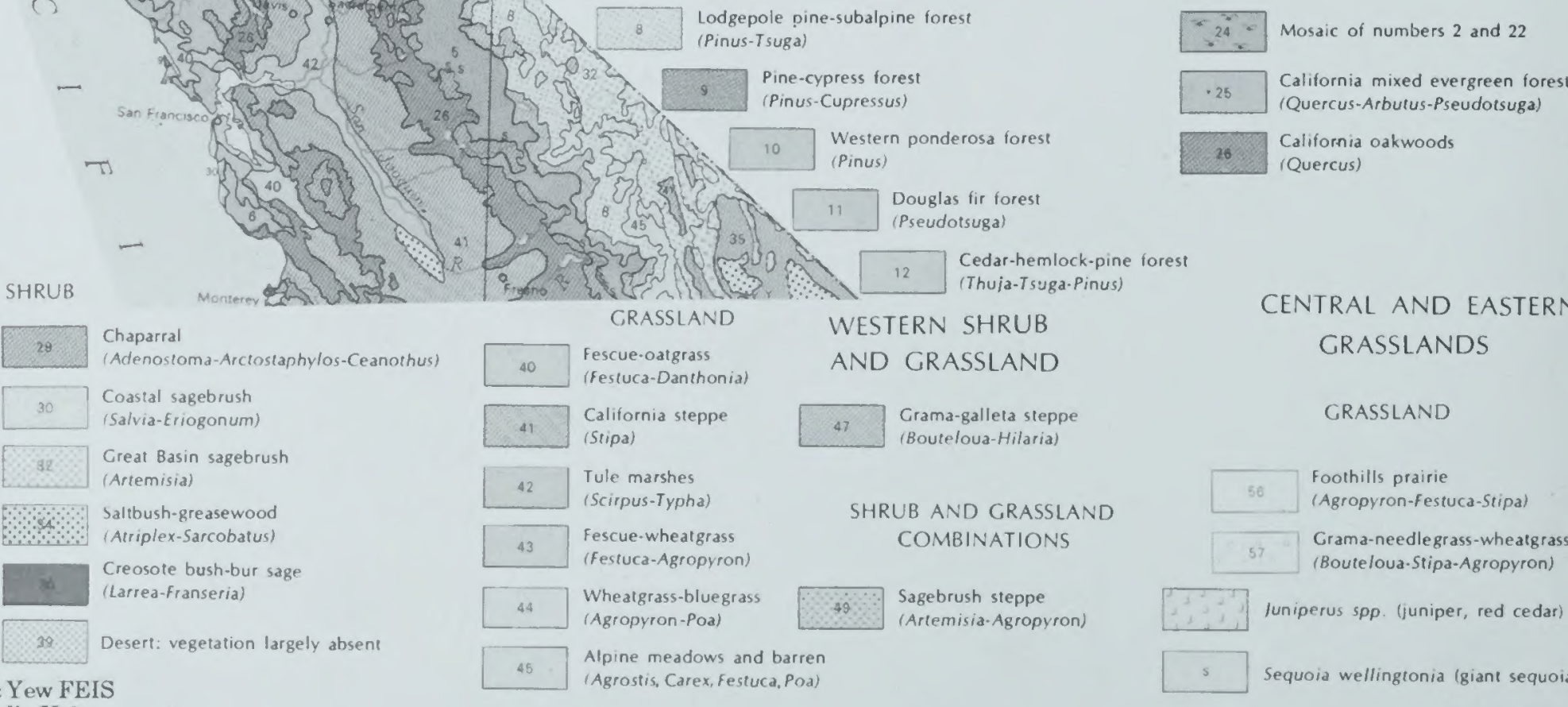

Pacific Yew FEIS

Appendix $\mathrm{H}-2$ 
The plant association (or habitat type) concept is a more detailed classification of vegetation. Plant associations are groupings of plant species that recur across the landscape within particular environments (Daubenmire, 1968). Plant associations describe the potential, or climax, plant community, the vegetation that would eventually occupy a site in the absence of disturbance. They describe the community that would become established if all successional sequences were completed without interference by humans or natural fire, under present environmental conditions. Plant associations are classified not only by the climax tree species on a site, but also by the shrub and herbaceous vegetation.

The group of species that eventually becomes dominant on a site is an indicator of environmental conditions. The classification of sites into plant association types allows us to make inferences about a wide range of ecosystem functions and responses, simply by examining the vegetation.

A stand does not have to be in a climax condition to classify the plant association type. The plant association concept relates to environmental conditions that determine where a species could be climax and where it could not.

\section{Plant Association Names}

Plant associations are named after the climax tree species and the shrub or herbaceous species that typify the association. Species codes are derived from the first two letters of the genus name and the first two letters of the species name. For example, Pacific yew (Taxus brevifolia) is coded Tabr. Life forms (trees, shrubs, herbs) are separated by slashes in the plant association name, and species of the same life form are separated by dashes. Examples: The western hemlock/Pacific rhododendron/Oregon oxalis (Tsuga heterophylla/Rhododendron macrophyllum / Oxalis oregana) association is coded Tshe/Rhma/Oxor. The western hemlock/Pacific rhododendron-salal (Tsugaheterophylla / Rhododendron macrophyllum-Gaultheria shallon) association is coded Tshe/Rhma-Gash.

\section{Plant
Associations \\ Associations}


Pacific yew is extremely variable in growth form, in taxol content, and in the environmental settings in which it grows. It follows that the species should be present in an extremely large number of plant associations. In western Oregon, yew trees or shrubs can be found somewhere in almost every dry land forest plant association, although in some cases yews may occupy microsites that should not be considered part of the general association surrounding them.

Yew also occurs in some areas that could be classified as nonforest: avalanche chutes in which yew shrubs form dense thickets (Deevy, 1991), chaparral-like thickets of yew shrubs in the mountains of northern Montana, talus and scree slopes in which yew is the only tree present, and rocky cliffs. A parallel to the latter is Taxus baccata which grows on chalk cliffs in Cumbria in the British Isles (Bolsinger, 1988-91; Hartzell, 1991).

In the Dog Island National Recreation Area of coastal Alaska, Pacific yew occurs at sea level in boggy sites in association with Alaska cedar, mountain hemlock, western hemlock, and shore pine. This seems entirely uncharacteristic; yew seems to shun poorly drained soil elsewhere (Alaback and Juday, 1989).

Inventory plots on non-federal lands in Oregon and Washington show Pacific yew growing in 35 plant associations. In national forests in Oregon and Washington, excluding the Rogue River, Siskiyou, and Umpqua National Forests in southwest Oregon, Forest Service ecologists found yew in 35 plant associations, including some found on non-federal lands.

Yew occurred in 40 plant associations on the Siskiyou and west half of the Rogue River National Forests, and in 40 plant associations on the Umpqua and east half of the Rogue River National Forests. Yew occurred in eight plant associations in the Blue Mountains, nine associations in the Sierra Nevada and southern Cascades of California, and in 10 plant associations in the Oregon Coast range. On inventory plots on non-federal lands in northern California, yew was found in seven plant associations. Yew was observed on the Six Rivers National Forest in an additional association.

In Idaho and Montana, Pacific yew is found in 29 associations (terminology differs between regions; associations in Region Six are equivalent to series/habitat type/phase in Region One).

\section{Plant \\ Associations Containing Yew}


Abgr/Asca/Mefe

Abgr/Asca/Tabr

Abgr/Clun

Abgr/Libo

Abgr/Setr

Abgr/Xete
Abla/Clun/Vaca

Abla/Clun/Xete

Abla/Libo/Xete

Abla/Opho

Pien/Clun

Pien/Clun/Vaca
Thpl/Cl Thpl/M Thpl/Op Tshe/As $\mathrm{Tshe} / \mathrm{Cl}$ $\mathrm{Tshe} / \mathrm{Cl}$ Tshe/Gy

\section{Plant Associations With Yew Present}

on Non-federal Lands in Northern California $\mathrm{Abco} / \mathrm{Acma} / \mathrm{Acci}$ Chla $\mathrm{Abco/Lide/Chfo}$ Psme/Lide/Quch Abco/Lide/Chum Sese/Pomu

Plant Associations With Yew Present in Western Or Washington North of the Umpqua National Forest (National Forests and non-Federal lands)

Abam-Abgr/Smst Psme/Hodi/Whmo

Abam/Actr-Clun

Abam/Bene

Abam/Gash

Abam/Mefe

Abam/Tiun

Abam/Vaal-Gash

Abam/Vame/Clun

Abgr/Bene

Psme/Bene

Psme/Gash

Psme/Hodi/Grass
Tshe/Actr

Tshe/Bene

Tshe/Bene/Actr

Tshe/Bene-Gash

Tshe/Bene/Oxor

Tshe/Conu/Actr

Tshe/Gash

Tshe/Libo2

Tshe/Opho

Tshe/Opho/Pomu

Tshe/Oxor
Tshe/Po Tshe/Po Tshe-Ps Tshe/Rh Tshe/Rh Tshe/Rh Tshe/Rh Tshe/Rhi Tshe/Rh Tshe/Tit Tshe/Va 
Plant Associations With Yew Present in Mount Rainier National Park

$\begin{array}{lll}\text { Moist Sites } & \begin{array}{l}\text { Dry Sites } \\ \text { Abam/Bene Cold Sites }\end{array} \\ \text { Abam phase } & \text { Abam/Rula-Rulaphase } \\ \text { Abam/Opho } & \text { Abam/Xete-Tshe phase } \\ \text { Abam/Tiun - Climax phase } & \text { Psme/Vise } \\ \text { Slope phase } & \text { Tshe/Gash } \\ \text { Valley phase } & \\ \text { Tshe phase } & \\ \text { Tshe/Actr } & \\ \text { Tshe/Opho } & \\ \text { Tshe/Pomu } & \end{array}$

Plant Associations with Yew Present in the Blue Mountains (of Northeastem Oregon)
Abgr/Acgl
Abgr/Libo2
Abgr/Tabr/Libo2
Abgr/Clun
Abgr/Pomu-Asca3
Abgr/Trca3
Abgr/Gydr
Abgr/Tabr/Clun

Plant Associations With Pacific Yew Present in the Umpqua and East Half of the Rogue River National Forests (Southern Oregon Cascades Geological province)
Abam/Acci/Titr
Psme/Rhdi
Tshe/Gash/Libol
Abam-Thpl/Runi
Psme/Runi/Actr
Tshe/Gash/Oxor
Abam-Tshe
Psme/Tshe-Acci
Tshe/Gash/Pomu
Abco-Tsme
Psme/Vame/Actr
Tshe/Pimo/Vame
Psme/Abam
Thpl-Tshe/Rhma
Tshe/Rhma/Libol
Psme-Abmas/Bene
Thpl-Tshe/Whmo
Tshe/Tabr/Rhma
Psme/Acci/Actr
Tshe-Abam
Tshe-Thpl/Bene
Psme/Acgl/Bene
Tshe/Acci-Alru
Tshe-Thpl/Conu
Psme/Amal/Ande
Tshe/Acgl/Smst
Tshe-Thpl/Oxor
Psme/Bene-Gash
Tshe/Bene/Actr
Tshe-Thpl-Psme
Psme/Bene/Pomu
Tshe/Bene/Libol
Tshe-Thpl/Rhma
Psme/Cade3/Bene
Tshe/Bene/Oxor
Tshe/Vame/Oxor
Psme/Chumn/Libol
Tshe/Cade3/Rhma/Clun
Psme/Psme/Bepi
Tshe/Gash/Hial 
Plant Association With Pacific Yew Present in the Siskiyou and West Half of the Rogue River National Forests (Klamath Geological Province)
Abam-Acci/Titr
Abco-Tshe-Acci
Tshe-Pimo/Vame
Abam-Tshe
Abco/Vame/Actr
Tshe/Rhma/Libol
Abco-Abam
Psme/Bene/Pomu
Tshe-Tabr/Rhma
Abco-Abmas/Bene
Psme/Gash/Pomu
Tshe-Thpl/Bene
Abco/Acci/Actr
Tshe-Abam
Tshe-Thpl/Conu
Abco-Acgl/Bene
Tshe-Acci-Alru
Thse-Thpl/Oxor
Abco/Amal/Ande
Tshe-Acgl/Smst
Tshe-Thpl-Psme
Abco/Bene-Gash
Tshe/Bene/Actr
Tshe-Thpl/Runi
Abco-Cade3/Bene
Tshe/Bene/Libol
Tshe-Thpl/Rhma
Abco/Chumn/Libol
Tshe/Bene/Oxor
Thpl-Tshe/Rhma
Abco-Psme/Bepi
Tshe-Cade3/Rhma/Clun Thpl-Tshe/Whmo
Abco/Rhdi
Tshe/Gash/Hial
Tshe/Vame/Oxor
Abco/Runi/Actr
Tshe/Gash/Libol
Abco-Tabr
Tshe/Gash/Oxor

Plant Associations with Pacific Yew in the Northem

Sierra Nevada and Southem Cascades of California

Mcn-Acma/Adbi

$\mathrm{Mcn} / \mathrm{Cococ} / \mathrm{Adbi}$

Men-Lide2/Cococ

$\mathrm{Mcn}-\mathrm{Acma} / \mathrm{Cococ}$

Mcn-Conu2/Adbi/DiHo2 Mcn-Lide2-Conu2

Men/Adbi

Men-Conu2/Cococ

Mcn-Lide2-Conu2/Cococ

Plant Associations with Pacific Yew Present in the Oregon

\section{Coast Range}

Pisi/Oxor

Tshe/Bene-Gash

Tshe/Rhma-Vaov2

Pisi/Rusp-Gash

Tshe/Oxor

Tshe/Vaov2

Tshe/Acci-Gash

Tshe/Rhma-Bene

Tshe/Bene

Tshe/Rhma/Pomu 


\section{Yew \\ Occurrence- more detailed information in three physiographic provinces}

\section{Distribution and Habitat of Pacific yew in Northern Sierra Nevada and Southern Cascades of California (Fites, 1992)}

Pacific yew occurs in scattered locations throughout the central and northern Sierra Nevada and southern Cascade mountains in California. This summary of the distribution and habitat of the Pacific yew is restricted to the Eldorado, Tahoe, Plumas, and Lassen National Forests, where ecology plot data was collected to classify mixed conifer forests. Obligate riparian vegetation was generally not sampled as part of this classification effort.

Within this geographic area, Pacific yew occurs primarily within the mixed conifer zone, between 3,000 and 5,000 feet. Trees were found in several plant associations including Mcn-Lide2-Conu2/ Cococ, Mcn-Lide2-Conu2, Mcn-Acma / Cococ, Mcn-cma/Adbi, McnConu2/Cococ, Mcn-Conu2/Adbi-Diho2, and Mcn/Cococ/Adbi. In addition, Pacific yew seedlings or saplings but not trees, were also found in the following plant associations: Mcn-Lide2 / Cococ and Mcn/Adbi. All of these plant associations occur on wet or moist sites, typically with moderately deep to deep soils. Soils are typically fine textured. Sites tend to be north or east-facing, and on lower slopes or near or at drainages. All of the primary indicator species indicate high moisture conditions. In this area, Lide2 indicates high precipitation, Acma indicates high surface or subsurface water, Conu2 indicates moist soils and cooler, moist air, Cococ indicates the same as Conu2 but tends to occur more specifically near running water, and $A d b i$ indicates moist soils. The highest frequencies of Pacific yew are in the Mcn-Lide2Conu2 (41 percent) and Mcn-Conu2 / Cococ (62 percent), suggesting that moist but well drained soils are characteristic. Most of these plant associations have a high proportion of Douglas-fir in the tree layers, further indicating a tendency toward the moister, cooler environments in the mixed conifer zone.

The habitat of Pacific yew in the northern Sierras and southern Cascades can be characterized by its plant community affiliations as: moist to wet soils, cool and humid air, and typically northfacing lower slopes or drainages. Seedlings are sometimes observed on mid-slopes, but not trees, indicating less suitable habitat. 
The highest densities of Pacific yew have been observed on finetextured alluvial soils, and on flat alluvial terraces or benches. In the northern Sierra Nevada and southern Cascades, Pacific yew is almost always associated with riparian environments, occurring near or at water sources. When the plant associations occur near seasonal, or more commonly year-around water sources, Pacific yew is often present. The Mcn-Conu2/Cococ has the highest frequency of Pacific yew and usually occurs near or at water sources. It seems likely that the other plant associations are not obligate riparian plant communities, but their affiliation with moist, cool, humid environments results in their common occurrence in these areas. Other sites away from riparian environments can also provide sufficient combinations of these factors for the common species in these plant associations but typically not Pacific yew.

One other factor that is important in characterizing the habitat of Pacific yew in California is that it is considered somewhat of a relic species. Some of its limited distribution may be explained by the past constriction of its distribution under different climatic conditions of earlier geologic eras.

\section{Distribution and Habitat of Pacific yew in The Mt. Baker-Snoqualmie and Olympic National Forests (Johnson, 1992)}

Pacific yew is widely distributed throughout the Mt. BakerSnoqualmie National Forest. However it is never abundant nor does it form pure stands. It is an understory tree in the forest communities where it occurs, and most typically occurs at a density of only a few stems per acre. It is rare to find it as a tree greater than 6 inches in diameter at breast height (DBH). It often shows signs of browsing by deer. Tables 1,2 , and 3 summarize the distribution of yew (TABR) on the Mt. Baker-Snoqualmie and Olympic National Forests. Pacific yew occurred on $16 \%$ of the Ecology Program field plots on the Mt. Baker-Snoqualmie National Forest and $11 \%$ of the plots on the Olympic National Forest. It was most frequent in the Western Hemlock (TSHE) and Douglas-fir (PSME) Series on both forests. It was less common in the Silver FIR Series and almost absent (4 plots out of 630) in the Mountain-Hemlock (TSME) Series. 
Yew (TABR) is most common on the drier western hemlock types such as Western Hemlock/Oregon grape (TSHE/BENE), Western Hemlock/Salal-Big Huckleberry (TSHE/GASH-VAME) and Western Hemlock/Salal-Oregon grape (TSHE/GASH-BENE) associations on the Mt. Baker-Snoqualmie National Forest Western Hemlock/Salal-Beargrass (TSHE/GASH-XETE) and Western Hemlock/Rhododendron-Salal (TSHE/RHMA-GASH) association on the Olympic National Forest. In the Silver Fir Series it is more common in the Silver Fir/Alaska Huckleberry-False-Lily-of-TheValley (ABAM/VAAL-MAD12) and Silver Fir/Alaska HuckleberryDepauperate (ABAM/VAAL-Dep.) associations on the Mt. BakerSnoqualmie National Forest and on the Silver Fir/RhododendronAlaska Huckleberry (ABAM/RHMA/VAAL) association on the Olympic National Forest.

Yew is most common at elevations from 1,000 to 3,000 feet on the Olympic National Forest and 1,500 to 3,500 feet on the Mt. BakerSnoqualmie National Forest. Yew shows a higher frequency on southerly and southwesterly aspects on both forests. Its relation to the two moisture-related variables (Topographic moisture and Environmental Zone) shows that yew occurs most frequently on mesic microsites (Topographic Moisture 4-6) and in the mesic to drier areas of the Forests (Environmental Zones 8-10).

Therefore, even though yew is widely distributed on both of these Forests, it is much more likely to occur in certain microsites and in certain areas than in others. It also shows a marked preference for some associations and appears to avoid others altogether. From the above figures and tables it is therefore possible to develop an environmental profile for yew on these national forests. It would also be possible to generate a map using Geographic Information System (GIS) technology, which would predict the most likely areas and the least likely areas for yew from these data. 
Table 1. Total Number of Plots in Ecology Database used in analysis.

\begin{tabular}{|c|c|c|c|}
\hline Series & Olympic NF & $\begin{array}{c}\text { Mt. Baker- } \\
\text { Snoqualmie NF }\end{array}$ & Total \\
\hline PISI & & 63 & 63 \\
\hline PSME & 48 & 4 & 52 \\
\hline TSHE & 772 & 757 & 1529 \\
\hline ABAM & 416 & 879 & 1295 \\
\hline TSME & 67 & 563 & 630 \\
\hline ABLA2 & 34 & 10 & 44 \\
\hline Total & 1400 & 2213 & 3613 \\
\hline
\end{tabular}

Table 2. Number of Plots Sampled with Yew (TABR)

\begin{tabular}{|c|c|c|c|}
\hline Series & Olympic NF & $\begin{array}{c}\text { Mt. Baker- } \\
\text { Snoqualmie NF }\end{array}$ & Total \\
\hline PISI & 1 & 0 & 1 \\
\hline PSME & 6 & 1 & 7 \\
\hline TSHE & 103 & 188 & 291 \\
\hline ABAM & 38 & 154 & 192 \\
\hline TSME & 2 & 2 & 4 \\
\hline ABLA2 & 0 & 1 & 1 \\
\hline Total & 150 & 346 & 496 \\
\hline
\end{tabular}


Table 3. Percent of Plots Sampled with Yew (TABR)

\begin{tabular}{|c|c|c|c|}
\hline Series & Olympic NF & $\begin{array}{c}\text { Mt. } \\
\text { Baker-Snoqualmie } \\
\text { NF }\end{array}$ & Total \\
\hline PISI & 2 & 0 & 2 \\
\hline PSME & 13 & 25 & 13 \\
\hline TSHE & 13 & 25 & 19 \\
\hline ABAM & 9 & 18 & 15 \\
\hline TSME & 3 & 0 & 1 \\
\hline ABLA2 & 0 & 10 & 2 \\
\hline Total & 40 & 78 & 52 \\
\hline
\end{tabular}

\section{Distribution and Habitat of Pacific yew in The Blue and Wallowa Mountains (Henderson, 1992)}

Pacific yew (Taxus brevifolia) is sporadically distributed in small, isolated clumps and individually at moderate elevations in the northern Blue and Wallowa Mountains. Its maintenance as a viable species is defined by climatic conditions, ungulate usage and harvest practices. Cool, moist environments coupled with stability from disturbances have promoted the most productive and populous stands in the intermountain Pacific northwest.

Yew is often confined to canyon bottoms, lower slope positions or favorable cove and basin settings at the head of drainages in the Blue and Wallowa Mountains. It is more commonly a mid to tall shrub-like tree which may be the result of temporal changes to individual plants, response to browsing pressure, or environmental or genetic factors. Animals can influence the quality and quantity of yew trees in these older stands. The attraction of a spring or intermittent water source to browsing ungulates has resulted in severe hedging and even elimination of yew from sites 
where it is capable of growing. The yew component to tall coniferous forests adds a compositional and structural diversity which, in turn, influences the abundance and degree of wildlife diversity. Riparian yew communities provide shading of streams, streambank stability, and improved habitat for stream inhabitants.

Pacific yew is also damaged by heat, exposure to sun, wind, frost and freezing temperatures, when the protective tall-tree overstory is removed. Where it grows optimally in its range, the trees are often resilient and respond favorably to partial overstory removals. However, in the sites where the species is growing at the limit of its environmental tolerance, the removal of the protective overstory often results in a shock which is too great for the yew trees to sustain.

A very conservative management approach is needed in harvesting products from the yew tree and the associated forest stand in the Blue and Wallowa Mountains, for the following reasons:

- The distribution of yew stands is limited;

- Yew plants are pressured by a growing population of wild browsing animals;

- The species here are at the limits of its range in a fickle climate;

- The yew is an important component of ecosystem health in the Blue and Wallowa Mountains. 
Alaback, Paul B. and G.P. Juday. 1989. Structure and composition of low-elevation old growth forests in research natural areas of southeast Alaska. Nat. Areas J. 9(1): 27-39.

Bolsinger, Charles L. 1988-1991. Personal observations.

Daubenmire, R.F. 1968. Plant communities: a textbook of plant synecology. New York: Harper \& Row. 300 p.

Deevy, David. 1991. Personal Communication. Forester, Kootenai National Forest. Libby, Montana.

Eyre, F.H. (ed.) 1980. Forest Cover Types of the United States and Canada. Society of American Foresters. 148 p.

Fites, J. 1992. Distribution and Habitat of Pacific yew in the northern Sierra Nevada and southern Cascades of California. Unpublished. Document on file.

Hartzell Jr., Hal. 1991. The yew tree: a thousand whispers. Eugene, OR: Hulogosi.

Henderson, J.A. 1992. Paper; Distribution of Pacific yew in Mt. Baker-Snoqualmie and Olympic National Forests. Unpublished. Document on File.

USDA, 1992. Proceedings: Management Utilization and Conservation of Pacific Yew in the Blue Mountains Forum. LaGrande, Oregon. Unpublished. Document on File. 
Atzet, Tom A. 1991. Personal communications, Ecologist,USDA Forest Service, Siskiyou National Forest, Grants Pass, Oregon.

Brockway, Dale G., Christopher Topik, Miles A. Hemstrom, and William E. Emmingham. 1983. Plant associations and management guide for the Pacific silver fir zone, Gifford Pinchot National Forest. R6-Ecol-130a-1983. USDA Forest Service, Pacific Northwest Region, Portland, Oregon.

Cooper, Stephen V., Kenneth E. Neiman, Robert Steele, and David W. Roberts. 1987. Forest habitat types of northern Idaho: a second approximation. USDA Forest Service, General Technical Report INT-236. Intermountain Research Station, Ogden, Utah. 135 p.

Franklin, Jerry F., William H. Moir, Miles A. Hemstrom, Sarah E. Greene, and Bradley G. Smith. 1988. The forest communities of Mount Rainier National Park. Scientific Monograph Series No. 19, USDI, National Park Service, Washington, D.C. 194 p.

Halverson, N.M., C. Topik and R. VanVickle. 1986. Plant association and management guide for the western hemlock zone, Mt. Hood National Forest. USDA Forest Service, Pacific Northwest Region, R6 Ecol 232-1986. 111 p. illus.

Hemstrom, Miles A., William E. Emmingham, Nancy M. Halverson, and others. 1982. Plant association and management guide for the Pacific silver fir zone, Mt. Hood and Willamette National Forests. R6-Ecol-100-1982a. USDA Forest Service, Pacific Northwest Region. Portland, Oregon. $104 \mathrm{p}$.
ReferencesPlant Associations Guides 
Hemstrom, Miles A., Sheila E. Logan, and Warren Pavlat. 1985. Preliminary plant association and management guide, Willamette National Forest. USDA Forest Service, Pacific Northwest Region, Portland, OR. 206 p.

Henderson, J.A., D.A. Peters, and R.D. Lesher. 1988. Forested plant associations of the Olympic National Forest. USDA Forest Service, Pacific Northwest Region. R6 Ecol. Tech. Paper 001-88.

Johnson, Charles G. Jr. and Steven A. Simon. 1987 Plant associations of the Wallowa-Snake Province: WallowaWhitman National Forest. R6-Ecol-TP-255A-86. USDA Forest Service, Pacific Northwest Region, Wallowa-Whitman National Forest, Baker, Oregon. 399 p.

Pfister, Robert D., Bernard L. Kovalchick, Stephen F. Arno, and Richard C. Presby. 1977. Forest habitat types of Montan. USDA Forest Service, General Technical Report INT-34. Intermountain Forest and Range Experiment Station, Ogden, Utah. 174 p.

Topik, Christopher, Nancy M. Halverson, and Dale G. Brockway. 1986. Plant association guide for the western hemlock zone, Gifford Pinchot National Forest, USDA Forest Service, R6-Ecol-230a-1986. Pacific Northwest Region, Portland, OR. 132 p.

Williams, C.K. and T.R. Lillybridge. 1988. Forested plant associations of the Colville National Forest. USDA Forest Service, Pacific Northwest Region. R6 Ecol. Tech. Paper 008-88. 


\section{Appendix I \\ Soils}


Changes Made Since the Draff EIS

Appendix I

No Changes. 


\section{Appendix I}

Soils

\section{Table of Contents}

Soils

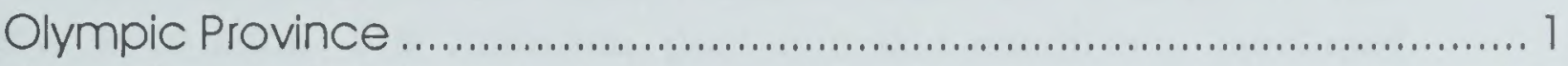

Coast Range Province .................................................................. 2

Siskiyou Province ................................................................................ 2

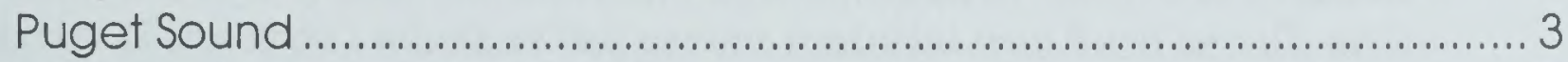

Western Cascades Province ............................................................... 3

Northwestern Cascades Province ......................................................... 3

Recent (high) Cascades Province ................................................ 4

Modoc Plateau (Upper Basin and Range Province) .............................. 5

Sierra Nevadas .............................................................................. 5

Northeastern Cascades ................................................................ 6

Okanogan Highland Province ...................................................... 6

Blue Mountains Province ........................................................... 7

Wallowa Province ............................................................................. 7

Northern Rocky Mountains Province -North Part ................................... 8

Northern Rocky Mountains Province -Central Part ................................. 9

Terminology ............................................................................................ 10

Table: Physiographic Provinces and Conditions ..................................... 11

Figure: Broad Physiographic Provinces .............................................. 12

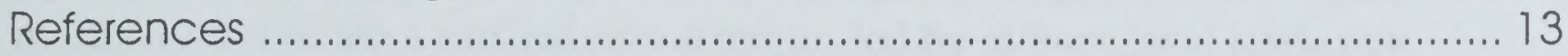



Oregon, Washington, Montana and Idaho can be divided into generalized physiographic provinces. (Fenneman, 1931; Arnold, 1974; Franklin \& Dyrness, 1973; Boyer \& Rich, Unpublished, 1978). These provinces are characterized by their geologic origin and shape as well as erosional, depositional, and mountain building processes. Understanding some of the processes that help shape the landscape provides insight into predicting human activities on the landscapes. Processes themselves are not phenomena, but are the interactions of different elements over time. For instance, past climatic conditions produced erosional forces (sculpturing) and deposition that created existing landforms. The impact of erosional forces depends upon the original geology of the area - whether the parent material was hard or soft, and so on. Biological communities, in turn, are influenced by the interaction of annual climatic patterns and existing landforms. Changes in any of these elements alter other elements through interaction. Resource management (as in Pacific yew harvest activities) produce changes in the biological community that may influence the landform and the relative impact of climate on the site.

\section{Olympic Province}

The major portion of this province exhibits extensive glaciation. Main river valleys are broad and U-shaped. Major peaks are ringed with cirques (circular spaces) and many contain active glaciers. Extremely high precipitation has caused rapid downcutting by streams and, with past glacial erosion, has created steep mountain slopes. These rugged mountains provide a central core surrounded by almost level lowlands which are a result of glacial action. The province has a very moist marine climate, one of the wettest annually in the continental United States (over 200 inches). Most precipitation occurs as rain except at higher elevations, where snow dominates. Due to the heavy snowfall, glaciers are common at the upper elevations. Heavy summer rains are also common. Two major runoff periods occur, spring and late fall. Typical vegetation includes extremely dense stands of Douglas-fir, western hemlock, and western redcedar, with Sitka spruce along the western edges (the Pacific Coastline). Soils in the Sitka spruce community are medium to coarse textured, and shallow to moderately deep. In the hemlock and subalpine zones they are medium textured, and shallow to moderately deep. 


\section{Coast Range Province}

This province contains steep mountain slopes with ridges that are often extremely sharp. The ridge system is usually parallel to the coast, but is dissected so much that this may not be readily apparent. The topography varies as well. The dunal area is nearly level with steep lands along the eastern edges. Scattered, often barren peaks rise well above surrounding ridges. The province has a moist marine climate with annual precipitation of 60 to 120 inches. Most of this occurs as rain. Late fall floods are common and summers and winters are relatively mild. One major runoff period usually occurs in late fall or early winter. Vegetation is characterized by Sitka spruce, western hemlock, western redcedar, Douglas-fir, grand fir, and red alder. Soils are medium textured and shallow to moderately deep at the lower elevations, and close to the coastal fog zone. Further inland and upslope, medium to fine textured and moderate to deep soil mantles predominate. Sandstones, basalts, and other volcanic materials are common to this province.

Yew is rare in the Coast Range between the Quinault Indian Reservation in Washington and the Umpqua River in Oregon. It is much more abundant east of Interstate 5 in the lowlands and foothills of the Cascades.

\section{Siskiyou Province}

This province is found in northern California and southern Oregon and exhibits an ancient, and now greatly dissected, uplifted plain. Some peaks, however, rise above the generally even ridge. The province has a moist marine climate with annual precipitation (mostly rain) of 45 to 90 inches. Late fall floods are common, summers are warm and dry, and winters are relatively mild. Vegetation reflects elements of the northern California coast and southern Oregon flora, with many species indigenous only to the Siskiyou character type. Major plant communities are distributed in relation to moisture and elevation and include: Pine-oak-fir, firbroad-leaved species, pine-fir-cedar-true firs, white fir, Shasta red fir, western hemlock, and Sitka spruce. This diversity combines with a long history of disturbance, primarily fire, to produce an extremely varied array of biological communities. Soils are generally medium textured and moderately deep to deep. Large areas of serpentine and peridodotite bedrock are common to this province. 


\section{Puget Sound}

This province was subjected to massive continental glaciation, which formed an area of low relief broken by sounds, low moraine ridge systems, rounded hummocks, and many included lakes. The province has a moist marine climate with annual precipitation (mostly rain) of 15 to 60 inches. Peak runoff generally occurs in late fall to early winter. Vegetation is characterized by Douglas-fir, Sitka spruce, western hemlock, western redcedar, and grand fir. Some stands of lodgepole pine are found on moraine remnants.

\section{Western Cascades Province}

This province is composed of a slightly folded and uplifted accumulation of weathered volcanic flows. The area is characterized by a general conformity in ridge crests separated by deep valleys with steep, highly dissected side slopes. In the southern portion of this province, major valleys are "V-shaped", indicating a strong watererosion process rather than glacial scouring. Glacial features are evident but not pronounced throughout the entire province. Climate is similar to the northeastern Cascades but with slightly warmer temperatures and lower annual precipitation (about 130 inches). The major runoff period is usually late fall to early winter. Vegetation is characterized by Douglas-fir, western hemlock, grand fir, and subalpine fir. Mixed conifer and subalpine zones are also found in this province. Soils in the hemlock zone are generally fine textured and deep, while in the mixed conifer zone they are medium textured and moderately deep. In the oak woodlands vegetation zone they are fine textured and moderately deep, and in the subalpine zone they are medium to coarse textured and moderately deep.

\section{Northwestern Cascades Province}

This province is characterized by sharp, jagged peaks and deep valleys resulting mostly from alpine glaciation. A striking topographic feature is the approximately uniform elevation of the main ridgetops. Towering above these relatively even crests are two dormant volcanoes (Mt. Baker and Glacier Peak) as well as several granitic peaks of exceptional height. Main stream valleys contain deep accumulations of glacial debris. This is an area of heavy annual precipitation (from 80 to 160 inches), much of which occurs as snow. The climate is noted 
for high humidity and relatively mild temperatures. Both late fall floods from rain and high summer streamflows from glacier melt are common. Vegetation is characterized by western hemlock, Douglas-fir, and western redcedar. Subalpine fir, noble fir, and Pacific silver fir occur at higher elevations. In the hemlock zone the soils are medium to coarse textured and moderately deep. In the subalpine zone they are medium textured and generally shallow.

\section{Recent (high) Cascades Province}

This province consists of a volcanic plateau capped by shield volcanoes, cinder cones, and other volcanic forms - all of which are in various stages of disintegration. It is essentially an area of gently sloping terrain, interrupted at intervals by glaciated channels in the major drainages. The area is dotted with volcanic peaks and cones rising 150 to 5000 feet above the surrounding landscape. Much of the area is mantled with pumice and volcanic ash. It is an area of climatic extremes. In Washington, annual precipitation ranges from 15 inches on the eastern edge to 140 inches at the crest of the Cascades. Summer is characterized by low humidity and little rain. The major source of streamflow is from snowmelt with peak flows occurring in late spring. In southern Oregon, annual precipitation ranges from 20 to 60 inches, of which about 50 percent occurs as snow. This area is characterized by warm summers and relatively cold winters. High rainfall intensities associated with summer thunderstorms are common throughout the province. Vegetation varies greatly in composition and includes: Douglas-fir, grand fir, subalpine fir, and western hemlock as well as ponderosa and lodgepole pine. In the hemlock and mixed conifer zones, soils are medium textured and moderately deep to deep. The subalpine zone is characterized by medium to coarse textured and generally shallow soils. In the Douglas-fir/ grand fir (non-pumice soils) zone, they are medium to coarse textured and moderately deep to deep. The Douglas-fir/grand fir (pumice soils) zone soils are typically coarse textured and deep. In the ponderosa pine/lodgepole (non-pumice) zone, soils are medium to coarse textured and moderately deep, while in the ponderosa pine/lodgepole (pumice soils) zone, they are coarse textured and moderately deep to deep. 


\section{Modoc Plateau (Upper Basin and Range Province)}

This province exhibits fault-block mountains. Most of the enclosing basins, surrounded by lifted blocks, are internally drained. These formations create predominantly horizontal profiles in mountain silhouette with occasional cone-shaped features. Annual precipitation is moderate (15 to 30 inches) and occurs mostly as snow. Most streams are perennial (flow throughout the year) and many undrained basins contain shallow lakes and marshes. High intensity precipitation from summer thunderstorms is common. Peak streamflows occur in the spring.

Vegetation is characterized by mixed conifer, ponderosa pine, lodgepole pine, and grass-shrub communities. In the Douglas-fir/grand fir (non-pumice) soils, the soil textures are generally medium to coarse and moderately deep. In the Douglas-fir/grand fir (pumice) soils, the soils are coarse textured and moderately deep to deep. The ponderosa pine/lodgepole pine (non-pumice soils) communities are typically medium to coarse textured and moderately deep, while the ponderosa pine/lodgepole (pumice soils) zones are coarse textured and moderately deep to deep.

\section{Sierra Nevadas}

This province is characterized by a block mountain range that is tilted to the west, with evenly crested ridges and alpine peaks near the east side. Deep river-cut canyons occur on the western slopes while at their upper reaches, especially in massive granites of the higher Sierras, the canyons are modified by glacial sculpturing. Glacial moraines and alluvial fans spread over fault rifts and dropped blocks along the eastern base of the range. Metamorphic bedrock (capped by volcanics) predominates the western flank and northern end of the Sierras.

Vegetation varies with elevation and also in the rain shadow on the easterly flanks of this range. On the westerly flanks, oak brush gives way to mixed conifer predominated by pine. This grades from mixed pine/oak to a true mixed conifer zone with pine and Douglas-fir. Above this elevation is an area of true fir and finally above timberline, low brush and barrens. 


\section{Northeastern Cascades}

This province exhibits glacial sculpturing which has created an area of great relief with steep-sided, very deep valleys and long finger lakes. The area is made of granitic batholiths (folded and, in part, metamorphosed) and sedimentary rock with ridgetops having approximately uniform crest elevations. An area of climatic extremes, annual precipitation ranges between 20 to 120 inches, most of which occurs as snow. Peak water flows occur in late spring and early summer. Summer temperatures are very hot. High rainfall intensities associated with summer thunderstorms are common. Vegetation is characterized by a wide range of species, including subalpine fir, grand fir, Douglas-fir, and western larch, as well as some ponderosa and lodgepole pine.

\section{Okanogan Highland Province}

This province reflects repeated continental glaciation, resulting in a generally rolling terrain of moderate slopes and broad, rounded summits. Scattered peaks rise 3,000 to 4,000 feet above the general terrain, dividing the area into several upland areas separated by a series of broad north-south valleys. Annual precipitation ranges from 20 to 45 inches. A continental-type climate prevails here with cold winters and warm summers, and high summer rainfall intensities. Peak runoff occurs in mid-spring. Vegetation is characterized by grand fir and Douglas-fir with larch and ponderosa pine. In the subalpine and the Douglas-fir/grand fir (non-pumice soils) zone and in the Ponderosa pine/lodgepole pine (non-pumice soils) zone, the soils are medium to coarse textured and moderately deep. 


\section{Blue Mountains Province}

This province is composed of several ranges of mountains separated by faulted valleys, synclinal (downfolded) basins, canyon lands, and lava plateaus. Topographic relief in the mountains is highly variable with moderately steep sideslopes common. Dissection of the lava plateaus has also created steep side slopes. Most of the area is blanketed by volcanic ash from the Mt. Mazama eruption. Climate is more typical of the continental type, with annual precipitation ranging from 15 to 60 inches, much of which occurs as snow. Peak runoff occurs in the spring. The province has relatively cold winters and warm summers with wide diurnal temperature fluctuations. Summers typically have low humidities. Vegetation is characterized by ponderosa pine, grand fir, Douglas-fir, some subalpine fir communities, and shrub-grass communities. The soils are medium textured and moderately deep to deep in the subalpine and Douglas-fir/grand fir (non-pumice soils) zones, and medium to fine textured and moderately deep in the ponderosa pine/ lodgepole pine (non-pumice soils) zone.

\section{Wallowa Province}

This province consists of a mountainous "island" surrounded by lava plateaus. These mountains are part of the Blue Mountain Province but are distinctive, since alpine glaciation has created a very precipitous and ruggedly mountainous area; relief is much greater than in the Blue Mountains type. Climate is similar to the Blue Mountains Province except that the Wallowas have higher annual precipitation, ranging from 25 to 80 inches (primarily caused by the higher elevations). Rainfall intensities are greater and temperatures are colder than in the Blue Mountain Province. Peak runoff occurs in late spring or early summer. Vegetation is characterized by grand fir, Douglas-fir, subalpine fir, mountain hemlock, and ponderosa pine. In the Douglas-fir/ grand fir (non-pumice soils) plant community, soils are medium textured and moderately deep. Climatic conditions in this area are characterized by warm, dry summers and cool, wet winters, with snow pack providing the major source of water after the early spring peak flow. Isolated thunderstorms are not uncommon during frontal passage in the summer months.

Soils grade from deep and well-developed to shallow, poorly developed granitic material at high elevations. 


\section{Northern Rocky Mountains Province - North Part}

This province is found in northern Idaho and western Montana and is comprised of a number of mountain ranges. Most elevations are between 2000-9000 feet. The continental ice sheet extended into the northern part of the area and produced rounded and smooth topographic features. Glacial till, outwash, and lacustrine material can be found on the landscapes affected by glaciation. Alpine glaciers occurred at higher elevations throughout the province producing cirque basins on north and east aspects. South of the area affected by continental glaciation, the landscapes are largely residual with the regolith having formed by in-place weathering. These residual landscapes vary from being non-dissected to highly dissected and from weakly to highly weathered.

The major parent materials for the soils in this geomorphic unit include:

1. Belt Subgroup - located mainly east and southeast of Coeur d'Alene Lake to the Montana border and east of Pend Oreille Lake along the Montana border to the Canadian border. Rocks and weathered materials from rocks consist of gneisses, schists, amphibolites, and quartzites; shales and sandstones; some gabbro and diorite; and local silicic intrusives.

2. Glacial features - located mainly in the area from Coeur d'Alene Lake north to the Canadian border.

3. Columbia River Group - located mainly in the Coeur d'Alene Lake and Orofino areas.

4. Other minor formations such as metamorphic complexes, quartzites, shale, limestone, and conglomerates.

Volcanic ash from Mt. Mazama is found at the soil surface. The ash is thinner in the northern and eastern parts of the province. The climate is influenced by Pacific maritime air masses. Winters are cool and wet while summers are dry. Rain-on-snow events occur at mid to lower elevations during the winter on the western slopes only. Precipitation varies from about 15 inches at lower elevations to around 100 inches at 
the highest elevations. Vegetation at higher elevations is mainly subalpine fir and Englemann spruce with some mountain hemlock. Midelevation sites commonly have western white pine, western redcedar, western larch, grand fir, and lodgepole pine. Western hemlock is important in the northwestern portion of the province. Douglas-fir and ponderosa pine occur at lower elevations and on dry aspects. Dry bunchgrass can be found in lower elevation river canyons in the southern part of the province. Most soils have a medium textured volcanic ash surface layer. The soils associated with granitics have coarse textured subsoils and substratums. Those associated with "Belt" rocks have medium textured or moderately coarse textured subsoils and substratums. The soils derived from glacial till frequently have very dense subsoils and substratums.

\section{Northern Rocky Mountains Province - Central Part}

This province is characterized by high mature mountains and deep intermontane valleys. About 10 percent of the landscape has been altered by alpine glaciation. Steep stream breaklands and colluvial slopes are almost 50 percent of the landscape. Broadly rounded ridges affected by periglacial activity are 17 percent, and dissected hills and rolling uplands are 28 percent.

The major parent materials for soils in this geomorphic unit include:

1. Idaho Batholith and related rocks - dominant formation found throughout the central part of the province.

2. Gneisses, schists, and quartzites; andesites and basalts.

Elevations range from 1000 to $8000+$ feet, with a climate that is markedly different from the sections to the north. Mountain barriers impede the normal movement of moisture-laden air masses from the Pacific Ocean.

Soils in a large portion of the area are dominantly deep to moderately deep, with loamy sands to sandy loam textures. The influence of Aeolian (windborne) material tends to be masked by glacial, frost churning, and colluvial action. Ash deposits about one foot thick over well-weathered bedrock can be found in the Red River Basin subsection. 
Habitat types are dominantly subalpine fir/beargrass, subalpine fir/whortleberry, with whitebark pine/subalpine fir on high knobs and rocky ridges. Douglas fir/beargrass is on lower elevation north slopes with Douglas fir/ninebark and Douglas fir/Agsp on south slopes.

\section{Terminology}

Soil mantle effective depths (rooting zone) are represented by three classifications: shallow, less than 20 inches; moderate, 20 to 40 inches; and deep, 40 inches or more. Three classes are also included for soil textures:

Coarse - sands, sandy loams, loamy sands and gravelly to stony combinations;

Medium - loams, silt loams, and clay loams; and

Fine - clays, silty clays, and silty clay loams (ColumbiaNorth Pacific Regional Comprehensive Framework and Study, 1970). 


\begin{tabular}{|c|c|c|c|c|c|c|c|}
\hline \multicolumn{8}{|c|}{ Physiographic Provinces and Conditions } \\
\hline Province & $\begin{array}{l}\text { Vegetation } \\
\text { Zone }\end{array}$ & $\begin{array}{c}\text { Soil } \\
\text { Depth }\end{array}$ & $\begin{array}{l}\text { Character } \\
\text { Texture }\end{array}$ & $\begin{array}{l}\text { Vegetation } \\
\text { Recovery } \\
\text { Rate }\end{array}$ & $\begin{array}{l}\text { Elevation } \\
\text { Range } \mathrm{Ft} \text {. }\end{array}$ & $\begin{array}{l}\text { Average } 1 \\
\text { PPT. IN. }\end{array}$ & $\begin{array}{l}\text { Runoff } \\
\text { Inches }\end{array}$ \\
\hline Olympic & $\begin{array}{l}\text {--Sitka Spruce } \\
\text {--Hemlock } \\
\text {--Subalpine }\end{array}$ & $\begin{array}{l}\text { Shall-Moderate } \\
\text { Shall-Moderate } \\
\text { Shall-Medium }\end{array}$ & $\begin{array}{l}\text { Med-Coarse } \\
\text { Medium } \\
\text { Medium }\end{array}$ & $\begin{array}{l}\text { Rapid } \\
\text { Rapid } \\
\text { Mod-Rapid }\end{array}$ & $\begin{array}{l}0-500 \\
0-3,280 \\
2,000-7,000\end{array}$ & $\begin{array}{l}80-120 \\
60-120 \\
120+\end{array}$ & $\begin{array}{l}95-105 \\
80-100 \\
-100\end{array}$ \\
\hline Coast Range & $\begin{array}{l}\text {--Sitka Spruce } \\
\text {--Hemlock }\end{array}$ & $\begin{array}{l}\text { Shall-Moderate } \\
\text { Moderate-Deep }\end{array}$ & $\begin{array}{l}\text { Medium } \\
\text { Med-Fine }\end{array}$ & $\begin{array}{l}\text { Rapid } \\
\text { Rapid }\end{array}$ & $\begin{array}{l}0-500 \\
0-3,200\end{array}$ & $\begin{array}{l}80-120 \\
60-120\end{array}$ & $\begin{array}{l}60-70 \\
40-100\end{array}$ \\
\hline Siskiyou & $\begin{array}{l}\text {--Mixed Conifer } \\
\text {--Mixed Evergreen }\end{array}$ & $\begin{array}{l}\text { Mod-Deep } \\
\text { Moderate }\end{array}$ & $\begin{array}{l}\text { Medium } \\
\text { Med-Fine }\end{array}$ & $\begin{array}{l}\text { Mod-Rapid } \\
\text { Mod-Rapid }\end{array}$ & $\begin{array}{l}2,500-4,600 \\
2,600-4,550\end{array}$ & $\begin{array}{l}35-90 \\
30-60\end{array}$ & $\begin{array}{l}20-50 \\
20-40\end{array}$ \\
\hline Puget Sound & --Hemlock & Shallow & Med-Coarse & Rapid & $0-3,300$ & $15-60$ & $5-30$ \\
\hline $\begin{array}{l}\text { Western } \\
\text { Cascades }\end{array}$ & $\begin{array}{l}\text {--Hemlock } \\
\text {--Mixed Conifer } \\
\text {--Subalpine }\end{array}$ & $\begin{array}{l}\text { Deep } \\
\text { Moderate } \\
\text { Moderate }\end{array}$ & $\begin{array}{l}\text { Fine } \\
\text { Medium } \\
\text { Med-Coarse }\end{array}$ & $\begin{array}{l}\text { Rapid } \\
\text { Rapid } \\
\text { Mod-Rapid }\end{array}$ & $\begin{array}{l}0-3,200 \\
2,500-4,600 \\
2,000-7,200\end{array}$ & $\begin{array}{l}60-120 \\
35-50 \\
130+/-\end{array}$ & $\begin{array}{l}40-70 \\
20-40 \\
60-100\end{array}$ \\
\hline $\begin{array}{l}\text { North Western } \\
\text { Cascades }\end{array}$ & $\begin{array}{l}\text {--Hemlock } \\
\text {--Subalpine }\end{array}$ & $\begin{array}{l}\text { Moderate } \\
\text { Shallow }\end{array}$ & $\begin{array}{l}\text { Med-Coarse } \\
\text { Medium }\end{array}$ & $\begin{array}{l}\text { Mod-Rapid } \\
\text { Mod-Rapid }\end{array}$ & $\begin{array}{l}0-3,300 \\
2,000-7,200\end{array}$ & $\begin{array}{l}60-120 \\
160+/-\end{array}$ & $\begin{array}{l}60-90 \\
80-100\end{array}$ \\
\hline $\begin{array}{l}\text { Recent High } \\
\text { Cascades }\end{array}$ & $\begin{array}{l}\text {--Hemlock } \\
\text {--Mixed Conifer } \\
\text {--Subalpine } \\
\text {--D.F/Gr.F.Non-Pum } \\
\text {--D.F/Gr.F.Pumice } \\
\text {--P.P./L.P.Non-Pum } \\
\text {--P.P./L.P.Pumice }\end{array}$ & $\begin{array}{l}\text { Mod-Deep } \\
\text { Mod-Deep } \\
\text { Shallow } \\
\text { Mod-Deep } \\
\text { Deep } \\
\text { Moderate } \\
\text { Mod-Deep }\end{array}$ & $\begin{array}{l}\text { Medium } \\
\text { Medium } \\
\text { Med-Coarse } \\
\text { Med-Coarse } \\
\text { Coarse } \\
\text { Med-Coarse } \\
\text { Coarse }\end{array}$ & $\begin{array}{l}\text { Mod-Rapid } \\
\text { Slow } \\
\text { Slow } \\
\text { Moderate } \\
\text { Moderate } \\
\text { Slow } \\
\text { Slow }\end{array}$ & $\begin{array}{l}\text { N.D. } \\
2,500-4,600 \\
2,000-7,200 \\
\text { N.D. } \\
\text { N.D. } \\
\text { N.D. } \\
\text { N.D. }\end{array}$ & $\begin{array}{l}60-120 \\
30-60 \\
\text { N.D. } \\
\text { N.D. } \\
14-30+ \\
14-30 \\
14-30\end{array}$ & $\begin{array}{l}40-70 \\
20-40 \\
30-70 \\
20-30 \\
10-20 \\
5-10 \\
2-10\end{array}$ \\
\hline Modoc Plateau & $\begin{array}{l}\text {--D.F/Gr.F.Non-Pum } \\
\text {--D.F/Gr.F.Pumice } \\
\text {--P.P./L.P.Non-Pum } \\
\text {--P.P./L.P.Pumice }\end{array}$ & $\begin{array}{l}\text { Moderate } \\
\text { Mod-Deep } \\
\text { Moderate } \\
\text { Mod-Deep }\end{array}$ & $\begin{array}{l}\text { Med-Coarse } \\
\text { Coarse } \\
\text { Med-Coarse } \\
\text { Coarse }\end{array}$ & $\begin{array}{l}\text { Mod-Rapid } \\
\text { Moderate } \\
\text { Slow } \\
\text { Slow }\end{array}$ & $\begin{array}{l}\text { N.D. } \\
\text { N.D. } \\
\text { N.D. } \\
\text { N.D. }\end{array}$ & $\begin{array}{l}\text { N.D. } \\
\text { N.D. } \\
14-30 \\
14-30\end{array}$ & $\begin{array}{l}\text { N.D. } \\
\text { N.D. } \\
\text { N.D. } \\
\text { N.D. }\end{array}$ \\
\hline $\begin{array}{l}\text { Sierra } \\
\text { Nevadas }\end{array}$ & $\begin{array}{l}\text {--True Fir } \\
\text {--Mixed Conifer } \\
\text {--Ponderosa Pine }\end{array}$ & $\begin{array}{l}\text { Shallow } \\
\text { Mod-Deep } \\
\text { Deep }\end{array}$ & $\begin{array}{l}\text { Coarse } \\
\text { Med-Coarse } \\
\text { Medium }\end{array}$ & $\begin{array}{l}\text { Mod-Slow } \\
\text { Moderate } \\
\text { Slow }\end{array}$ & $\begin{array}{l}6,000+ \\
4,000-7,000 \\
500-3,500+\end{array}$ & $\begin{array}{l}70+ \\
40-60 \\
30-50\end{array}$ & $\begin{array}{l}\text { N.D. } \\
\text { N.D. } \\
\text { N.D. }\end{array}$ \\
\hline $\begin{array}{l}\text { North Eastern } \\
\text { Cascades }\end{array}$ & $\begin{array}{l}\text {--Subalpine } \\
\text {--D.F/Gr.F.Non-Pum } \\
\text {--D.F/Gr.F.Pumice } \\
\text {--P.P./L.P.Non-Pum } \\
\text {--P.P./L.P.Pumice }\end{array}$ & $\begin{array}{l}\text { Moderate } \\
\text { Moderate } \\
\text { Mod-Deep } \\
\text { Moderate } \\
\text { Mod-Deep }\end{array}$ & $\begin{array}{l}\text { Coarse } \\
\text { Med-Coarse } \\
\text { Coarse } \\
\text { Med-Coarse } \\
\text { Coarse }\end{array}$ & $\begin{array}{l}\text { Mod-Slow } \\
\text { Mod-Rapid } \\
\text { Moderate } \\
\text { Slow } \\
\text { Slow }\end{array}$ & $\begin{array}{l}\text { 2,000-7,200 } \\
\text { N.D. } \\
\text { N.D. } \\
\text { N.D. } \\
\text { N.D. }\end{array}$ & $\begin{array}{l}120+ \\
\text { N.D. } \\
14-30 \\
14-30 \\
14-30\end{array}$ & $\begin{array}{l}40-70 \\
10-40 \\
10-40 \\
5-10 \\
5-10\end{array}$ \\
\hline $\begin{array}{l}\text { Okanogan } \\
\text { Highland }\end{array}$ & $\begin{array}{l}\text {--Subalpine } \\
\text {--D.F/Gr.F.Non-Pum } \\
\text {--P.P./L.P.Non-Pum }\end{array}$ & $\begin{array}{l}\text { Moderate } \\
\text { Moderate } \\
\text { Moderate }\end{array}$ & $\begin{array}{l}\text { Med-Coarse } \\
\text { Med-Coarse } \\
\text { Med-Coarse }\end{array}$ & $\begin{array}{l}\text { Slow } \\
\text { Moderate } \\
\text { Slow-Mod }\end{array}$ & $\begin{array}{l}2,000-7,200 \\
\text { N.D. } \\
\text { N.D. }\end{array}$ & $\begin{array}{l}\text { N.D. } \\
\text { N.D. } \\
14-30\end{array}$ & $\begin{array}{l}20-40 \\
10-20 \\
1-10\end{array}$ \\
\hline $\begin{array}{l}\text { Blue } \\
\text { Mountain }\end{array}$ & $\begin{array}{l}\text {--Subalpine } \\
\text {--D.F/Gr.F.Non-Pum } \\
\text {--P.P./L.P.Non-Pum }\end{array}$ & $\begin{array}{l}\text { Moderate } \\
\text { Mod-Deep } \\
\text { Moderate }\end{array}$ & $\begin{array}{l}\text { Medium } \\
\text { Medium } \\
\text { Med-Fine }\end{array}$ & $\begin{array}{l}\text { Mod-Slow } \\
\text { Moderate } \\
\text { Slow }\end{array}$ & $\begin{array}{l}2,000-7,200 \\
\text { N.D. } \\
\text { N.D. }\end{array}$ & $\begin{array}{l}40-60 \\
30-50 \\
14-30\end{array}$ & $\begin{array}{l}20-40 \\
10-20 \\
2-10\end{array}$ \\
\hline Wallowas & --D.F/Gr.F.Non-Pum & Moderate & Medium & Moderate & N.D. & $25-80$ & N.D. \\
\hline $\begin{array}{l}\text { Rocky Mtns. } \\
\text { North }\end{array}$ & $\begin{array}{l}\text {--Subalpine } \\
\text {--D.F/Gr.F.Non-Pum } \\
\text {--WRC/Hem }\end{array}$ & $\begin{array}{l}\text { Mod-Deep } \\
\text { Mod.Deep-Deep } \\
\text { Mod.Deep-Deep }\end{array}$ & $\begin{array}{l}\text { Coarse } \\
\text { Med-Coarse } \\
\text { Med-Coarse }\end{array}$ & $\begin{array}{l}\text { Mod-Slow } \\
\text { Rapid } \\
\text { Rapid }\end{array}$ & $\begin{array}{l}5,000-7,000 \\
3,000-6,000 \\
2,000-4,000\end{array}$ & $\begin{array}{l}60+ \\
35-60 \\
30-40\end{array}$ & $\begin{array}{l}30-50 \\
15-30 \\
10-25\end{array}$ \\
\hline $\begin{array}{l}\text { Rocky Mtns. } \\
\text { Central }\end{array}$ & $\begin{array}{l}\text {--Subalpine } \\
\text {--D.F/Gr.F.Non-Pum } \\
\text {--WRC/Hem } \\
\text {--Ponderosa Pine }\end{array}$ & $\begin{array}{l}\text { Shallow } \\
\text { Mod-Deep } \\
\text { Mod-Deep } \\
\text { Mod-Deep }\end{array}$ & $\begin{array}{l}\text { Coarse } \\
\text { Med-Coarse } \\
\text { Coarse } \\
\text { Med-Coarse }\end{array}$ & $\begin{array}{l}\text { Slow } \\
\text { Rapid } \\
\text { Mod-Rapid } \\
\text { Rapid }\end{array}$ & $\begin{array}{l}5,500-7,500 \\
3,000-6,000 \\
3,000-5,000 \\
2,000-4,000\end{array}$ & $\begin{array}{l}40-60+ \\
35-45 \\
20-45 \\
20-30\end{array}$ & $\begin{array}{l}15-35 \\
15-30 \\
20-30 \\
15-20\end{array}$ \\
\hline
\end{tabular}




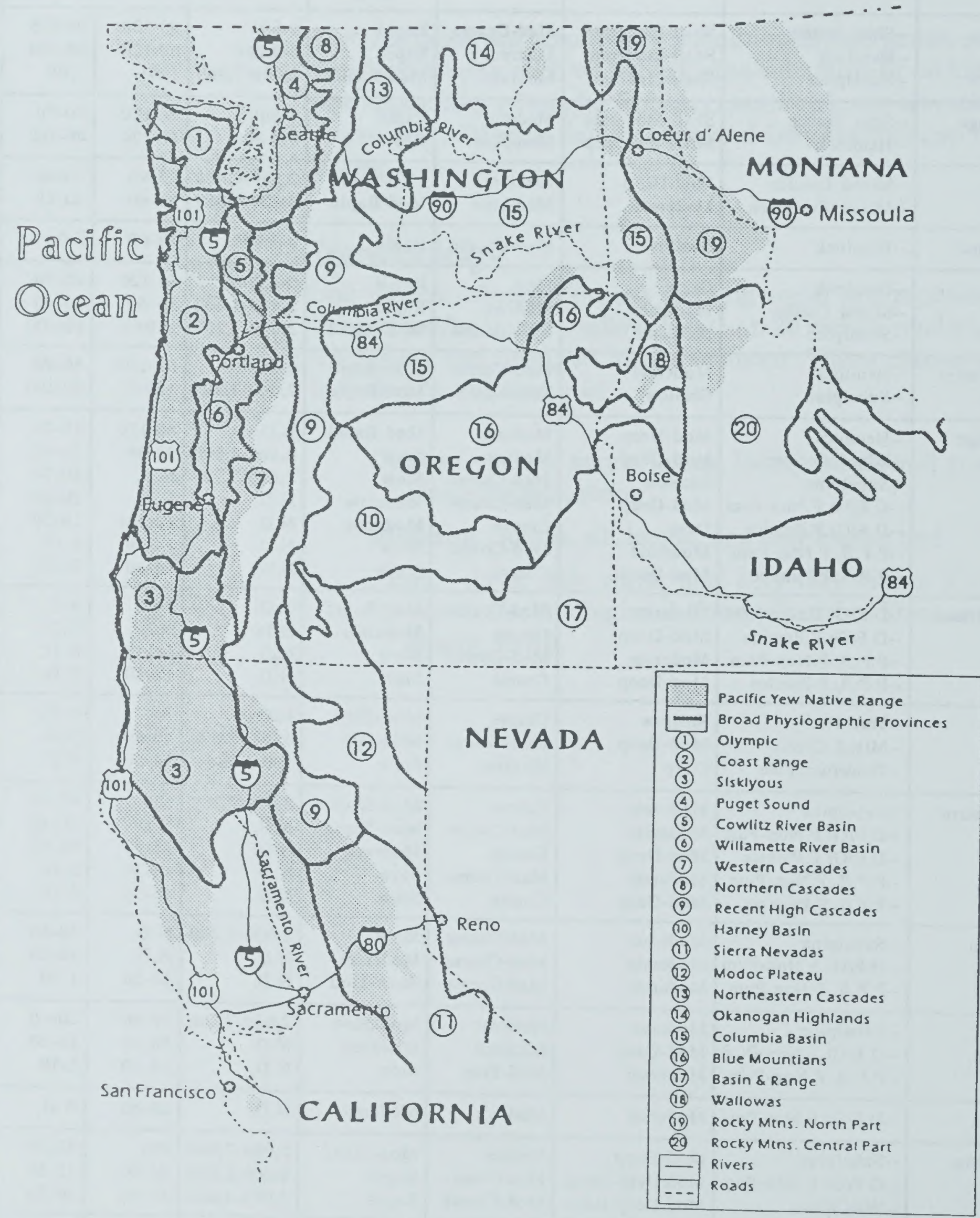




\section{References:}

Arnold, John F. 1974. Lands Systems of the Idaho Batholith.

Boyer, D.E.; Rich, L.W. 1978. Unpubl. Geomorphic Map of R-6 on Earthsat Imagery.

Columbia-North Pacific Technical Staff. 1970. ColumbiaNorth Pacific Region Comprehensive Framework Study. Water Resources, Pac. N.W. River Basin Commission. Vol. 1, App.V: 541.

Franklin, J.F.; Dyrness, C.T. 1973. Natural Vegetation in Oregon and Washington. Pacific NW Forest and Range Experiment Station Research, Paper \#80, USDA, Forest Service General Technical Report PNW-8. 417 pp.

Fenneman, Nevin M. 1931. Physiography of Western United States. New York \& London: McGraw-Hill Book Co., Inc.

USDA, Forest Service. 1992. "An Interim Guide To The Conservation And Management Of Pacific Yew." USDA, Forest Service, Pacific Northwest Region, Portland, OR. March. 



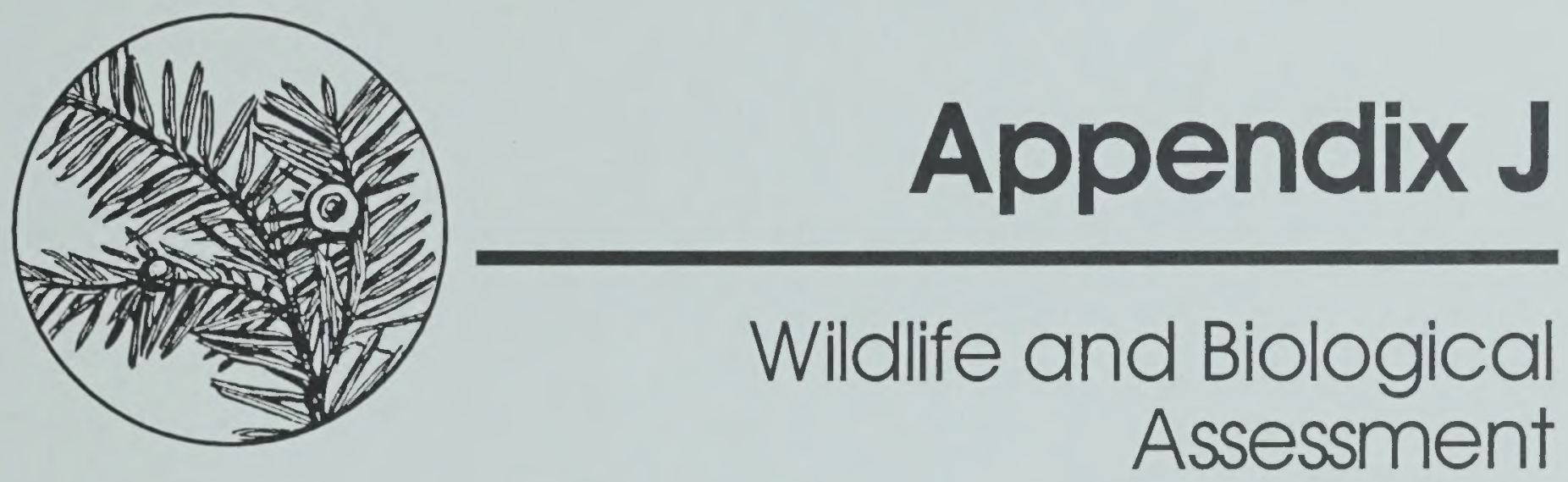




\section{Changes Made Since the Draft EIS}

\section{Appendix J}

Shifted several species between the categories (Threatened, Endangered, or Proposed), added, and dropped some according to the most current information under List $\mathrm{A}$.

Added two mammal species under "Other Common and Scientific Names Used in the Wildlife Sections."

Added "Disturbance" effects for species associated with Late Successional Forests under "Environmental Consequences for Animals and Plants.

Added a copy of the Biological Assessment and related letters. 


\section{Appendix J}

\section{Wildlife and Biological Assessment}

\section{Table of Contents}

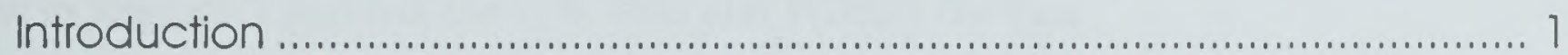

List A - Threatened, Endangered, and Proposed Wildlife .................... I

List B - Descriptions of Wildlife from List A ............................................. 3

List $C$ - Other species of concern .................................................... 10

Other Common and Scientific Names Used in the Wildlife Sections......... 15

Environmental Consequences for Animals and Plants ............................ 16

Species Associated With Late-Successional Forests ............................. 16

Alternatives and the Northern Spotted OWl ...................................... 21

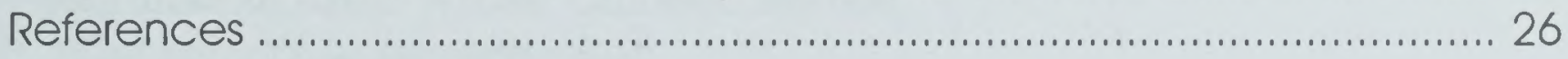

Biological Assessment

Cover Letter to U.S. Fish and Wildlife Service ....................................... 33

Cover Letter to National Marine Fisheries Service ................................. 34

Biological Assessment .............................................................................. 35

Letter of Clarification to U.S. Fish and Wildlife Service .......................... 58

Letter of Clarification to National Marine Fisheries Service ....................6 60

Letter of Concurrence from U.S. Fish and Wildlife Service .....................66 62

Letter of Concurrence from National Marine Fisheries Service ............. 64 

This appendix lists three types of wildlife: listed and proposed endangered and threatened species; proposed endangered and threatened species that may be affected by yew harvest; and other species of concern that may occur in yew habitat. Following these is an appended section with additional detail and background information on how yew harvest and the proposed alternatives could affect animals and special status plants, including the northern spotted owl.

The following are listed and proposed endangered and threatened species that may occur in the area of the proposed harvesting of Pacific yew in Regions 1 and 6 of the U.S. Fish and Wildlife Service.

Fish

Lahontan Cutthroat Trout (Oncorhynchus clarki henshawi) Paiute Cutthroat Trout (Oncorhynchus clarki seleniris)

Foskett Speckled Dace (Rhinichthys osculus ssp.)

Warner Sucker (Castostomus warnerensis) \{critical habitat\}

Sacramento River Winter Chinook Salmon

(Onchorynchus tshawytscha)

Snake River Fall Chinook Salmon

(Onchorynchus tshawytscha)

Snake River Spring/Summer Chinook Salmon

(Onchorynchus tshawytscha)

Birds

Northern Spotted Owl

(Strix occidentalis caurina) \{critical habitat\}

Aleutian Canada Goose (Branta canadensis leucopareia)

Bald Eagle (Haliaeetus leucocephalus) \{Oregon and Washington\}

Western Snowy Plover (Charadrius alexandrinus nivosus)

\section{Mammals}

Grizzly Bear (Ursus arctos)

Invertebrates

Oregon Silverspot Butterfly (Speyeria zerene hippolyta)

Valley Elderberry Longhorn Beetle

(Desmocerus californicus dimorphus)

\section{Plants}

Nelson's Checkermallow (Sidalcea nelsoniana)

\section{Introduction}

\section{List A}

Threatened 


\section{Endangered Fish}

Shortnose Sucker (Chasmistes brevirostris)

Lost River Sucker (Deltistes luxatus)

Borax Lake Chub (Gila boraxobius) \{critical habitat\}

Snake River Sockeye Salmon (Onchorynchus nerka)

Birds

Bald Eagle (Haliaeetus leucocephalus)

\{California, Idaho, Montana\}

American Peregrine Falcon (Falco peregrinus anatum)

California Brown Pelican (Pelecanus occidentalis californicus)

Marbled Murrelet (Brachyramphus marmoratus)

Peregrine Falcon (Falco peregrinus spp)

Mammals

Columbian White-tailed Deer

(Odocoileus virginianus leucurus)

Gray Wolf (Canis lupus)

Woodland Caribou (Rangifer tarandus caribou)

Plants

McDonald's Rock-cress (Arabis mcdonaldiana)

Bradshaw's Lomatium (Lomatium bradshawii)

MacFarlane's Four o'clock (Mirabilis macfarlanei)

Malheur Wire-lettuce (Stephanomeria malheurensis)

Proposed Species Fish

Oregon Chub (Oregonichthys (-Hybopsis) crameri) Plants

Applegate's Milk-vetch (Astragalus applegatei)

Marsh Sandwort (Aranaria paludicola)

List B The following species (taken from the above list) may occur in yew habitat and/or may be affected by the harvest of Pacific yew. The effects of yew harvest on these species are analyzed in Chapter IV of this EIS. Species not listed below do not occur in yew habitat, nor will they be affected by yew harvest and are therefore not analyzed in this document. 
The Chinook salmon is found along the Pacific coast from the Ventura River in southern California to Point Hope, Alaska. It is also found in northeast Asia, from the Anadyr River to Hokkaido, Japan.

Juvenile Chinook salmon spend about a year in fresh water before smolting and migrating to the Pacific Ocean. Feeding fish remain in the ocean from 3 to 4 years (range, two to eight years) before they mature and return to their parent stream to spawn. Average egg production by a female is 5,000 (range 2,250-7,750). The eggs hatch in about two months, depending on water temperature. The young remain in the gravel two to three weeks after hatching. Juveniles remain in fresh water from a few days to three years.

It is unknown at this time if this species occurs in yew habitat. As more information comes in, this question will be answered.

\section{Snake River Fall Chinook Salmon}

The Chinook salmon is found along the Pacific coast from the Ventura River in southern California to Point Hope, Alaska. It is also found in northeast Asia, from the Anadyr River south to Hokkaido, Japan.

Juvenile Chinook salmon spend about a year in fresh water before smolting and migrating to the Pacific Ocean. Feeding fish remain in the ocean from three to four years (range, two to eight years) before they mature and return to their parent stream to spawn. Fall Chinook migrate in August and September and spawn as soon as the spawning grounds are reached, when water temperatures are between $42^{\circ}$ and $58^{\circ} \mathrm{F}$. Average egg production by a female is 5,000 (range 2,250-7,750). The eggs hatch in about two months, depending on water temperature. The young remain in the gravel two to three weeks after hatching. Juveniles remain in fresh water from a few days to three years. Usually, juvenile fall Chinook feed for a short time and then migrate to the ocean.

This species may be affected by yew harvest. 


\section{Snake River Spring/Summer Chinook Salmon}

The Chinook salmon is found along the Pacific coast from the Ventura River in southern California to Point Hope, Alaska. It is also found in northeast Asia, from the Anadyr River south to Hokkaido, Japan.

Juvenile Chinook salmon spend about a year in fresh water before smolting and migrating to the Pacific Ocean. Feeding fish remain in the ocean from three to four years (range, two to eight years) before they mature and return to their parent stream to spawn. The principal spawning months are July through September. Average egg production by a female is 5,000 (range 2,2507,750 ). The eggs hatch in about two months, depending on water temperature. The young remain in the gravel two to three weeks after hatching. Juveniles remain in fresh water from a few days to three years. Most juvenile spring Chinook remain in the stream for one year before migrating.

This species may be affected by yew harvest.

\section{Northern Bald Eagle}

This eagle is listed as a threatened species in Oregon and Washington. Eagles usually locate nests in the upper canopy of large old growth trees, usually within two or three miles of coastal, lake, or river areas (Stalmaster et al., 1985). Night roosts are generally found in coniferous stands with well-developed canopies.

During winter months, bald eagles forage on water courses that support spawning salmon and/or waterfowl. The eagles generally perch in large deciduous and coniferous trees in close proximity to 
feeding areas. Eagles may gather at dusk, collecting in the open branches of large trees. From there they fly to communal night roosts, which are usually located within a few miles of feeding areas.

Bald eagle habitat on the Pacific coast is protected and managed in accordance with "The Pacific Bald Eagle Recovery Plan" (USDI Fish and Wildlife Service, 1986), and the "Working Implementation Plan for Bald Eagle Recovery in Oregon and Washington" (Washington Department of Wildlife, 1989).

This species may roost, nest, and forage in yew habitat.

\section{Northern Spotted Owl}

For more than a decade there has been growing concern and controversy about managing forest lands for the protection of the northern spotted owl. Concern and controversy increased with the June 26, 1990 listing of the northern spotted owl as threatened with extinction under the Endangered Species Act of 1973. Extensive popular and scientific literature is available which discusses various aspects of the controversy.

For a complete discussion of the habitat needs and life history of the northern spotted owl, see:

- "Report of the Advisory Panel on theSpotted Owl" (Dawson et al., 1986);

- "Final Supplement to the Environmental Impact Statement for and Amendment to the Pacific Northwest Regional Guide" (USDA, Forest Service. 1988b);

- The Interagency Scientific Committee's (ISC) "Conservation Strategy for the Northern Spotted Owl” (Thomas et al., 1990);

- The U.S. Fish and Wildlife Service's three status reviews (USDI, 1987; USDI, 1989; Anderson et al., 1990); and

- The June 26, 1990 final ruling that listed the northern spotted owl as a threatened subspecies (Federal Register, 55:26114).

This species forages, roosts, and nests in yew habitat. 


\section{Grizzly Bear}

As omnivorous, opportunistic feeders, grizzly bears use a variety of habitats. Ninety percent of the grizzly bears' diet is vegetation. Areas used by bears in the spring contain early emergent vegetation. Examples of spring bear range include south-facing avalanche chutes and shrub fields. Big game winter range and anadromous fisheries provide concentrated protein sources for bears in the spring and early summer. Summer and fall habitat components are generally composed of grass/forb and shrub communities. Examples of these include avalanche chutes, harvested units, sidehill parks, and open canopy forest. Winter den habitat is often above 6,000 feet in areas of heavy snowpack. Good denning sites may occur near ridges and upper avalanche chutes. Home ranges as large as 1,004 square miles have been reported (National Wildlife Federation, 1987; Almack, personal communication).

This species may forage in yew habitat.

\section{Endangered Species}

\section{Snake River Sockeye Salmon}

Sockeye salmon are native to the Snake River and historically were abundant in several lake systems in Idaho and Oregon. In this century, a variety of factors have led to the demise of all Snake River sockeye salmon except those returning to Redfish Lake in the Stanley Basin of Idaho.

Most of the spawning at Redfish lake is along the lake shore where ground water percolates through the gravel. A single sockeye female may contain as many as 4,000 eggs. The eggs hatch in six to nine weeks, depending on water temperature. The young remain in the gravel for another two to three weeks. During their fresh water life, juvenile sockeye salmon feed largely on zooplankton. The downstream migration of smolts occurs in the spring. The young remain at sea for two to four years before returning as adults.

This species may be affected by the harvest of yew. 


\section{Northern Bald Eagle}

This eagle is listed as endangered in California, Idaho, and Montana. Eagles usually locate nests in the upper canopy of large old growth trees, usually within two or three miles of coastal, lake, or river areas (Stalmaster et al., 1985). Night roosts are generally found in coniferous stands with well-developed canopies.

During winter months, bald eagles forage on water courses that support spawning salmon and/or waterfowl. The eagles generally perch in large deciduous and coniferous trees in close proximity to feeding areas. Eagles may gather at dusk, collecting in the open branches of large trees. From there they fly to communal night roasts, which are usually located within a few miles of feeding areas.

This species may roost, nest, and forage in yew habitat.

\section{Peregrine Falcons}

Peregrines are limited to areas which contain suitable nestingledges. Cliffs and bluffs typically found along river courses and other large bodies of water usually provide habitat for nesting peregrines (Call, 1978). Falcons prefer to nest where the concentration of prey, generally smaller birds, is high and where habitat "structural characteristics...may increase prey vulnerability” (Skaggs et al., 1986).

Peregrine habitat on the Pacific coast is managed in accordance with the "Recovery Plan for American Peregrine Falcon" (USDI Fish and Wildlife Service, 1982) and standards and guidelines in the various forest plans.

This species may use yew habitat for foraging and nesting.

\section{Marbled Murrelet}

The marbled murrelet, a member of the alcid family, is a robinsized seabird that congregates to feed primarily in salt water. Murrelets typically feed on small fish and invertebrates within one mile of shore (Marshall, 1988). They are found throughout 
the North Pacific; the American subspecies is found from Alaska in the summer to wintering grounds as far south as California.

Although marbled murrelets are numbered in the hundreds of thousands in Alaska (Marshall, 1988), and up to 3,000 off the coast of Washington (Spiech et al., in press), the numbers dwindle to approximately 1,000 breeding pairs off the coast of Oregon (Nelson et al., in press), and an estimated 1,650 birds in California (Carter and Erickson, 1988).

Marbled murrelet nests have been found from southeastern Alaska to northern California in a range of forest structures from stands of wholly old growth trees to mixed stands containing mature and old growth trees. Nest sites, characterized by depressions in moss and lichens, have been located on large, lateral branches. Murrelets have been detected as far inland as 43 miles in Washington, 35 miles in Oregon, and 24 miles in California (Nelson, 1990; Paton and Ralph, 1988).

This species may nest in yew habitat.

\section{Columbian White-tailed Deer}

This subspecies of white-tailed deer lives in Oregon and Washington, along the Columbia River from Portland to Astoria. It is also found in the Umpqua Valley near Roseburg, Oregon.

\section{Gray Wolf}

Gray wolves utilize many habitat types. The availability of prey seems to be the primary factor in determining suitability of habitat. Primary foods for wolves are ungulate species, such as deer, but wolves also consume small mammals such as rodents. There have been reports of home ranges as large as 1,197 square miles (Paradiso and Nowak, 1982).

This species may forage and den in yew habitat. 


\section{Woodland Caribou}

The woodland caribou of North America (Rangifer tarandus caribou) is broken down into two "ecotypes": mountain and northern. These ecotypes are based on the different habitat and behavior patterns of the subspecies. Only the Selkirk population of the mountain caribou is listed under the ESA, and exists in extreme northeastern Washington and northern Idaho, within the Selkirk mountains. This population is shared with British Columbia. Woodland caribou are medium sized members of the deer family (Cervidae), and can be distinguished from other members of the deer family by their large hooves, broad muzzles, and distinctive antlers (both sexes).

Caribou habitat requirements appear to be distinctive, with late winter habitats almost exclusively in the upper subalpine fir timber types with deep snows in excess of 20 feet. Here their diet consists of arboreal lichens of the genus Alectoria and Bryoria (USDI, Selkirk Mountain Recovery Plan, 1985). Spring brings an elevational shift to lower elevation open areas where early greenup of forbs and grasses is the primary diet. As summer approaches the higher elevation, moist Engelmann spruce basins are preferred, and utilized through late summer and rut. Early winter snows move the Selkirk mountain caribou to the lower elevation cedar/ hemlock old growth types and the ecotone between the cedar/ hemlock-spruce/fir types that provide snow interception during the time when snows are deep but still fluffy. As soon as these deep snows will support the weight of the caribou with their large hooves, they again move to higher elevations and the lichen diet.

This species may forage and winter in yew habitat. 
The following are other species of concern that may occur in the yew habitat.

Fish

Bull Trout (Salvelinus confluentus)

Steelhead Trout (Oncorhynchus mykiss)

Redband Trout (Oncorhynchus mykiss spp.)

Klamath Large-scale Sucker (Catostomus synderi)

Pit Sculpin (Cottus pitensis)

Slender Sculpin (Cottus tenuis)

Birds

Northern Goshawk (Accipiter gentilis)

Northern Pygmy-owl (Glaucidium gnoma)

Flammulated Owl (Otus flammeolus)

Boreal Owl (Aegolius funereus)

White-headed Woodpecker (Picoides albolarvatus)

Three-toed Woodpecker (Picoides tridactylus)

Harlequin Duck (Histrionicus histrionicus)

Ferruginous Hawk (Buteo regalis)

Upland Sandpiper (Bartramia longicauda)

Tricolored Blackbird (Agelaius tricolor)

Black Rosy Finch (Leucosticte arctoa atrata)

\section{Mammals}

Pacific Fisher (Martes pennanti pacifica)

Marten (Martes americana)

Wolverine (Gulo gulo)

Northern Flying Squirrel (Glaucomys sabrinus)

River Otter (Lutra canadensis)

North American Lynx (Felis lynx canadensis)

Preble's Shrew (Sorex preblei)

Pacific Western Big-eared Bat (Plecotus townsendii townsendii)

White Footed Vole (Arborimus albipes)

California Wolverine (Gulo gulo luteus)

California Bighorn (Ovis canadensis californiana) 


\section{Plants}

Triangular-lobed Moonwort (Botrychium ascendens)

Crenulate Moonwort (Bortrychium crenulatum)

Clustered Lady's Slipper (Cypripedium fasciculatum)

Constance's Bittercress (Cardamine constancei)

Case's Corydalis (Corydalis caseana spp. hastata)

Bank Monkeyflower (Mimulus clivicola)

Idaho Strawberry (Waldsteinia idahoensis)

Deer-fern (Blechnum spicant)

Pacific Dogwood (Cornus nuttallii)

Leiberg's Tauschia (Tauschia tenuissima)

Plumed Clover (Trifolium plumosum var. amplifolium)

Soft Rush (Juncus effusus var. pacificus)

Hall's Rush (Juncus halli)

False Lilly-of-the-valley (Maianthemum dilatatum)

Bank Monkey Flower (Mimulus clivicola)

Jessica's Aster (Aster jessicae)

Piper's Bug-on-a-stick (Buxbaumia piperi)

Henderson's Sedge (Carex hendersonii)

Short-spored Jelly Lichen (Collema curtisporum)

Small Yellow Lady's Slipper

(Cyrpripedium acaulis var. parviflorum)

Henderson's Shooting-star (Dodecatheon hendersonii)

Fringed Pinesap (Pleuricospora fimbriolata)

(Abronia umbellata spp. breviflora)

(Agoseris elata)

(Agrostis borealis)

(Agrostis howellii)

(Allium bolanderi)

(Allium geyeri var. geyeri)

(Allium madidum)

((Antennaria aromatica)

(Antennaria corymbossa)

(Arabis furcata)

(Arabis sparsiflora var. atrorubens)

(Asarum wagneri)

(Asplenium septentrionale)

(Asplenium viride)

(Bensoniella oregona)

(Bolandra oregana)

(Botrychium ascendens) 
Plants (Cont.)

(Botrychium crenulatum)

(Botrychium lanceolatu,)

(Botrychium lunaria)

(Botrychium minganense)

(Botrychium montanum)

(Botrychium pedumculosum)

(Botrychium pinnatum)

(Botrychium pumicola)

(Botrychium simplex)

(Bupleurum americanum)

(Calamagrostis breweri)

(Calochortus howellii)

(Calochortus longebarbatis var. longebarbatus)

(Calochortus nudus)

(Calochortus umpquaensis)

(Cardamine gemmata $=[$ Dentaria gemmata $]$ )

(Cardamine pattersonii)

(Carex atrata var. erecta)

(Carex buxbaumii)

(Carex comosa)

(Carex concinna)

(Carex macrochaeta)

(Corydalis aquae-gelidae)

(Erigeron howellii)

(Erigeron oreganus)

(Erythronium elegans)

(Erythronium revolutum)

(Fillipendula occidentalis)

(Frasera umpquaensis)

(Fritillaria campschatcensia)

(Fritillaria glauca)

(Gentiana glauca)

(Gentiana plurisetosa $=[$ Gentiana setigera $]$ )

(Hackelia diffusa var. diffusa)

(Hieracium longiberbe)

(Lewisia columbiana spp. columbiana)

(Lewisia cotyledon var. purdyi)

(Lewisia leana)

(Lewisia oppositifolia)

(Lobelia dortmanna) 
Plants (Cont.)

(Lycopodium annotinum)

(Lycopodium complanatum)

(Lycopodium selago)

(Microseris borealis)

(Microseris howellii)

(Microseris laciniata spp. detlingii)

(Monardella purpurea)

(Montia diffusa)

(Navarretia tagetina)

(Ophioglossum vulgatum)

(Oxypolis occidentalis)

(Penstemon barrettiae)

(Perideridia erythrorhiza)

(Perideridia howellii)

(Phlox hendersonii)

(Platanthera obtusata [syn: Habenaria obtusata])

(Poa laxiflora)

(Poa piperi)

(Polystichum californicum)

(Potentillia villosa var. parviflora)

(Romanzoffia thompsonii)

(Rorippa columbiae)

(Scheuchzeria palustris var. americana)

(Sedum laxum spp. heckneri)

(Sedum oblanceolatum)

(Sedum spathulifolium spp. purdyi)

(Senecio hesperius)

(Sidalcea hirtipes)

((Sisyrinchium sarmentosum)

(Smilax californica)

(Sophora leachiana)

(Spiranthes romanzoffiana var. porrifolia)

(Streptopus streptopoides)

(Sullivantia oregana)

(Tauschia howellii)

(Tauschia stricklandii)

(Triteleia hendersonii var. leachiae) 
Amphibians and Reptiles

Couer d'Alene Salamander (Plethodon vandykei idahoensis)

Wood Frog (Rana sylvatica)

Cope's Giant Salamander (Dicamptodon copei)

Del Norte Salamander (Plethodon elongatus)

Larch Mountain Salamander (Plethodon larselli)

Siskiyou Mountain Salamander (Plethodon stormi)

Red-legged Frog (Rana auroa)

Common Kingsnake (Lampropeltis getulus)

California Mountain Kingsnake (Lampropeltis zonata)

Invertebrates

Wahkeena Falls Flightless Stonefly (Nemoura wahkeena)

Beer's False Penny Beetle (Acneus beeri)

Burnell's False Penny Beetle (Acneus bernelli)

Mt. Hood Primitive Caddisfly (Eobrachycentrus gelidae)

Denning's Agapetus (Agapetus denningi)

Schuh's Homoplectran Caddisfly (Homoplectra schuhi)

Alsea Micro Caddisfly (Ochrotrichia alsea)

Fischer's Caddisfly (Lepidostoma fischeri)

Cascades Apatanian Caddisfly (Apatania tavala)

Blue Mountain Cryptochian (Crypotchia neosa)

Green Springs Mt. Caddisfly (Farula davisi)

Mt. Hood Farulan (Farula jewetti)

Tombstone Prairie Caddisfly (Farula reaperi)

Ft. Dick Limnephilus Caddisfly (Limnephilus atercus)

Columbia Gorge Caddisfly (Nepthremma adnersoni)

Tombstone Prairie Caddisfly (Oligophlebodes mosthento)

Haddock's Caddisfly (Rhyacphila Haddoki)

One-spot Caddisfly (Rhyacphila unipunctata)

Siskiyou Caddisfly (Tinodes siskiyou) 


\begin{tabular}{|c|c|c|c|}
\hline Wildlife & Common Name & Scientific Name & \multirow{7}{*}{$\begin{array}{l}\text { Other Common } \\
\text { and Scientific } \\
\text { Names Used in } \\
\text { the Wildlife } \\
\text { Sections }\end{array}$} \\
\hline Amphibians & \begin{tabular}{|l|} 
Olympic salamanders \\
Tailed frog \\
\end{tabular} & \begin{tabular}{|l|} 
Rhyacotriton olympicus \\
Ascaphus truei
\end{tabular} & \\
\hline Mammals & $\begin{array}{l}\text { Black-tailed deer } \\
\text { Deer } \\
\text { Elk } \\
\text { Fisher } \\
\text { Moose } \\
\text { Mountain beaver } \\
\text { Mule deer } \\
\text { Racoon } \\
\text { Snowshoe hare } \\
\text { Townsend's vole }\end{array}$ & $\begin{array}{l}\text { Odocoileus hemionus } \\
\text { Odocoileus spp. } \\
\text { Cervus elaphus } \\
\text { Martes pennanti } \\
\text { Alces alces } \\
\text { Aplodontia rufa } \\
\text { Odocoileus hemionus } \\
\text { Procyon lotor } \\
\text { Lepus americanus } \\
\text { Microtus townsendii }\end{array}$ & \\
\hline Birds & $\begin{array}{l}\text { American goldfinch } \\
\text { Hermit thrush } \\
\text { Orange-crowned warbler } \\
\text { Song sparrow } \\
\text { Townsend's solitaire } \\
\text { Varied thrush } \\
\text { Western bluebird } \\
\text { Western meadowlark } \\
\text { White-crowned sparrow }\end{array}$ & $\begin{array}{l}\text { Carduelis tristis } \\
\text { Catharus guttatus } \\
\text { Vermivora celata } \\
\text { Melospiza melodia } \\
\text { Myadestes townsendi } \\
\text { Ixareus naevius } \\
\text { Sialia mexicana } \\
\text { Sturnella neglecta } \\
\text { Zonotrichia leucophrys }\end{array}$ & \\
\hline Coniferous Trees & $\begin{array}{l}\text { Douglas-fir } \\
\text { Grand fir } \\
\text { Pacific yew }\end{array}$ & $\begin{array}{l}\text { Pseudotsuga menziesii } \\
\text { Abies grandis } \\
\text { Taxus brevifolia }\end{array}$ & \\
\hline Shrubs and Herbs & Umatilla gooseberry & $\begin{array}{l}\text { Ribes oxyacanthoides } \\
\text { cognatum }\end{array}$ & \\
\hline Ferns & Male fern & Dryopteris filix-mas & \\
\hline
\end{tabular}


Environmental Consequences for Animals and Plants
The following provides additional detail and background information on the potential effects of yew harvest on animals and special status plants.

\section{Species Associated With Late-Successional Forests}

The yew harvest program would not change the amount of latesuccessional forest habitat. However, harvesting yew in latesuccessional forests would change the character of the habitat, and could affect some species. These are poorly understood relationships, and the degree to which this would happen is unknown for most species. In the absence of detailed information on the habitat relationships of species associated with late-successional forests, the effects of yew harvest is assumed to be related to potential effects on animals and other plants. Species for which additional information is available, such as moose, are discussed individually following the general discussion.

\section{Forest Structure and Composition}

Alternatives that harvest yew outside of clearcut/shelterwood/ seed tree timber sale areas would result in changes in the structure and composition of late-successional forest habitats where the harvest occurs. Yew harvest would affect multilayered forest canopies and plant species diversity, two habitat components that may enhance animal species diversity in late-successional forests. Multilayered stands and stands with higher plant species diversity are considered to be valuable to wildlife because they are believed to support more diverse animal communities. Research has shown that multilayered forest habitats at least sometimes support more diverse bird communities (MacArthur and MacArthur, 1961).

The Interim Guide to the Conservation and Management of Pacific Yew (USDA Forest Service, 1992a) assumes that 30 to 50 percent of the midstory could be removed without a significant risk of reducing the abundance and fitness of vertebrates using the area. This is based on findings in a study in the Oregon coast range that removing about 30 percent of the Douglas-fir overstory 
in half-acre patches did not have appreciable short-term effects on small birds or mammals (USDA Forest Service, 1992). In areas where dense patches of yew make up a higher proportion of the midstory layer, effects on animal and other plant populations and communities may be greater than in areas where other plant species contribute more to the midstory vegetation.

Either bark or needle harvest could affect the structural and functional role of yew in late-successional forests. The contribution that yew makes to multilayered canopies and the way in which animals use yew is often a function of its growth form. Direct effects of needle harvest would be to remove part of the midstory canopy. This would probably have minor effects on wildlife in most areas, where yew growth form is open. In areas where the growth form is denser, needle harvest could have greater effects. The effects are still likely to be minor unless large areas are harvested. Indirect effects would be long-term changes in growth form that might be beneficial for some species and detrimental to others.

Other habitat components of late-successional forests include large trees, snags and logs. These would be less affected by yew harvest. The large tree component would not be affected by yew harvest since the Pacific yew is a smaller understory tree species where it occurs in late-successional forests.

Yew snags would not generally be directly affected by harvest in late-successional forests. At this time, yew harvest focuses on live or recently dead yew trees and shrubs. However, the harvest of live trees would reduce the number of snags that might be available in the future. A very small proportion of all snags are Pacific yew. Species using snag habitat that is not related to a particular species of tree would not be significantly affected by yew harvest. There are no species currently known to depend on yew snags. The effects of the alternatives on such species, if they exist, are unknown. Most of the wildlife-snag relationships that have been identified indicate that larger diameter and taller snags have a greater value for cavity users. Since yew snags tend to be relatively short, with relatively small diameters, it is assumed that their value to cavity users is low. 
Yew logs are relatively small and scarce in most areas, compared to those of other species, but their extremely slow rate of decay makes them rather unique. Yew harvest could result in additional yew wood being left in non-timber sale areas. These additional logs would be unlike naturally occurring logs in that they would be peeled, cut into pieces and, possibly, piled. The effects of these changes to wildlife are unknown, but the abundance of some species may increase with increasing numbers of yew logs. For example, yew slash might benefit some species such as some amphibians, reptiles, small mammals, and small carnivores. Where yew is abundant, large quantities of logs and branches left on the ground could impede movements of some species such as deer and elk. The role of yew logs in streams and riparian areas is discussed below (and in the water quality section).

\section{Moose and Other Ungulates}

Yew harvest in old growth grand fir/Pacific yew forests on moose winter range in northern Idaho would affect forage quantity and forage availability as a result of snow interception and thermal cover. Yew harvest would result in an increase in forage two years after harvest, but this would not be available to moose if the combined canopy coverage of the overstory grand fir and understory yew was not great enough to intercept the snow. The loss of thermal cover could put additional stress on moose during severe winter weather.

Although yew is a preferred browse species and, at times, provides thermal and hiding cover, deer and elk are opportunistic in their feeding habits and do not depend heavily on yew in most areas. There may be site-specific situations where yew is particularly important to local deer or elk populations for food or cover.

High open road densities have significant effects on ungulates due to disturbance by traffic, reduction in habitat availability adjacent to roads, and increased vulnerability of animals to legal and illegal harvest. If additional road building or opening of currently closed roads occurs in connection with yew harvest and leads to higher open road densities, deer, elk and moose would be subject to greater stress, their distribution could become more 
restricted, and their abundance could decline. If yew harvest occurs in fawning or calving areas, disturbance could result in increased fawn and calf mortality rates. In areas with abundant yew, material left after harvest could interfere with animal movements.

\section{Other Species}

Note: An in-depth discussion of the effects of yew harvest on spotted owls is included at the end of this section.

It is assumed that yew fruit is important to fruit-eating rodents and birds only sporadically over space and time because fruit production is patchy over the landscape (USDA, 1992) and fruiteating species are not limited to areas with yew. In areas where yew is abundant, removal of large amounts of yew could affect these species. Although yew harvest probably would not eliminate fruit-eating species from an area, population numbers or the survival of offspring could be reduced in areas where fruit is abundant. In turn, this could affect other species that prey on the fruit eaters.

Human activity associated with yew harvest could disturb some species of wildlife. The level of disturbance would depend on various factors, including sensitivity of the species, season of year, importance of the site to the animal (e.g., nesting or calving site), number of yew harvesters, and duration of yew harvest.

\section{Cumulative Effects}

There are significant risks, in terms of effects on wildlife and other plants, associated with a program which would harvest yew all across the landscape in only a few years (e.g. the four-five years projected in this EIS). The knowledge that we currently have about the relationships of Pacific yew to other species is extremely limited. For example, the descriptions of what constitutes good quality winter range for moose on the $\mathrm{Nez}$ Perce National Forest in northern Idaho are from very limited study, and more research has been done on moose/yew relationships than for any other species or group of species. 
If yew is harvested at the specified harvest levels on all of the available acres, the effects on wildlife diversity may be substantially greater than if only a portion of the acres are harvested. Options for selecting harvest areas would be limited if harvesting was done on all acres available under existing forest plans or BLM resource management plans. For example, harvest in an area where yew makes up a greater proportion of the midstory vegetation probably has greater effects than harvest in an area where other tree species provide a significant proportion of that layer. Harvest at the prescribed level over all acres that meet the minimum requirements could result in the removal of some habitat features from the landscape. For example, if all thick clumps of yew were thinned or removed, animals that depend on thick clumps would be significantly affected on a broad landscape scale. These aspects of wildlife ecology are complex, difficult to study, and poorly understood.

An intensive program to harvest yew over large areas in the short time frame of a few years would have significant effects on ungulates and other species sensitive to human disturbance. Increased traffic and increased densities of open roads could substantially reduce effective ungulate habitat in some areas. Many roads would probably have to be opened to accommodate yew harvesters and use of those roads by yew harvesters and others would increase. A substantial increase in people working throughout the forest would also disturb ungulates and other wildlife species. Since much of the yew harvest season overlaps with calving and fawning seasons, increased human activity in calving and fawning areas would cause disturbance at a sensitive time of year. These stresses could result in poor animal condition and increased mortality. Other species that avoid human contact could be similarly affected.

Moderate to high levels of yew harvest could have unforeseen effects on some species of wildlife or plants that might not be recognized until serious habitat loss has occurred. The compressed time frame of this program, combined with our lack of knowledge about the role of Pacific yew in the ecosystem, makes it difficult to recognize such effects early enough to identify the mechanisms of population declines and find remedies. The likeli- 
hood of this occurring is unknown. Although it is unlikely that there is an obligatory relationship between yew and most vertebrate species (USDA Forest Service, 1992a), yew may be important to some vertebrates and invertebrates in ways that have not been identified.

\section{Alternatives and the Northern Spotted Owl}

Pacific yew may or may not be a component of spotted owl habitat, and when present, density, size, age, and percent of Pacific yew relative to other understory species varies widely from site to site within the range of the spotted owl. (For information on Pacific yew native range in combination with Northern spotted owl range, see Figure J-1.) Where yew is abundant, it plays a greater role in owl habitat than in those sites where it is uncommon. In sites with a mixture of midstory plant species, other species may substitute, at least to some extent, for yew removed by harvest.

When present in the midstory, Pacific yew is often used for roosting by both adult and young spotted owls. Yew may also play a role as habitat for any number of important prey species.

Although there is an absence of data, it is generally felt that some proportion of a stand can be removed without causing significant habitat changes for vertebrate species. Conversely, if a large percentage of the stand is removed, especially in areas where yew is abundant, the stand structure may be changed enough to cause a reduction in or loss of vertebrate species (USDA Forest Service, Interim Guide, 1992). Spotted owl habitat would probably not be impacted by the harvest of needles, provided the tree is not killed.

\section{Effect on Prey Species}

Pacific yew is closely associated with late successional stage forests and riparian situations throughout its range. A large number of animal species, some of which are prey species for owls, are also associated with these same late successional stage and riparian situations. The northern flying squirrel, bushy-tailed wood rat, red tree vole, and red-backed vole are examples of prey species associated with these sites. 
No studies currently are available that describe the relationship between prey species and Pacific yew. It is known, however, that yew of varying height and age helps to create a multi-layered forest that provides perches, dispersal opportunities and travel routes for arboreal mammals. (Carey et al., 1991) reports that some arboreal mammals, such as the red tree vole, move almost exclusively through the canopy and are reliant on a closed and layered canopy for food sources, feeding cover, predation cover, and dispersal or other movement.

\section{Alternatives}

Alternatives $A$ and $B$ have the least impact because they propose little (Alt. B) or no (Alt. A) habitat disturbance in addition to that normally occurring from implementing forest or resource management plans. Alternative B does remove yew, but only after (or shortly before) the overstory has been removed by timber harvest. The greatest impact occurs with the removal of the overstory. Alternative $B$ requires regeneration of yew following harvest, and has fewer long-term impacts than Alternative A.

Alternatives C, D, and F provide for harvesting yew from non-sale areas and thinning units, as well as from timber harvest areas. These alternatives have a greater potential to impact spotted owl prey habitat because they permit harvest in extensive areas of currently suitable owl habitat. Forest plans and BLM resource management plans provide that many of these non-sale areas will be scheduled for timber harvest at some point in the future. Alternatives C, D, and F, however, will accelerate the impact on understory vegetation by removing a portion of yew before the scheduled timber harvest. Impacts increase with the percentage of yew removed. The impacts of Alternative G1 would be similar to those of Alternative D but more total acres would be involved because of reduced leave tree requirements.

Alternative G2, in addition to providing yew harvest from sale areas and non-sale areas, provides for harvest from Owl Conservation Areas (OCAs) and has the greatest potential for impacting spotted owl prey habitat because the largest area is available for harvest. 
In addition, harvest within Owl Conservation Areas conflicts with direction stated in the "Final Environmental Impact Statement for the Management of the Northern Spotted Owl in the National Forests," and in "A Conservation Strategy for the Northern Spotted Owl." The goal for Owl Conservation Areas is to "maintain, over the forest landscape, a population of northern spotted owl that has a high probability of continued existence throughout its range."

\section{Effect on Roosting Habitat}

During the warm summer months, northern spotted owl roost sites are usually cool shady sites located near streams on the lower one-third of slopes. Owls tend to roost low in the forest understory in small trees and shrubs (Forsman, 1976; Solis, 1983). Spotted owls respond to variations in temperature and exposure by moving within the canopy to find favorable conditions (Forsman 1976; Barrows and Barrows, 1978; Forsman, 1980; Barrows, 1981; Solis, 1983; Forsman et al., 1984). By roosting in the shade of the understory during the warm weather, owls reduce their exposure to high temperatures and solar radiation (Forsman, 1976; Barrows and Barrows, 1978) and may reduce the metabolic energy required for thermoregulation (Forsman, 1980).

Pacific yew commonly serves as a roost site, and facilitates movement through the understory. No information currently is available concerning the size, amount, and distribution of Pacific yew occurring in summer roost areas. The effects of yew removal have not been evaluated through formal study.

Intuitively, the greatest effect can be expected in summer roost areas where yew is the dominant understory species and where a large percentage of the large size class $\left(>11^{\prime \prime} \mathrm{DBH}\right)$ of trees are removed. Lesser and perhaps minor impacts can be expected where summer roosting does not occur or where understory vegetation is abundant and varied and when smaller $\left(<11^{\prime \prime} \mathrm{DBH}\right)$ yews are harvested.

Alternatives A and B would have no effect on roosting habitat. Alternative A does not harvest yew and Alternative B harvests 
Wildlife and

Biological

Assessment

Figure J-1: Pacific Yew Native Range and Northern Spotted Owl Range
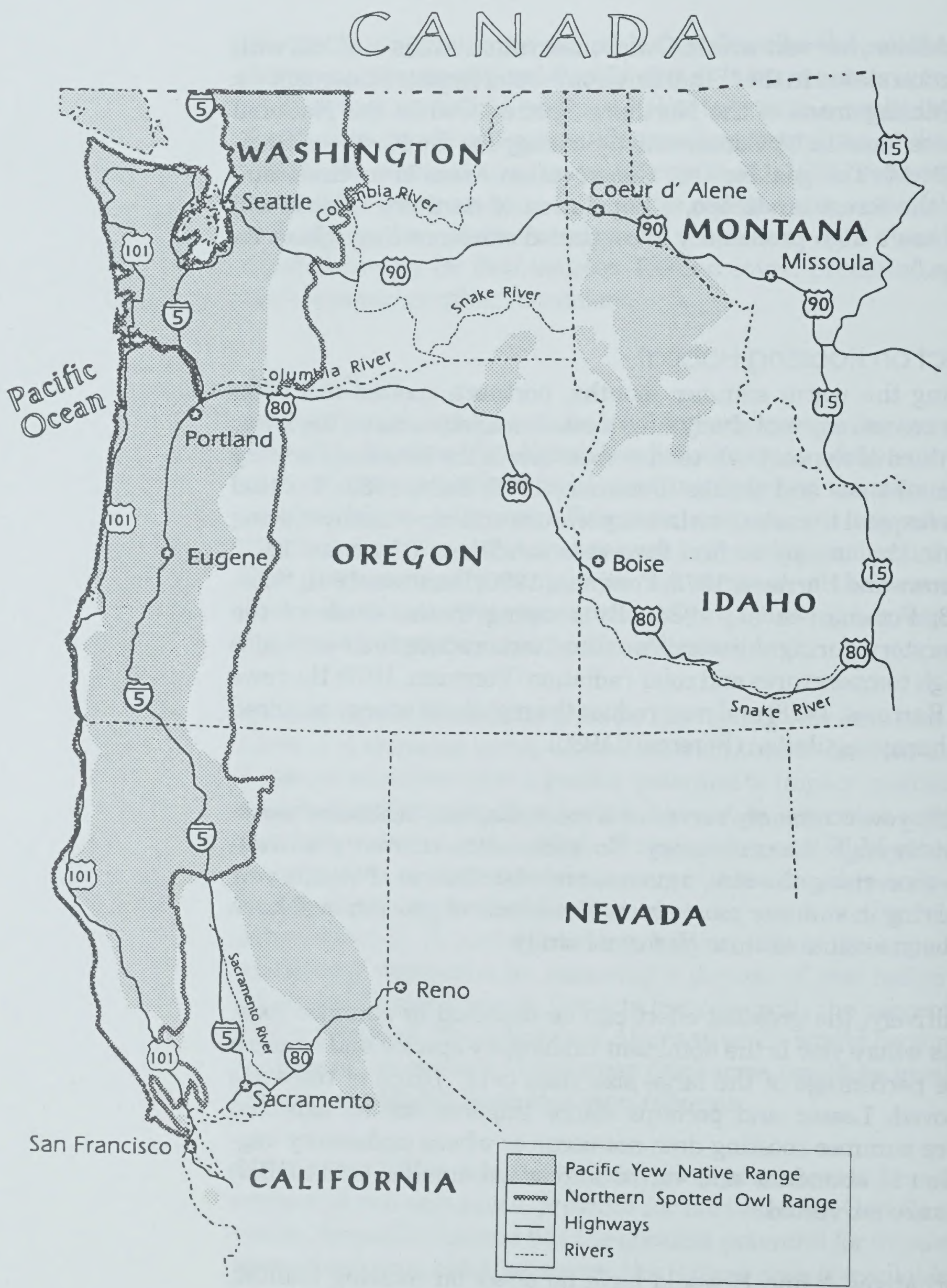
from timber sale units. Sale units are not suitable habitat following the harvest of the overstory stand.

Alternatives $\mathrm{C}, \mathrm{D}$, and $\mathrm{F}$ allow yew harvest in non-sale areas. These alternatives have a greater potential to reduce the quality of roosting habitat in areas of suitable habitat outside of OCAs. Many of the current non-sale areas will be scheduled for timber harvest in the future, but these alternatives will allow removal of part of the multistoried stands in the interim before final harvest. The impacts of Alternative G1 would be similar, but somewhat greater than Alternative $\mathrm{D}$ because the reduced leave tree requirements will increase the total acres where yew harvest can occur. Impacts increase with the percentage of yew harvested and where Pacific yew is the dominant understory species.

In addition to providing yew harvest in sale areas and selected nonsale areas, Alternative G2 allows yew to be removed from Owl Conservation Areas, and because of this, has the greatest potential of impacting roosting habitat of any of the alternatives. Loss of habitat or habitat quality in the Owl Conservation Areas may have long-term effects and could reduce the productivity of some OCAs.

In addition, harvest within OCAs conflicts with the direction prescribed in "A Conservation Strategy for the Northern Spotted Owl" and the "EIS for Management of the Spotted Owl in the National Forests." The conservation strategy states in part, "Activities within OCAs should be consistent with their primary management prescription to ensure that owls in OCAs have high probability of persistence (details in appendices $\mathrm{O}$ and $\mathrm{Q}$ ). In particular, forests in OCAs should be maintained in superior habitat condition for owls, and younger forest and logged sites should be allowed to mature into superior habitat." 


\section{References A}

Abrams, L. 1984. Illustrated flora of the Pacific states (Washington, Oregon, and California). Stanford University Press. 4 Volumes.

Anderson, D.R.; Bart, J.; Edwards Jr., T.C.; (and others). 1990. Status review: northern spotted owl Strix occidentalis caurina. U.S. Department of the Interior, Fish and Wildlife Service. 99 p.

Andreasen, J.K. 1975. Systematics and status of the family Catostomidae in southern Oregon. Corvallis: Oregon State University. 76 p. Ph.D. thesis.

B

Barrows, Cameron W. 1981. Roost selection by spotted owls: an adaptation to heat stress. Condor. 83(4):302-309.

Barrows, C.; Barrows K. 1978. Roost characteristics and behavioral hermoregulation in the spotted owl. Western Birds 9:1-8.

Bienz, C.S.; Ziller, J.S. 1987. Status of three lacustrine sucker species (Catostomidae). Sacramento, CA: Report to the U.S. Fish and Wildlife Service. 39 p.

Bjorge, R.R. 1982. Biology, habitat, and management of woodland caribou on the Redrock-Chicken Creek winter range in west central Alberta. Paper presented at the Northwest section of the Wildlife Society Meeting. Juneau, AK.

Bloomfield, M. 1979. Patterns of seasonal habitat selection exhibited by woodland caribou in central British Columbia, Canada. In: Proceeding of the 2nd International Reindeer/ Caribou Symposium. Roros, Norway.

Brown, Don L. 1982. Grizzly bear recovery plan. Denver, CO: U.S. Department of the Interior, Fish and Wildlife Service. $195 \mathrm{p}$.

Buettner, M.; Scoppettone, G. 1990. Life history and status of Catostomids in Upper Klamath Lake, Oregon. U.S. Fish and Wildlife Service Completion Report. 108 p. 
C

Carey, A.B. 1991. The biology of arboreal rodents in Douglas-fir forests, In: Huff, M.H.; Holthausen, R.S.; Aubry, K.B., tech. coords. 1991. Biology and management of old growth forests. Gen. Tech. Rep. PNW-GTR-276. Portland, OR: USDA Forest Service, Pacific Northwest Research Station. 46 p.

Coots, M. 1965. Occurrences of the Lost River Sucker, Deltistes Luxatus (Cope), and shortnose sucker, Chasmistes brevirostris (Cope), in northern California. California Fish and Game. 51: 68-73.

Cronquist, A.; Holmgren, A.H.; Holmgren, N.H.; [and others]. 1986. Intermountain flora - vascular plants of the intermountain west, U.S.A. 6 volumes. The New York Botanical Garden.

D

Darby, W.R. 1979. Seasonal movements, habitat utilization, and population ecology of woodland caribou (Rangifer tarandus caribou Gemlin) in the Wallace-Aikens Lake region of southeastern Manitoba. Winnipeg: University of Manitoba. 187 p. M.S. Thesis.

Dawson, W.R.; Ligon, J.D.; Murphy, J.R.; Myers, J.P.; Simberloff, D.; Verner, J. 1986. Report of the advisory panel on the spotted owl. Audubon Conserv. Report 7. $46 \mathrm{p}$.

Detrich, P.J. 1986. Status and distribution of the bald eagle in California. Chico: California State University. M.S. Thesis.

E

Evans, H.F. 1960. A preliminary investigation of caribou in the northwestern United States. Missoula: University of Montana. 145 p. M.S. Thesis.

F

Forsman, Eric D. 1976. A preliminary investigation of the spotted owl in Oregon. Corvallis: Oregon State University. 127 p. M.S. Thesis. 
Forsman, Eric D. 1980. Habitat utilization by spotted owls in the west-central Cascades of Oregon. Corvallis: Oregon State University. 95 p. Ph.D. Thesis.

Forsman, E.D., Meslow,E.C., and Wight, H.M. 1984. Distribution and biology of the spotted owl in Oregon. Wildlife Mono. No. 87. 64 pp.

Franklin, I.R. 1980. Evolutionary changes in small populations. Chapter 8. In: Soule, Michael E.; Wilcox, Bruce, eds. Conservation biology, an evolutionary ecological perspective. Sunderland, Mass: Sinauer Associates. 396 p.

H

Hall, E.R. 1981. The mammals of North America. New York: John Wiley \& Sons. 2 volumes.

Hitchcock, L.C.; Cronquist, A. 1990. Flora of the Pacific Northwest, an illustrated manual. Seattle: University of Washington Press.

Hoffman, R.S.; Pattie, D.L. 1968. A guide to Montana mammals: identification, habitat, distribution and abundance. Missoula: University of Montana. 133 p.

I

Issacs, F.B.; Anthony, R.G. 1990. Bald eagle nest locations and history of use in Oregon, 1971-1990. Unpublished report. Oregon Cooperative Research Unit, Department of Fish and Wildlife. Corvallis: Oregon State University.

$J$

Jerry, D.G. 1983. Old growth management in the Idaho Panhandle National Forest. U.S. Department of Agriculture, Forest Service. Mimeograph. 39 p.

Johnson, D.R. 1976. Mountain Caribou: Threats to survival in the Kootenay Pass region, British Columbia. Northwest Science. 53(2): 114-117. 
Johnson, D.R.; Miller, D.R.; Peek, J.M. 1981. Guidelines for human activity within the range of woodland caribou, southern Selkirk Mountains. Forest Wildlife and Range Experiment Station. University of Idaho. Misc. Publication. Number $3.7 \mathrm{p}$.

K

Klamath River Basin Fisheries Task Force. 1991. Long range plan for the Klamath River Basin conservation area fishery restoration program. Yreka, CA: U.S. Fish and Wildlife Service.

Koehler, G.M. 1990. Demographic and habitat characteristics of lynx and snowshoe hare in north-central Washington. Canadian Journal of Zoology. 68: 845-851.

\section{M}

Matthews, Gene M.; Waples, Robin S. 1991. Status review for Snake River spring and summer Chinook salmon. U.S. Department of Commerce. National Oceanic and Atmospheric Administration. National Marine Fisheries Service.

Mech, L.D. 1989. Wolf population survival in an area of high road density. Am. Midl. Nat. 121: 387-389.

Meinke, Robert J. 1982. Threatened and endangered vascular plants of Oregon: an illustrated guide. U.S. Department of the Interior, Fish and Wildlife Service. Corvallis: Oregon State University. 352 p.

Moyle, P.B. 1976. Inland fishes of California. Berkeley, CA: University of California Press. 405 p.

\section{N}

Newton, I. 1979. Population ecology of raptors. Vermillion, SD:

Buteo Books. 
Reel, S.; Schassberger, L; Ruediger, W. 1989. Caring for our natural community, Region 1, threatened, endangered, and sensitive species program. U.S. Department of Agriculture, Forest Service. 309 p.

Rosenberg, K.V.; Raphael, M.G. 1986. Effects of forest fragmentation on vertebrates in Douglas-fir forests. In: Verner, J.; Morrison, M.L.; Ralphs, C.J., eds. Wildlife 2000: modeling habitat relationships of terrestrial vertebrates. Madison, WI: University of Wisconsin Press.

$S$

Scoppetone, G.G.; Vinyard, G.L. 1991. Life history and management of four lacustrine suckers. In: Minckley, W.L.; Deacon, J.E. Battle against extinction - native fish management in the American west. Tucson: University of Arizona Press. P. 369-387.

Snow, C. 1973. Habitat management series for endangered species report No. 5: southern bald eagle and northern bald eagle. U.S. Department of the Interior, Bureau of Land Management. Technical report number 171 .

Solis, David M. 1984b. Summer habitat ecology of spotted owls in northwestern California. Arcate, CA: Humboldt State University. 168 p. M.S. Thesis.

Spahr, Robin; Armstrong, Lori; Atwood, Duane; Rath, Mike. 1991. Threatened, endangered, and sensitive species of the Intermountain Region. Ogden, Utah: U.S. Department of Agriculture, Forest Service.

Stalmaster, M.V.; Newman, J.R. 1976. Behavioral responses of wintering bald eagles to human activity. J. Wildl. Mgmt. 42: 506-513.

Steenhof, K. 1990. The status of bald eagles in the Pacific Recovery Region in relation to recovery goals. Raptor Research and Technical Assistance Center. Boise, ID: U.S. Department of the Interior, Bureau of Land Management. 
Thomas, J.W.; Forsman, E.D.; Lint, J.B. (and others). 1990. A conservation strategy for the northern spotted owl. Portland, OR: A report by the Interagency Scientific Committee to address the conservation of the northern spotted owl. USDA Forest Service; USDI Bureau of Land Management, Fish and Wildlife Service, National Park Service. $427 \mathrm{p}$.

U

U.S. Department of Agriculture, Forest Service; U.S. Department of the Interior, Fish and Wildlife Service.

1981. Plan for coordination of land management activities on the Continental Divide wolf coordination area. Unpublished report.

U.S. Department of Agriculture, Forest Service. $1988 b$. Spotted owl guidelines. In: Final supplement to the environmental impact statement for an amendment to the Pacific Northwest regional guide. USDA, Forest Service, Pacific Northwest Region. Vol. 1.

U.S. Department of Agriculture, Forest Service. 1992. An Interim Guide to the Conservation and Management of the Pacific Yew. Pacific Northwest Region, Portland, OR.

USDA, Forest Service. 1992. Final environmental impact statement on management of the northern spotted owl in the national forests. Washington, D.C.; U.S. Department of Agriculture, Forest Service.

\section{U.S. Department of Commerce, National Oceanic and} Atmospheric Administration. National Marine Fisheries Service. 1991. Factors for decline - A supplement to the notice of determination for Snake River fall Chinook salmon under the Endangered Species Act. 55 p.

U.S. Department of Commerce, National Oceanic and Atmospheric Administration. National Marine Fisheries Service. 1991. Factors for decline - a supplement to the notice of determination for Snake River spring/summer Chinook salmon under the Endangered Species Act. 72 p. 
U.S. Department of Commerce, National Oceanic and Atmospheric Administration. 1991. Endangered and threatened species; endangered status for Snake River Sockeye salmon. $7 \mathrm{p}$.

U.S. Department of the Interior, Fish and Wildlife Service. 1982. Pacific coast recovery plan for the American peregrine falcon. Portland, OR: U.S. Fish and Wildlife Service.

U.S.D.I., Fish and Wildlife Service. 1984. Selkirk Mountain caribou management plan/recovery plan. $118 \mathrm{p}$.

U.S. Department of the Interior, Fish and Wildlife Service. 1986. Pacific Bald Eagle Recovery Plan. Portland, OR: U.S. Fish and Wildlife Service. 118 p.

U.S. Department of the Interior, Fish and Wildlife Service. 1987. Northern Rocky Mountain wolf recovery plan. Denver, CO: U.S. Fish and Wildlife Service. 119 p.

U.S. Department of the Interior, Fish and Wildlife Service. 1989. The northern spotted owl: a status review supplement. Portland, OR. $114 \mathrm{p}$.

U.S. Department of the Interior, Fish and Wildlife Service. $1990 \mathrm{~b}$. Draft grizzly bear recovery plan. U.S. Fish and Wildlife Service. 119 p.

W

Waples, Robin S.; Jones Jr., Robert P.; Beckman, Brian R.; Swan, George A. 1991. Status review for Snake River fall Chinook salmon. U.S. Department of Commerce. National Oceanic and Atmospheric Administration. National Marine Fisheries Service.

Waples, Robin S.; Johnson, Orlay W.; Jones Jr., Robert P. 1991. Status review for Snake River Sockeye salmon. U.S. Department of Commerce. National Oceanic and Atmospheric Administration. National Marine Fisheries Service.

Wydoski, Richard S.; Whitney, Richard R. 1979. Inland fishes of Washington. University of Washington Press. 220 p. 


\section{Cover Letter to U.S. Fish and Wildlife Service}

\section{Roply To: 1950 \\ Dates May 6, 1993}

Mr. John Nues

Blologiet

Fish and wildilfe service

911 NE 11th Ave

Portland, OR 97232-4181

Dear Mr. Muse,

Enclosed 1s the Blological Aseessment for the Paciflc Yew IIS, prepared by Frank Roberts, blologlst on the IIs interdieciplinary team. Ploase review it for eccurecy, for meting your need for a blologlcal opinion, and for meeting the OSDA Forest Service' and OSDI BLM' responsibllities under the Endangered species Act.

At this time I am considering this informal consultation due to the lack of advereo effects to threatened and endangered specles. If your oplnion is different or if you find information thet does indicate edverse effects, plese contect rrank or myeelf and wo will discuse the needed changes. Frank can be reached at (503) 573-7292 or 4334; I can be reached at (503) 326-7755.

I underetand that we can expect alological opinion from you within 30 calendar deye of your recelpt of the BA. Thank you for working with us on this project.

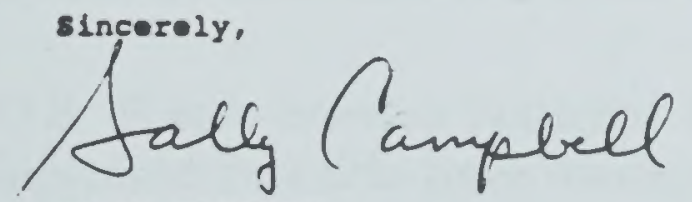

SALLY CNAPBELL

Paclfic Yow IIS Team Leader

CC\& Robert Perent1, TwS-Bolse

Ruse Peterson, Fws-Portland

remper Mckaster, Iis-Belene

Frank Roberte, 75

Grant Gunderton, 8

Rick Roberte, Is
Deve Fredrlck, Fis-Olympis Wayne White, Fis-secramento Cherles Lobde11, Fis-Bolee Kent Iresidder, BLY

Karen W11eon, Fs 


\section{Cover Letter to \\ National Manine \\ Fisheries Service}

\begin{tabular}{|c|c|c|c|}
\hline $\begin{array}{l}\text { Dofted states } \\
\text { Dopartment of } \\
\text { agrieultare }\end{array}$ & $\begin{array}{l}\text { roreet } \\
\text { corv } 100\end{array}$ & $\begin{array}{l}\text { Pacific } \\
\text { Iortbiret } \\
\text { logion }\end{array}$ & $\begin{array}{l}333 \text { E.W. F1ret Aredue } \\
\text { P.0. Dox 3623 } \\
\text { Portland, OR } 97208-3623\end{array}$ \\
\hline
\end{tabular}

roply 20: 1950

Dete: May 6, 1993

Kr. Kerritt Iuttle

Division Chief

Metional Karine Floheries service

911 IE 11th Ave - RoOn 620

Portland, OR 97232

Doar Mr. Iuttle,

Enclosod 1s the slological Assessment for the Paclfic Yow IIS, prepured by Frank Roberts, blologiet on the IS Interdieciplinary team. Please reviow it for accuracy, for beting your needs for a blologicel opinion, and for meting the OSDA Forest servlCe' and OSDI BLM' responelbll1tles under the Indangered spocies net.

At this time I am conaldering this informal coneultation due to the lack of adverse effects to threstened and endangered opecies. If your opinion is different or $1 f$ you find informetion that does indicate adverse effects, please contect Irank or myeell and we w11 diecues the needed changes. Frenk can be rachod at (503) 573-7292 or 4334; I can be reachad at (503) 326-7755.

I understand that, becaune this is a programatic EIS covering several otses, w are exempt frow the interagency procese that is being used for other ections. I look forward to recleving your reopones to the a within 30 calendar daye of your recelpt of the $\mathrm{B}$. Thent you for working with us on tbis project.

incerely,

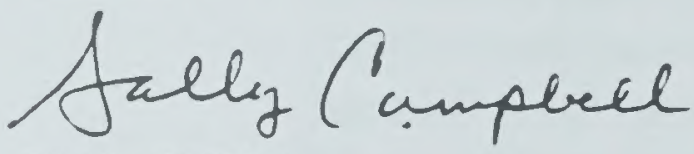

ENLYY CNAPBILL

Pacifle Yow IIS Toas Lader

ce; Cordon Buugen, 88 Rick Roberte, IS Grant Gunderaon, 88
Prask Roberte, PS

ront Irosldder, ILY

raren W11eon, 88 
Contents
Introduction
Description of Proposed Action
Analysis of Effects
Conclusions
Table J-1 - Summary of Threatened,

Endangered and Proposed Species

\section{Introduction}

The purpose of this biological assessment (BA) is to determine, and document, whether the proposed actions listed below are likely to adversely affect the species listed in Table 1 , or adversely modify their habitat. The actions are proposed for calendar years 1993 through 1997 within the range of the listed species (Table 1). The proposed actions involve the following Federal lands: all $19 \mathrm{Na}-$ tional Forests and the Columbia Gorge National Scenic Area in the Pacific Northwest Region; the Clearwater, Kootenai, Idaho Panhandle, Flathead, Lolo, and Nez Perce National Forests in the Northern Region; the Six Rivers, Klamath, Tahoe, Shasta Trinity, Lassen, Eldorado, Mendocino, and Plumas National Forests in the Pacific Southwest Region; the Medford, Salem, Eugene, Roseburg, Coos Bay, Vale, Prineville, and Lakeview Districts of the Bureau of Land Management in Oregon; the Spokane District of the Bureau of Land Management in Washington; the Coeur d'Alene District of the Bureau of Land Management in Idaho; and the Redding, and Ukiah Districts of the Bureau of Land Management in California.

All U.S. Forest Service National Forests and Bureau of Land Management Districts have management plans that were developed to meet the mandates and directions of the Endangered Species Act (ESA) and its implementing regulations.

Information presented in this document is based upon the February 17, 1993 letters sent to U.S. Fish and Wildlife Service and National Marine Fisheries Service requesting updated species lists; numerous telephone calls and meetings; and is the best available Federal data to date. Replies from both Agencies have been used to update the list of Threatened, Endangered, and Proposed species.

\section{Biological \\ Assessmentfor \\ Pacific Yew FEIS}




\section{Description of the Proposed Action}

The proposed action is to harvest Pacific yew from timber sales and the potential of harvesting yew from areas outside of timber sales. This is a modified alternative B; the modification is to make sure some yew would be harvestable if there were no timber sales. Approximately 1.30 to 14.72 million pounds of dry bark is proposed to be available for collection in the five year period. Yew bark would come from timber sales first and then if more bark is needed it could be harvested, up to the limit of 14.72 million pounds of dry bark.

Where yew is harvested from timber sales, an environmental assessment will be done for that specific site. If yew is to be harvested outside of timber sales, a site specific environmental assessment (or decision notice) will need to be completed that looks only at yew harvest and associated activities.

Currently, only bark (rather than needles or wood) is collected from yew for taxol. Needles can be harvested and guidelines for harvesting them are included in the EIS; however, there has been no demand and there is currently no FDA approved process for extracting taxol from needles.

Harvest of yew bark is done by stripping the bark off live yew trees. The bark can be stripped from standing trees or from trees that are felled by the bark stripper. The bark is stripped from all the trunk and limbs down to one inch diameter. Where it is possible, the yew tree is felled and the bark is stripped prior to timber harvest. Yew bark is harvested in the spring and early summer when there is more available taxol in the bark, and the bark is easier to strip. At other times of the year the lack of fluid in the bark reduces the taxol content and causes the bark to stick to the tree. Yew bark can be harvested as soon as the sap starts flowing in the spring, depending on access conditions. The stripped bark is packed out to a road by human, animal, or, where access is possible by all terrain vehicles. 


\section{Analysis of the Effects of the Action}

\section{A. General Description}

Timber sales which occur in yew habitat have the potential to adversely affect yew and adversely modify their habitat. The removal of yew and the modification of the habitat may affect associated animal species. A variety of harvest prescriptions are utilized to cut timber. Regeneration harvests, such as clearcuts and shelterwoods, eliminate yew habitat in the actual cutting unit and serve to fragment remaining habitat. Other prescriptions such as partial overstory removal and some types of salvage have less impact on the suitability of the stand following the sale activity, but could still remove all the yew in the area. The severity of the impact is affected by numbers of trees removed, total acreage involved, condition of the stand prior to harvest, and method of harvest. These can range from essentially no effect in the case of the removal of a hazardous tree near a road or removal of a portion of the down trees in a blow down to the elimination of the stand, in the case of a overstory removal.

The harvest of yew bark from a timber stand that will be receiving timber harvest activities has minor effects to the habitat. The effects of timber harvest overshadow these minor effects of yew removal to the habitat. The effects from timber harvest activities are analyzed in a separate document.

Human activity and disturbance during yew bark harvest could cause additional effects to animals associated with the stands, if it was collected at a different time than timber harvest activities. If the yew bark was collected at the same time of year as the timber harvest activities, the additional human disturbance effects would be minor. Minor effects would have no discernible effects on populations.

\section{B. Direct and Indirect Effects}

There are no known Threatened, Endangered, or Proposed species that are directly dependent on Pacific yew. There are many that associate with the Pacific yew or the habitat where it grows. Since no Threatened, Endangered, or Proposed species are directly dependent on yew bark there should be minor effects from the loss of 
bark. Many species associate with yew and there could be effects from the loss of the yew tree/shrub and from the human disturbance connected with yew bark harvest.

The following species (taken from Table J-1) associate with Pacific yew or it's habitat and may be affected by the loss of the yew tree/ shrub or the human disturbance connected with yew harvest. Species not discussed below do not occur in areas were there will be yew harvest and will not be effected by yew harvest.

\section{Threatened Species}

\section{Sacramento River winter chinook salmon}

The chinook salmon is found along the Pacific coast from the Ventura River in southern California to Point Hope Alaska. It is also found in northeast Asia, from the Anadyr River south to Hokkaido, Japan.

Juvenile chinook salmon spend about a year in fresh water before smolting and migrating to the Pacific Ocean. Feeding fish remain in the ocean from 3 to 4 years (range, 2-8 years) before they mature and return to their parent stream to spawn. Average egg production by a female is 5,000 (range $2,250-7,750$ ). The eggs hatch in about 2 months, depending on water temperature. The young remain in the gravel 2 to 3 weeks after hatching. Juveniles remain in fresh water from a few days to 3 years.

It is unknown at this time how much of this salmon's habitat occurs in yew habitat. As more detailed information is available for this salmon, yew distribution, and yew quantity, this question will be answered. For the purpose of this document it is assumed that this salmon does occur in yew habitat, and the yew there meets the minimum requirements in the Pacific Yew EIS for harvest of yew bark. Although it appears very unlikely that any yew in this species' area will meet the minimum requirements needed for bark harvest.

This salmon may be affected by the harvest of yew. The impacts would come from activities that would reduce water quality or 
affect spawning areas (soil disturbance and soil erosion would be the main concerns). If yew bark is harvested in this species' area, site-specific environmental analysis will need to include analysis of any activities that will reduce water quality and/or reduce quality of spawning gravels.

Both Federal agencies involved with the Pacific Yew EIS have management plans that require the protection of Threatened, Endangered, and Proposed species. All management plans have Standards and Guides for the protection of streams and riparian areas. The Pacific Yew EIS has mitigation measures prohibiting harvest of yew bark within 75 feet of streams. The protection in these documents will prevent any direct, indirect, or cumulative effects to this salmon. The existing protection should prevent any adverse effects to this salmon. There will be site-specific environmental analysis completed for any timber harvest or yew harvest activities, which will decide on site-specific protection needed for this species.

\section{Snake River sockeye salmon}

Sockeye salmon are native to the Snake River and historically were abundant in several lake systems in Idaho and Oregon. In this century, a variety of factors have led to the demise of all Snake River sockeye salmon except those returning to Redfish Lake in the Stanley Basin of Idaho.

Most of the spawning at Redfish lake is along the lake shore where ground water percolates through the gravel. A single sockeye female may contain as many as 4,000 eggs. The eggs hatch in 6 to 9 weeks, depending on water temperature. The young remain in the gravel for another 2 to 3 weeks. During their fresh water life, juvenile sockeye salmon feed largely on zooplankton. The downstream migration of smolts occurs in the spring. The young remain at sea for 2 to 4 years before returning as adults.

This salmon could be affected by the harvest of yew. The impacts would come from activities that would reduce water quality or affect spawning areas (soil disturbance and soil erosion would be the main concerns). If yew is harvested in this salmon's area, site- 
specific environmental analysis will need to include analysis for any activities that will reduce water quality and/or reduce quality of spawning gravels.

Both Federal agencies involved with the Pacific Yew EIS have management plans that require the protection of Threatened, Endangered, and Proposed species. All management plans have Standards and Guides for the protection of streams and riparian areas. The Pacific Yew EIS has mitigation measures prohibiting harvest of yew bark within 75 feet of streams. The protection in these documents will prevent any direct, indirect, or cumulative effects to this salmon. The existing protection should prevent any adverse effects to this salmon. There will be site-specific environmental analysis completed for any timber harvest or yew harvest activities, which will decide on site-specific protection needed for this species.

\section{Snake River fall chinook salmon}

The chinook salmon is found along the Pacific coast from the Ventura River in southern California to Point Hope Alaska. It is also found in northeast Asia, from the Anadyr River south to Hokkaido, Japan.

Juvenile chinook salmon spend about a year in fresh water before smolting and migrating to the Pacific Ocean. Feeding fish remain in the ocean from 3 to 4 years (range, 2-8 years) before they mature and return to their parent stream to spawn. Fall chinook migrate in August and September and spawn as soon as the spawning grounds are reached, when water temperatures are between $42^{\circ}$ and $58^{\circ} \mathrm{F}$. Average egg production by a female is 5,000 (range 2,250-7,750). The eggs hatch in about 2 months, depending on water temperature. The young remain in the gravel 2 to 3 weeks after hatching. Juveniles remain in fresh water from a few days to 3 years. Usually, juvenile fall chinook feed for a short time and then migrate to the ocean.

This salmon could be affected by the harvest of yew. The impacts would come from activities that would reduce water quality or effect spawning areas (soil disturbance and soil erosion would be 
the main concerns). If yew is harvested in this salmon's area, sitespecific environmental analysis will need to include analysis for any activities that will reduce water quality and/or reduce quality of spawning gravels.

Both Federal agencies involved with the Pacific Yew EIS have management plans that require the protection of Threatened, Endangered, and Proposed species. All management plans have Standards and Guides for the protection of streams and riparian areas. The Pacific Yew EIS has mitigation measures that prohibit harvest of yew bark within 75 feet of streams. The protection in these documents will prevent any direct, indirect, or cumulative effects to this salmon. The existing protection should prevent any adverse effects to this salmon. There will be site-specific environmental analysis completed for any timber harvest or yew harvest activities, which will decide on site-specific protection needed for this species.

\section{Snake River spring/summer chinook salmon}

The chinook salmon is found along the Pacific coast from the Ventura River in southern California to Point Hope Alaska. It is also found in northeast Asia, from the Anadyr River south to Hokkaido, Japan.

Juvenile chinook salmon spend about a year in fresh water before smolting and migrating to the Pacific Ocean. Feeding fish remain in the ocean from 3 to 4 years (range, 2-8 years) before they mature and return to their parent stream to spawn. The principal spawning months are July through September. Average egg production by a female is 5,000 (range 2,250-7,750). The eggs hatch in about 2 months, depending on water temperature. The young remain in the gravel 2 to 3 weeks after hatching. Juveniles remain in fresh water from a few days to 3 years. Most juvenile spring chinook remain in the stream for one year before migrating.

This salmon could be affected by the harvest of yew. The impacts would come from activities that would reduce water quality or effect spawning areas (soil disturbance and soil erosion would be the main concerns). If yew is harvested in this salmon's area, sitespecific environmental analysis will need to include analysis for 
any activities that will reduce water quality and/or reduce quality of spawning gravels.

Both Federal agencies involved with the Pacific Yew EIS have management plans that require the protection of Threatened, Endangered, and Proposed species. All management plans have Standards and Guides for the protection of streams and riparian areas. The Pacific Yew EIS has mitigation measures that prohibit harvest of yew bark within 75 feet of streams. The protection in these documents will not allow any direct, indirect, or cumulative effects to this salmon. The existing protection should prevent any adverse effects to this salmon. There will be site-specific environmental analysis completed for any timber harvest or yew harvest activities, which will decide on site-specific protection needed for this salmon.

\section{Northern Bald Eagle}

This eagle is listed as a threatened species in Oregon and Washington. Eagles usually locate nests in the upper canopy of large old-growth trees, usually within two or three miles of coastal, lake, or river areas (Stalmaster et al. 1985). Night roosts are generally found in coniferous stands with well-developed canopies which provide thermal cover and shelter from wind and rain.

During winter months, bald eagles forage on water courses that support spawning salmon and/or waterfowl. The eagles generally perch in large deciduous and coniferous trees in close proximity to feeding areas. Eagles may gather at dusk, collecting in the open branches of large trees. From there they fly to communal night roosts, which are usually located within a few miles of feeding areas.

Bald eagle habitat on the Pacific coast is protected and managed in accordance with "The Pacific Bald Eagle Recovery Plan" (USDI Fish and Wildlife Service 1986) and the "Working Implementation Plan for Bald Eagle Recovery in Oregon and Washington" (Washington Department of Wildlife 1989). 
This species may roost, nest, and forage in yew habitat. The loss of yew from harvest should not affect this species. The concern for the Northern Bald Eagle would be the human disturbance connected with yew harvest activities. This disturbance could cause nest abandonment which could result in the death of the young birds.

Present protection for the eagle prohibits timber sale units in areas that would disturb eagles. Present protection should prohibit disturbance in areas outside of timber sale units also. Any timber harvest activity that would degrade the site or disturb the eagles has been prohibited near all known nests and roost sites. With the present protection policies there should be no effect to the bald eagle population, from yew harvest. Site-specific environmental analysis will need to ensure that known locations of eagles are avoided for yew harvest activities.

\section{Northern spotted owl}

For more than a decade there has been growing concern and controversy about managing forested lands for the protection of the northern spotted owl. Concern and controversy increased with the June 26, 1990 listing of the northern spotted owl as threatened with extinction under the Endangered Species Act of 1973. Extensive popular and scientific literature is available discussing various aspects of the controversy.

For a complete discussion of the habitat needs and life history of the northern spotted owl, see the "Report of the Advisory Panel on the Spotted Owl" (Dawson et al. 1986), "Final Supplement to the Environmental Impact Statement for an Amendment to the Pacific Northwest Regional Guide" (USDA 1988b), The Interagency Scientific Committee's (ISC) "Conservation Strategy for the Northern Spotted Owl" (Thomas et al. 1990), the US Fish and Wildlife Service's three status reviews (USDI 1987; USDI 1989; Anderson et al. 1990), and the June 26, 1990, final ruling that listed the northern spotted owl as a threatened subspecies (Federal Register 55: 26114).

This species forages, roosts, and nests in yew habitat. The concerns with this species would be: loss of roost habitat and the effects of 
yew harvest on prey species that could affect the owl. The present protection and the proposed action would not allow yew harvest within areas set aside for the spotted owl (within HCA's, the BLM equivalent, and critical habitat). While there may be some owls existing outside these areas that may be affected by yew harvest, there would be no effect on the species.

\section{Grizzly Bear}

As omnivorous, opportunistic feeders, grizzly bears use a variety of habitats. Ninety percent of the grizzly bears' diet is vegetation. Areas used by bears in the spring contain early emergent vegetation. Examples of spring bear range include south-facing avalanche chutes and shrub fields. Big game winter range and anadromous fisheries provide concentrated protein sources for bears in the spring and early summer. Summer and fall habitat components are generally composed of grass/forb and shrub communities. Examples of these include avalanche chutes, harvested units, sidehill parks, and open canopy forest. Winter den habitat is often above 6,000 feet in areas of heavy snowpack. Good denning sites may occur near ridges and upper avalanche chutes. Home ranges as large as 1,004 square miles have been reported (National Wildlife Federation 1987; Almack Pers. comm.).

This species does forage in yew habitat. The concern with yew harvest affecting grizzly bear is the human disturbance connected with yew harvest activities. This species has a recovery plan which limits the amount of disturbance and vegetative change allowed within grizzly bear habitat. If yew is harvested in the grizzlies' area, site-specific environmental analysis will need to include analysis of the level of activity allowed in grizzly bear habitat.

Both Federal agencies involved with the Pacific Yew EIS have management plans that require the protection of Threatened, Endangered, and Proposed species. The proposed action does follow the recovery plan for this species. The protection in these documents will not allow any direct, indirect, or cumulative effects to the grizzly bear. The existing protection should prevent any adverse effects to the grizzly bear. There will be site-specific environmental analysis completed for any timber harvest or yew 
harvest activities which will also take into account site-specific protection needed for this species.

No adverse effects are expected due to the proposed action.

\section{Endangered Species}

\section{American Peregrine Falcon \\ (Falco peregrinus anatum)}

Peregrines are limited to areas which contain suitable nesting ledges. Cliffs and bluffs typically found along river courses and other large bodies of water usually provide habitat for nesting peregrines (Call 1978). Falcons prefer to nest where the concentration of prey, generally smaller birds, is high and where habitat "structural characteristics...may increase prey vulnerability" (Skaggs et al. 1986). In the Pacific Northwest, this generally is within $1 / 4$ to $1 / 2$ mile of riparian, lacustrine, or marine ecosystems.

This species may use prey species that use yew habitat for foraging, and nesting. The concerns with this species are: human disturbance near nest sites during yew harvest activities; and effects of yew harvest (removal of yew fruit, a food source) on prey species.

The harvest of yew will have a minor impact on prey species since aril production is sporadic and usually limited in number. The loss of this forage base for the prey species would have the most impact in areas where yew is a dominant species, but even in these areas there should be no adverse effects to the American Peregrine Falcon due to the limited number of arils and the amount of allowed harvest of yew.

There is a recovery plan for this species. The proposed action follows the recovery plan objectives. Both Federal agencies involved with the Pacific Yew EIS have management plans that require the protection of Threatened, Endangered, and Proposed species. The protection in these documents should not allow any direct, indirect, or cumulative adverse effects to this falcon. There will be site-specific environmental analysis completed for any 
timber harvest or yew harvest activities which will decide on necessary protection needed for this falcon. The site-specific environmental analysis for areas in the Idaho Panhandle National Forest should give specific protection to the following areas, since historic eyries do no have protection under the Endangered Species Act:

1 The Pend Oreille Lake Historic Eyrie;

2 Clark Fork River Canyon Historic Eyrie; and

3 the Clark Fork Delta Hack Site.

No adverse effects are expected due to the proposed action.

\section{Peregrine Falcon (Falco peregrinus)}

This subspecies of falcon is listed due to the similarity in appearance and habitat use to the American Peregrine Falcon. It would receive the same protection as the American Peregrine Falcon and the effects to this subspecies would be the same as for the American Peregrine Falcon.

\section{Northern Bald Eagle}

This eagle is listed as endangered in California, Idaho, and Montana. Eagles usually locate nests in the upper canopy of large old-growth trees, usually within two or three miles of coastal, lake, or river areas (Stalmaster et al. 1985). Night roosts are generally found in coniferous stands with well-developed canopies which provide thermal cover and shelter from wind and rain.

During winter months, bald eagles forage on water courses that support spawning salmon and/or waterfowl. The eagles generally perch in large deciduous and coniferous trees in close proximity to feeding areas. Eagles may gather at dusk, collecting in the open branches of large trees. From there they fly to communal night roosts, which are usually located within a few miles of feeding areas.

This species may roost, nest, and forage in yew habitat. The loss of yew from harvest should not affect this species. The concern for this species would be the human disturbance connected with yew 
harvest activities. This disturbance could cause nest abandonment which could result in the death of the young birds.

Present protection for the eagle prohibits timber sale units in areas that would disturb eagles. Present protection should prohibit disturbance in areas outside of timber sale units also. Any timber harvest activity that would degrade the site or disturb the eagles has been prohibited near all known nests and roost sites. With the present protection policies there should be no effect to the bald eagle population, from yew harvest. Site-specific environmental analysis will need to ensure that known locations of eagles are avoided for yew harvest activities.

\section{Marbled Murrelet}

The marbled murrelet, a member of the alcid family, is a robinsized seabird which congregates to feed primarily in salt water. Murrelets typically feed on small fish and invertebrates within one mile of shore (Marshall 1988). They are found throughout the North Pacific; the American subspecies range from Alaska to wintering grounds as far south as California.

Although marbled murrelets are numbered in the hundreds of thousands in Alaska (Marshall 1988), and up to 3,000 off the coast of Washington (Spiech et al., in press), the numbers dwindle to approximately 1,000 breeding pairs off the coast of Oregon (Nelson et al., in press), and an estimated 1,650 birds in California (Carter and Erickson 1988).

Marbled murrelet nests have been found from southeastern Alaska to northern California in a range of forest structures from stands of wholly old-growth trees to mixed stands containing mature and old-growth trees. Nest sites, characterized by depressions in moss and lichens, have been located on large, lateral branches. Murrelets have been detected as far inland as 43 miles in Washington, 35 miles in Oregon, and 24 miles in California (Nelson 1990; Hamer, Pers. comm.; Paton and Ralph 1988).

This species may nest in yew habitat. The concern with yew harvest affecting marbled murrelets is the human disturbance 
connected with yew harvest activities. If yew is harvested in the murrelet's area, site-specific environmental analysis will need to include analysis of the level of activity allowed in old growth habitat that is known or suspected to contain marbled murrelets.

Both Federal agencies involved with the Pacific Yew EIS have management plans that require the protection of Threatened, Endangered, and Proposed species. The protection in these documents will not allow any direct, indirect, or cumulative effects to this species. The existing protection should prevent any adverse effects to this species. There will be site-specific environmental analysis completed for any timber harvest or yew harvest activities which will also take into account site-specific protection needed for the marbled murrelet.

No adverse effects are expected due to the proposed action.

\section{Columbian white-tailed deer}

This subspecies of white-tailed deer lives, in Oregon and Washington, along the Columbia River from Portland to Astoria, and in the Umpqua Valley near Roseburg, Oregon.

It is unknown if there is any harvestable yew in the range of this species. If there is, then the concerns would be: loss of forage, loss of thermal cover, and human disturbance connected with yew harvest activities. For this document it is assumed that there is harvestable yew within the range of this deer.

This species does forage in yew habitat. The concern with yew harvest affecting this deer is human disturbance connected with yew harvest activities. The two time periods that would have the most human disturbance impacts are during fawning season and winter time. Yew is not harvested during the winter, but surveys could be completed during the winter. Yew is harvested during the spring, so there is the potential for impact during the fawning season. If yew bark is harvested in this deer's area, site-specific environmental analysis will need to include analysis of the level of activities allowed in winter range and fawning areas. 
The loss of forage will not be noticeable. These deer are in the low elevation areas that generally have mild winters so vegetation is available year around. The sprouting of yew from cut trees will create more available forage by lowering the crown height of the yew stand.

The loss of thermal cover will not be noticeable. As mentioned above the winters are generally mild and the amount of yew is small (if there is any available). Specific critical winter ranges will be protected under the site specific environmental analysis.

Both Federal agencies involved with the Pacific Yew EIS have management plans that require the protection of Threatened, Endangered, and Proposed species. The protection in these documents will not allow any direct, indirect, or cumulative effects to this deer. The existing protection should prevent any adverse effects to this species. There will be site-specific environmental analysis completed for any timber harvest or yew harvest activities which will also take into account site-specific protection needed for this species.

No adverse effects are expected due to the proposed action.

\section{Gray Wolf}

Gray wolves utilize many habitat types. The availability of prey seems to be the primary factor in determining suitability of habitat. Primary foods for wolves are ungulate species, such as deer, but they also consume small mammals such as rodents. There have been reports of home ranges as large as 1,197 square miles (Paradiso and Nowak 1982).

This species may forage, rendezvous, and den in yew habitat. The concerns with this species are human disturbance (connected with yew harvest activities) occurring during denning and rendezvous; and effects of yew harvest on prey species (change in prey movement patterns from loss of forage and/or human disturbance).

This species has a recovery plan which limits the amount of disturbance and vegetative change allowed within gray wolf habi- 
tat. If yew bark is harvested in this species' area, site specific environmental analysis will need to include analysis of the level of activities and vegetative manipulation allowed in gray wolf habitat.

Both Federal agencies involved with the Pacific Yew EIS have management plans that require the protection of Threatened, Endangered, and Proposed species. The proposed action does follow the recovery plan for this species. The protection in these documents will not allow any direct, indirect, or cumulative effects to the wolf. The existing protection should prevent any adverse effects to the wolf. There will be site-specific environmental analysis completed for any timber harvest or yew harvest activities which will also take into account site-specific protection needed for the wolf.

\section{Woodland caribou}

The woodland caribou of North America (Rangifer tarandus caribou) is broken down into 2 "ecotypes": mountain and northern, based on the different habitat and behavior patterns of this subspecies. Only the Selkirk population of the mountain caribou is listed under the Endangered Species Act, and exists in extreme northeastern Washington and northern Idaho, within the Selkirk mountains. This population is shared with British Columbia.

Habitat requirements appear to be distinctive with late winter habitats almost exclusively in the upper subalpine fir timber types with deep snows in excess of 20 feet, where their diet consists of arboreal lichens of the genera Alectoria and Bryoria (USDI, Selkirk Mountain Recovery Plan, 1985). Spring brings a elevational shift to lower elevation open areas where early greenup of forbs and grasses is the primary diet. As summer approaches the higher elevation, moist Engelman spruce basins are preferred and utilized through late summer and rut. Early winter snows move the Selkirk mountain caribou to the lower elevation cedar/ hemlock old growth types and the ecotone between the cedar/ hemlock-spruce/fir types that provide snow interception during the time when snows are deep but still fluffy. As soon as these deep snows will support the weight of the caribou, with their large hooves, they again move to higher elevations and the lichen diet. 
This species may forage, and winter in yew habitat. It is unknown if there is any yew of harvestable size in the caribou range. If there is, then the concerns would be: loss of forage, loss of thermal cover, and human disturbance connected with yew harvest activities.

This species may forage in yew habitat. This species has a recovery plan which limits the amount of disturbance and vegetative change allowed within caribou habitat. If yew is harvested in this species' area, site-specific environmental analysis will need to include analysis of the level of activities allowed in caribou habitat.

Both Federal agencies involved with the Pacific Yew EIS have management plans that require the protection of Threatened, Endangered, and Proposed species. The propose action does follow the recovery plan for the caribou. The protection in these documents will not allow any direct, indirect, or cumulative effects to this species. The existing protection should prevent any adverse effects to this species. There will be site-specific environmental analysis completed for any timber harvest or yew harvest activities which will also take into account site-specific protection needed for the caribou.

\section{Conclusions}

The proposed action does not plan to step outside the existing management plans, where they manage Threatened, Endangered, or Proposed Species. By law, the Pacific Yew EIS does not propose any activity that would move a Threatened, Endangered, or Proposed Species any closer to extinction. With the present level of knowledge about species' habitat needs and locations, it is possible to accomplish this level of protection.

Under the present recovery plans and management plans there is no indication that harvesting yew under the proposed action will adversely effect any Threatened, Endangered, or Proposed Species. Each site-specific environmental assessment (whether for timber harvest and yew harvest or just for yew harvest) will look at the effects to Threatened, Endangered, or Proposed species. There is nothing in the proposed action to cause any site-specific environmental assessment to adversely effect any Threatened, Endangered, or Proposed species. 


\section{Table J-1}

The occurrence and status of Federally-listed threatened, endangered and proposed species on National Forests and Bureau of Land Management Districts within the geographic range of the Pacific yew are summarized in Table J-1 on the following pages. Threatened, endangered, and proposed species that occur within the Pacific Yew EIS's area of consideration, but do not occur within Pacific yew habitat, are marked with an *. Species that do not occur within Pacific yew habitat will not be affected by yew harvest, and are not analyzed above.

\section{Definitions}

Endangered: The classification of endangered refers to those species in danger of becoming extinct throughout all or a significant portion of their range.

Threatened: Threatened species are those likely to become endangered in the foreseeable future (50 CFR 240).

Proposed: Those species that have had formal documents published in the Federal Register under the direction of the Endangered Species Act and 50 CFR 402.2, but have not been listed as endangered or threatened at this time.

A list of endangered, threatened, and proposed species, a discussion of Forest Service and BLM responsibilities under the Endangered Species Act, and biological evaluations can be found in most Forest Service offices (USDA Forest Service Manual 2670, USDA Forest Service, 1990a) and Bureau of Land Management State Offices (BLM Manual 6840, 1988). 
Table - 1: Sumary of Threatened, Endengered and Proposed Species

OCCURRENCES OF FEDERAL LISTED AND PROPOSED SPECIES THAT OCCUR IN PACIFIC YEM HABITAT

\section{Federal Threatened}

SPECIES

Lahontan Cutthroat Trout * (oncorhynchus clarki henshavi)

Piute Cutthroat Trout * (Oncorhynchus clarki seleniris)

Foskett Speckled Dace (Rhinichthys osculus spo.)

Warner Sucker (Catoctomus harnerensis)

Aleutian Canodo Goose
(Branto canodensis

(eucopareia)
OCCURRENCE

Documented on BLM Vale and Burns District Documented on USFS Toiyabe Mational Forest Documented on BLM Lakeview District

Documented on 8 lm Lakeview
District

Documented on BLM CoOS BaY District. Suspected on BLM Spokane District. Documented on USFS Siuslaw Mational Forest.
HABITAT

Aquatic: restricted to southern Malheur and Harney Co., Ore.

Aquatic:restricted to silver King Creek a tributary to Carson River.

Aquatic:endemic to Foskett and Dace Springs. Lake Co., Ore.

\section{Aquatic:endemic to Warner}

Basin, Lake Co., Ore.

stops in Pacific Northwest

thile migrating from Alaska to

California. Winters at

wet lands, grasslands, or

cultivated fields, usually near

large, undisturbed bodies of

water.
Sacramento River winter

Chinook Salmon

(Oncorhynchus tshawytscha)
Suspected on USFS Mendocino, Shasta-Trinity, Lassen, and

Plumes National Forests.

\begin{tabular}{lll}
\hline Snake River Fall Chinook & Documented on BLM Coeur & Aquatic: Grande Ronde River \\
Salmon & d'Alene District. Suspected drainage in Ore. \\
(Oncorhynchus tshawytscha) & on BLM Vale District. \\
& Suspected on the USFS \\
& Unatilla and Wallowa-thitman \\
& National Forests.
\end{tabular}

Snake River Spring/Summer Chinook Salmon (Oncorhynchus tshaurtscha)
Documented on BLM Vole and Coeur d'Alene Districts. Documented on the USFS

Unatille and Wallowa-

Whitman Mational Forests.
Aquatic: Grande Ronde River drainage in Ore.
Aquatic: Sacremento River drainage in California

Documented on BLM Solem wet meadows in Willamette District. Suspected on BLM Valley and Coast Range, Ore. Eugene District.

(Sidalcea nelsoniana) District. Suspected on BLM Valley and Coast Range, Ore.

Documented on BLH Burns, Coastal sand dunes and beaches

\begin{tabular}{ll}
\hline Western Snowy Plover & Documented on BLM Burns, \\
(Charadrius alexandrinus & Coos Bay, Lakeview, and Vale \\
nivosus) & Districts. Supected on BLM \\
Spokane District.
\end{tabular}

Bald Eagle
(Oregon and Washington)
(Haliaeetus leucocephalus)




\section{Federal Threatened}

\section{SPECIES}

Northern Spotted OWl

(Strix occidentalis caurina)
OCCURRENCE

Documented on BLM Coos Bay,

Eugene, Lakeview, Medford,

Roseburg, Salem, Spokane,

Ukiah, and Vale Districts.

Documented on USFS Gifford

Pinchot, Mt. Baker-

Snoqualmie, Mt. Hood,

Okanogan, Olympic, Rouge

River, Siskyou, Siuslaw,

Unpqua, Wenatchee,

Willamette, and Winema

National Forests.
Grizzly Bear

(Ursus arctos)
Documented on BLM Spokane, and Coeur d'Alene Districts. Documented on USFS Colville,

Mt. Baker-Snoqualmie,

Okanogan, and Flathead

National Forests. Suspected

on USFS Wenatchee Mational

Forest.
HABITAT

Resident of old growth conifer

forests.

an opportunistic feeder using

a variety of habitats.

Documented on USFS Siuslaw

Restricted to salt-spray meadows

Oregon Silverspot Butterfly Documented on US
(Speyeria zerene hippolyta) National Forest.

Valley Elderberry Longhorn Documented on USFS Six Rivers Elderberry is required for the life Beetle

(Desmocerus californicus National Forest.

cycle. Usually found in riparian

dimorphus)

areas due to elderberry growing there. 
Borax Lake Chub * (Gila boraxobius)

\section{Lost River Sucker .} (Delistes luxatus)
Documented on BLM Burns District.
Aquatic:endemic to Borax Lake, Harney Co., Ore.

\section{Snake River Sockeye Salmon Documented on BLM Vale, and Aquatic: in the Snake River (oncorynchus nerka) Coeur d'Alene Districts. drainage.}

Shortnose Sucker
(Chasmistes brevirostris)

Documented on BLM Lakeview District. Documented on USFS Winema National Forest. Suspected on USFS Fremont National Forest.
Aquatic:Klemath and Lost River systems, Klanath Co., Ore. Also in Calif.
American Peregrine Falcon (Falco peregrinus anatum)
Documented as a resident on BLM Medford, Salem, Vale, and bluffs near riparian, lacustrine, Coeur d'Alene Districts. Documented as a resident on USFS Mt. Hood, Rogue River, Siskiyou, Umpque, Wall lowaWhitman, Willamette, and Gifford Pinchot National Forests. Documented as a resident on USFS Klemath, Six Rivers, Shasta-Trinity, and Mendicino National Forest in Region 5. Documented as a transient on BLM Coos Bay, Burns, Lakeview, Prineville, Roseburg, and Spokane Districts. Documented as a transient on USFS Deschutes, Fremont, Mt. BakerSnoqualmie, Okanogan, Malhuer, and Winema National Forests. Documented on USFS Clearwater, Flathead, Idaho Panhandle, Kootenai, Lolo, and Mez Perce National Forests. Suspected on USFS Colville, Olympic, Umatille, and Wenatchee National Forests.

\section{Peregrine Falcon}

(all species are listed

due to similarity in appearance to American Peregrine Falcon)

(Falco peregrinus spg)
Due to the similarity in appearance between these falcons it is assumed that most observers could not differentiate between, so the known sightings could be for either falcon and the known lacations would be identical for these falcons.

\section{Bald Eaple}

(Calif.., Idaho, and Montana) (Hal iaeetus leucocepholus)

Documented on USFS

Clearwater, Flathead, Idaho

Parhandle, Kootenai, Lolo, and Nez Perce National Forests. Documented on BLM Coeur d'Alene District. see habitat description for American Peregrine Falcon.

See habitat description for

Bald Eagle above. 


\section{Federal Endengered}

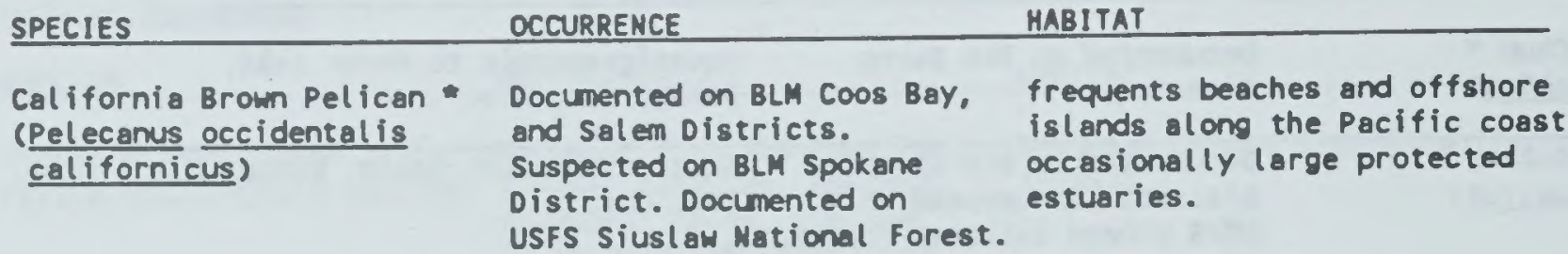

(Brachyramphus marmoratus) and Salem Districts. large, lateral branches of old Documented on USFS Mt. Baker-growth trees; generally within 50 Snoqualmie, Olympic, Siuslaw, miles of the ocean. Siskiyou, Gifford Pinchot, and Six Rivers National Forests. Suspected on USFS Klamath, Mendocino, Wenatchee, and Rouge River Mational Forests.

\begin{tabular}{ll}
\hline Columbia thitetailed Deer & Documented on BLM Roseburg \\
(Odocoileus virginianus & District. Suspected on BLM \\
(eucurus) & Salem District.
\end{tabular}

Gray Wolf

(Canis luous)

Documented on BLM Spokane, and Coeur d'Alene Districts. Suspected on BLM Vale District. Documented on USFS Clearwater, Flathead, Idaho Panhandle, Kootenai, Lolo, and Nez Perce National Forests. Documented on USFS Colville, Fremont, Mt. BakerSnoqualmie, and HallowaWhitman National Forests. Suspected on USFS OKanogan National Forest.

Woodland Caribou
(Rangifer tarandus caribou)
d'Alene District. Docu-

Bradshaw's Lonatium (Lomatium bradshawii)

$\begin{array}{ll}\text { Malheur Wirelettuce } & \text { Documented on BLM Burns } \\ \text { (Stephanomeria malheurensis) District. }\end{array}$
(Stephanomeria malheurensis) District.

\begin{tabular}{ll}
\hline McDonald's Rock-cress * & Documented on BLM Ukiah \\
(Arabis mcdonaldiana) & District. Documented on USFs \\
& Siskiyou and Six Rivers \\
& National Forests.
\end{tabular}

MacFarlane's Four O'Clock suspected on BLM Vale
Oak woodlands and savannahs; riparian areas of the lower Columbia River and Douglas Co., Ore.

utilizes many habitat; prey availability determines suitability of habitat. Documented on BLM Coeur mented on USFS Colville National Forest.

Documented on BLM Eugene District. Suspected on BLM Salem District. wet prairies in willamette valley, Ore.

endemic to single zeolite hill with sagebrush in Harney Co., Ore. requires lichens associated with mature or old growth trees

steep talus slopes with sumy District. Documented on USFS exposure. Hall owa-Whitman National Forests. 
Federal Proposed

SPECIES

Applegate's Milk-vetch OCCURRENCE

Suspected on BLM Lakeview District.
HABITAT

endemic to moist meadows in the Applegate area in Klamath Co., Ore.

Suspected on BLM Salem and coastal salt marsh

Spokane Districts.

Oregon Chub .

Documented on BLM Roseburg

District. Suspected on BLM

Ponds with little or no water

(Oregonichthys (-Hybopsis)

cromeri)

movement.

Salem District. Documented

on USFS Willamette National

Forest. Suspected on USFS

Umpqua National Forest. 


\section{Letter of Clanification to U.S. Fish and Wildlife Service}

Unlted states Forest Departient of service Agriculture
Pacific Mortbmest Reglon
333 B.W. First Avenue

P.O. Box 3623

Portland, OR $97208-3623$

\author{
Reply Io: 1950 \\ Dete: \\ June 18,1993
}

Mr. John Nuse

Blologiet

Fish and Wildilfe service

911 NE 11 th Ave

Portlend, OR

$97232-4181$

Dear Mr. Nuss,

I an writing to clarify our ltuation with consultation on the Pacific Yew EIS. When the BA was written and sent to you, we did not have a preferred

aternative ldentifled, other than knowing that it would not be the preferred aternative Identified in the draft IIS. We, therefore, discusaed a rather broad range of action (anywhere between Alternative B to Alternative D). We have ince ldentified Alternative $B$ a the preferred alternative for the rinal EIS.

We are requesting informal consultation on the adoption of Alternative B of the Pacific Yew IIS. We think that implementation of this alternative will realt in a "may affect, but not likely to adversely affect" situation for the following reasons:

1. Alternative B allow for hervest of yow in timber sale unite and other areas where 1t would otherwise be destroyed. Ilmber sale units are defined in the FEIS a any area within a timber ale which has a slvicultural prescription for a clearcut, shelterwood, or seed tree harvest method. Pacific yow may also be harvested for taxol from other areas where it would otherwise be destroyed by such activities a other timber harvesting, road building or other construction, prescribed fire treatment, or similar activities. Ihere would be no harvest of yow outside of timber sale units, except as described above.

2. NEPA analysis at the project level would be neceseary prior to yew harvest. Consultation, if needed, would also occur at the project level, prior to any yew removal.

3. There should be very fow, if any, ite-specific effecte to threatened and endangered specles byond that caused by the timber ale. If there are adverse effects aseoclated with yow removal, rather than the timber ale 1tself, project NEPA analyale and consulation should reveal them. $\boldsymbol{A}$ new vitigation mesure was added to the FEIS to emphasize eite-pecific conoultation with FWS: Paclfic yew harvect will follow the appropriate seaconal 
reatrictions for the affected listed opecles indicated durlng the profect level (alte-specific) bection 7 formal consultation with OSDI Flah and W1IdIIfe service.

4. Inder Alternative B, yow lo malntalned or replaced on tlober ale units at pre-hervest levels. Where pre-harvest yow densitles are estared to be greater than 50 yow plante per acre, then a minlmus of 50 yow plants par acre

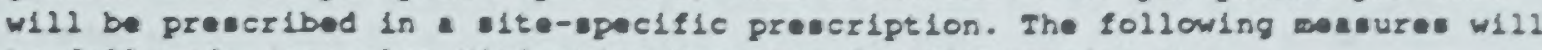
be followed: (see also Mitigation Meavies for Alternative B)

a. Where posible, yow le retalned in the green tree reserve.

b. Barvelet only yow that wete current ut1lization etendarde (curzently yew over 3 Inches in diaseter at the stump, 12 inches above ground).

c. Protect sturop and residual seedlings and saplings as wuch a posible and practlcal frow pot-harvest activitles such a sath pling and burnlng d. Plan logging oyeteas and slash disposal cothoda which favor the survival of reeldual yew plants and stumps.

- Include retention of yow and yow stuape a one of the prescribed lize objectives in burning plans.

L. Leave l1tter and down wood in those patches for seedling establishment. g. If natural regeneration and residual yow do not weet pre-harvest levels, yew 111 be planted as prescrlbed in elte-epeclfic prescription.

h. Yow w111 not be harvested, at a elnleura, within 75 feet lope dietance froc the average hlgh-water level of a perennlal etrear. Where forest plans, resource manageant plane, or other plane or preverlption et wider etreaside buffere, theee greater buffer w111 be adhered to.

5. Onder Alternat1ve B, yow harvest w111 not occur in opotted ow conservation erea. a defined by the RIs, roreut service - Bubltet Conservation Area; BLM - Old-Growth Eophasis Area, Designatled Coneervation Areas, Reserved Palr Arees, Kanaged Palr Areas, Rosldurd gebltat Areas, Protected Babltat Areas, and Protected gabltat Area Buffers as descibed in the BLY draft resource managecent plane.

Please call we 1 there are any further questions or clarifleation needed. I can be reached at (503) 326-7755 by phone or (503) 326-2469 by rax. Thank you for your attention on this.

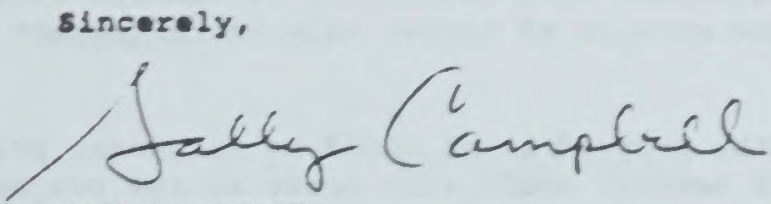

SALIY CAYPBELI

Pacifle Yow IS Ieas Leader

ce: Robert Purent1, THS-Bolse Rusa Peterson, ris-portland тесpar KсMater, ras-Belena Trank Roberts, Is Grant Gunderson, IS Rlek Robert:, Is
Dave Fredrick, Frs-olyapia wayne mite, Fis-sacramento Charles Lobdell, ris-Bolee rent rresidder, BLX razen W1ison, is 


\section{Letter of Clarification to National Marine Fisheries Service}

Ualted states Depertaent of Agriculture rorest service
Pacific Morthwet Rogion
333 S.W. First Avenue

P.O. Box 3623

Portland, OR $97208-3623$
Reply To+ 1950

Date:

June 18,1993

Mr. Merritt Tuttle

Diviaion Chief

National Herine Fleherles Service

911 NE 11th Ave - Room 620

Portland, OR 97232

Dear Mr. Iuttle,

I am writing to clarlfy our aluation with consultation on the paclfic Yow EIS. When the BA was wrltten and sent to you, we did not have a preferred alternative ldentifled, other than knowing that lt would not be the preferred alternative identifled in the draft $\mathbf{E I S}$. We, therefore, discused a rather broad range of action (anywhere between Alternative B to Alternative D). We have Ince ldentifled Alternative $B$ a the preferred alternative for the Final IIS.

we are requesing informal consultation on the adoption of Alternative $B$ of the paciflc Yow EIS. We think that implenentation of this alternative will reault in a "may affect, but not likely to adversely affect" ituation for the following reasone:

1. Alternative B allowe for harvest of yow in timber ale unite and other areas where it would otherwlee be destroyed. Timber sale units are defined in the FEIS a eny area within a timber ale which has a sivicultural prescription for a elearcut, shelterwood, or seed tree harvest wethod. Paclfic yow may 1100 be harvested for texol from other areas where 1t would otherwlse be destroyed by such ectivitles a other timber herventing, road building or other conetruction, a prescribed flre treatment, or imilar activities. There would be no harveat of yew outalde of timber sale unlte, except as described above.

2. NEPA analyols at the project level would be neceseary prlor to yew harvest. Consultation, if needed, would also occur at the project level, prior to any yow removal.

3. There hould be very few, if any, olte-spelfic effects to threatened and endangered pecien beyond that caued by the timber sele. If there are adverse effects ansociated with yow removal, rather than the trmber sale 1tself, project MEPA analyel and consulation hould reveal them. $A$ new mitlgation measure was added to the rEIS to emphasize ste-apecific consultation with FW: Pacifle yew harveat will follow the appropriate ceasonal 
reetriction for the affected lieted epecles indlcated during the project level (alte-pocific) section 7 formal coneultation with oSDI Fieh and Wildilfe service.

4. Onder Alternat 1ve B, yow lo malntalned or replaced on timber sale unlte at pre-harvest levele. Where pre-harvest yow denelties are eotloated to be greater than 50 yow plante per acre, then a minimum of 50 yew plante per acre W11 be preecrlbed in a ite-pocific preocrlption. The following meaures will be followed: (eee aleo Mitlgation Meavure for Alternatlve B)

a. Where posible, yow is retalned in the green tree reeervo.

b. Harveet only yow that meete current ut1l1zation otandarde (currently yew over 3 inchee in diameter at the etump, 12 incheo bove ground).

c. Protect etumpe and reeldual eeedling and eaplinge a much a poesible and practical frow post-harvestactivities weh a elach pling and burning d. Plan logging yotem and lavh dispoel wethode which favor the ourvival of reoldual yew planto and etumpe.

- Include retention of yew and yow etumpe one of the preecribed flre objectiver in burning plane.

f. Leve litter and down wood in thoee petche for eedling evtabliehment. g. If natural regeneration and reoldual yow do not meet pre-harveot levelo, yew w11l be planted a preecribed in elte-peciflc preecriptione.

h. Yew w11l not be harveoted, at a minlmum, within 75 feet lope dietance from the average hlgh-water level of a perennial etream. Where forest plane, revource manegament plane, or other plane or preecriptione eet wider etreameide buffere, theee greater buffero w111 be adhered to.

5. Under Alternative B, yow harvest w11 not occur in epotted owl coneervation areas a defined by the Fis: Foreet service - Habltat Coneervation Areas; BLM - Old-Growth rophale Areve, Deelgnatied Coneorvation Mrea, Reserved Pali Mreav, Maneged Pair Mreee, Reoldual Habitot Mreas, Protected Habitat Areae, and Protected Babltat Area Buffere a decribed In the BLM' draft resource management plane.

Pleaee call we $1 f$ there are any further queetion or clarification needed. I can be raached at (503) 326-7755 by phone or (503) 326-2469 by FAx. Thank you for your attention on this.

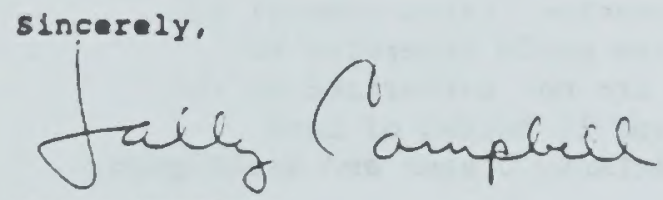

SALLY CAMPBELI

Pacifle Yew IIS Team Lader

cei Michael Tohan, MMS-Portland

Frank Roberta, is

Kent Treoldder, BLM

Grant Gundereon, is

Raren Wileon, IS

Rlck Roberte, is 


\section{Letter of \\ Concurrence \\ from U.S. Fish and \\ Wildlife Service}

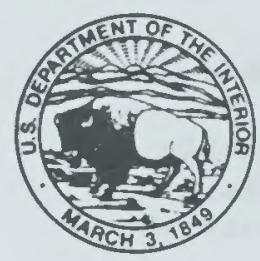

\section{United States Department of the Interior}

FISH AND WILDLIFE SERVICE

911 N. E. 11 th Avenue

Portland, Oregon 97232-4181

AUG 02 1993

Sally J. Campbell

Pacific Yew EIS Team Leader

U.S. Forest Service, Pacific Northwest Region

P.0. Box 3623

Portland, Oregon 97208-3623

Dear Ms. Campbe11:

The Fish and Wildlife Service (Service) has reviewed the Forest Service's

Biological Assessment of the Pacific Yew Harvest Environmental Impact Statement and the additional information provided in your June 18, 1993, letter.

It is our understanding that the proposed action is defined as the selection and implementation of Alternative $B$, as described in the Pacific Yew Environmental Impact Statement (EIS). This alternative limits removal of Pacific yew to timber sale units or areas where yew would otherwise be destroyed. Site-specific yew harvest activities are not authorized by the proposed action. Thirty-three national forests and 12 Bureau of Land Management districts within California, Idaho, Montana, Oregon and Washington, comprise the action area.

The biological assessment identifies the following federally listed species that may be affected by the proposed yew harvest in the action area: bald eagle, marbled murrelet, northern spotted owl, peregrine falcon, Columbian white-tailed deer, gray wolf, and woodland caribou.

Due to the broad geographic scope of the proposed action, site-specific harvest methods and associated impacts to listed species are not identified in the biological assessment or EIS. The Service agrees that individual biological assessments that identify site-specific effects of yew tree harvesting must be prepared by the FS/BLM for each yew harvest action proposed within the action area. Consultation pursuant to section 7 of the Endangered Species Act (Act) would be required for all future timber sales where yew is harvested and the FS/BLM determines the harvest may affect listed species.

As a result of informal consultation with your staff, and in furtherance of section 7(a)(2) of the Act and its implementing regulations, 50 CFR Part 402, we concur with your determination that the proposed action is not likely to 
adversely affect federally listed species. Because the proposed action would not adversely affect 1 isted species, formal consultation with the Service is not required at this time (50 CFR 402.14).

If you have any questions about this matter, please contact the Chief Division of Recovery, at 503-231-6241, or the letterhead address.

Sincerely,

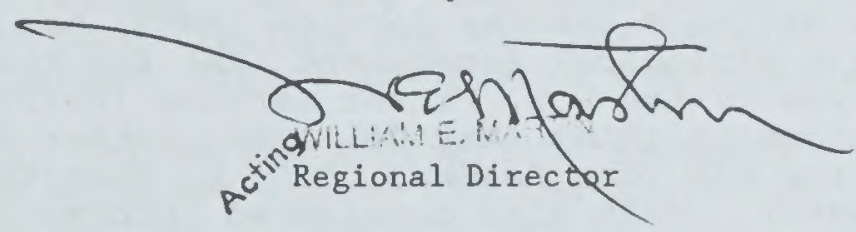




\section{Letter of \\ Concumence from National Marine Fisheries Service}

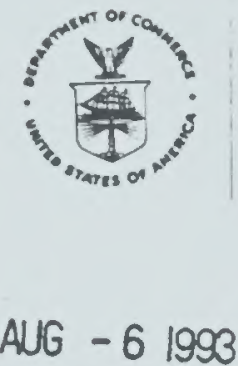

UNITED STATES DEPARTMENT DF CDMMERCE

National Dceanic and Atmospheric Administration NATIONAL MARINE FISHERIES SERVICE Northwest Region 7600 Sand Point Way, N.E. Bin 15700, Bldg. 1 Seattle, Washington 98115-0070

F / NW

Ms. Sally Campbell

Pacific EIS Team Leader

US Forest Service

Pacific Northwest Region

P.O. Box 3623

Portland, Oregon 97208-3623

Re: Pacific Yew Harvest

Dear Ms. Campbell:

National Marine Fisheries Service (NMFS) has reviewed the Pacific Yew Team's Biological Assessment (BA) for the proposed harvest of Pacific yew by the U.S. Forest Service (USFS) and the Bureau of Land Management (BLM) (May 06, 1993, letter from Sally Campbell, Pacific Yew EIS Team Leader, USFS, to Merritt Tuttle, Division Chief, NMFS). NMFS also considered information provided in your June 18, 1993, letter to Merritt Tuttle, NMFS.

The proposed action is defined as the selection and implementation of Alternative $B$, as described in the Pacific Yew Draft Environmental Impact statement (DEIS). This alternative limits the removal of Pacific yew to timber sale units or areas where yew would be otherwise destroyed. No site-specific yew harvest activities are authorized by the proposed action. The action area encompasses 33 national forests and 12 BLM districts within Washington, Oregon, California, and Idaho.

The BA identifies four species of listed Pacific salmon that may be affected by proposed yew tree harvest in the action area: Sacramento River winter chinook salmon, Snake River sockeye salmon, Snake river fall chinook salmon, and snake River spring/summer chinook salmon.

Because of the broad geographic scope of the proposed action, specific harvest methods and associated impacts to listed species are not identified in the BA or DEIS. Specific effects of yew tree harvesting would be addressed in individual environmental impact statements or environmental assessments prepared for each individual timber sale. Consultation pursuant to section 7 of the Endangered Species Act (ESA) would be required for all future timber sales where yew is harvested and the USFS or BLM determines the harvest may affect listed anadromous fish species. 
As a result of informal consultation with your staff, and in furtherance of section 7 (a) (2) of the ESA and its implementing regulations, 50 CFR Part 402 , NMFS concurs with your determination that the proposed action is not likely to adversely affect Snake River sockeye salmon, Snake River spring/summer chinook salmon, Snake River fall chinook salmon, or Sacramento River winter chinook salmon. Because the proposed action would not adversely affect listed anadromous fish species, formal consultation with NMFS is not required at this time (50 CFR 402.14 ).

NMFS concurrence is predicated upon implementation of all mitigation procedures described in the BA and DEIS, and the following additional conditions:

1. Yew harvest would be conducted in accordance with all conditions and restrictions that are developed in future project specific ESA consultations for all yew harvest activities that may affect listed anadromous fish species.

2. Yew harvest will follow the appropriate seasonal restrictions for the affected listed species indicated during project-level section 7 formal consultations.

3. Yew harvest will be performed in accordance with all monitoring procedures defined during project-level section 7 consultations.

4. Conservation measures for listed anadromous fish species that are developed during project-specific consultations in the future may be more restrictive, and shall take precedence, over the general conservation measures described in the programmatic Pacific yew DEIS.

To conclude this informal consultation under the requirements of the ESA (Section $7(a)(2)$ and 50 CFR 402.13) please provide your written confirmation that the conditions listed above are accurate and will be implemented by the USFS and BLM. The USFS and BLM must reinitiate this ESA consultation with NMFS if (1) the conditions described above are not met; (2) new information reveals effects of the action that may affect listed species in a way not previously considered; (3) the action is modified in a way that causes an effect to 1 isted species that was not previously considered, or (4) a new species is listed or critical habitat is designated that may be affected by the action (50 CFR $402.16)$. 
Wildlife and

Biological Assessment

3

If you have any questions, please contact Mike Than (503)

231-2338 or Naga Vera (503) 231-2313.

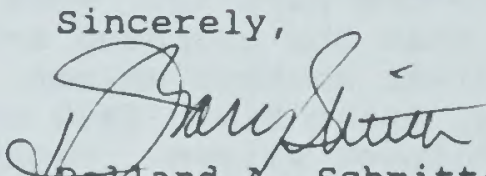

cc: Gordon Haugen - USFS

Rolland A. Schmitten

Regional Director

Pacific Yew FEIS

Appendix J.66 


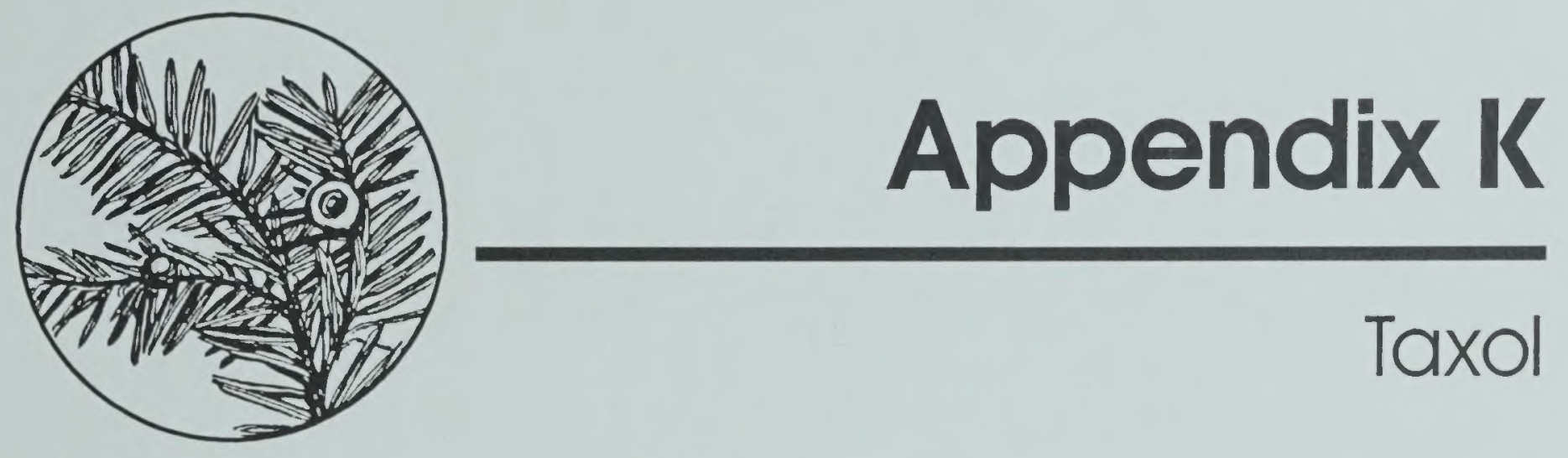




\section{Changes Made Since the Draff EIS}

\section{Appendix K}

Omitted the "National Cancer Institute Clinical Brochure," and the "1991 Annual Report on Taxol to the Food and Drug Administration." (For information regarding clinical and preclinical trials, or the current annual report contact the National Cancer Institute, Division of Cancer Treatment in Bethesda, Maryland.) 


\section{Appendix K}

\section{Taxol}

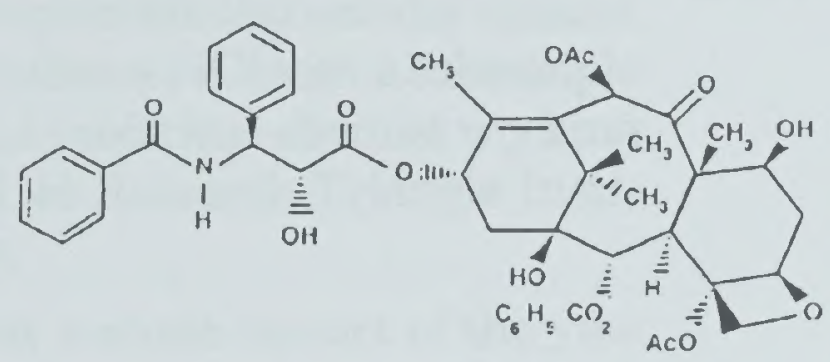

Table of Contents

Chronology of Taxol Development

A National Cancer Institute ( $\mathrm{NCl}$ ) newsletter providing an overview of "Taxol and Related Anticancer Drugs."

A Bristol-Myers Squibb Newsletter providing background information on "The Search for Alternative Sources of Taxol."

The "Request for Applications for Research Project Grants for Biological and Chemical Studies of Taxol," published by the National Cancer Institute in 1990.

Summary of the Food and Drug Administration's new drug application process (includes information on drug laws).

Press releases from Hauser Chemical Research covering 1992 bark collection season and increased taxol production capacity. 

The following is a chronology of the development of taxol as a cancer-fighting drug:

1963: NCI found that yew samples showed activity against $9 \mathrm{~KB}$ cancer-cell tissue culture. NCI sent a subsample to Monroe Wall, Ph.D., a medicinal chemist working under contract to NCI at Research Triangle Institute in North Carolina.

1964: Wall's group found that a crude extract of the yew bark was effective in both the cancer-cell tissue system and against a mouse leukemia. They worked to isolate the primary active principle of taxol.

1966: Wall asked NCI to give the yew material special priority for research. He isolated the active principle and named it taxol.

1969: NCI checked the activity of all parts of Pacific yew. They now knew three things - the structure of taxol, its success in cancer screens, and something about how it worked against cancer.

1971: Wall, with Mansukh Wani (at Research Triangle Institute) and Andrew McPhail (of Duke University), published the structure of the taxol molecule, a complex diterpene with an unusual oxetane ring and an ester side chain.

1974: Taxol began to show results against a recently developed B16 mouse melanoma system. During the 1970s, cytotoxicity tests continued with tumor lines in new animal screens, including human tumor xenografts (tissues grafted from one species to another).

1977: Preclinical work on taxol began. NCI contacted Susan Horowitz (professor of molecular pharmacology at Albert Einstein College of Medicine in the Bronx), working under an NCI Cancer Research Emphasis Grant, to ask her to investigate how taxol worked on cancer cells. With graduate student Peter Schiff, she found that taxol inhibited the replication of human tumor cells. (Specifically, taxol induces "tubulin polymerization" and inhibits disassembly of microtubules, an activity necessary to complete cell division.)

\section{Chronology of Taxol Development}


1978: Taxol showed positive results in human cancer xenografts. Taxol showed activity in three systems, including a human breast cancer xenograft developed in the late 1970s.

1979: Horowitz and Schiff published their findings about taxol's action of freezing microtubules and causing the cell to die.

1980: Toxicology studies began. Scientists looked for a suitable surfactant formulation for administering the insoluble drug.

1982: NCI approved taxol for filing an Investigational New Drug Application (INDA) with the Federal Drug Administration.

1983: Phase I clinical trials began, testing patients who were not responding to other treatments, determining doses and toxicity, and generating data on dose limits of taxol.

1987: NCI contracted for collection of 60,000 (Daly, 1992) pounds of dry Pacific yew bark.

1988: Phase II clinical trials showed 30 percent improvement in patients with unresponsive cases of advanced ovarian cancer.

1989: Trials of taxol progressed for other forms of cancers: breast, cervical, colon, gastric, non-small-cell lung, prostate, head and neck, small-cell lung, and renal. NCI contracted for an additional 60,000 pounds of dry bark.

1990: Phase II trials showed 48 percent tumor shrinkage with metastatic breast cancer patients who had at least one prior chemotherapy regime. (Metastatic refers to cancers which tend to spread from one body part to another.)

1992: Clinical trials were conducted at 20 centers on a number of different cancers, with some experimenting with combinations of chemotherapies.

Food and Drug Administration approved the New Drug Application for taxol from Pacific yew bark for commercial use. 
National Institutes of Health

May 19, 1992

Elaine Blume

(301) 496-6641

\section{Taxol and Related Anticancer Drugs}

Taxol is a plant-derived anticancer drug currently being evaluated in clinical trials supported by the National Cancer Institute (NCI). It was first isolated from the bark of the Pacific yew tree, Taxus brevifolia, which is native to old-growth forests of the Pacific Northwest, but it is also found in bark and needles of related species throughout the world.

Development of taxol has been slow because a large amount of bark (the equivalent of three or more trees) is needed to treat a single patient. Also, the concentration of taxol in Pacific yew bark--still the only acceptable source for trials in humans--is low, making it expensive to extract, and it is not soluble in water, complicating its use in patients.

\section{Clinical Trials}

Scientists first began clinical studies of taxol in 1983, and by 1988 preliminary results suggested that it was active against ovarian cancer. More definitive trials since that time have continued to be_encouraging.

Taxol has been tested in more than 200 patients with recurrent ovarian cancer, which is generally resistant to chemotherapy. The tumors of at least 30 percent of these patients have responded to a significant degree, with some responses lasting more than a year. Early 
studies indicate that taxol could also play an important role in treating several other types of cancer, including advanced breast cancer.

Like other cancer drugs, taxol has unpleasant side effects and occasional severe toxicity, but these adverse effects are generally acceptable relative to the drug's benefits.

\section{Unique Mode of Action}

Taxol has been the focus of great scientific interest because of its unique mode of action as well as because of its potential for treating cancer.

Cells have fibrous skeletons composed of structures known as microtubules that assemble and come apart as the cells progress through their life cycles. Interference with microtubule assembly and disassembly blocks cell division.

Certain anticancer drugs act by inhibiting microtubule assembly. Taxol, in contrast, interferes with cell function and division by promoting assembly and inhibiting disassembly of microtubules, causing the cells to become crowded with bundles of the thread-like structures. Because its mode of action differs from that of other anticancer agents, scientists hope taxol may prove effective in treating cancers that have grown resistant to other drugs.

\section{Increasing Demand}

The encouraging results from taxol clinical trials have increased demand for the drug, both from researchers wanting to perform additional trials and from patients who have few alternative options and would like to take taxol either within or outside of trials. 
This year, NCI officials expect more than 4,000 patients with breast, ovarian, and several other types of cancer to receive taxol in trials, and about 2,000 patients with ovarian cancer to receive the drug on a compassionate basis. However, the potential demand could be much greater, especially if, as anticipated, taxol soon receives approval from the Food and Drug Administration (FDA) to be marketed for use in refractory (treatment-resistant) ovarian cancer.

To meet the demand for taxol and facilitate eventual marketing, NCI needed to work with a company that could produce the drug in quantity. In January 1991, after an open competition, the institute signed a Cooperative Research and Development Agreement (CRADA) with the pharmaceutical manufacturer Bristol-Myers Squibb (BMS). Under the terms of the CRADA, BMS received exclusive access to data from NCI's preclinical studies and clinical trials of taxol. In exchange, the company agreed to supply NCI with the drug for trials and compassionate use, to pursue a New Drug Application with the FDA for permission to market taxol, and to seek alternative sources of the drug.

In order to carry out its obligations under the CRADA, BMS has been working with the Department of Agriculture's Forest Service and the Department of the Interior's Bureau of Land Management in a concerted effort to collect large amounts of Pacific yew bark.

During the 1991 fiscal year, BMS organized the collection of over 825,000 pounds of yew bark from national forest lands in Oregon, Washington, Idaho, and Montana. Taxol extracted from the bark is being delivered to NCI by BMS and will be used in clinical trials. 
However, the Pacific yew is a limited resource located in old-growth forests that serve as a habitat for the endangered spotted owl. For this reason, and because bark collection and taxol extraction are difficult and expensive, NCI and BMS do not consider yew bark to be a viable source of taxol over the long term. NCI has thus been encouraging research directed toward finding alternative and renewable sources of taxol.

\section{Varied Approaches}

Researchers engaged in this effort have been exploring a variety of approaches, including extraction of taxol from yew needles (a renewable resource), genetic manipulation of plants to increase the yield of taxol, propagation of trees, semisynthesis, total chemical synthesis, and plant tissue culture.

NCI has been supporting several of these approaches for some years. The level of support amounted to $\$ 1.5$ million at the beginning the 1991 fiscal year. In July 1990 , the institute issued a Request for Applications for new research grants in this area, and additional grants of $\$ 2.28$ million have since been awarded, bringing total current funding to $\$ 3.78$ million. NCI has also expressed willingness to collaborate with pharmaceutical companies to obtain taxol analogues (related compounds) from sources other than bark.

NCI officials expect that within two to three years sufficient taxol will be available from alternative sources to reduce the pressure for bark collection. However, it may be as long as five years before the need for bark is completely eliminated. 


\section{Synthesis and Semisynthesis}

A number of outstanding chemists have been trying to synthesize taxol, and they have made significant progress. At Stanford University, a researcher supported by NCI and BMS has succeeded in duplicating most of the complex structure that lies at the core of the taxol molecule. He and his colleagues hope to be able to produce the entire molecule by the end of 1992.

Much work will be required before this bench-level synthesis can be scaled up enough to make a significant contribution to taxol supply, and it is not clear whether total chemical synthesis will ever be a practical means of producing the drug for clinical use. However, this approach does offer opportunities for scientists to synthesize structural analogues of taxol for research studies and, potentially, for clinical development.

Partial synthesis of taxol, starting with a complex natural product, is more likely to be commercially feasible. Working along these lines, a chemist at Florida State University in Tallahassee has developed an improved method of semisynthesis, starting with baccatin III, a taxol precursor found in needles of several yew species. This process has been licensed to BMS, which expects to use the method to produce large quantities of taxol within the next year or two.

\section{Alternative Sources}

Meanwhile, researchers at a Forest Service laboratory in Madison, Wis., have been studying methods of extracting taxol from heartwood of the Pacific yew. This approach 
could increase the total yield of taxol from each tree. However, it would still require destruction of trees.

Several different Taxus species might eventually be used to furnish taxol. The compound has been identified in bark and leaves of trees native to India and Europe as well as North America. Plants of the yew family currently being grown in commercial nurseries constitute another potentially important, and renewable, source of taxol.

With support from the NCI and the Department of Agriculture (USDA), and with the help of the University of Mississippi and Ohio State University, the Zelenka Nursery in Grand Haven, Mich., has coordinated the collection of large amounts of needles from ornamental yew plants and has found that this material contains significant amounts of taxol.

Ornamental yew are grown in nurseries for several years before they are sold, and they are trimmed every year. Because these cuttings, which have been treated as waste until now, are readily available, they are a potentially useful source of taxol.

BMS is working with the University of Mississippi on a related project and is helping to fund construction of a pilot natural products production facility to aid in the research.

Building on the concept of -obtaining taxol from cultivated plants, BMS and the Weyerhaeuser lumber company have agreed to cooperate to produce taxol from genetically selected stocks. The goal of the project is to grow large numbers of plants with a high yield of taxol. Weyerhaeuser has agreed to supply BMS with taxol-containing plant material through the end of the decade. Since signing the agreement with BMS, Weyerhaeuser has planted more than four million Taxus seedlings as starters for future production populations. 


\section{Biosynthesis}

Although some experts believe that biosynthesis of taxol by plant tissue is likely to take longer than other approaches to become a practical source of the drug, a number of researchers and companies have been exploring this option. A USDA plant physiologist and her co-workers, for example, have developed and patented a technique for growing cells of yew plants in bioreactors (tissue culture vessels), where they produce taxol and taxol analogues.

Phyton Catalytic, Inc., a plant biotechnology company in Ithaca, N.Y., has an exclusive license from USDA to produce taxol in tissue culture using USDA's method, and they have already done this on a small scale. The company has been working in collaboration with BMS to optimize the process and expects to be able to produce taxol commercially within the next few years.

Working independently, ESCAgenetics Corp. of San Carlos, Calif., announced last June that it, too, had succeeded in producing taxol in plant cell culture.

\section{Taxotere}

At present, one of the most promising alternatives to taxol is Taxotere, a related compound, or analogue, developed by the French pharmaceutical company Rhône-Poulenc. The company's U.S.-based spin-off, Rhône-Poulenc Rorer (RPR), has patents on the drug and permission from the FDA to conduct clinical trials of the agent in humans. 
Taxotere is produced by chemically altering a compound extracted from needles of the European yew. These needles are abundant, easily collected, and renewable, and the yield of Taxotere from needles is greater than that of taxol from yew bark.

The structures of Taxotere and taxol are similar, and the two drugs have similar effects on human cells in culture. Taxotere, like taxol, interferes with disassembly of microtubules, thereby blocking cell division. However, Taxotere is somewhat more watersoluble than taxol, which could be an advantage in formulating and administering the drug.

Taxotere has shown promise in early clinical trials, and NCI has been eager to work with RPR to test the new drug in additional trials. To this end, the two parties have recently signed a CRADA for clinical development of Taxotere.

Under the agreement, NCI and RPR will cooperate in conducting clinical trials of Taxotere in a number of cancers, including ovarian cancer, adult acute leukemia, and pediatric leukemias and solid tumors. Plans call for the new agent to be tested both as a single agent and in combination with other drugs. RPR also will conduct independent studies of Taxotere in several cancers.

\section{Deletion Analogues and Prodrugs}

Both taxol and Taxotere are complex molecules. Scientists would like to find a simpler variant with similar activity that could be easily synthesized in the laboratory. As part of this effort, a number of chemists have been studying "deletion analogues" of taxol-variants of the molecule with small portions missing--to determine which parts of the structure are essential for taxol's antitumor effect. 
Meanwhile, researchers at Virginia Polytechnic Institute in Blacksburg, Va., are focusing on developing water-soluble taxol prodrugs--inactive compounds that could be delivered to the patient more easily than taxol and that would be converted into taxol or related active drugs within the body.

The need to fill the taxol supply gap has generated intense effort on the part of NCI, other government agencies, and researchers and businesses in several countries. This effort appears to have paid off, and taxol, possibly along with related compounds, should become widely available for use in cancer patients within the next few years.

$$
\text { \#\# \# }
$$




\section{News}

\section{THE SEARCH FOR ALTERNATIVE SOURCES OF TAXOL}

\section{BACKGROUND INFORMATION}

Contact: Nancy L. Goldfarb

(212) 546-5107

Bristol-Myers Squibb Company 
According to the National Cancer Institute (NCI), taxol is one of the most important anti-cancer drugs discovered in the past decade. The drug, a natural compound derived from the bark of the Pacific yew tree, has shown promise in treating patients with refractory ovarian cancer, a disease which kills nearly 12,500 women each year. Yew bark is the only source of the drug approved for use in humans at the current time.

To expedite the development of taxol so that this promising drug is widely available to cancer patients, NCI signed a cooperative Research and Development Agreement (CRADA) with Bristol-Myers Squibb Company in January, 1991, after a competitive process involving several pharmaceutical companies. The agreement requires Bristol-Myers Squibb to supply taxol to the NCI for clinical research and to file a New Drug Application for taxol as quickly as possible. Although NCI is still conducting clinical testing on several tumor types, Bristol-Myers Squibb expects to file a taxol new drug application seeking approval to market taxol for refractory ovarian cancer sometime in 1992.

At the same time, Bristol-Myers Squibb Company is aggressively pursuing alternative methods of producing taxol to decrease its dependence on Pacific yew bark. The company recognizes that the Pacific yew tree is a precious and finite resource, and does not consider it a viable source for long-term production of taxol. 


\section{ALTERNATIVE SOURCES}

To find alternative sources of the drug, the company is conducting research in its own laboratories and supporting multiple research programs around the world. Already many advances have been made in finding ways to relieve the reliance on yew bark. Bristol-Myers squibb firmly believes it will not be necessary to make a choice between the future of the Pacific yew and human lives because of its aggressive efforts in pursuing simultaneous searches for alternative sources. Within two years, sources other than bark will begin to be utilized for taxol production on a commercial scale; within three years, reliance on bark will decrease substantially; and within five years, the need for bark should cease completely.

\section{ALTERNATIVE SOURCES AGREEMENTS}

As of March, 1992, Bristol-Myers Squibb has entered into over a dozen agreements with various companies, researchers and academic institutions, and has committed millions of dollars to the research and development of alternative sources of taxol. It also continues to negotiate with other companies and universities on collaborative efforts to find alternative sources.

Some of the most promising research programs include:

Extracting taxol from renewable sources, such as twigs and needles of various taxus species. Called biomass, these sources can be collected without damaging the plant; 


\title{
ALTERNATIVE SOURCES
}

\author{
Semi-synthesis, which chemically converts a natural \\ material similar to taxol -- for example, baccatin \\ III found in biomass -- into taxol; \\ plant cell culture, in which taxol would be \\ produced in the laboratory from cells of yew \\ tissues, including roots and leaves; and \\ Total synthesis, which chemically duplicates the \\ taxol molecule. Researchers attempting to produce \\ a synthetic taxol thus far have been unable to \\ duplicate the entire taxol molecule because of its \\ complexity.
}

\section{RESEARCH PROGRAMS}

Following are specific programs supported by Bristol-Myers squibb in its comprehensive search for alternative sources.

\section{CULTIVATED YEW BIOMASS}

Taxol has been found in other Taxus species around the world. However, varying amounts of taxol found in these plants and the difficulties associated with handling and storing the biomass may make them more impractical to harvest than yew bark. One strategy to address these problems is commercial yew plantations. 


\section{ALTERNATIVE SOURCES}

\section{Weyerhaeuser Company}

Bristol-Myers Squibb signed a three-year research agreement with Weyerhaeuser Company in August, 1991, to investigate the large-scale cultivation of varieties of Taxus to help meet the need for taxol. A second agreement between the companies provides for Weyerhaeuser to supply Bristol-Myers Squibb with biomass material containing taxol through the end of the decade.

Weyerhaeuser annually grows about 280 million yew seedlings in its nurseries and has been involved in yew and related taxol research for more than four years. The goal of the program is to grow large numbers of promising taxol-containing yew trees over the next decade.

Weyerhaeuser has planted more than four million Taxus seedlings since the agreement with Bristol-Myers Squibb was signed, and currently has over 20,000 yew trees in research trials. Once the seedlings have rooted, they will be planted in the ground and allowed to grow. As early as late 1994, the trees will be harvested and used for biomass to support taxol production. During 1992, Weyerhaeuser expects to plant five million rooted cuttings at several western nurseries. 


\section{ALTERNATIVE SOURCES}

\section{University of Mississippi}

Bristol-Myers Squibb has signed a $\$ 2.45 \mathrm{million}$ research and development agreement with the University of Mississippi to investigate using raw materials from ornamental shrubs as an alternative source for taxol.

Scientists at the University's Research Institute of Pharmaceutical Sciences have devised a strategy for extracting taxol out of needles clipped from ornamental yews during the normal pruning process. The grant from Bristol-Myers Squibb will enable the research team to refine its process and work toward producing large quantities of taxol economically.

Bristol-Myers Squibb also is providing the University of Mississippi with $\$ 500,000$ toward construction of a pilot natural products production facility to aid in the research.

\section{SEMI-SYNTHESIS}

\section{Florida State University}

Researchers are aggressively trying to build a synthetic taxol molecule which would lessen the burden on the Pacific yew tree because it allows taxol to be produced from related compounds in other plants. Through a five-year, $\$ 1.4$ million grant, Bristol-Myers Squibb is supporting research at Florida state University to synthesize taxol chemically. 


\section{ALTERNATIVE SOURCES}

Florida state already has licensed a semi-synthetic process. Researchers have focused on piecing together the highly complex taxol molecule in the laboratory. The taxol molecule has two parts; the main, which has not been duplicated, and a side chain that has been synthesized. An efficient laboratory-scale method has been devised for attaching the side chain to the main part of the molecule. The main part is a naturally-occuring taxol precursor, which can be isolated from the needles of some yew species. The process is being perfected in the laboratory and must be scaled up before wide-scale production is possible.

Bristol-Myers Squibb is also in the final stages of negotiations with a company with a history of extracting compounds from natural products. Under the agreement, the company would collect renewable biomass from species of Taxus in Europe and Asia and extract 10-deacetyl-baccatin III. Through the semi-synthetic process licensed from Florida State University, the material would be converted into taxol. Deliveries would begin in 1992; Bristol-Myers Squibb expects to produce large quantities of taxol through this method within a few years.

\section{PLANT CELL CULTURE}

\section{Phyton Catalytic. Inc.}

Bristol-Myers Squibb has established a collaborative research and development partnership with Phyton Catalytic, Inc., to develop a plant cell tissue culture process for the production of taxol. 


\section{ALTERNATIVE SOURCES}

Phyton Catalytic, an Ithaca, N.Y., plant biotechnology company, was the first commercial organization to produce taxol in a tissue culture system. It has an exclusive license from the U.S. Department of Agriculture to produce taxol in a tissue culture system. Although substantial progress has been made with this approach, it will take several years to scale up the process and produce large amounts of taxol.

Bristol-Myers Squibb is also working with Hauser Chemical Research on developing and scaling up the process for commercializing many of the above alternative sources.

\section{TOTAL SYNTHESIS}

\section{Ohio State and Stanford Universities}

The complexity of taxol's chemical structure has prevented researchers from totally synthesizing the drug. Bristol-Myers Squibb is supporting research efforts at Ohio State University and Stanford University to find economical ways to synthesize taxol.

A professor of chemistry at ohio state embarked on a two-year, $\$ 360,000$ research program in August, 1991. He and his research team are attempting to assemble the framework of the taxol molecule to create synthetic taxol. Although initial progress has been promising, the final stages of the project are still not imminent. Once total synthesis is accomplished in a laboratory, the next question is whether it could be scaled-up to produce large quantities of taxol. 


\section{ALTERNATIVE SOURCES}

\section{Analogs, Prodrugs, etc.}

In addition to alternative sources research, Bristol-Myers Squibb is working to improve the taxol drug and search for better taxol derivatives. Bristol-Myers Squibb is funding efforts into chemical research involving taxol at the University of Kansas where researchers are studying water soluble derivatives of taxol, and at Virginia Polytechnics Institute. At Virginia Tech, researchers are investigating several compounds similar to taxol that could be used in future development of the drug. The work is being partially supported by a $\$ 260,600$ grant over three years from Bristol-Myers Squibb.

Researchers are attempting to prepare water-soluble, chemical derivatives of taxol also known as prodrugs, which would have the same capabilities of the parent drug and improved physical properties. Once introduced in the body, the prodrug would convert back into taxol. This process can circumvent problems due to taxol's insolubility.

Virginia Tech also is working on a process to convert Cephalomannine, a compound similar to taxol, into taxol. Cephalomannine also is found in the yew bark. The process would allow more of the natural material now harvested to be used in taxol production. 


\section{ALTERNATIVE SOURCES}

Related research for the NCI includes investigating how taxol interacts with cells to gain a better understanding of its cancer-fighting qualities, and creating taxol analogs, compounds that are chemically related but with a small variation from the parent drug.

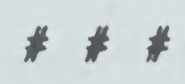


July 27,1990

REQUEST FOR APPLICATIONS for Research Project (R01) Grants

$90-\mathrm{CA}-16$

BIOLOGICAL AND CHEMICAL STUDIES OF TAXOL

NATIONAL CANCER INSTITUTE

APPLICATION RECEIPT DATE: October 24, 1990

LETTER OF INTENT RECEIPT DATE: September 17, 1990

\section{A. INTRODUCTION}

The Division of Cancer Treatment (DCT) of the National Cancer Institute (NCI) invites grant applications from interested investigators for chemical and/or biological studies on taxol ultimately leading either to ways to increase production of this drug or to define further its biological properties for use in improved drug design or in enhanced clinical utility.

Grants are awarded to non-profit and for-profit organizations and institutions, governments and their agencies, and occasionally to individuals. The Request for Application's (RFA) is the type of grant solicitation used when it is desired to encourage investigator-initiated research projects in areas of special importance to the National Cancer Program. Applicants funded under the RFA are supported through the customary National Institutes of Health (NIH) grant-in-aid, in accordance with Public Health Service (PHS) policies applicable to research project grants. However, the RFA solicitation represents a single solicitation, with specific deadlines for receipt of applications. All applications received in response to the RFA will be reviewed by the same NCI initial review group.

The present RFA announcement is for a solicitation in FY 1990 with a specified deadline (October 24, 1990) for receipt of applications. Applications should be prepared and submitted in accordance with the aims and requirements described in the following sections:

* This program is described in the Catalog of Federal Domestic Assistance number 13.395. Cancer Treatment Research. Awards will be made under the authority of the Public Health Service Act, Sections 301 , Public Law $78-410$, as amended, 42 U.S.C. 241 , as amended by Public Law 99-158, 42 U.S.C. and 285(a). This program is not subject to the intergovernmental review requirements of Executive Order 12372 or Health Systems Agency review. 
B. BACKGROUND INFORMATION

C. RESEARCH GOALS AND SCOPE

D. MECHANISM OF SUPPORT

E. ELIGIBILITY

F. REVIEW PROCEDURES AND CRITERIA

G. METHOD OF APPLYING

H. LETTER OF INTENT

I. INQUIRIES

\section{B. BACKGROUND -INFORMATION}

Taxol is an antitumor drug isolated from the Western Yew, Taxus brevifolia, and other Taxus species which has shown excellent confirmed activity against refractory human ovarian cancer and preliminary activity at other sites; it is one of the most promising new drugs in many years. It has a wholly novel mechanism of action, binding to microtubules and stabilizing them against depolymerization. Investigations of the chemistry, biology, biochemistry, and pharmacology of taxol have been limited and many aspects of drug action and of drug production in the source plants, Taxus species, are not well understood.

\section{RESEARCH GOALS AND SCOPE}

The intention of this RFA is to encourage investigators to propose ideas which will increase our knowledge of the drug's properties and which are likely in the long term to contribute to large scale drug supply and to maximally effective usage of taxol in the clinical setting. The following are undeveloped or underdeveloped areas of interest which merit particular attention: (1) biosynthesis and its regulation in Taxus sp.; (2) plant tissue culture to produce taxol and related compounds; (3) agronomics and plant genetics of taxol to enhance production; (4) evaluation of genetic engineering methods to transfer genes involved in taxol biosythesis to fast growing plants; (5) identification of the specific taxol binding site on microtubules and of the amino acid sequences involved, leading to high resolution definition of the binding site and eventually to molecular mimics with simpler structures; (6) frequency, mechanisms, and circumvention of resistance; (7) studies of in vitro combinations of taxol with other cytotoxic agents; (8) metabolism of taxol in human tissue; (9) measurements and consequences of tissue distribution of taxol; and $(10)$ in vivo evaluation of combination therapy using taxol in preclinical models. These areas are not meant to be restrictive and investigator initiated proposals in all areas of taxol research relevant to the goals of this RFA such as total chemical synthesis are encouraged. Either single or multidisciplinary approaches may be proposed as appropriate to the topic area (see also section I, INQUIRIES) . 
The NCI is able to supply limited amounts of taxol for these investigations (up to $100 \mathrm{mg}$. per award). Investigators needing substantial amounts of taxol for proposed studies should contact the Program Director before preparing an application (see section I, INQUIRIES).

Studies which use taxol as a reagent to isolate microtubules or to study microtubule or cycloskeletal function without therapeutic intent will not be considered responsive to this RFA.

D. MECHANISM OF SUPPORT

This RFA will use the National Institutes of Health (NIH) grant-in-aid. Responsibility for the planning, direction, and execution of the proposed project will be solely that of the applicant. Except as otherwise stated in this RFA, awards will be administered under PHS grants policy as stated in the Public Health Service Grants Policy statement, DHHS Publication No. (OASH) $82-50,000$, revised January 1,1987 .

This RFA is a one-time solicitation. Generally, future unsolicited competing renewal applications will compete with all investigator initiated applications and be reviewed by the Division of Research Grants (DRG). However, should the NCI determine that there is a sufficient continuing program need, NCI may announce a request for renewal applications. Only recipients of awards under this RFA will be eligible to apply.

Approximately $\$ 1,000,000$ in total costs per year for five years will be committed to fund applications which are submitted specifically in response to this RFA. It is anticipated that five to eight awards will be made. This funding level is dependent on the receipt of a sufficient number of applications of high scientific merit. Program balance among various areas of taxol/Taxus research will be an important funding consideration. The total project period for applications submitted in response to the present RFA should not exceed five years. Foreign grants are limited to a three year project period. The earliest feasible start date for the initial awards will be July $1,1991$. Although this program is provided for in the financial plans of the National Cancer Institute (NCI), the award of grants pursuant to this RFA is also contingent upon the availability of funds for this purpose. 
E. ELIGIBILITY.REQUIREMENTS

Domestic and foreign non-profit and for-profit institutions are eligible to apply. Governments and their agencies are also eligible.

F. REVIEW PROCEDURES AND CRITERIA

\section{REVIEW PROCEDURE}

Upon receipt, applications will be reviewed intially by the Division of Research Grants (DRG) for completeness. Incomplete applications will be returned to the applicant without further consideration. Evaluation for responsiveness to the RFA is an NCI program staff function. Applications will be judged to determine how well they meet the goals and objectives of the program as described in the RFA. Applications judged non-responsive will be returned by the NCI, but may be submitted as investigator-initiated research grants at the next receipt date. Questions concerning the relevance of proposed research to the RFA should be directed to program staff as described in the INQUIRIES section.

In cases where the number of applications is large compared to the number of awards to be made, the NCI may conduct a preliminary scientific peer review to eliminate those applications which are clearly not competitive. The NCI will remove from competition those applications judged to be noncompetitive for award and notify the applicant and institutional business official.

Those applications judged to be both competitive and responsive will be further evaluated according to the review criteria stated below for scientific and technical merit by an appropriate peer review group convened by the Division of Bxtramural Activities, NCI. The second level of review by the National Cancer Advisory Board considers the special needs of the Institute and the priorities of the National Cancer Plan.

\section{REVIEW CRITERIA}

The factors considered in evaluating the scientific merit of each response to this RFA will be:

1. The degree of importance of the research to one of the following:

a. understanding and/or enhancement of taxol production; 
b. mechanism of activity of taxol as an antitumor agent; and

c. potential enhancement of clinical utility of taxol.

2. The originality of the research plan from a scientific and technical viewpoint.

3. Adequacy, thoroughness, and completeness of the scientific plan.

4. Experience, training and time commitment of the Principal Investigator and staff.

5. Adequacy and availability of laboratory space and equipment required.

6. Clearly demonstrated access to all materials (i.e., chemicals, reagents, biological samples, human tissues, etc.) as are needed for the research.

The review group will critically examine the submitted budget and will recommend an appropriate budget and period of support for each approved application.

G. METHOD OF APPLYING

The most recent revision of the regular research grant application form PHS 398, (Revised 10/88) must be used in applying for these grants. These forms are available at most institutional business offices; from the office of Grants Inquiries, Division of Research Grants, National Institutes of Health, Room 449, Westwood Building, 5333 Westbard Avenue, Bethesda, Maryland 20892; or from the NCI Program Director named below.

The RFA label available in the October 1988 revision of Application Form PHS 398 must be affixed to the bottom of the face page. Failure to use this label could result in delayed processing of your application such that it may not reach the review committee in time for review. In addition, the RFA number and title should be typed on line 2 of the face page of the application form.

Submit a signed, typewritten original of the application, including the checklist, and four (4) signed, exact photocopies, in one package to the address below. The photocopies must be clear and single sided. 
DIVISION OF RESEARCH GRANTS

National Institutes of Health

Westwood Building, Room 240

5333 Westbard Avenue

Bethesda, Maryland 20892

At time of submission, send two (2) additional copies of the application to:

REFERRAL OFFICER

Division of Extramural Activities

National Cancer Institute

Room 838, Westwood Building

5333 Westbard Avenue

Bethesda, Maryland 20892

Applications must be received by October 24,1990 . If an application is received after that date, it will be returned. If the application submitted in response to this RFA is substantially similar to a research grant application already submitted to the NIH for review, but has not yet been reviewed, the applicant will be asked to withdraw either the pending application or the new one. Simultaneous submission of identical applications will not be allowed, nor will essentially identical applications be reviewed by different review committees. Therefore, an application cannot be submitted in response to this RFA which is essentially identical to one that has already been reviewed. This does not preclude the submission of substantial revisions of applications already reviewed, but such applications must include an introduction addressing the previous critique.

\section{H. LETTER OF INTENT}

Prospective applicants are asked to submit by September 17, 1990 a letter of intent that includes a descriptive title of the proposed research, the name and address of the principal investigator, the names of other key personnel, the participating institutions, the number and title of the RFA in response to which the application is being submitted. Since taxol is in very limited supply, for planning purposes, the NCI requests the applicant to indicate the amount of drug that will be required to support the proposed studies.

Although a letter of intent is not required, is not binding, and does not enter into the review of subsequent applications, the information which it contains is extremely helpful in planning for the review of applications. It allows NCI staff to estimate the potential review workload and to avoid possible conflict of interest in the review. 
The letter of intent should be sent to:

BY US POSTAL

Dr. Matthew Suffness

Program Director

Grants and Contracts Operations Branch

Division of Cancer Treatment

National Cancer Institute

Executive Plaza North, Suite 832

Bethesda, MD 20892

Telephone: (301) 496-8783

FAX: (301) 496-8333

BY DIRECT DELIVERY

Dr. Matthew Suffness

Program Director

Grants and Contracts Operations Branch

Division of Cancer Treatment

National Cancer Institute

Executive Plaza North, Suite 832

6130 Executive Boulevard

Rockville, MD 20852

Telephone: (301) 496-8783

FAX: (301) 496-8333

I. INQUIRIES

Written or telephone inquiries concerning the objectives and scope of this RFA or inquiries about whether or not specific proposed research would be responsive are encouraged and should be directed to Dr. Matthew Suffness at the above address. The Program Director welcomes the opportunity to clarify any issues or questions from potential applicants. 


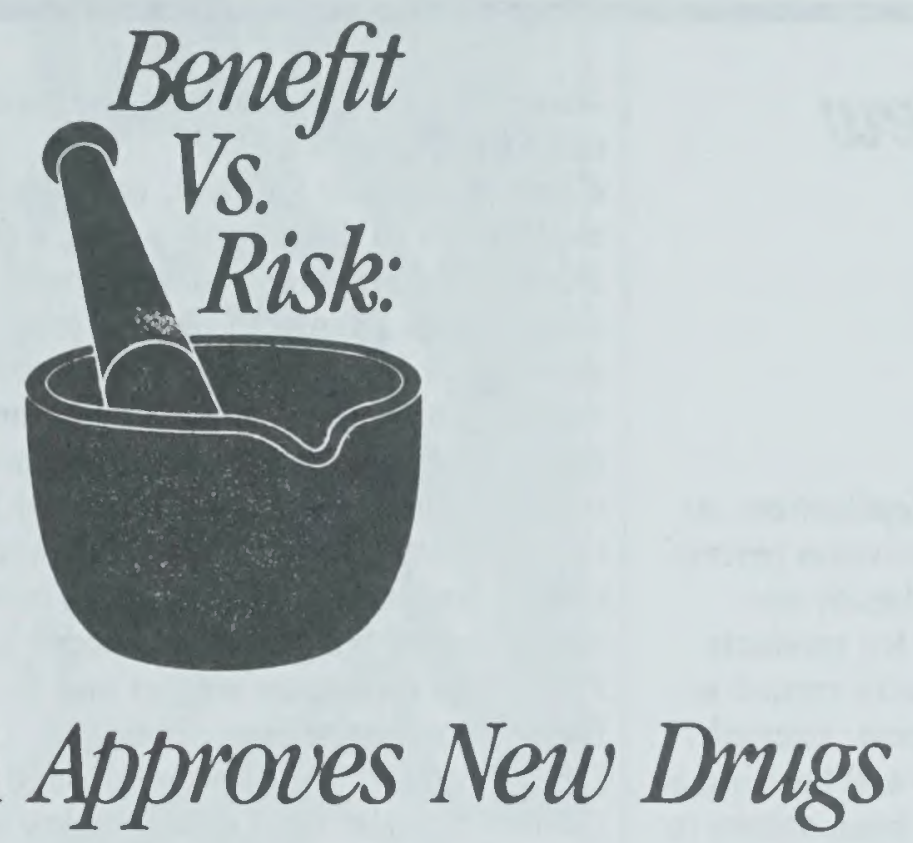

How FDA Approves New Drugs

b. Dixie Farley

$\mathrm{U}$ nder current law. all new drugs need proof that they are effective. as well as safe. before they can be approved for marketing. But it's important to realize that no drug is absolutely safe. There is always some risk of an adverse reaction. It's when the benefits outweigh the risks that FDA considers a drug safe enough to approve.

In fact, it was only 25 years ago that U.S. drug law first embraced the idea of risk vs. benefit that is now the key to new drug approval. Providing evidence of safety before marketing was first required by the Federal Food. Drug. and Cosmetic Act in 1938, but not until the Drug Amendments of 1962 did firms also have to show a drug's effectiveness before marketing. Before any drug gets on the market today. FDA decidesas quickly as a thorough evaluation allows-whether the studies submitted by the drug's sponsor (usually the manufacturer) show it to be safe and effecrive for its intended use. Here's what goes into those decisions.

"Take AZT, for example." says Rober Temple, M.D. . director of FDA's Office of Drug Research and Review. (AZT stands for azidothymidine, the former name of the only approved AIDS drug. now known as zidovudine and marketed as Retrovir.) "An early look at a clinical study with the drug showed there were 19 deaths in patients taking a placebo lan inactive substance], but only one death in those on AZT. Unfortunately, AZT can cause serious adverse effects. Moreover, the drug is not a cure. The disease eventually progresses, despite treatment. We might not have approved the drug if we didn't also know that AZT was effective, that it prolongs life. As it was, an excellent study showed this."

Zidovudine was approved in March 1987 in a record 107 days. "No important new drug in recent memory has ever been acted upon so quickly," FDA Commissioner Frank E. Young. M.D.. Ph.D., has said. But no corners were cut. Indeed, FDA expended an estimated eight staff years at a cost of $\$ 600,000$ on zidovudine's evaluation. That the review was so rapid was

Every document on every shelf in this picture is part of a single new drug application-240 volumes in all. Looking up data in the application's medical section, which is so extensive it's housed in a storeroom rather than in the reviewer's office, is Dr. Alexander Fleming of FDA's division of metabolism and endocrine drug products. due largely to the fact that FDA was involved with the drug every step along the way from the start of basic research. More than 4,000 patients received zidovudine during the course of its investigation. Thus. FDA reviewers were thoroughly familiar with zidovudine when its new drug application (NDA) was submitted. The drug approval process " "at its best." Dr. Young calls that review. "But. no matter what we do." he says. "we want the public to know and understand that miracles don't happen overnight. that studies take years not months. and that patients are best served by rigorous testing and careful review."

\section{PROMISING EXPERIMENTAL DRUGS}

In May 1987. FDA published a regulation to allow broader use of promising experimental drugs such as zidovudine so that desperately ill and dying patients can receive the benefits of those drugs years earlier than was possible before. Promising is the key word in this broadened use of unapproved drugs. FDA can't allow drugs to be used haphazardly. "It's a disservice." says FDA medical officer Alexander Fleming. M.D. . "to let even a dying patient use an unproven drug unless qualified physicians believe it has some chance of helping. That only raises false expectations and might cause needless suffering or hasten death. A 'try anything' approach prevents physicians from quickly learning whether a drug works, and that's a disservice to others similarly ill who could be helped by an effective drug." In other words. FDA requires that experimental drugs. too, satisfy a certain benefit-to-risk ratio.

So, FDA reviewers scrutinize massive amounts of information in NDAs to evaluate the effectiveness and safety of new drugs. A drug is first reviewed, however, when a sponsor submits an investigational new drug application (IND) to FDA before tests with people begin. Within 30 days. FDA must let the sponsor know whether, in its judgment, the proposed test is sufficiently safe. If so, the IND is considered to be "in effect" and the clinical study may proceed; if not, FDA may place the study on hold until the sponsor makes needed changes.

Sponsors are encouraged to meet with FDA before the final phase of human tests, which are the large-scale controlled clinical trials. At this conference, FDA gives advice about the design of the sponsor's study plan to ensure that the trials will 


\section{A Drug Review Glossary}

Abbreviated New Drug Application, or ANDA: A simplified submission permitted for a duplicate of an already approved drug. ANDAs are for products with the same or very closely related active ingredients, dosage form, strength, administration route, use, and labeling as a product that has already been shown to be safe and effective. An ANDA includes all the information on chemistry and manufacturing controls found in a new drug application (NDA), but does not have to include data from studies in animals and humans. It must, however. contain evidence that the duplicate drug is bioequivalent (see "Bioequivalence") to the previously approved drug.

Action Letter: An official communication from FDA to an NDA sponsor that informs of a decision by the agency. An approval letter allows commercial marketing of the product. An approvable letter lists minor issues to be resolved before approval can be given. A not approvable letter describes important deficiencies that preclude approval unless corrected.

Advisory Committee: A panel of outside experts convened periodically to advise FDA on safety and efficacy issues about drugs and other FDA-regulated products. FDA isn't bound to take committee recommendations, but usually does.

Amendment to an NDA $\varepsilon^{2}$ ubmitted to change or add information to a not yet approved NDA or a supplement.

Bioavailability: Rate and extent to which a drug is absorbed or is otherwise available to the treatment site in the body. Bioequivalence: Scientific basis on which generic and brand-name drugs are compared. To be considered bioequivalent, the bioavailability of two products must not differ significantly when the two products are given in studies at the same dosage under similar conditions. Some drugs, however, are intended to have a different absorption rate. FDA may consider a product bioequivalent to a second product with a different rate of absorption if the difference is noted in the labeling and doesn't affect the drug's safety or effectiveness or change the drug's effects in any medically significant way.

Clinical Studies: Clinical, or human, studies aim to distinguish a drug's effect from other influences-for example, a spontaneous change in disease progression or in the effect of a placebo (an inactive substance that looks like the test drug). Such studies conducted in this country must be under an approved IND (see "Investigational New Drug Application"'), under the guidance of an institutional review board, and in accord with FDA rules on human studies and informed consent of participants.

Drug Product: The finished dosage form (tablet, capsule, etc.) that contains a

drug substance, generally, but not necessarily, in association with other active or inactive ingredients.

Drug Substance: The active ingredient intended to diagnose, treat, cure, or prevent disease or affect the structure or function of the body, excluding other inactive substances used in the drug product.

Effectiveness: The desired measure of a drug's influence on a disease condition.

Effectiveness must be proven by substantial evidence consisting of adequate and well-controlled investigations, including human studies by qualified experts, that prove the drug will have the effect claimed in its labeling

Investigational New Drug Application, or IND: An application that a drug sponsor must submit to FDA before beginning tests of a new drug on humans. The IND contains the plan for the study and is supposed to give a complete picture of the drug, including its structural formula. animal test results, and manufacturing information.

New Drug: A drug first investigated or proposed for marketing after 1938 (when the Federal Food, Drug, and Cosmetic Act was passed)-that is, the drug was not generally recognized as safe and effective before that date.

New Drug Application, or NDA: An application requesting FDA approval to market a new drug for human use in interstate commerce. The application must contain, among other things, data from clinical studies needed for FDA review from specific technical viewpoints, including chemistry, pharmacology, medical, biopharmaceutics, statistics, andfor anti-infectives-microbiology.

Pharmacology: The science that deals with the effect of drugs on living organisms.
Post-Marketing Surveillance: FDA's ongoing safety monitoring of marketed drugs.

Pre-Clinical Studies: Studies that test a drug on animals and other nonhuman test systems. They must comply with FDA's good laboratory practices. Data about a drug's activities and effects in animals help establish boundaries for safe use of the drug in subsequent human testing (clinical studies). Also, because animals have a much shorter life span than humans, valuable information can be gained about a drug's possible toxic effects over an animal's life cycle and on offspring.

Raw Data: Researcher's records of patients. such as patient charts. hospital records. X-rays. and attending physician's notes. They may or may not accompany an NDA. but must be kept in the researcher's file. FDA may request their submission.

Review Clock: Time frame of 180 days allowed FDA to review NDAs. The "clock" starts on the date the NDA is received and stops the date a final action (see "Action Letters" entry) is taken. FDA may extend the time if significant changes are made to a pending NDA. From the time an NDA is submitted to when it's approved usually is more than 180 days. for any number of reasonsnotably, time-consuming amendments or a shortage of trained reviewers.

Safety: No drug is completely safe or without the potential for side effects. Before a drug may be approved for marketing. the law requires the submission of results of tests adequate to show the drug is safe under the conditions of use in the proposed labeling. Thus, "safety" is determined case by case and reflects the drug's risk-vs.-benefit relationship.

Safety Update Reports: Reports that an NDA sponsor must submit to FDA about any new safety information that may affect the draft labeling statements about contraindications, warnings, precautions. and adverse reactions. Safety update reports are required four months after the application is submitted, after the applicant receives an approvable letter, and at other times upon FDA request.

Supplement: A marketing application submitted for changes in a product that already has an approved NDA. FDA must approve all important NDA changes (in packaging or ingredients, for instance) to ensure the conditions originally set for the product are not adversely affected. 


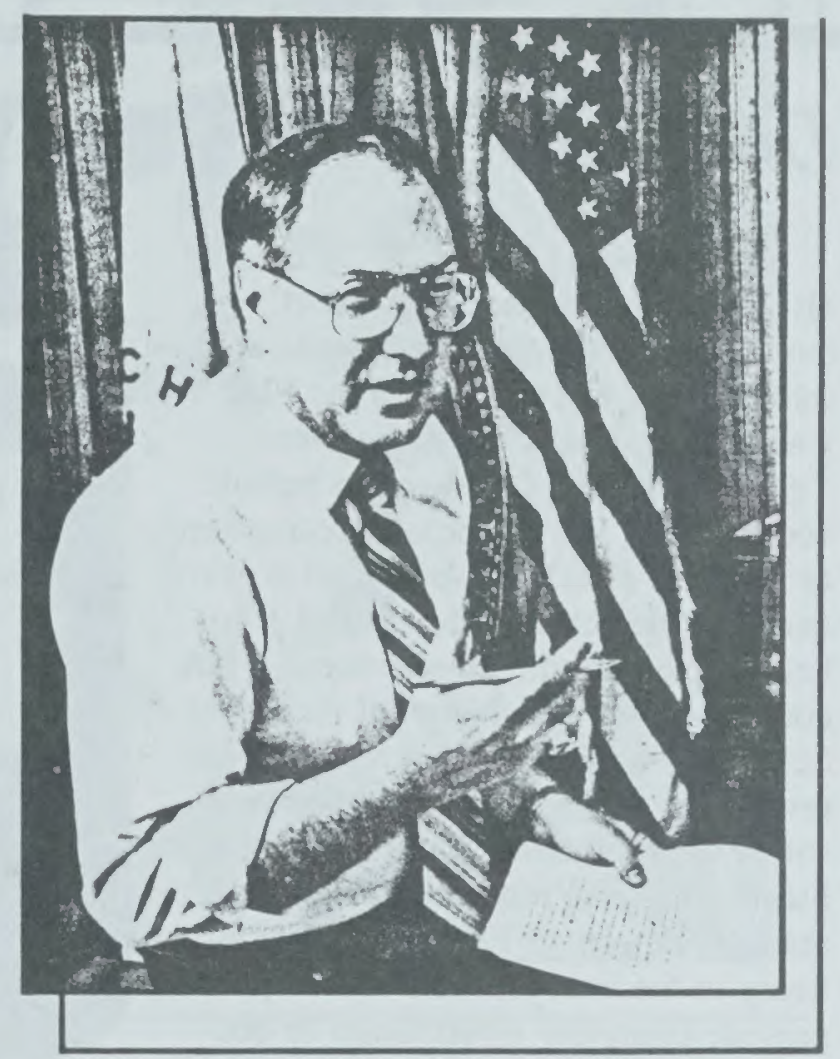

\section{Dr. Frank Young}

\section{(Continued from page 25)}

be acceptable. As FDA's Temple puts it: "We have the experience of finding and eliminating flaws in the plan that we know will give us trouble later on in the NDA review. We don 't want people to carry out a large study that has no chance of being considered adequate and well-controlled "

\section{REVIEW TIME}

On the date FDA receives an NDA. a "review clock" is started: by law. FDA has 180 days to review the application and either approve or reject it. The span from " day 1" to " day of approval " is almost always longer than 180 days. however. both because the initial review takes longer than that and because it is usually necessary to carry out more than one review to resolve issues raised by the information initially submitted. Average approval time. in fact. is more like two years.

"So very often." says the drug center's Deputy Director Gerald Meyer, "we discover that we need more information. Sometimes. an applicant has it and can give it to us quickly. If not. a new study may need to be done and the data submitted. That stretches out the time before approval. " But an application that doesn't have to be amended or resubmitted generally takes far less time to review, says Meyer- " an average of 10 to 18 months less time. " in fact. Of the 926 NDAs approved from 1980 to 1986. 192 "got it right the first time" and. so. averaged just $13 \frac{1}{2}$ months. In 1987, in addition to the record 107-day approval time for zidovudine, the cholesterol-lowering drug lovastatin was approved in only nine months.

\section{A REVIEWER'S DAY}

"If reviewers were doing nothing else, they could probably review an NDA in an outer limit of three months, maybe two." says Meyer. But that's not FDA reality. he is quick to point out. On many a day, a reviewer might be working with four NDAs, each consisting of numerous volumes of data, 12 equally voluminous applications for experimental drugs, and almost as many supplements to approved NDAs. Further, only about 60 percent of a reviewer's time is actually spent reviewing. Meyer says. The rest goes to attending hearings. answering inquiries, developing guidelines, purging trade secrets from documents requested under the Freedom of Information Act, and resolving such problems with drugs on the market as adverse reactions and faulty advertising.

Why is an NDA so lengthy? Because the documentation required is supposed to tell the drug's whole story. including: what happened during the clinical tests: how the drug is constituted-its components. composition, and toxicology: how it behaves in the body: and how it's manufactured, processed and packaged. especially the quality controls. FDA also requires samples of the drug and its labels.

Full reports of a drug's studies must be submitted because they are the basis of FDA's evaluation of safety and effectiveness. The controlled clinical trials are especially important because they involve the greatest number of patients. By providing for the appropriate comparisons to judge the drug's effectiveness and by revealing less common (even rare) side effects and adverse reactions, they help to clarify the drug's benefit-to-risk relationship. The final human studies also generate irformation that will be in the drug's professional labeling, the guidance approved by FDA on how to use the drug. This is the package insen that accompanies a drug in all shipments to physicians and pharmacies.

\section{PRIORITIES}

The order in which applications are looked at is determined with the aid of a classification system. (See accompanying article.) As FDA resources are limited, the idea is to give priority to drugs with the greatest potential benefit. For example, AIDS drugs receive the highest priority, followed by drugs that offer a significant medical advance over existing therapies for any other disease.

Which of FDA's seven review divisions gets an ND 


\section{The Evolution of U.S. Drug Law}

FDA acts as public health protector by ensuring that all drugs on the market are safe and effective. Authority to do this comes from the 1938 Federal Food, Drug, and Cosmetic Act, a law that has undergone many changes over the years. just as it changed earlier drug regulation. Some major milestones in the evolution of U.S. drug law are:

- Food and Drugs Act of 1906: This first drug law required only that drugs meet official standards of strength and purity. The burden of proof was on FDA to show that a drug's labeling was false and fraudulent before it could be taken off the market.

- Federal Food, Drug, and Cosmetic Act (1938): A bill was introduced into the Senate in 1933 to completely revise the 1906 drug law-widely recognized then as being obsolete. But Congressional action was stalled. It took a tragedy in which 107 people died from a poisonous ingredient in "Elixir Sulfanilamide" to prompt passage of revised legislation that, for the first time. required a manufacturer to prove the safety of a drug before it could be marketed. Among other provisions, the law also eliminated the Sherley Amendment requirement to prove intent to defraud in drug misbranding cases, provided for tolerances for unavoidable poisonous substances, authorized factory inspections. and added the remedy of court injunction to previous remedies of seizure and prosecution.

\section{- Durham-Humphrey Amendment} (195I): Until this law, there was no requirement that any drug be labeled for sale by prescription only. The amendment defined prescription drugs as those unsafe for self-medication and which should therefore be used only under a doctor's supervision.

- Drug Amendments of 1962: News reports about the role of FDA medical officer Frances O. Kelsey, M.D. . in keeping the drug thalidomide off the U.S. market aroused public interest in drug regulation. Thalidomide had been associated with the birth of thousands of malformed babies in Western Europe. In October 1962. Congress passed these amendments to tighten control over drugs. Before marketing a drug. firms now had to prove not only safety. but also effectiveness for the product's intended use. The requirement was applied retroactively to 1938, when the FDC Act was passed. (Pre-1938 drugs were "grandfathered" - allowed to be sold because they were generally recognized as safe and effective-provided no evidence to the contrary developed.) To help implement the amendments. FDA contracted with the National Academy of Sciences/National Research Council to review the efficacy of drugs approved solely on the basis of safety since 1938: Firms were also required to send adverse reaction reports to FDA, and drug advertising in medical journals was required to provide complete information to doctors-the risks as well as the benefits.

- Orphan Drug Act (1983): "Orphans" are drugs and other products for treating rare diseases. They may offer little or no profit to the manufacturer, but may benefit people with the rare diseases. To foster orphan product development. this law allows drug companies to take tax deductions for about three-quarters of the cost of their clinical studies. Firms also are given exclusive marketing rights for seven years for any orphan products that are approved.

\section{- Drug Price Competition and Patent} Term Restoration Act of 1984: This law expands the number of drugs suitable for an abbreviated new drug application. or ANDA. ANDAs make it less costly and time-consuming for generics. which are often sold at lower prices than brandname drugs, to reach the market. "Patent Term Restoration" refers to the 17 years of legal protection given a firm for each drug patent. Some of that time allowance is used while the drug goes through the approval process. so this law allows restoration of up to five years of lost patent time.

Though not involving changes in law. the following changes in FDA's drug regulations are noteworthy:

- Revision of New Drug Application Regulations (1985): These changes provide for safety reports after an application for a new drug is submitted. more focused and better organized data. use of summaries and tables for easier review, earlier problem solving, and allowance of approval on the basis of foreign studies alone. It also strengthens the

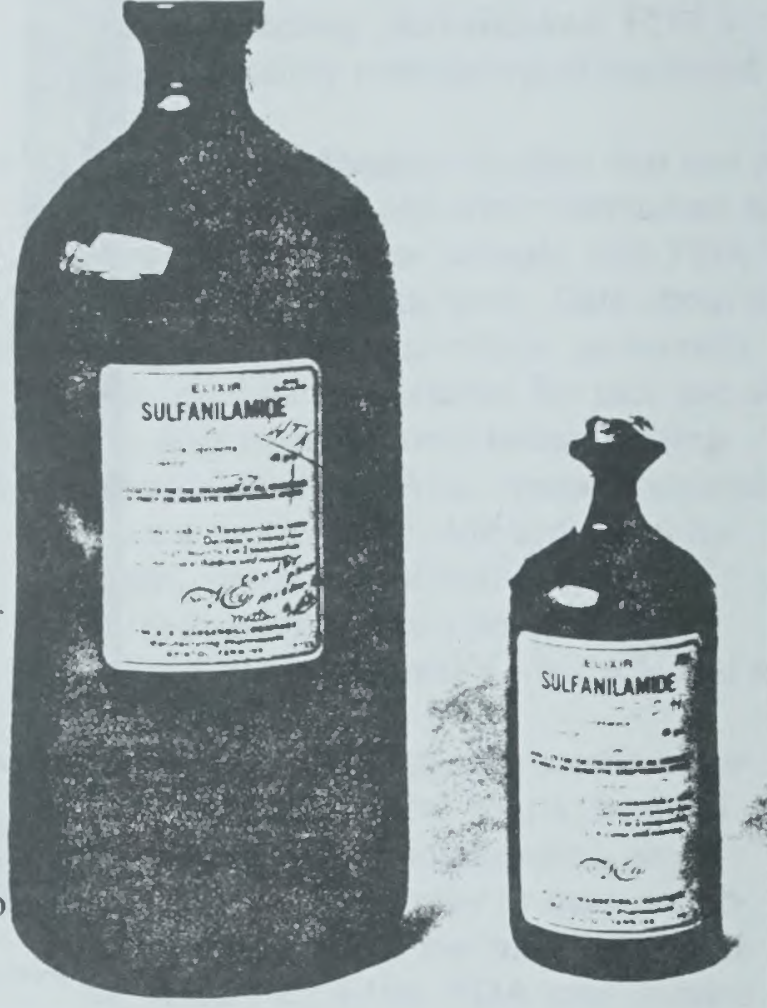

The "Elixir Sulfanilamide" tragedy of 1937 ensured enactment the following year of the Federal Food, Drug, and Cosmetic Act. More than 100 people died from using the untested, poisonous new drug formulation, but FDA had legal authority to bring only a trivial charge of misbranding against the manufacturer. The product was labeled an "elixir," which implied it was an alcohol solution; actually, it was a diethylene glycol solution. If the term "solution" had been used instead, no charge of breaking the law could have been made.

monitoring of adverse reactions from marketed drugs.

- Revision of Investigational New Drug Application Regulations (1987): Encourages problem-solving meetings with FDA, requires deadlines in safety reports, and increases sponsor control over initial human test design so long as subjects face no unreasonable. significant risks.

- Treatment Use of Investigational New Drugs (1987): Patients with serious or immediately life-threatening diseases such as AIDS may now get treatment with experimental drugs that show reasonable evidence of potential benefit. provided no satisfactory approved therapy exists. This applies only to drug. already being studied in controlled clinical trials. Also. the drugs cannot expose patients to unreasonable risk. 


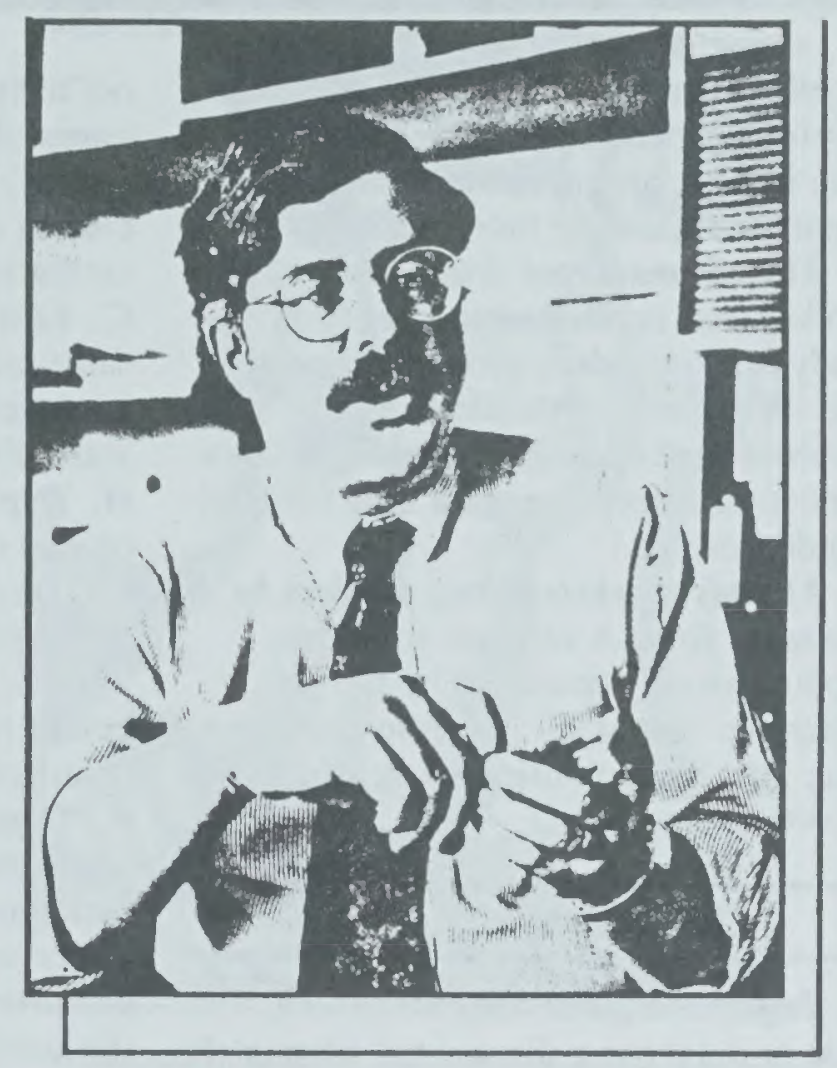

\section{Dr. Robert Temple}

(Continued from page 27)

pends on the drug. Ulcer therapies, for example, go to the division of gastrointestinal and coagulation drug products;

contraceptives go to the division of metabolism and endocrine drug products; and so on.

Each NDA comes in with a summary, usually less than 200 pages. Reviewers may spend several days reading through this and making notes to themselves, such as where to probe for further information and where the drug is likely to cause problems. Then, going through the studies one by one, reviewers ask such questions as:

- What is the study's design?

- Does it demonstrate what it's supposed to?

- Are the results of the studies reasonably consistent?

If the data are from a foreign country, FDA needs to know:

- Can FDA validate the data by an inspection or other means?

- Does the information apply to the American population and medical practice here? Medical practices, drug needs, and drug regulation vary from country to country, so drugs are often introduced in different countries at different times.

\section{THE REVIEW TEAM}

The members of the FDA review team simultaneously apply their special technical expertise to the review of an NDA:

- Chemists focus on how the drug is put together, whether the manufacturing controls and packaging are adequate to ensure the stability of the product, and whether the proposed labeling accurately reflects the effects of the drug.

- Pharmacologists evaluate the effects of the drug on laboratory animals in short-term and long-term studies.

- Physicians evaluate the results of the clinical tests-including the drug's adverse as well as therapeutic effects.

- Other staff evaluate the rate and extent to which the drug's active ingredient is made available to the body and the way it is distributed, metabolized and eliminated. They determine whether the evidence supports the labeling for the recommended dosing regimen. "The object is to give the patient no more drug than is absolutely necessary," says FDA's Meyer.
- Statisticians evaluate the designs for each controlled study, the validity of statistical analyses, and the conclusions of safety and effectiveness based on the study data.

- Microbiologists evaluate the data on anti-infectives (antibiotics, antivirals and antifungals). These drugs differ from others in that they're intended to affect the workings of microbes instead of patients. Reviewers need to know how the drug acts on these microorganisms, which ones it affects, any resistance to the drug, and clinical laboratory methods needed to evaluate the drug's effectiveness. Microbiologists also are concerned with determining whether injectable drugs can be made free of harmful organisms.

When an important new drug is about to be approved, a "Summary Basis for Approval"' is written, laying out FDA's basis for deciding the drug is safe and effective. (Time may be saved if the sponsor drafts the summary for FDA's editing.) Each reviewer edits, or writes, the portion within his or her purview-chemistry, pharmacology, and so forth.

\section{CONTACT WITH SPONSORS}

Anytime during an NDA review, FDA may contact the sponsor or the investigators to discuss problems concerning the data. Indeed, FDA staff may visit the sites of some of the studies to compare results provided in the NDA with the physicians: patient records. If there are major deficiencies with any part of the NDA, substantially more work by the sponsor may be needed.

FDA frequently asks one of its 17 . standing advisory committees on drugs and biologics (see p. 32) for advice. This is especially true when an approval decision is a "close call."

In the final analysis, FDA's decision whether to approve a new drug for marketing boils down to two questions:

- Do the results provide substantial evidence of effectiveness? This may be easy to figure out in a study with a drug to treat high blood pressure - if the drug works, the blood pressure goes down. But other studies, such as those testing a drug to treat depression, are more complicated. 


\section{Review Priorities}

FDA classifies investigational new drug applications (INDs) and new drug applications (NDAs) to assign review priority on the basis of the drug's chemical type and potential benefit:

\section{CHEMICAL TYPE}

1. New molecular entity, or NME: An active ingredient that has never been marketed in this country. (Example: lovastatin, a drug approved in August 1987 to lower high blood cholesterol.) 2. New derivative: A chemical derived from an active ingredient already marketed (a "parent" drug). (Example: haloperidol decanoate, an injectable antipsychotic drug used to treat patients receiving prolonged treatment with injected tranquilizer drugs.)

3. New formulation: A new dosage form or new formulation of an active ingredient already on the market. (Example: estradiol as a controlled-release form of estrogen hormone administered via a skin patch.)

4. New combination: A drug that contains two or more compounds, the combination of which has not been marketed together in a product. (Example: human insulin isophane suspension/regular human insulin, an injectable semi-synthetic agent for regulating blood sugar.)

5. Already marketed drug product: A product that duplicates another firm's already marketed drug product: same active ingredient, formulation, or combination. (Example: another seller's version of meprobamate, a drug for treating depression.)

6. Already marketed drug product by the same firm: A new use for a drug product already marketed by the firm. (Example: minoxidil, a cardiovascular drug now being considered as a hair growth promoter.)

\section{TREATMENT POTENTIAL}

A. Important gain: May effectively treat or diagnose a disease not adequately treated or diagnosed by any marketed drug. Or. may improve treatment because it's more effective or safer. (Example: the cholesterol-lowering drug lovastatin.)

B. Modest gain: Offers a modest, but real, advantage over other marketed drugs-for example, greater patient convenience, elimination of an annoying but not dangerous adverse reaction, fewer required doses, or usefulness for special groups, such as for patients allergic to current drugs. (Example: norfloxacin, an antibacterial.)

C. Little or no gain: Essentially the same medical importance and use as a marketed drug. (Example: ketoprofen, an anti-inflammatory drug.)

H. Orphan drug candidate: Assigned orphan (see. "Orphan Product" in glossary) status for purposes within FDA. (Example: clofazimine, a drug to treat leprosy, would have been in this class before it became " $\mathrm{V}$." a designated orphan drug.)

V. Designated orphan drug: A drug for which the sponsor received orphan designation under the Orphan Drug Act. Such a sponsor is eligible for tax credits and exclusive marketing rights for the drug. (Example: clofazimine.)

Thus, a drug that is a new molecular entity and that represents an important therapeutic gain - such as lovastatin-is designated $\mathrm{I}-\mathrm{A}$ and receives the highest priority review, except for AIDS drugs. All drugs to treat AIDS (acquired immune deficiency syndrome) have been given top priority in a special class. " 1 AA."

\section{ASpecial System for OTC Drugs}

FDA has always applied the same standards to nonprescription drugs as it does to prescription ones whenever proposed over-the-counter (OTC) products meet the criteria for "new drugs." (See "New Drug” in glossary.) In 1966. FDA contracted for a review of the effectiveness of all new drugs approved solely on the basis of their safety since passage of the 1938 Federal Food. Drug. and Cosmetic Act. Special attention soon became focused on OTC drugs: Of the 512 OTC drug products evaluated. 75 percent lacked substantial evidence of effectiveness.

That was when FDA decided it was time to tackle a broader review of OTC drugs-no small job. considering that more than 300,000 products were on the market. Those products, however, involved only about 700 active ingredients. It didn't take long for FDA planners to decide on a strategy: Classify the drugs by treatment category (antacids, laxatives, and so on) and evaluate the ingredients. So, rather than review thousands of, say, individual antacid products.
FDA evaluated the far fewer active ingredients found in them-for example. aluminum hydroxide and magnesium carbonate.

That review, under FDA's division of OTC drug evaluation, is actually a threephase process of producing a final regulation (called a monograph) to establish standards for each product-treatment category.

- The first phase. conducted from 1972 to 1981 . was a review by panels of outside advisors who determined whether ingredients could be generally recognized as safe and effective for self-use. FDA published the reports in the Fecleral Register.

- The second phase-still continuingis FDA's review of the panels findings on the ingredients. In these reviews. FDA takes into account public comments and any new data. The conclusions are published as a proposed rule (or tentative final monograph).

- After considering any new information and objections. FDA publishes the final regulation, or monograph. Final rules have been published for 18 of the 81 product categories.

An OTC drug product doesn't need specific approval before marketing so long as it meets its category's standards.

Sometimes an approved prescription drug is deemed safe enough for self-use and is switched to OTC status. One-half percent hydrocortisone skin cream for temporary relief of minor skin irritation is an example.

A number of ingredients were taken off the market as a result of the advisory panels' OTC drug review. Among them were:

- Camphorated oil, a liniment often accidentally ingested with frequently toxic results.

- Hexachlorophene, once common in deodorant soaps. but now available only by prescription for special antimicrobial purposes because it may damage the central nervous system.

- Tribromsalan, removed from drugs and cosmetics because it was found to make skin extra sensitive to light.

- Zirconium. still safe in most forms of antiperspirants, but removed from aerosols because of concern it could cause lung nodules. 


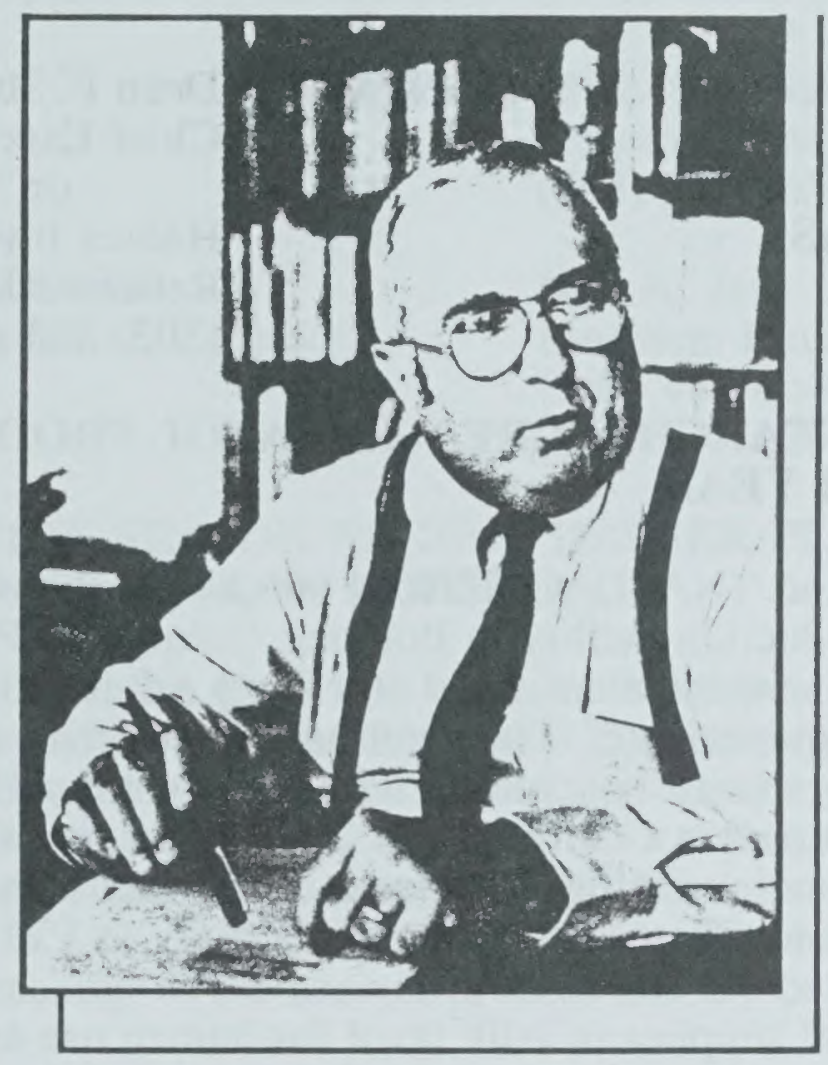

Gerald Meyer

(Continued from page 29)

- Do the results show the product is săfe under the conditions of use in the proposed labeling? Reviewers note whether the adverse reactions show any disturbing pattern of occurrence. They "tease" out, so to speak, whether certain symptomssuch as headache or constipation-were caused by the drug or whether they occurred independently.

To be sure approval decisions reflect the most recent safety data. FDA requires safety updates four months after the NDA is submitted, again after it sends the firm an "approvable letter," and at other times as appropriate-before an advisory committee meeting, for instance. Updates must report new adverse reactions and important changes in the frequency or severity of effects that are known. Thus, new data suggesting that an adverse effect occurs more often than previously thought might change a "precaution" to a "warning" in the labeling.

\section{FINAL ACTIONS}

When FDA staff finish their evaluation, additional review is given by upper management. Final actions on nearly half of all NDAs are decided at the division level. The rest are approved or disapproved at the next management level of the drug center.

FDA then writes the applicant to say either that the drug is approved for marketing, is approvable provided minor changes are made, or is not approvable because of major problems. In the last case, the applicant can then amend or withdraw the NDA or ask for a hearing. Once its NDA is approved, a drug is on the market as soon as the firm gets its production and distribution systems going. FDA approves about 75 percent of all the NDAs submitted.

Most prescription and over-the-counter (OTC) drugs that were on the market before the Federal Food, Drug, and Cosmetic Act was passed in 1938 are "grandfathered." That means they are allowed on the market without the stringent proof of safety and effectiveness required of later drugs. Thus,
FDA has not reviewed every single drug sold in the United States.

As new challenges arise, FDA drug review will no doubt continue to evolve. A vital part of that evolution, says Commissioner Young, is strengthening FDA's science base. A drug approval process "in which we can have confidence," he says, "requires scientific excellence as the basis for difficult regulatory decisions. ... Recruitment is in full swing to build a corps of expert researcher-reviewers to improve our drug review program." Toward that end, FDA's staff of medical officers has increased in number by about 20 percent since 1985.

\section{BIOTECHNOLOGY DRUGS}

Further, FDA has approved several genetically engineered drugs, developed through the new science of biotechnology. Because reviewers work closely with sponsors and investigators during the drug development and testing stages, FDA has been able to review even such high-technology drugs in a timely fashion. Human insulin was approved first, in 1982. Since then, FDA has approved human growth hormone to treat children with pituitary gland deficiencies, two alpha interferons to treat a rare form of cancer, a monoclonal antibody to prevent kidney transplant rejection, and a hepatitis $B$ vaccine.

The way reviewers look at data also is changing. Experimenting with NDAs submitted electronically, via computer, reviewers can retrieve, examine and reanalyze data from the drug's clinical trials. They can find out, for example, how many patients had any combination of signs and symptoms, provided that information was reported in the NDA. Reviewers need written reports to accompany the computer data, but the electronic NDA does promise to reduce paperwork substantially.

While change is inevitable and often desirable, there are some constants at FDA. Safety and effectiveness, risk vs. benefit, will remain the pivotal issues in FDA drug review.

Dixie Farley is a member of FDA's public affairs staff. 
FOR IMMEDIATE RELEASE

Hauser Investor

Boulder, Colorado

Relations Department

May 7, 1992

(303) 443-4662

\section{HAUSER CHEMICAL RESEARCH INCREASES TAXOL PRODUCTION CAPACITY TO 130 KILOGRAMS PER YEAR}

Hauser Chemical Research, Inc. (NASDAQ: HAUS) announced the completion of process validation runs at its new production facility in Boulder, Colorado. Process validation is an important step in compliance with standard Food and Drug Administration (FDA) Good Manufacturing Practices (GMP) requirements. The plant has a production capacity of 100 kilograms of GMP taxol per year that can be fully achieved within 6 months and can be expanded when needed. According to the company's Chairman and Chief Executive Officer, Dean P. Stull, Ph.D., "Hauser's initial production facility is running at near capacity of 30 kilograms per year. The new facility will bring the company's total capacity to 130 kilograms per year."

Hauser is the only commercial supplier of bulk taxol for human use and has steadily improved the manufacturing process through technical innovation. As a result of these innovations, Hauser has reduced the Pacific yew bark needed to produce one kilogram of taxol to 16,000 pounds of bark. Hauser initially supplied bulk taxol to the National Cancer Institute for research purposes and currently manufactures bulk taxol, under a multi-year agreement, for Bristol-Myers Squibb Company which produces the final drug.

Hauser has also developed a method for the production of taxol from ornamental yew clippings which is similar to the current commercial process. Proving the new method on a pilot scale is under way. This could decrease significantly or eliminate the dependence on obtaining Pacific yew bark to support taxol production. The process for obtaining taxol from clippings will require FDA approval.

Taxol, an anti-cancer drug, is in clinical trials for refractory ovarian cancer, where it has achieved response rates up to $35 \%$; and trials for breast cancer, where response rates of up to $50 \%$ have been achieved. The compound is also being studied widely in the treatment of other cancers. Bristol-Myers Squibb is expected to file a New Drug Application for taxol for ovarian cancer with the FDA by mid-1992.

Hauser Chemical Research, Inc. is a chemical processor, specializing in the extraction and purification of high value natural products using its proprietary technologies. Additionally, through Hauser Laboratories, the Company provides interdisciplinary laboratory testing services, chemical engineering services and contract research and development. The company is based in Boulder, Colorado.

\section{\#\#\#\#}


CONTACT: Mike Trumbull

HAUSER CHEMICAL RESEARCH, INC.

General Manager Hauser Northwest, Inc. (503) 942-9655 (Oregon)

or

FOR IMMEDIATE RELEASE

Cottage Grove, Oregon/Boulder, Colorado

Neil A. Jans

April 28, 1992

President Hauser Northwest, Inc.

(303) 443-4662 (Colorado)

\section{BARK COLLECTION SEASON BEGINS; HAUSER PLANS TO EXCEED LAST YEAR'S COLLECTION OF 1,600,000 POUNDS}

Cottage Grove, Oregon/Boulder, Colorado - Hauser Northwest, Inc. and its parent company, Hauser Chemical Research, Inc. (NASDAQ: HAUS), the only commercial producer of bulk taxol, announced today that the yew bark collection season has begun in the Pacific Northwest. Hauser Northwest plans to exceed last year's collection of 1,600,000 pounds of Pacific yew bark from public and private land. Hauser has imposed tough new standards on yew bark harvesters for the 1992 bark collection program. The new standards are designed to improve efficiency and tracking of the harvest process and are based upon knowledge gained from last year's harvest.

"April begins our third harvest season as the authorized collector of yew bark for taxol used in clinical trials," said Mike Trumbull, General Manager of Hauser Northwest. Hauser employs its proprietary extraction process to produce taxol for Bristol-Myers Squibb and the National Cancer Institute. "We are pleased with last year's accomplishments. We exceeded our harvest goals by salvaging bark from trees in clear cuts and established an environmentally sound program employing over 500 people. We are excited to begin the new season and to increase the availability of this important new drug."

Hauser Northwest has made significant improvements since last year in procedures, coordination, monitoring and data gathering. "As always, bark harvesters authorized by Hauser Northwest will hoid valid permits from public agencies or private land owners. This year, we are using an improved set of trip tickets developed in cooperation with the Forest Service, BLM, private landowners and law enforcement personnel from a variety of agencies, "said Trumbull. Trip tickets can be obtained only from authorized yew bark collectors, and every load of bark will be tagged with a highly visible, color-coded trip ticket.

Although the current source of taxol is Pacific yew bark, Hauser has completed a pilot process for production of taxol from the clippings of ornamental or nursery grown yew trees. Dependence on yew bark collected in the wild is expected to decrease as these alternative sources become available over the next 2 - 4 years. The company is also working with other researchers on methods of producing taxol in the laboratory.

Hauser Chemical Research, Inc., (the parent company of Hauser Northwest, Inc.) is a chemical processor, specializing in the extraction and purification of high value natural products using its proprietary technologies. Additionally, through Hauser Laboratories, the Company provides interdisciplinary laboratory testing services, chemical engineering services and contract research and development. The company is based in Boulder, Colorado.

\section{\#\#\#\#}





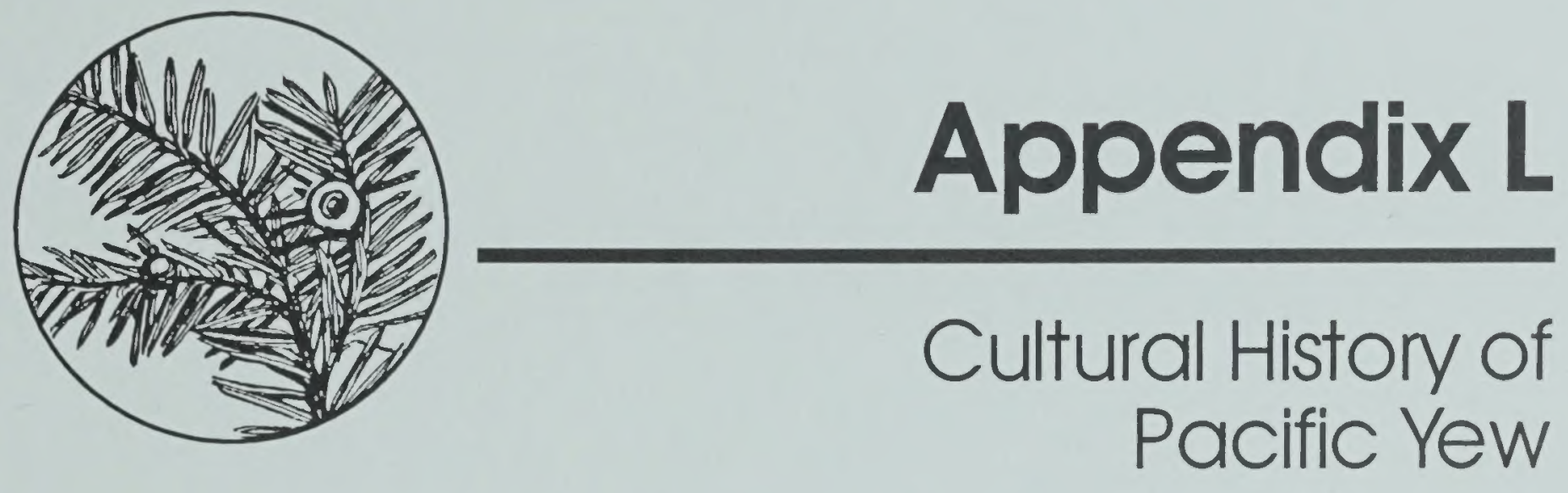


Changes Made Since the Draft EIS

Appendix L

No changes. 


\section{Appendix L}

\section{Cultural History (Taxus brevifolia)}

\section{Table of Contents}

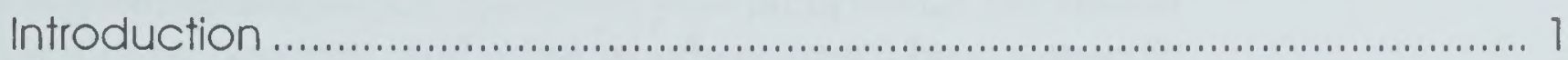

Native American Food Uses ............................................................... I

Uses in Native American Technology ................................................. I

Native American Medicinal Uses .......................................................... 2

Native American Religious/Spiritual Values ............................................. 3

Uses in Contemporary Woodworking ................................................... 4

Turned Work .................................................................................... 4

Furniture and Boxes ................................................................. 4

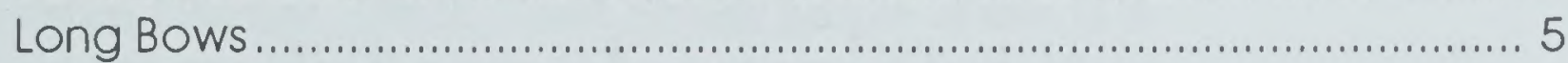

Musical Instruments .................................................................... 5

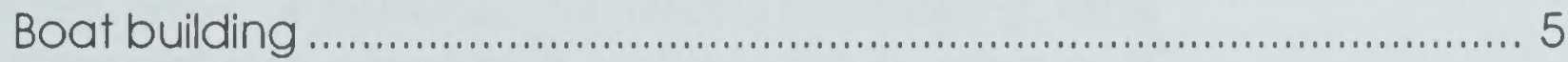

Carving and Sculpture ............................................................... 5

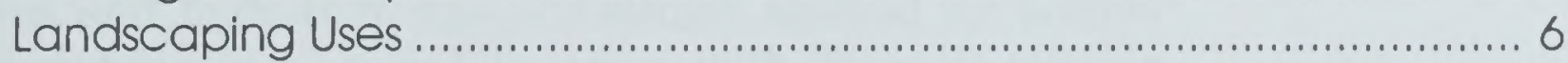

As an Indicator Species ............................................................. 6

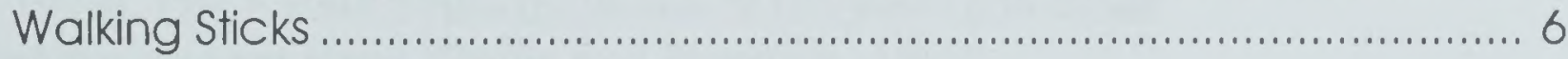

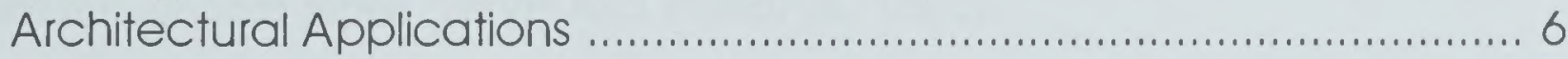

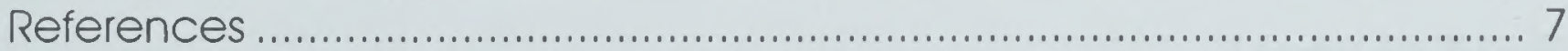



The Pacific yew has been a valuable though less frequently used tree of the Pacific Northwest since prehistoric times. Until recently, when taxol was extracted from the bark, the yew was primarily important for its wood, although bark and needles were used occasionally.

Yew trees normally grow widely scattered throughout the stands where they naturally occur. They are much smaller than the other conifers they grow with, and are generally much slower growing. These characteristics have kept yew from becoming a commercial species of great consequence. However, yew is currently harvested by boat builders, bowyers, and other woodworkers who are specifically seeking it out.

Some British Columbia native groups (Haida at Masset) reported eating the flesh of the aril but warned that if women ate too many, sterility would result (Turner, 1982). Of the few tribes that ate them, there was general recognition that only small quantities should be eaten (Turner, 1982). Coast Salish people of the U.S. generally did not consider the yew to be a source of food. Many groups did dry, grind, or pulverize the needles for smoking. Most often this "tobacco" was mixed with kinnikinnick (a mixture of dried leaves and bark that was sometimes smoked by Native Americans and pioneers) or in later years with domestic tobacco (Gunther, 1973). The Karuk Tribe made use of the yew (and other tree species) for tobacco pipes (Davis and Hendryx, 1992).

Yew was used by many northwestern Native American groups whenever a strong and tough wood was required. It was considered the premiere wood for construction of bows and other weapons from northern California to Canada and eastward to Montana (Davis and Hendryx, 1992; Gunther, 1973; Heizer, 1978; and Turner, 1979). Usually, the short bows were backed with elk sinew to provide extra strength. Extensive use was made of yew wood for harpoon shafts, spear shafts, arrows, canoe paddles, wedges, boxes, bowls, digging sticks, as well as knife and adz handles of the highest quality. It was also used by some groups for canoe bailers, mat sewing needles, awls, net making, halibut and other fish hooks, canoe spreaders, bark scrapers, fire tongs, combs, and

\section{Introduction}

\section{Native American Food Uses}

\section{Uses in Native American Technology}


gambling sticks, drum frames, household utensils (especially spoons), and spring poles for deer traps. One group of interior Salish people felt it was the best material available for snowshoe frames (Davis and Hendryx, 1992; Gunther, 1973; Stewart, 1984; Turner, 1979).

In recent years Native Americans have used yew for shovel and ax handles. Native carvers still value yew highly but have had more difficulty finding large enough pieces for carving. The heartwood is strongly preferred for carving.

The Okanogan ground yew heartwood into a powder and mixed it with fish oil to make paint. Pacific yew was referred to as the "bow plant" or the "wedge plant" by several Native American groups (Turner, 1979).

\section{Native American Medicinal Uses}

The yew was traditionally used where strength was required and logically the tree was used medicinally to impart strength where it was needed. Smooth yew sticks were used by young Swinomish men to rub themselves to gain strength. The Swinomish also used boughs to rub themselves after bathing (Gunther, 1973). The Chehalis would crush yew foliage in a bath for old people and children to make them sweat and to improve their condition (Gunther, 1973).

The Klallam would also boil the foliage but drank the resulting infusion to cure internal injury or pain. The Cowlitz would grind moistened leaves and use the resulting pulp for a wound dressing. The Quinault reported chewing the foliage and spitting the pulp on wounds. While this reportedly stings, it promotes healing (Gunther, 1973).

The Quinault and Karuk tribes are the only groups that report using the bark which they peeled, dried, and then boiled, making a tea. The Quinaults drank the liquid as a lung medication (Gunther, 1973), while the Karuk used it as a stomachache relief and for kidney problems (Davis and Hendryx, 1992). 
In an ethnographic survey of the Mt. Baker-Snoqualmie National Forest in 1981, the authors describe the religious and spiritual views of the Coast Salish people who occupied the coastal areas of southwestern British Columbia, the Puget Sound trough, and down the coast (Suttles, Onat, and Hollenbeck, 1981).

The report contrasts the Judeo-Christian beliefs in a supernatural god who exists on a higher plane than humans and directs their lives. In contrast, the Coast Salish believed that they were simply part of a world of plants and animals. The Salish felt that they existed in this world on equal footing with these other species.

Native Americans typically sought out a "guardian spirit," "power," or "what he has" from the non-human part of the world which would help them in their lives. This power was most often gained through a spirit quest and in most cases was of value to the recipient in everyday life the wolf might be of help to the deer hunter. A canoe carver might receive spirit help from the cedar tree from which he built a canoe or from the pileated woodpecker which also worked wood.

A significant point Suttles makes is that for the Coast Salish people, as well as many other Native American people, religion and spirituality were a part of everything they did. As indicated in the medical uses section, yew was used where strength was needed and it was also used where a strengthening of the spirit or power was required. It appears that yew may have been more important to Northwest Native Americans in the past than it is now:

- The Swinomish believed that they could receive power from the yew (Gunther, 1973).

- The Mount Baker-Snoqualmie inventory information suggests little current spiritual value although the Tulalip report decorating dancing shirts with small carved yew paddles (Suttles, Onat, and Hollenbeck, 1981).

- Whaling activity among the Makah was heavy with religious procedures. Though not practiced as it once was, whaling is a unique and important part of Makah culture (Waterman, 1920).

\section{Native \\ American \\ Religious/ \\ Spinitual Values}




\section{Uses in \\ Contemporary Woodworking}

Pacific yew wood is "even grained, very fine textured, heavy, very hard, very strong in bending and endwise compression, not stiff, very high in shock resistance, refractory to tools, finishes smoothly, [and is] very durable when exposed to conditions of decay" (Brown, 1949). Because of this scattered tree occurrence, commonly used logging systems and machinery are not practical for moving yew logs out of the woods. Harvest has required hand carrying logs or individually winching them out of the woods - the most inefficient ways of moving logs in today's production-oriented world.

Contemporary woodworkers have used yew wood in a fascinating number of ways. However, its scarcity and relatively small size limit its uses and applications. The current interest in harvesting yew bark could have a positive effect of making more yew wood available to woodworkers. Utilization of the wood would require loggers to work closely behind the bark peelers to move the logs out of the woods and protect them. The logs would have to be sealed on the ends and the logs stored in a shaded location; or the logs need to be sawn and the resulting billets or boards stickered and stored properly for air drying.

\section{Turned Work}

Pacific yew is currently used for a variety of items which are turned on a lathe. The wood is hard, dense, sands smoothly, and machines well. It is an excellent wood for turning spindles (bed posts, chair styles, tool handles and small spindles), bowls, and other vessels. Yew is occasionally turned for small specialty items, including the wooden parts of mechanical pen and pencil sets.

\section{Furniture and Boxes}

Yew is used in the construction of furniture of various kinds. Because it has become more difficult to obtain, it is now most often used for small accent pieces like wooden hinges, door and drawer pulls, and purely decorative features. It is used by northwest craftspeople for tables, chairs, bandsaw boxes, jewelry boxes, and accent features. Small pieces have also been used in marquetry. 


\section{Long Bows}

A pamphlet from the Oregon State Forestry Department written over 40 years ago, before the advent of the modern fiberglass bows, says: "The western yew (Taxus brevifolia) is more in demand for archery stock than any other wood. The tree is quite widely distributed in the state but the best bows are made from wood that is grown in the higher elevations where the tree growth is slow and hence results in a close-grained product. Specifications for archery billets are as follows: They must be 3 feet 8 inches in length and 1 $1 / 2$ inches in thickness and $21 / 2$ to 3 inches in width. Staves are 7 feet long with the same width and thickness as the billets" (Cronemiller, 1951). There are people who regularly cut a few trees for the construction of bows. Typically, bowyers harvest the wood from the forest, saw it into billets, and then season it, sometimes for decades.

\section{Musical Instruments}

Yew is used in the construction of a number of musical instruments, including flutes and recorders. The wood is also used for the parts of instruments; strips of yew have been used in the backs of lutes.

\section{Boatbuilding}

Yew is an excellent wood for boatbuilding, but its scarcity has limited the scope of its use. It steam bends well and is flexible and very rot-resistant. It has been used in wooden boats for steam-bent ribs, for knees, for breast hooks, and for edge grain decking. "Knees" and "breast hooks" on wooden boats were braces sawn from the natural bends in the tree where the grain would naturally curve and conform to the shape of the brace needed. These knees were much stronger than sawn braces (which cut across the grain) and simpler to fabricate than steam-bent braces (Wagner, 1985).

\section{Carving and Sculpture}

Yew carves beautifully and will take a fine polish from sharp carving knives. Its use is limited primarily by its scarcity and the small size of the material available. 


\section{Walking Sticks}

A variety of walking sticks are made of yew. Canes have been constructed of a limb with a portion of the bole carved into a handle or hook. Hiking staffs have been made of limbs or carved out of the bole.

\section{Architectural Applications}

Specially selected pieces of yew have been used for house posts, railings, mantel timbers, and vertical-grain stair treads.

Landscaping Uses

Pacific yew generally does not compare well with English or other hybridized yews for landscaping. The foliage is generally more yellow-green and the trees and shrub forms have less visual character than other species. However, there are some local populations that have proven attractive to native plant fanciers and have been utilized in gardens.

\section{As an Indicator Species}

Although this use of yew relates to other species of Taxus, it illustrates the range of uses of this plant. Aldo Leopold (naturalist and author of $A$ Sand County Almanac) was an avid hunter most of his life and eventually became an archer and bow maker. In the process of looking for yew with which to construct his bows, he observed many yew trees in forest environments, especially in his home state of Wisconsin and in German forests he visited on two occasions.

Leopold apparently first noticed the lack of yew in German forests where it had occurred. At the time the Germans were into highproduction forestry as well as wanting their forests to produce lots of deer. When he questioned Germans about the lack of yew he was told that it had been all harvested and exported to England for long bows in historic times. Leopold knew that very few growing yew would yield wood of a quality for the construction of a long bow. After more questioning he concluded that the management emphasis on deer production had pushed ungulate populations beyond the habitat's capability to feed them. After consuming the more palatable species, deer would begin to browse 
on conifers and in this case had consumed most of the yew in the country. In Leopold's home state of Wisconsin, there was a similar interest in managing as many deer as possible - to the detriment of the habitat (Flander, 1974; Leopold, 1953).

Barnett, H. G. 1937. Culture element distributions: VII, Oregon Coast. Anthropological Records, 1(3): 155-204.

Brown, H. P. et al. 1949. Textbook of wood technology. New York, NY: McGraw-Hill Book Co.

Cronemiller, Lynn F. et. al. 1951. Secret treasures in the forests. Pamphlet. Salem, OR: Oregon State Board of Forestry. $47 \mathrm{p}$.

Davis, Barbara J.; Hendryx, Michael. 1992. Plants and the people: the ethnobotany of the Karuk tribe. Yreka, CA: Siskiyou County Museum.

Flader, Susan L. 1974. Thinking like a mountain: Aldo Leopold and the evolution of an ecological attitude towards deer, wolves and mountains. Columbia, MO: University of Missouri Press. 284 p.

Gunther, Erna. 1973. Ethnobotany of western Washington: the knowledge and use of indigenous plants by Native Americans. Revised edition. Seattle, WA: University of Washington Press.

Heckert, Elizabeth. 1977. The people and the river: a history of the Takelma Indians of the upper Rogue River country. Ashland, OR: Aquarius Press.

Heizer, Robert F. (ed.). 1978. Handbook of North American Indians. California, Washington, D.C.: Smithsonian Institution. Volume 8. 
Leopold, Luna B. 1953. Round River: from the journals of Aldo Leopold. New York, NY: Oxford University Press. $173 \mathrm{p}$.

Renfro, Elizabeth. 1992. The Shasta Indians of California and their neighbors. Happy Camp, CA: Naturegraph Publishers, Inc.

Stewart, Hilary. 1984. Cedar: tree of life to the Northwest Coast Indians. Seattle, WA: University of Washington Press.

Suttles, Wayne; with Onat, Astrida Blunas and Hollenbeck, Jan L. (eds). 1981. The coast Salish need for wilderness. In: Inventory of Native American Indian use, practices, localities, and resources: study area on the Mt. Baker-Snoqualmie National Forest. Seattle, WA: USDA Forest Service, Mt. BakerSnoqualmie National Forest. 743 p.

Turner, Nancy J. 1979. Food plants of British Columbia Indians. Part 1: coastal people. Handbook No. 34. Victoria, B.C.: British Columbia Provincial Museum.

Turner, Nancy J. 1982. Plants of British Columbia Indian technology. Handbook No. 38. Victoria, B.C.: British Columbia Provincial Museum.

Wagner, Dick. 1985. A guide to Northwest boatbuilding woods. Published by the Center for Wooden Boats, 1010 Valley Street, Seattle, WA: P. 4-5 in Shavings.

Waterman, T.T. 1920. The whaling equipment of the Makah Indians. The University of Washington Publications in Political and Social Science. 1(1): 67 p. 


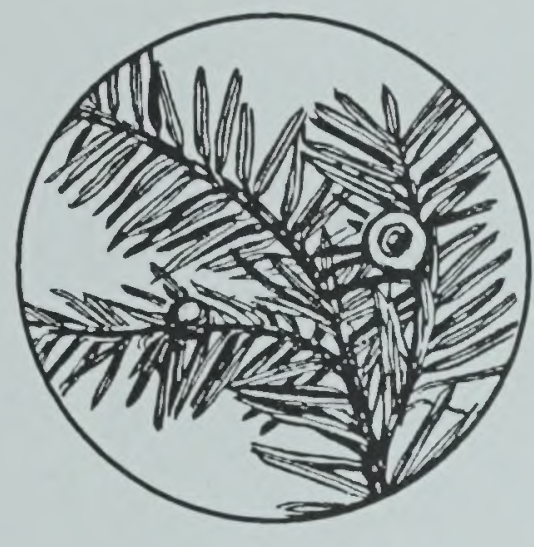

\section{Appendix M}

Ongoing and Needed Research for Pacific Yew 


\section{Changes Made Since the Draft EIS}

Appendix M

Added a more complete list of names of the people involved with various research projects. 


\section{Appendix M}

\section{Pacific Yew Research}

\section{Table of Contents}

Introduction.....

Research Needs

Bark Harvest

Reproduction and Culture ........................................................ 1

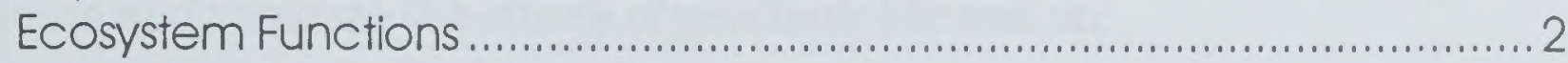

Timber Harvest ............................................................................ 3

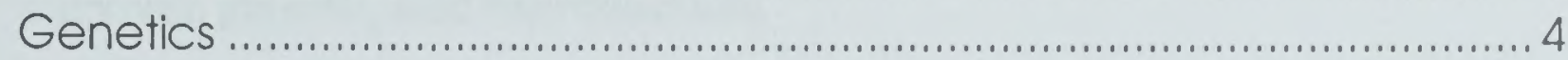

Foliage Harvest ...................................................................... 4

Yew Inventory Data .................................................................... 4

Ongoing and Future Research Projects ............................................... 6

A. Regeneration of Pacific Yew by Vegetative Propagation ................6 6

B. Using Protection Plants for Outplanted Pacific Yew..........................6 6

C. Culture, Physiology, and Genetics Influencing Taxane Yields ........... 7

D. Pacific Yew Regeneration by Seed ............................................... 7

E. Distribution of Taxol in Bark of Pacific Yew Trees ................................ 8

F. Assessing the Genetic Variability of Various Yew Taxa ...................... 8

$G$. Factors Influencing the Reproductive Output of Pacific Yew ............ 9

H. Environmental Factors Affecting Growth of Pacific Yew Across the Northwest ................................................................. 9

I. Genetic Improvement and Cultivation of Yew for Taxol ................. 10

J. Partial Bark-Stripping of Pacific Yew ................................................ 10

K. Characterization of Pacific Yew Decline in a Northwestern Oregon Stand ................................................... 10

L. Yew Ecology and Population Dynamics....................................... 1

M. Stump Sprouting of Pacific Yew ................................................ 11

N. Soil Seed Banks in Pacific Yew .................................................... 12

O. Understanding the Physiology of Taxus Seeds for the Purpose of Developing Preservation Protocols 

The amount of information we currently have about Pacific yew is relatively small, especially in comparison to that for other commercial forest tree species. For this reason, we include this appendix on needed research and current research projects in the Pacific Northwest involving Pacific yew.

Many of the research needs listed here were taken from "An Interim Guide to the Conservation and Management of Pacific yew." The projects listed under ongoing and future research projects are only those we are currently aware of.

\section{Bark Harvest}

1. Evaluate and compare the effects of yew bark harvest on:

a. survival, growth, and reproduction;

b. stand composition, structure, and density;

c. gene flow and genetic variability;

d. species response to environmental changes; and

e. whole ecosystem health.

2. Determine optimal harvest levels that will maximize current taxol production with the fewest adverse effects.

\section{Reproduction and Culture}

1. Evaluate and compare Pacific yew reproduction in natural and nursery environments.

2. Determine how stump height, season of cutting, and shading affect stump-sprout genesis, survival, and culture.

3. Determine what mycorrhizal associates are needed for successful out-planting.

4. Determine what measures are needed to mitigate browse effects on seedlings.

5. Evaluate and study the following:

a. the physiological factors and ecological conditions involved in asexual reproduction of Pacific yew;

\section{Introduction}

\section{Research Needs}


b. the frequency, size, and distribution of seed crops;

c. the unique nature of sexual reproduction in Pacific yew, including male/female ratios in natural stands, and effective pollination distance;

d. seed dormancy and longevity data;

e. the optimal collection season and type of cutting, rooting media, hormone treatments, temperature, and moisture for large-scale production of rooted cuttings; and

f. proper outplanting techniques necessary for successful reforestation of Pacific yew.

6. Determine whether the germination capacity of yew seeds is altered when they are ingested by vertebrates, and identify which species of birds and mammals are responsible for yew seed dispersal.

\section{Ecosystem Functions}

1. Examine Pacific yew's specific role as an ecosystem component, and evaluate the following.

a the effects of yew on the chemistry and biology of forest soils;

b. herbivore associations with yew;

c. the chemical and energetic quality of yew arils and foliage;

d. the role of yew and its decay-resistant wood in creating microclimate and microhabitat conditions;

e. relationships between Pacific yew and other plant and animal species;

f. correlations between taxol production and environmental stress; and

g. the effects of fire, predation (herbivore browsing and seed consumption), and competition from shrubs and overstory trees.

2. Determine what levels of yew harvest cause changes in the abundance or diversity of other vascular plants, vertebrates, invertebrates, fungi, and algae.

3. Determine how much yew could be harvested from streams without altering the physical, chemical, and biological attributes of those streams. 
4. Determine the nutritional value of yew foliage, including the levels of anti-herbivory chemicals.

5. Evaluate the effects of removing yew from winter range areas.

6. Determine how crucial Pacific yew fruit is to the total food requirements of fruit-eating vertebrates and invertebrates in forest systems.

7. Identify whether removal of yew from spotted owl nest areas or home ranges alters the survival or reproductive fitness of spotted owls.

\section{Timber Harvest}

1. Evaluate the effects of timber harvest on Pacific yew survival, growth, and reproduction.

2. The following questions regarding Pacific yew and timber harvest should be answered:

a. How do timber harvest and fragmentation affect Pacific yew and the populations of ungulates, fungal pathogens, and other organisms associated with yew?

b. How is yew affected by broadcast burning?

c. How is yew affected by soil compaction associated with mechanical slash piling?

d. How does the sudden release associated with clearcutting affect understory yew? How severe is the damage, and what is its duration? How does this release affect yew survival, crown dimension, needle type and orientation, diameter growth, bark thickness, and foliage production?

e. What are the effects of clearcuts-with-reserves, partial cuts, seed-tree, shelterwood, and selective-cut harvest systems, and how do they differ from the effects of conventional clearcutting?

f. How do the various silvicultural systems influence stump sprouting, layering, seed production, seedling establishment, and browse production in Pacific yew? 


\section{Genetics}

1. Identify population structures to provide mating-systems data, and separate genetic from environmental effects.

2. Determine the extent of genetic variation within and between yew populations.

3. Develop population viability models.

4. Determine the actual amount of genetic variability of Pacific yew.

\section{Foliage Harvest}

1. Foliage-harvesting methods should be evaluated, and compared in terms of their effects on yew survival, growth, and reproduction.

2. Determine the effects of foliage harvest on the following:

a. stand composition, structure, and density;

b. the local gene pool and gene exchange;

c. evolution in response to changes in the environment; and

d. the ecosystem.

\section{Yew Inventory Data}

In 1991 and 1992, the Pacific Northwest Region (R-6), USDA Forest Service conducted an extensive inventory of Pacific yew. The two primary reasons for the inventory were: 1 . to characterize the current condition of yew, specifically by providing estimates of quantity and area distribution of yew; and 2. to characterize the existing vegetation on inventory plots to provide data for analyzing the relation of yew to existing vegetation.

The inventory was conducted by distributing sample plots systematically within the defined population. The population was also stratified using remotely sensed data. The population was restricted to National Forest System Land on seven National Forests in Oregon and Washington. The national forests included were: Siskiyou, Rogue River, Umpqua, Willamette, Mt. Hood, Gifford Pinchot, and the southern half of Mt. Baker-Snoqualmie. 
Within these forests, the population was further restricted to a mid-level elevational zone. About 1800 field plots were established and measured. The primary sampling unit was a five-acre square plot. The five-acre plot was subsampled in several different ways to obtain data for a large number of different response variables.

The R-6 inventory resulted in a large data base on Pacific yew, a species for which very little information has previously been available. The inventory data represents a tremendous and valuable resource for expanding what is known about Pacific yew. A comprehensive plan for analyzing these data is being developed. This plan includes the following steps:

1. Gather questions to be addressed - Initially identify a large, exhaustive list of questions for which the database might provide information. Questions should include those by land/resource managers as well as research questions.

2. Group questions into logical categories - These groupings would be the beginning of identifying individual analytical studies to be conducted to completely analyze the database.

3. Identify participants and their roles - Identify the roles and responsibilities of the people who will be actually be involved in the analytical studies.

4. Determine and secure resources needed to conduct studies - The primary resources needed are funds and employees' time.

5. Develop time frame - Develop a time table for completion of the entire plan, including each identified analytical study. Studies should be carried out concurrently.

6. Plan for publication - Include a plan for comprehensive documentation of the results from the analytical studies. 
Ongoing and Future Research Projects

\section{A. Regeneration of Pacific Yew by Vegetative Propagation}

Who is involved:

- Nan Vance, USDA Forest Service, Pacific Northwest Research Station, Corvallis, Oregon; and

- David Steinfeld, J. Herbert Stone Nursery, USDA Forest Service, Rogue River National Forest, Central Point, Oregon.

Objectives:

- Determine optimization of rooting and growing procedures, growing environment, timing and sticking, rooting and lifting.

Time Frame:

- Winter 1990 to Spring 1993.

\section{B. Using Protection Plants for Outplanted Pacific Yew}

Who is involved:

- Don Copes, Don Minore, Nan Vance, USDA Forest Service, Pacific Northwest Research Station, Corvallis, Oregon; and

- Bill Randall, USDA Forest Service, Siuslaw National Forest, Corvallis, Oregon.

Objectives:

- Determine if Pacifc yew stecklings inoculated with VA mycorrhizal will show greater growth and vigor than non-mycorrhizal stecklings.

- Determine if there is a difference in two species of Glomus (a VA mycorrhizal fungus) performance of Pacific yew stecklings.

Time Frame:

- Fall 1992 to Spring 1994. 


\section{Culture, Physiology, and Genetics Influencing Taxane Yields}

Who is involved:

- Rick Kelsey and Nan Vance, USDA Forest Service, Pacific Northwest Research Station, Corvallis, Oregon.

- David Steinfeld, J. Herbert Stone Nursery, USDA Forest Service, Rogue River National Forest, Central Point, Oregon

Objectives:

- Assess genetic variability of taxanes in Pacific yew across a broad geographic range.

- Determine variation in taxane concentration in different yew tissues and effect of light on taxane concentrations.

- Determine seasonal and diurnal effects on taxanes in foliage and bark of Pacific yew.

- Determine effect of nitrogen and light on growth and taxane concentrations of Pacific yew propagated by cuttings.

Time Frame:

- 1990 to 1993.

\section{Pacific Yew Regeneration by Seed}

Who is involved:

- Nan Vance, USDA Forest Service, Pacific Northwest Research Station, Corvallis, Oregon.

Objectives:

- Develop procedures for handling, storing, and germinating Pacific yew seed.

- Understand dormancy and stratification requirements of seed.

Time Frame:

- Two or more years. 


\section{E. Distribution of Taxol} in Bark of Pacific Yew Trees

Who is involved:

- Nan Vance and Rick Kelsey, USDA Forest Service, Pacific Northwest Research Station, Corvallis, Oregon; and

- Tom Sabin and Lorna Jones, Department of Forest Science, Oregon State University, Corvallis, Oregon.

Objectives:

- Determine differences in taxol concentrations in the bark at different locations on bole and limbs.

- Develop a model to determine distribution of taxol in bark of bole and limbs and to more accurately determine bark mass on trees with simple field measurements.

Time Frame:

- 1992.

\section{F. Assessing the Genetic Variability of Various Yew Taxa}

Who is involved:

- Nan Vance, USDA Forest Service, Pacific Northwest Research Station, Corvallis, Oregon; and

- Alex Krupkin and Valerie Hipkins, Department of Forest Science, Oregon State University, Corvallis, Oregon

Objectives

- Assess techniques that would provide genetic markers.

- Analyze the genetic variability within and among yew species and assess genetic distance among taxa.

Time Frame:

- Study completed and manuscript in progress. 


\section{G. Factors Influencing the Reproductive Output of Pacific Yew}

Who is involved:

- Peyton Owston, Tom Spies, Nan Vance, Don Minore, and Leon Liegel, USDA Forest Service, Pacific Northwest Research Station, Corvallis, Oregon;

- Mark Wilson and Stephen deFazio, Department of Botany and Plant Pathology, Oregon State University, Corvallis, Oregon; and

- Gerald Krantz, Department of Enternology, Oregon State University, Corvallis, Oregon.

Objectives:

- Determine site and biological factors that influence seed production.

- Determine the importance of sexual reproduction in maintaining viable yew populations versus vegetative propagation.

Time Frame:

- 1992 to 1994.

\section{H. Environmental Factors Affecting Growth of Pacific Yew Across the Northwest}

Who is involved:

- Leon Liegel, USDA Forest Service, Pacific Northwest Research Station, Corvallis, Oregon.

Objectives:

- Identify site and/or stand factors associated with optimum yew growth.

- Characterize the landscape, understory, wildlife damage, and reproduction attributes of yew stands sampled within three physiographic provinces (dry, moist, and wet).

- Compare $80^{\prime}$ to 100 -year radial increment growth rate differences between yew trees of different diameters at the same site.

Time Frame:

- Summer 1992 to Summer 1993. 


\section{Genetic Improvement} and Cultivation of Yew for Taxol

Who is Involved:

- Nick Wheeler, Keith Jeck, Sue Masters, Carol O'Brien, and Val Wyant, Weyerhaeuser Company, Rochester, Washington.

Objectives:

- Estimate genetic parameters of taxane yield content.

- Determine the amount of variation in taxane yield.

Time Frame:

- Five-year study.

\section{J. Partial Bark-Stripping of Pacific Yew}

Who is Involved:

- Don Minore, USDA Forest Service, Pacific Northwest Research Station, Corvallis, Oregon.

Objectives:

- Relate partial removal of yew bark to subsequent tree vigor and growth.

Time Frame:

- 8 to 10 years.

K. Characterization of Pacific Yew Decline in a Northwestern Oregon Stand

Who is Involved:

- Catherine Parks, Art Tiedimann, Larry Bednar, USDA Forest Service, Pacific Northwest Research Station, La Grande, Oregon;

- Jerry Beatty, USDA Forest Service, Forest Pest Management, Portland, Oregon; and

- Edward Bottum, La Grande, Oregon. 


\section{Objectives:}

- This is intended to be a pilot study to evaluate and document the condition of Pacific yew in a limited area, to assess damage and mortality (mostly due to bark stripping by elk), and inventory the study area for yew reproduction.

Time Frame:

- Spring 1993 and 1994.

\section{Yew Ecology and Population Dynamics}

Who is involved:

- Tom Spies and Rick Busing, USDA Forest Service, Pacific Northwest Research Station, Corvallis, Oregon.

Objectives:

- Evaluate the abundance of Pacific yew with respect to stand successional condition.

- Estimate population demographic characteristics of yew populations in natural stands.

- Develop population models to evaluate the effects of different levels of exploitation on the stability of wild populations of the species.

Time Frame:

- 1993 and 1994

\section{Stump Sprouting of Pacific Yew}

Who is involved:

- Don Minore, USDA Forest Service, Pacific Northwest Research Station, Corvallis, Oregon.

Objectives:

- Relate stump characteristics, season of cutting, and micro-environment to the initiation, growth, and survival of epicormic branches on Pacific yew stumps, so that successful asexual reproduction can be maximized in harvested yew stands.

Time Frame:

- Two or more years. 


\section{N. Soil Seed Banks in Pacific Yew}

Who is involved:

- Don Minore and Roger Ottmar, USDA Forest Service, Pacific Northwest Research Station, Corvallis, Oregon.

Objectives:

- Measure the occurrence and size of soil seed banks under representative female yew trees.

- Investigate conditions that promote the germination of dormant yew seeds (e.g. exposure to light, temperature, moisture, and fire).

Time Frame:

- 1993 and 1994.

O. Understanding the Physiology of Taxus Seeds for the Purpose of Developing Preservation Protocols

Who is involved:

- Christina Vertucci, National Seed Storage Laboratory, Fort Collins, Colorado; and technical support, USDA Forest Service, Rocky Mountain Research Station, Fort Collins, Colorado; and

- Nan Vance, USDA Forest Service, Pacific Northwest Research Station, Corvallis, Oregon; and

Objectives:

- Determine seed sensitivity to desiccation at different stages of seed development and maturity.

- Assess seed viability and germination potential.

- Determine, where possible, those factors that contribute to deep embryo/seed dormancy.

- Test the efficacy of cryopreservation of germinable seeds.

Time Frame:

- Results will be reported in 1993. 


\section{Appendix N}

Pacific Yew Act 


\section{Changes Made Since the Draff EIS Appendix N}

Changed this appendix to contain "The Pacific Yew Act of 1992." Pacific yew harvest policies which were previously contained in this appendix have been made a part of the process record. 
Public Law 102-335

\section{2d Congress}

\section{An Act}

To provide for the management of Federal lands containing the Pacific yew to ensure a sufficient supply of taxol, a cancer-treating drug made from the Pacific yew.

Be it enacted by the Senate and House of Representatives of the United States of America in Congress assembled,

\section{SECTION 1. SHORT TITLE.}

(a) SHORT TrTLE.-This Act may be cited as the "Pacific Yew Act".

SEC. 2. FINDINGS, PURPOSES, AND DEFINITIONS.

Aug. 7, 1992

[H.R. 3836]

Pacific Yew

Act.

Forests and

forest products.

16 USC 4801

note.

16 USC 4801

(a) FINDINGS. - Congress finds the following:

(1) Over 12,000 women die each year from ovarian cancer and 44,500 women die from breast cancer.

(2) Taxol, a drug made from the Pacific yew (Taxus brevifolia), has been successful in treating ovarian cancer in clinical trials and shows promise in the treatment of breast cancer and other types of cancer.

(3) The production of small amounts of taxol currently requires the use of large numbers of Pacific yew.

(4) The Pacific yew is a slow-growing tree species found in the Western United States.

(5) Significant numbers of Pacific yew trees are found in old-growth forests on Federal lands in the Pacific Northwest.

(6) Before the importance of taxol was discovered, the Pacific yew was considered a trash tree and was often burned in slash piles after timber operations.

(7) Remaining Pacific yew resources must be carefully managed in order to ensure a steady supply of taxol for the treatment of cancer, while also providing for the long-term conservation of the species.

(8) Appropriate management guidelines must be implemented promptly in order to prevent any wasting of the Pacific yew in current and future timber sales on Federal lands, while successful and affordable alternative methods of manufacturing taxol are being developed.

(b) PURPOSES.-The purposes of this Act are to contribute to the successful treatment of cancer by ensuring that Pacific yew trees located on lands of the National Forest System and on public lands administered by the Bureau of Land Management are managed to

(1) provide for the efficient collection and utilization of those parts of the Pacific yew that can be used in the manufacture of taxol for the treatment of cancer;

(2) provide for the sale of Pacific yew from such lands for the commercial production and subsequent sale of taxol at a reasonable cost to cancer patients; 
106 STAT. 860

PUBLIC LAW 102-335-AUG. 7, 1992 and

(3) ensure the long-term conservation of the Pacific yew;

(4) prevent the wasting of Pacific yew resources while successful and affordable alternative methods of manufacturing taxol are being developed.

(c) SECRETARY CONCERNED DEFINED.-For purposes of this Act, the term "Secretary concerned" means-

(1) the Secretary of Agriculture, with respect to lands and interests in lands under the jurisdiction of the Forest Service; and

(2) the Secretary of the Interior, with respect to lands and interests in lands under the jurisdiction of the Bureau of Land Management.

16 USC 4802. SEC. 3. PACIFIC YEW CONSERVATION AND MANAGEMENT.

(a) PACIFIC YEW PoLICY.-The Secretary of Agriculture and the Secretary of the Interior shall pursue a conservation and management policy with respect to lands and interests in lands under the jurisdiction of the Forest Service or the Bureau of Land Management, which contain the Pacific yew in order to-

(1) provide for the sustainable harvest of Pacific yew, or Pacific yew parts, in accordance with relevant land and resource management plans for the manufacture of taxol; and

(2) provide for the long-term conservation of the Pacific yew in the wild.

(b) CONTENT OF POLICY.-The conservation and management policy required by subsection (a) shall ensure that-

(1) in planning harvests of the Pacific yew, priority be given first to areas in which timber has been cut but Pacific yew trees have not been removed, second to areas in which timber is already sold but remains uncut, third to areas scheduled for timber sale in the near future, and fourth to those other areas where commercial and salvage timber sales are allowed under existing laws;

(2) individual Pacific yew trees are utilized with little or no waste;

(3) to the extent that timber harvesters' health and safety will not be jeopardized, the bark is harvested from Pacific yew trees in timber sale areas before the harvest of other timber resources;

(4) whenever Pacific yew trees are harvested, they are(A) cut using methods designed to allow for resprouting from the stump; and

(B) replanted where necessary to maintain the species in the ecosystem; and

(5) timber management and harvest activities are carried out in a manner that will minimize any adverse effects on the survival and regeneration of Pacific yew trees.

(c) Application of POLICY to Timber Harvesting.-

(1) APPLICATION.-The Secretary concerned shall ensure that timber sales awarded after the date of the enactment of this Act, and timber sales completed before that date but still unharvested on that date, are conducted in accordance with-

(A) the policy expressed in subsection (a); and

(B) the relevant land and resource management plans of the Secretary concerned. 
(2) Consultation UNDER ENDANGERED SPECIES ACT.-If the Secretary concerned foresees the need to harvest Pacific yew in an area for which an opinion issued under subsection (b)(3)(A) of section 7 of the Endangered Species Act of 1973 (16 U.S.C. 1536) has concluded that a commercial timber sale is likely to jeopardize the continued existence of an endangered or threatened species or destroy or adversely modify critical habitat identified for the species under that Act, the Secretary concerned shall immediately initiate consultation under that section to determine the effect on endangered and threatened species and critical habitat of harvesting only Pacific yew trees.

(d) INVENTORY OF PACIFIC YEW.-Not later than 6 months after the date of the enactment of this Act, each Secretary concerned shall complete the ongoing inventory of Pacific yew on lands under the jurisdiction of the Secretary concerned.

SEC. 4. RESEARCH.

Each Secretary concerned shall encourage and, where appropriate, assist in research regarding-

(1) the ecology of the Pacific yew;

(2) the development of alternative methods of procuring taxol, including utilization of other yew parts in addition to bark, the sustainable harvest of yew needles, and the utilization of other yew species; and

(3) the propagation of Pacific yew and other yew species in agricultural or commercial settings.

SEC. 5. COLLECTION AND SALE OF PACIFIC YEW RESOURCES.

(a) ENFORCEMENT AND ACCESS.-The Secretary concerned shall ensure the development, implementation, and enforcement of processes for the collection and sale of Pacific yew resources that will minimize the illegal harvest and sale of such resources. The Secretary shall also ensure that access to Pacific yew resources is allowed in a timely manner such that collection of Pacific yew parts can occur before the taxol properties of such parts are degraded.

(b) Negotiated Sales.-

(1) FOREST SERVICE SALES.-Notwithstanding section 14 of the National Forest Management Act of 1976 (16 U.S.C. 472a), the Secretary of Agriculture may negotiate sales of Pacific yew on lands under the jurisdiction of the Forest Service at not less than appraised value, to parties manufacturing taxol in the United States in accordance with section 505 of the Federal Food, Drug, and Cosmetic Act (21 U.S.C. 355) for use in humans.

(2) BUREAU OF LAND MANAGEMENT SALES.-Notwithstanding the Materials Act of 1947 (30 U.S.C. 601-604), the Federal Land Policy and Management Act of 1976 (43 U.S.C. 1701 et seq.), and Act of August 28, 1937 (43 U.S.C. 1181a-1181f), the Secretary of the Interior may negotiate sales of Pacific yew on lands under the jurisdiction of the Bureau of Land Management at not less than appraised value, to parties manufacturing taxol in the United States in accordance with section 505 of the Federal Food, Drug, and Cosmetic Act (21 U.S.C. 355 ) for use in humans.

(3) DisPosition OF UNUTILIZEd MATERIAL.-The Secretary concerned shall, to the extent practicable, make material unutilized by purchasers of Pacific yew available to others. 
106 STAT. 862

PUBLIC LAW 102-335-AUG. 7, 1992

(4) LIMITS ON OTHER SALES.-Except as provided in paragraphs (1), (2), and (3), the Secretary concerned shall not sell Pacific yew for commercial use.

(5) USE OF RECEIPTS.-The Secretary concerned may use amounts received from the sale of Pacific yew under this section to pay the costs incurred by the Secretary concerned associated with the harvest and sale of Pacific yew.

(c) RECORD KEEPING.-The Secretary concerned shall keep accurate records of all sales, bark removal, or other harvest of the Pacific yew. The records shall include the following information:

(1) The date of sale (where applicable) and the date of harvest.

(2) The names of the persons performing the harvest.

(3) The record of authorization for the harvest.

(4) The location and size of the area in which the harvest occurred.

(5) The quantity of Pacific yew harvested, including, to the extent practicable, the number of trees harvested, volume of bark harvested, and weight of bark harvested.

(d) EFFECT ON PRIOR SALES.-With respect to Pacific yew harvested before the date of the enactment of this Act on lands under the jurisdiction of the Forest Service or the Bureau of Land Management, the Secretary concerned may permit taxol derived from that Pacific yew to be used for purposes other than research if the Secretary of Health and Human Services certifies to the Secretary concerned that such permission-

(1) will increase patient access to taxol treatment; and

(2) will not result in insufficient supplies of taxol for clinical research.

16 USC 4805. SEC. 6. RELATION TO OTHER LAWS.

Nothing in this Act shall be interpreted as modifying the provisions of the Forest and Rangeland Renewable Resources Planning Act of 1974 (16 U.S.C. 1600 et seq.), the Federal Land Policy and Management Act of 1976 (43 U.S.C. 1701 et seq.), or the Endangered Species Act of 1973 (16 U.S.C. 1531 et seq.), except as explicitly provided in section 3.

16 USC $4806 . \quad$ SEC. 7. REPORT TO CONGRESS.

Not later than one year after the date of the enactment of this Act (and annually thereafter), each Secretary concerned shall submit to the Committee on Merchant Marine and Fisheries, the Committee on Interior and Insular Affairs, and the Committee on Agriculture of the House of Representatives, and the Committee on Environment and Public Works, the Committee on Energy and Natural Resources, and the Committee on Agriculture, Nutrition, and Forestry of the Senate a report containing the following:

(1) A judgment as to whether sufficient amounts of Pacific yew have been harvested, and can continue to be harvested for the next year, to supply necessary amounts of taxol required for medicinal purposes, together with a summary of the information on which the judgment is based.

(2) The results of the Pacific yew inventory required by section $3(\mathrm{~d})$.

16 USC 4807. SEC. 8. EXPIRATION OF REQUIREMENTS.

The Secretary of Health and Human Services shall determine when quantities of taxol sufficient to satisfy medicinal demands are available from sources other than Pacific yew trees harvested 
on Federal lands and notify each Secretary concerned upon making such determination. If the Secretaries concerned concur, they shall jointly notify the relevant congressional committees, as listed in section 7, at which time the requirements of this Act shall expire.

Approved August 7, 1992.

LEGISLATIVE HISTORY - H.R. 3836 (S. 2851):

HOUSE REPORTS: No. 102-552, Pt. 1 (Comm. on Merchant Marine and Fisheries), Pt. 2 (Comm. on Interior and Insular Affairs), and Pt. 3 (Comm. on Agriculture).

SENATE REPORTS: No. 102-323 (Comm. on Energy and Natural Resources).

CONGRESSIONAL RECORD, Vol. 138 (1992):

July 7 , considered and passed House

July 23 , considered and passed Senate. 



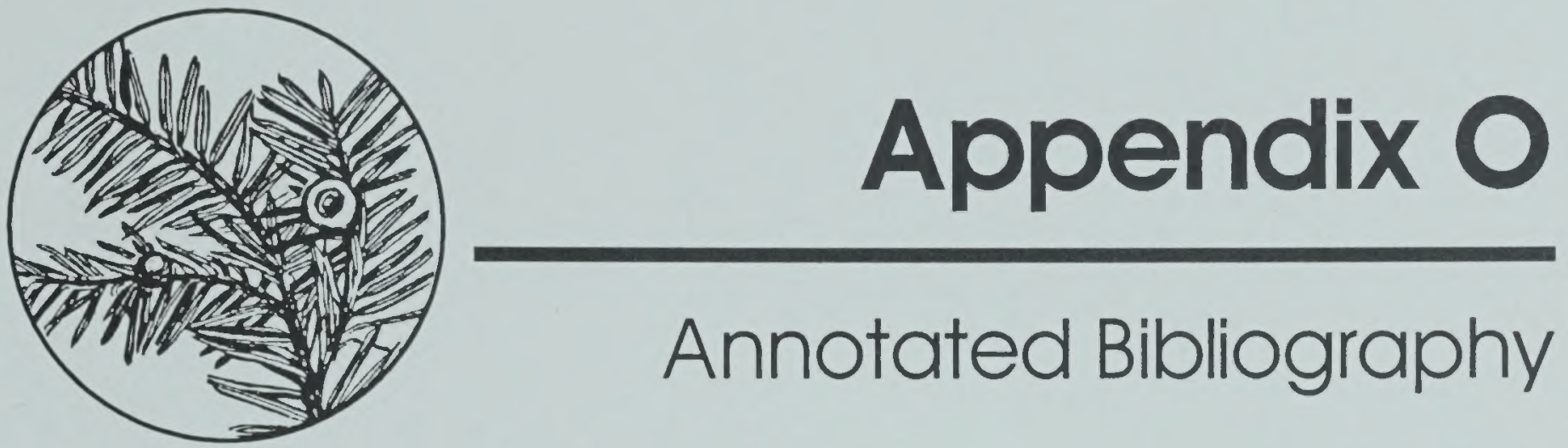




\section{Changes Made Since the Draff EIS}

\section{Appendix 0}

No changes. 


\section{A}

Alaback, Paul B. 1989. Structure and composition of lowelevation forests in research natural areas of southeast Alaska. Natural Areas Journal. 9(1): 27-39.

Abstract - Pristine examples of low elevation productive old growth forest were studied in permanent plots established in three existing and four proposed research natural areas in coastal Alaska. The study was designed to document changes in the structure and composition of these forests along a latitudinal gradient and to provide a baseline for future studies. To date the research natural areas in coastal Alaska have not been selected to represent the complete range of ecosystem and climatic diversity. Additional research natural areas are needed to represent the diverse geologic and climatic features of this vast region and to provide a more comprehensive baseline to compare against management activities in coastal Alaska and in other forest types.

Allison, Taber D. 1990. Pollen production and plant density affect pollination and seed production in Taxus canadensis. Ecology. 71(2): 516-522.

Abstract - Mean pollen production and mean nearest neighbor distance were recorded for several populations of Taxus canadensis and correlated with the proportion of ovules pollinated and seed set. Distance and pollen production together explained 86 percent of the variation in pollination success, each variable significantly adding to the regression when adjusting for the other. Seed set was correlated significantly with pollen production and nearest neighbor distance separately, but the multiple regression including the latter two variables was not significant. Seed set was correlated most strongly with pollination success and mean ovule production, suggesting that variation in seed set among Taxus populations was a combination of differences in pollen and resource availability. 
[Anon]. 1990. [News Brief]. Environmental Defense Fund. September $19.2 \mathrm{p}$.

Abstract - This news brief discusses the petition by environmental groups and cancer researchers to list the Pacific yew tree as a threatened species under the Endangered Species Act. The petition was sent to Interior Secretary Manuel Lujan on September 19, 1990. The news brief gives a short history of taxol discovery and its use as a promising new anticancer drug. The brief goes on to state that despite the fact that taxol is in short supply and its source, the Pacific yew tree, is a rare and extremely slow-growing species, neither the Forest Service nor the BLM recognize the tree as "sensitive." Among those groups who signed the petition are the Environmental Defense Fund, the Center for Marine Conservation, Defenders of Wildlife, the National Wildlife Federation, the Natural Resources Defense Council, the Wilderness Society, Friends of the Ancient Forests, and the Oregon Natural Resources Council.

[Anon]. 1990. Pacific yew bark for cancer research. Community Relations Update. Newsletter of Timber Resource Education Inc. December.

Abstract - This article briefly discusses the Pacific yew as the source of the new canoer fighting drug, taxol. The National Canoer Institute is working jointly with Bristol-Myers Squibb to develop this drug. Further, Hauser Chemical Research, Inc. has been selected as the supplier of yew bark and taxol for these efforts. Current taxol collecting techniques and developments are also discussed.

[Anon]. 1991. Government moves to increase taxol supply. Journal of the National Cancer Institute. 83(15): 1054-1056. Abstract - While taxol has shown great promise as an anticancer agent, the drug is in short supply because of the rarity of its source, the Pacific yew tree. Taxol currently is derived from the bark of the Pacific yew, which is found mainly in the old growth forests of the Pacific Northwest. The article discusses the cooperative research and development agreement signed between the National Cancer Institute and Bristol-Myers Squibb Company. The article also discusses semisynthesis of taxol and future outlook for taxol supply. 
[Anon]. 1991. Laboratory scientists mount intensive probe of taxol's mechanism of action. Journal of the National Cancer Institute. 83(13): 904-906.

Abstract - With taxol continuing to show promise as an anticancer drug in clinical trials, scientists are even more determined to completely understand how the compound works. A primary goal is to develop a synthetic substitute for natural taxol. Taxol is a complex molecule. The compound currently is derived from the bark of the Pacific yew tree. Taxol acts as a mitotic spindle poison which interferes with cancer cells' structural apparatus. Most plant-derived anticancer drugs work to stop cell division by inhibiting production of microtubules, but taxol promotes microtubule production and stabilizes them to the point that the cell is unable to divide. Scientists are also trying to define the threedimensional structure of the molecule. Researchers are using nuclear magnetic resonance imaging and computer modeling in their efforts to understand taxol.

[Anon]. 1991. [News Brief]. Journal of Forestry. October: 8-9.

Abstract - This news brief discusses the awareness of the need for accelerated production of the anticancer drug taxol, while also recognizing concern for the environment. The Bureau of Land Management and the National Forest System both signed agreements with Bristol-Myers Squibb to provide for the collection of bark from the Pacific yew to produce this drug. According to the National Cancer Institute (NCI), sixty pounds of bark-the bark from approximately three yew trees - is needed to produce two grams of pure drug to treat one cancer patient. NCI plans to fund nine to 12 separate projects to produce taxol synthetically and biologically.

[Anon]. 1991. [News Brief]. Journal of Forestry. November: 11.

Abstract - This news brief discusses two avenues of taxol production for fighting cancer. First, a tissue-culture process being perfected by biotechnologists working at Cornell University could produce virtually limitless quantities of taxol in two to five years. Cell lines have been developed that are much more productive than the cells in yew bark in making 
taxol. Meanwhile, researchers at the USDA Forest Service's Forest Products Laboratory are researching ways to extract taxol more efficiently from the wood as well as the bark of the Pacific yew.

[Anon]. 1991. Pacific yew: the mismanaged miracle. ONRC Journal. Fall: 17.

Abstract - The article states that taxol offers the best hope for an effective treatment for cancer seen in 15 years. However, a problem lies with the Bureau of Land Management and the Forest Service's short-sighted management of the Pacific yew. Full utilization of the yew as one of the management guidelines was not adopted. Small yew trees and bushes have been burned following logging rather than being made available for taxol production. Also, the Forest Service and the BLM have not consistently implemented guidelines giving yew trees the best chance of resprouting after being cut down. Other sources of taxol are currently being developed, including: (1) a process for extracting Baccatin III from needles of the English yew and chemically converting Baccatin into taxol and (2) production of taxotere by Rhone-Poulenc Rorer. About ten times as much taxol can be produced from English yew leaves as from as from Pacific yew bark.

[Anon]. 1991. [News Brief]. Taxol Summary. National Cancer Institute. Rockville, Maryland. February 6. 2 p.

Abstract - This newsbrief gives a history of taxol isolation and production, and discusses current drug supply. Taxol, a plantderived anticancer drug, was first isolated from the western yew tree, Taxus brevifolia. It is also found in other members of the genus. Clinical trials with taxol have been encouraging, with a 30-35 percent response rate in over 200 patients suffering from recurrent ovarian cancer. The National Cancer Institute has signed a cooperative research and development agreement with Bristol-Myers Squibb Company. Large numbers of yew trees are necessary for extracting significant amounts of taxol. For this reason, other methods of extracting and synthesizing taxol are being pursued. Researchers are investigating such approaches as propagating high-yielding yew specimens, cultivating plant tissues, and semi-synthesizing taxol. 
[Anon]. 1991. [News Brief]. U.S. Fish and Wildlife Service, Region 1. January 9.2 p.

Abstract - Citing abundance of trees and few threats to the species, the Fish and Wildlife Service declared there is not enough scientific evidence currently available to list the $\mathrm{Pa}$ cific yew as a threatened species. The agency claims the Pacific yew exists on at least 2.5 million acres of land in California, Idaho, Oregon, and Washington. Environmental groups requesting the listing claim the yew exists on only 1.2 million acres in the lower 48 states. Despite its commercially viable status as a source of the cancer-fighting drug taxol, and the fact that few laws protect it, the Fish and Wildlife Service says no substantial case has been made to warrant listing at this time. The Fish and Wildlife Service will consider the status of the species, and not the need for the abundance of taxol, in judging whether to propose listing. The agency was petitioned in September, 1990, by the Environmental Defense Fund, the Center for Marine Conservation, and two medical researchers.

[Anon]. 1992. [News Brief]. Weyerhaeuser Company. January 8: $1 \mathrm{p}$.

Abstract - This news brief discusses the supply agreement recently signed between the Weyerhaeuser and Bristol MyersSquibb companies. Weyerhaeuser is to become a future major supplier of taxol-containing yew trees over the next 10 years. Weyerhaeuser will grow large numbers of yew trees in its western nurseries. In addition to the supply agreement, Weyerhaeuser signed a cooperative research agreement with Bristol Myers-Squibb in August, 1991, to determine whether cultivating domestic yew trees would be viable for taxol production. The supply agreement and the research agreement are closely linked. Weyerhaeuser's research efforts are partially funded under a competitive grant from the National Cancer Institute. Weyerhaeuser has established the largest Pacific yew genetics nursery study currently in existence. 
[Anon]. [n.d.]. Trees and tall shrubs. In: Poisonous garden and crop plants. Chapter IV. 162-163.

Abstract - These two pages discuss the yew, or ground hemlock. Included are: quick identification check tips, description, occurrence, toxicity, treatment, and notes.

Antos, Joseph A.; Habeck, James R. 1981. Successional development in Abies grandis (Dougl.) Forbes Forests in the Swan Valley, western Montana. Northwest Science. 55(1): 26-39.

Abstract - Abies grandis is abundant and is potentially a climax species over a major part of the Swan Valley in western Montana. This area is among the easternmost extensions of wet, lowelevation forests related to the Pacific maritime climatic influence. Species coverage and site parameters were ascertained on 56 natural stands representing a wide range of site conditions and stand ages. The stand data were analyzed using polar ordination techniques. Site moisture status and successional development are the most important factors determining species composition among the Abies grandis forests studies. Few, if any, stands have reached climax status due to the repeated occurrence of fire. After intense fires, Larix occidentalis and Pinus contorta become established. When stands over 150 years old burn, Larix occidentalis tends to predominate in the regeneration; if the stands are young, Pinus contorta tends to be favored. Abies grandis typically forms a layer below the Larix occidentalis or Pinus contorta canopy. Tree compositional changes along synthesized developmental pathways and understory alterations are discussed.

Austermann, Kurt. 1992. Seed orchard cultivates Pacific yew. BLM News, Oregon and Washington. United States Department of the Interior, Bureau of Land Management. Oregon State Office. Portland, Or. January. P. 2.

Abstract - Researchers at the Bureau of Land Management's Charles A. Sprague Seed Orchard are attempting to propagate Pacific yew trees through seed stratification. The nursery currently has 300 seeds in storage. The Pacific yew has recently become a valuable resource because its bark has been found to contain taxol, a successful anticancer compound. 
Atzet, Thomas; Wheeler, David L. 1984. Preliminary plant associations of the Siskiyou Mountain province. USDA, Forest Service. Pacific Northwest Region.

Abstract - This publication is the first approximation of the plant associations in the Siskiyou Mountains and the result of the Area Five Ecological Program to classify Forest Service administered lands. It is a guide documenting the first of two phases of classification: floristic classification and description. (Phase two, the predictive phase, provides plant response information such as growth, yield, successional pathways, and potential productivity.)

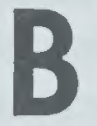

Bolsinger, Chuck. 1990. Material for a state-of-knowledge paper on Pacific yew (which is detailed in a paper to be published in the Silvics Manual). PNW-FIA.

Abstract - This information on the Pacific yew is presented in three categories: (1) distribution, abundance, and ecological setting of Pacific yew; (2) inventorying Pacific yew on National Forests - some considerations; and (3) conservation/ protection considerations. This paper also addresses an "apparent inconsistency" between Thomas Spies' paper on plant species diversity in old growth and FIA data that show yew to be present in 500,000 acres of young growth stands.

Bolsinger, Charles L.; Jaramillo, Annabelle E. 1990. Taxus Brevifolia Nutt. Pacific Yew. In: Silvics of Forest Trees of North America. R.M. Burns and B.H. Honkala, Tech. Coordinators. USDA Forest Service. Agricultural Handbook No. 654. Vol. 1, Conifers. Washington, DC. December: 573-579.

Abstract - Pacific yew, also called western yew, is a coniferous tree associated with several conifer and hardwood tree species on a variety of sites. Pacific yew tolerates shade, and in undisturbed stands is usually found as an understory tree. Growth of such trees is slow, but where the overstory has been removed or thinned, diameter growth on undamaged yew trees may increase considerably. Pacific yew rarely exceeds $60 \mathrm{~cm}$ (24 in) in d.b.h., and $15 \mathrm{~m}$ in height. The largest on record is $142 \mathrm{~cm}$ in d.b.h., and $18 \mathrm{~m}$ in height. The wood is hard, heavy, and resistant to decay. 
Although not of great interest to the forest products industry, it has many special uses. Because the bark of Pacific yew contains a drug, taxol, that is being used in cancer research, demand for yew bark by the National Cancer Institute has increased dramatically in recent years.

Borman, Stu. 1991. Scientists mobilize to increase supply of anticancer drug taxol. Chemical \& Engineering News. September 2: 11-18.

Abstract - This article first discusses a brief history of the discovery and development of taxol as a cancer fighting drug. Problems lie within the fact that the current source of taxol, the Pacific yew, is in limited supply. The author goes on to discuss alternative ways scientists are working to increase the supply of taxol. The French pharmaceutical firm, Rhone-Poulenc Rorer, is currently developing a taxol analog, taxotere. Taxotere begins with a taxol precursor isolated from yew needles. Another strategy being investigated to increase taxol availability is direct extraction of the compound itself from yew needles. Researchers at the Forest Service's Forest Products Laboratory at Madison, WI are studying extraction of taxol from the heartwood of the Pacific yew. Another possibility is obtaining taxol from Taxus plants grown for ornamental use instead of the wild. The concept of producing taxol in cultures of cells grown in bioreactors is also being investigated.

Brady, Timothy J. [1985 rev.] Field key to the conifers and taxads of British Columbia, Washington, Oregon, and northern California. Seattle, WA: Department of Botany. 1-7. Abstract - This guide provides, in outline form, descriptions of both conifers and taxads found in the Northwest. Included are (1) both scientific and common names and (2) descriptions of bark, leaves, and other identifiers. A glossary is also provided.

\section{Bristol-Myers Squibb Company. [n.d.] Taxol Q \& A. New} York, NY. 10 p.

Abstract - Several questions and answers regarding taxol are provided. These questions and answers are divided into five subheadings; Background/General Information, Research \& Development, Cooperative Agreements With The U.S. Government, Environment/Supply, and Alternative Sources. 
These questions and answers are provided by Bristol-Myers Squibb Company.

Bristol-Myers Squibb Company. [n.d.]. The search for alternative sources of taxol. New York, NY. 4 p.

Abstract - This paper discusses the most promising research leads which are expected to provide some relief from the need to use yew bark for taxol production within two to three years. One alternative, biomass, refers to the renewable parts of the yew, such as leaves and twigs. These parts would be used to extract taxol, though their yield would probably not be sufficient. Semi- and total synthesis is also being researched. In the future, taxol might be produced by extracting a taxol molecule from the leaves of readily available yew plants. Scientists are also working to produce taxol from the cells of fast-growing parts of the yew tree, "plant cell culture." Finally, the feasibility of developing yew plantations is being investigated. A timetable is also provided.

Brody, Jane E. 1990. Gardens of plant tissue in labs seen as factories for vital drugs. The New York Times, Science.

November 20.

Abstract - This article describes taxol, derived from the bark of the Pacific yew, as one of the most promising anticancer drugs to be tested in years. Due to the limited natural supply and futile synthesizing efforts, researchers have turned to tissue culture, reproducing in the laboratory bark cells that can produce large amounts of taxol. By manipulating plant cells and growing mediums, researchers can create vast laboratory gardens of plant parts that produce important chemicals quickly, cheaply and reliably in a confined space. The goal is to create a "forest" of bark from the Pacific yew without having to destroy a single tree.

Brown, H.P., et. al., 1949. Textbook of Wood Technology. 1st

Ed. New York: McGraw-Hill Book Co., Inc. p.506.

Abstract - Discusses uses of yew wood (poles, bows, canoe paddles, etc.). 
Byrnes, Patricia. 1991. Are we killing a cure for cancer? Wilderness. Summer. 54(193): 4.

Abstract - Conservation groups claim that the Forest Service and BLM are not properly managing the Pacific yew as a valuable resource. Until the Pacific yew was found to contain taxol, a promising new anticancer drug, the tree was considered worthless by foresters and timber companies. Yews were discarded as "weed" trees and left to burn on slash piles. Because yews exist mainly in the old growth forests of the Pacific Northwest, as little as 10 percent of the original stands may remain. The Wilderness Society has urged the Forest Service and BLM to create a special task force to deal with the Pacific yew controversy, and to create a viable and environmentally sound means of managing the trees. The Wilderness society is concerned that trees and taxol are being wasted because the federal agencies do not have a clear idea of how to manage the remaining stands of native Pacific yew.

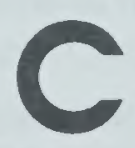

Calder, James A.; Taylor, Ron L. 1968. Flora of the Queen Charlotte Islands, Part 1: systematics of the vascular plants. Research Branch, Canada Department of Agriculture. Monograph No. 4 Part 1: 161-162, 558.

Abstract - Taxus brevifolia, found on Graham Island and Moresby Island of the Queen Charlotte Islands, is briefly described. A map is also provided, showing where Toxus brevifolia can be found.

Campbell, Robert K. 1979. Genecology of Douglas-fir in a watershed in the Oregon Cascades. Ecology. 60: 1036-1050. Abstract - To gain insight into genetic microstructure of subregional populations of coastal Douglas-fir, genetic variability in a population found on a 6100-ha central Oregon watershed is described. Genotypic values of 193 parent trees located throughout the watershed were estimated from progeny grown in a common garden. Then, genetic cariation was partitioned into components attributable to parent-tree location and to differences among trees within locations. Withinlocation variation appeared to be homogeneous in the watershed; depending on the trait measured. Although other 
possibilities exist, the topoclinal variations are due to high selection intensities in the seedling stage, the former to selection by average environmental differences along gradients, the latter to microenvironmental heterogeneity. The combination of high within- and between - habitat variation is suited to a species which episodically colonizes an environment that is extremely heterogeneous in time and space.

Cannon, Bill. 1992. The ugly sapling: wonder drug from trash tree? Columns. March: 20-23.

Abstract - This article describes an outing by University of Washington scientists to take study samples from the world's largest recorded Pacific yew tree, located on the Gifford Pinchot National Forest. The article also discusses yew natural history and some of the current issues surrounding yew trees and the cancer-fighting drug taxol. Until they were discovered to contain taxol, yew trees were considered to be "trash trees" by forest harvesters. Scientists are unsure as to how many yew trees may be harvested for taxol without destroying the species. Scientists hope to find new ways of extracting and producing taxol in order to minimize the need to use live trees. Heinz Floss, a chemistry professor at the University of Washington, is working under a $\$ 26,000$ grant from the American Canoer Society to biologically synthesize taxol. The article also includes a brief sidebar by Cheryl Dawes describing the University of Washington's "compassionate use" program, a taxol cancer treatment program for women whose ovarian cancer had not responded to at least three courses of chemotherapy.

Chadwick, L.C.; Keen, R.A. 1976. A study of the genus Taxus. Wooster, Ohio: Ohio Agricultural Research and Development Center.

Abstract - The taxonomony of the genus Taxus is controversial. The recognized species are more geographic than morphologic and many of the cultivars and clones in America have not been described or named by horticulturists in accord with the International Code of Nomenclature of Cultivated Plants (2). This publication aids in furnishing descriptive information of many of the cultivars now in the trade. It includes sections on propagation and culture. 
Chang, Ying-Pe. 1954. Bark structure of North American conifers. USDA, Forest Service. Technical Bulletin No. 1095. 86 p.

Abstract- This study, which was a 1951-52 project of the U.S. Forest Products Laboratory, dealt with the comparative anatomy of North American coniferous barks. Its general objectives were essentially the following: (1) To determine the basic anatomical structure of all tissues outside the cambium of matured barks; (2) to evaluate the features of bark structure of diagnostic value and other related findings from bark as means for identification of species; and (3) to induce the viewpoints that would correlate bark structure to related research in the field of forest products.

\section{Coley, Phyllis D.; Bryant, John P.; Chapin, F. Stuart-III.} 1985. Resource Availability and Plant Antiherbivore Defense. Science. 230(4728): 895-899.

Abstract- The degree of herbivory and the effectiveness of defenses varies widely among plant species. Resource availability in the environment is proposed as the major determinant of both the amount and type of plant defense. When resources are limited, plants with inherently slow growth are favored over those with fast growth rates; slow rates in turn favor large investments in antiherbivore defenses. Leaf lifetime, also determined by resource availability, affects the relative advantages of defenses with different turnover rates. Relative limitation of different resources also constrains the types of defenses. The proposals are compared with other theories on the evolution of plant defenses.

\section{Congress of the United States Office of Technology As-} sessment. 1991. Biotechnology in a Global Economy. October: 73-96.

Abstract - This report discusses the development of biotechnology-based pharmaceutical products. The report focuses mainly on the business aspect of biotechnology and the pharmaceutical industry. It is divided into four main sections, which include entries on research and development, biotechnology-derived drugs, and competitive factors. The biotechnology industry is proving to be quite important in the discovery of new drugs. Currently, the commercialization of biotechnology is highly dependent on market forces. 
Cordell, G.A. 1992. Novel strategies for the discovery of plant anticancer agents. Program for Collaborative Research in the Pharmaceutical Sciences, Chicago: Department of Medicinal Chemistry and Pharmacognosy, College of Pharmacy, University of Illinois at Chicago. 60612.

Abstract- Drug discovery involving plants has been a pursuit of mankind since prehistoric times. Through previous efforts, plants established as being a viable source of clinically useful compounds (e.g. vincristine), have afforded leads for synthetic modification (e.g. camptothecin) and have served as tools for mechanistic studies. In this presentation, some previous studies will be reviewed and a new strategy for the discovery of anticancer agents from plants will be described in which ethnomedical information is correlated with pertinent published chemical and biological information, resulting in a prioritization of plants for collection. Authenticated plants are extracted and the extracts tested in a broad cooperative research program involving a university, a research institute and a pharmaceutical company. Bioactivitydirected fractionation is carried out at all three sites, with a view to identifying novel compounds which may serve as candidates for preclinical testing.

\section{Cragg, Gordon M.; Boyd, Michael R.; Cardellina, John H.} [and others]. 1992. Role of Plants in the National Cancer Institute Drug Discovery and Development Program. Bethesda, MD: Developmental Therapeutics Program, National Cancer Institute (NCI). 20892.

Abstract- Over the past 30 years, NCI has developed a number of clinically active plant-derived drugs. Prior to 1986, collections were generally restricted to temperate areas of the world. Since then collections have focused on tropical (primarily rainforest) regions and over 27,000 samples have been collected from over 25 countries. Policies have been formulated aimed at establishing collaborations with scientists in these countries, and providing long-term compensation for drugs which are developed as marketable products. The various facets of the drug discovery and development program will be discussed, including future plans for the large-scale production of promising new anticancer and antiviral natural products (e.g. taxol and camptothecin derivatives). 
Crawford, Rex Charles. 1983. Pacific yew community ecology in north-central Idaho with implications to forest land management. Forest, Wildlife and Range Experiment Station: University of Idaho. 109 p. Ph.D. dissertation.

Abstract - Taxus brevifolia (Pacific yew) develops into dense stands in north-central Idaho, deviating from its usual occurrence as a scattered, small tree or shrub in mesic forests of the Pacific Northwest. Approximately 16,000 hectares of forest land in the South Fork of the Clearwater River basin Idaho are occupied by $T$. brevifolia communities. Twenty-seven mature, undisturbed $T$. brevifolia stands were surveyed for physiognomy, vascular floristic composition, species cover, tree population structure and physical soil characteristics. These stands were analyzed and compared with 26 adjacent undisturbed, mature Abies grandis communities. Analysis of tree population structure indicated that T. brevifolia is the climax dominant. It showed more success in self-replacement in the absence of major disturbance than any conifers. The $T$. brevifolia habitat type occurs on warmer sites with shallower soils than the Abies grandis habitat type. $T$. brevifolia trees survive logging operations and will adapt to unshaded conditions.

Crawford, Rex C.; Johnson, Frederick D. 1985. Pacific yew dominance in tall forests, a classification dilemma. Canadian Journal of Botany. 63: 592-602.

Abstract - A review and discussion of the confusing terminology for units designating variation in vegetation associations (habitat types) are presented. In portions of the northern Rocky Mountains, the short tree Taxus brevifolia is presented, concluding that associations and not phases are the appropriate interpretation. Binomials now used in forest classifications conceal information on community structure and composition. Trinomials are proposed.

Curtis, Cynthia; Bray, Anne, compilers. 1987. Boatbuilding woods: a directory of suppliers. Woodenboat Magazine.

Abstract - Boatbuilding woods available in the U.S. are listed by state and species sold by dealer. Several are listed for Oregon and Washington. 


\section{D}

Daly, Douglas. 1992. Tree of life. Audubon. March/April: 77-85.

Abstract - This article gives a general history of taxol discovery and supply; some yew natural history is discussed. Taxol, a compound found in the bark of the Pacific yew tree, has proven successful as an anticancer agent. Supply is short and cancer patients are desperate to receive the drug. The author comments on the irony of the situation. Until recently, the yew was thought by foresters to be a worthless "weed tree," and was often left to burn in slash piles after logging. The social, economic, and political impacts of taxol discovery and yew harvest are discussed. Two sidebars are included with the article. One gives a brief discussion on Canadian yew exports to the U.S. The other discusses the toxicity of taxol, and explains that often the difference between a cure and a poison is the dosage. Taxol does have side effects, some serious, which include bone-marrow toxicity, loss of white blood cells, aching muscles, hair loss, diarrhea, nausea, vomiting, and rarely, cardiac and central neuro-toxicity.

\section{Developmental Therapeutics Program, Division of Can- cer Treatment National Cancer Institute. 1990.}

Bethesda, MD: Workshop on taxol and Taxus: current and future perspectives. June 26.

Abstract - This volume includes abstracts of all speakers who presented at this workshop on taxol and Taxus. There is also a list of participants with their addresses and telephone numbers. The remainder of the book is broken down into six sections: Agronomics, Chemistry, Clinical Studies, Biological Production, Biological Effects, and R\&D Support. Each section includes "Taxol Workshop Information Sheets" which allow individuals to address their area of taxol interest, summary of current work and future plants, and areas in which they are seeking collaboration. 


\section{E}

Eblin, James B. 1991. The Yew and We. A paper prepared in partial fulfillment of the requirements for Professor Stark Ackerman's Forest Law and Policy Seminar, Lewis and Clark Northwestern School of Law. 24 p. Seminar Paper.

Abstract - This paper presents the history and background of various views on theyew/taxol controversy. While presenting and exploring ethical issues, Eblin provides an overview of Taxus brevifolia and the drug taxol. Eblin begins with an explanation of yew taxonomy and eventual classification in the family Taxales. He briefly delves into yew cultural background and also covers the evolution of taxol into a breakthrough cancer drug; the petition to list yew as a Threatened and Endangered species; the relationships between the National Cancer Institute, Bristol-Myers Squibb, Hauser, the Forest Service, and the Bureau of Land Management; alternative sources of taxol; the non-use of needles as a source; bark collection; and his prediction of the future and commentary on the present. Eblin forecasts that the Forest Service will allow harvest in HCAs based on a pattern of allowing the maximum productive utilization permitted under the rules.

Environmental Defense Fund. [n.d.]. Fact Sheet on the Pacific Yew (Taxus brevifolia). Washington, DC. 2 p.

Abstract - This fact sheet includes 15 short paragraphs with historical, technical, and statistical information about the Pacific yew and taxol. The Pacific yew is found to exist mainly in the old growth forests of the Pacific Northwest. The tree is an understory species, depending on cool, moist habitats. Much of the yew's habitat has been destroyed by clearcut logging operations. Neither the Forest Service nor the BLM currently treat the Pacific yew as a "sensitive" species. The bark of the yew contains an important cancer-fighting compound called taxol, found to be effective in treating ovarian and possibly several other types of cancer. The fact sheet goes on to suggest that the tree be listed as a threatened species under the Endangered Species Act. Federal listing would force the U.S. Fish and Wildlife Service to restrict commerce in the species. Listing the Pacific yew would ensure its survival as a species. 
Environmental Defense Fund. [n.d.]. EDF Fact Sheet.

Washington, DC. $1 \mathrm{p}$.

Abstract - This fact sheet on the Environmental Defense Fund is divided into four sections. They include: EDF at a Glance, EDF Goals, EDF Successes, and EDF Offices.

Environmental Defense Fund. 1990. Petition to Secretary Manuel Lujan. Washington, DC. September 19. 12 p.

Abstract - This petition sent to Interior Secretary Manuel Lujan requests the listing of the Pacific yew tree as a threatened species under the Endangered Species Act. The petition is signed by eight environmental groups and three scientists. The document cites four main reasons for listing the yew. They are as follows: I. "Because the Pacific yew occurs principally within ancient forests and those forests have declined substantially over the past century, the yew is today a depleted species." II. "The Pacific yew is extremely vulnerable to logging operations and is being further reduced with liquidation of the ancient forests." III. "It is imperative that the Pacific yew be afforded protection since it currently serves as the major source of the anticancer compound taxol, and it will enhance efforts to produce an alternative source of taxol." IV. "Addition of the Pacific yew to the list of threatened plant species will authorize federal agencies to protect the species from habitat destruction and commercial exploitation." The document is footnoted and referenced.

Environmental Defense Fund. [n.d.]. Some Questions and Answers. Washington, DC. 3 p.

Abstract - This question and answer sheet briefly discusses the Pacific yew as a source of taxol, a promising new anticancer compound. Two questions are addressed. The first relates to the consequences of listing the yew tree as a threatened species under the Endangered Species Act. The second discusses various other plant-derived pharmaceutical compounds and their contributions to society. A partial list of plantderived medicines currently in use is also included. 
Erikson, Deborah. 1991. Secret garden, cell culture may provide a unique route to taxol. Scientific American. October: 121-122.

Abstract - Taxol will not be useful as a widely used cancer drug until it is produced in mass quantities. Using the bark of the slow-growing Pacific yew tree is not a long-term solution. Scientists are attempting to make taxol from cultures of yew cells. The National Cancer Institute recently awarded a $\$ 1.27$ million grant to develop methods for mass production of taxol through cell culture. Scientists predict that a large scale tissue cell culture system will be working within the next two to three years. If cell culture proves successful, other botanical drugs may be produced in mass quantities.

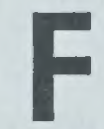

Fackelmann, Kathy A. 1992. The Adjuvant Advantage. Science News. February 22: 124-125.

Abstract - Women with early stages of breast cancer may increase their chances of survival by having adjuvant therapy, additional chemotherapy treatment after breast cancer surgery. Four studies published in 1989 by the New England Journal of Medicine indicate that women with early stages of breast cancer who receive adjuvant therapy are more likely to stay cancer-free for four years. Some physicians are skeptical about adjuvant therapy. They point out that the studies do not prove that a woman's long-term survival is improved, and that the often severe side effects of chemotherapy decrease quality of life. A statistical technique employed by Richard Peto, director of Oxford's Cancer Studies Unit, was used to project long-term survival rates among women with early stages of breast cancer who received adjuvant therapy. The resulting data suggested, among other things, that additional therapy following breast cancer surgery can increase a woman's life by 10 years. Taxol, a powerful anticancer drug extracted from the yew tree, is now being tested as an adjuvant therapy treatment. While taxol is known mainly for its ability to fight ovarian cancer, researchers say preliminary findings suggest that the drug may also help women with breast cancer. 
Farnsworth, N.R. 1992. The Importance of Plant-Derived Pharmaceuticals and Methods Used for Identifying Plants for Drug Discovery. Program for Collaborative Research in the Pharmaceutical Sciences, College of Pharmacy, University of Illinois at Chicago, Chicago, Illinois, 60612.

Abstract - This presentation will provide an overview of the importance of plant-derived pharmaceuticals in the USA and globally. More than 120 plant-derived compounds of known structure are currently used as drugs throughout the world. Many of these are not used in the USA, but are of established medical benefit. These 120 compounds are derived from only 90 species of plants, most from temperate zones of the world and $74 \%$ of them were discovered by chemists who were attempting to isolate and identify the active principles of the plants based on folkloric (ethnomedical) uses. The value of ethnomedical information as a predictor of experimental biological activity will be examined and other methods of selecting plants for specific biological activities will be delineated. Some examples of plant-derived bioactive compounds that have provided new "unnatural" drugs based on analog preparation will be presented. Considering that more than 250,000 species of higher plants exist on this planet, more rational approaches than blind screening after random collection of plants seem to be worthy of using.

Fiscus, James W.; McMahon, Donna. 1991. Medical science races to increase output of taxol. Portland: The Oregonian. November [n.d.]. Section B.

Abstract - This article discusses efforts by scientists to synthesize taxol, with an eye toward full clinical use. Taxol is currently used in large-scale phase III trials for the treatment of ovarian cancer and has been made available to 39 U.S. cancer treatment centers for care of women with epithelial ovarian cancer. There is concern that public expectations for taxol may be too high, and that the drug has been oversold. Taxol is in short supply, and this has slowed research. When taxol is accepted for general clinical use, far larger supplies will be needed. An analogue of taxol, taxotere, in which the 
side chain is added to baccatin III extracted from the European yew is being tested in the United States and in France. Baccatin III is extracted from leaves while taxol is extracted from bark. ESCAgenetics Corp. is working to produce taxol from tissue cultures.

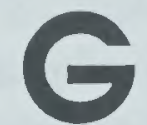

Green, Pat ; Ward, Roger. 1991. Yew Sprout Assessment, Nez Perce National Forest, Idaho. Report on file with yew technical committee. Portland, OR: USDA Forest Service, Pacific Northwest Region, Portland, OR. 1 p.

Abstract -Green and Ward conclude from their observations that sprouting is moderately reliable from stumps of yew unaffected by fire. However, under the browse regime on the $\mathrm{Nez}$ Perce, there is no indication that sprouts will do more than maintain a precarious viability for the plant, with little hope of recovering reproductive capacity. Tree form yew that is above browse height seems to be the primary agent for sexual reproduction, and current levels of browsing on smaller yew suggests that moose population pressure will prevent smaller yew from growing out of browse height. It looks like significant if temporary declines in moose populations would be required to allow new yew plants to develop the tree-like form that is useful for bark harvest.

Greenup, Mel. 1992. Personal Communication. Port-Orfordcedar, Pacific yew, and fungus Phytophthora lateralis. March $9.1 \mathrm{p}$.

Abstract - Phytophthora lateralis, a fungus normally associated with Port-Orford-cedar has been found on Pacific yew trees in a small area of the Siskiyou and Six Rivers National Forests. Yew trees infected with the fungus were found only in areas where they were mixed with infected Port-Orfordcedar, although the Pacific yew trees appear to be more variable in their susceptibility to infection. Any yew trees found to be infected are being mapped and monitored. All yew inventory crews in Regions 5 and 6 will be briefed on how to identify the fungus. Disease control strategies will be developed for yew trees. 
Gunther, Erna. 1945. Ethnobotany of Western Washington. Seattle: University of Washington Press. P. 16.

Abstract - This text on Native American use and knowledge of indigenous plants includes an entry on Western yew. This tree was used by at least eight Pacific Northwest Indian tribes for various purposes. The Klallam, Samish, and Swinomish dried yew needles and used them as a tobacco substitute for smoking. Many tribes used yew wood for constructing bows, arrows and other weapons. Yew was also used as a medicine. The tree symbolized strength and power. Swinomish youths would rub themselves with yew sticks and boughs to impart strength. The Chehalis soaked crushed yew leaves in water and bathed children and elderly persons in it. The Klallam used yew leaves to make a tea, which they drank to heal internal ailments and injuries. The Quinalt made a tea out of dried, peeled yew bark, which was ingested as a lung medicine.

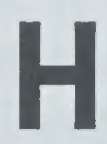

Hall, Frederick C. 1989. Plant association and management guide for the Ochoco and southern Blue Mountain areas. United States Department of Agriculture, Forest Service, Pacific Northwest Region, R6 Ecol TP-000-90.

Abstract - This guide provides information on vegetation in both forest and non-forest settings in the Ochoco and southern Blue Mountain areas. A key is provided to be applicable to vegetation in most stages of disturbance such as poor and very poor forage rating, clearcuts, and burns. Plant association descriptions are organized by similarity in dominant plants and environment. A species list is included, alphabetized both by Genus and common name. Summary tables are provided concerning the non-forest environments, forest productivity, tree species productivity. Also shown is an association table. Finally, an "indicator species" section is divided into dryland vegetation and wetland vegetation. 
Hall, Judy; Alaback, Paul. [n.d.]. Native plants of southern Alaska. University of Alaska Press. [only have 1 page].

Abstract - The included page provides a brief description of Taxus brevifolia, the Western yew. Locations where the yew can be found, as well as a few comments are also shown.

Hartzell, Hal. 1991. The yew tree - A thousand whispers. (Biography of a Species.) Hulogosi Press. 319 p.

Abstract - Originally written about the myth, legend, lore, historical, and poetical associations of the yew tree in 1983, this book was rewritten to include several chapters about the taxol issue, as well as additional mythical and poetical allusions, and historical, geographical, and botanical information. It includes an afterword by Jerry Rust, and three appendices listing: yew trees larger than 20 feet in girth in England and Wales; notable topiary and hedges in England; and yew species and cultivars.

Hauser Northwest, Inc. [n.d.]. Pacific yew bark for cancer research and treatment [Brochure]. Cottage Grove, OR. Abstract - This brochure briefly discusses the Pacific yew as the source of the new cancer drug, taxol. The National Cancer Institute is working jointly with Bristol-Myers Squibb Company to develop this drug. Because of their success at developing other medically valuable drugs from natural substances, Hauser Chemical Research, Inc. has been selected as the supplier of yew bark and taxol. Current taxol collecting techniques and developments are also discussed.

Heiken, Doug. 1992. Federal management of an emerging resource: the Pacific yew. Unpublished. Draft. January. 87 p.

Abstract - This paper discusses the need to balance federal management of the Pacific yew with creating a sustainable yew management program. The paper critically analyzes the response of federal agencies to the discovery of yew as a valuable resource on federal lands. The paper is divided into thirteen sections which include discussions on yew in history, occurrence and ecological function of the Pacific yew, supplying the anticipated future demand for taxol, the role of the National Cancer Institute and the Food and Drug Adminis- 
tration in developing and approving taxol, USDA Forest Service management program for yew, Bureau of Land Management yew program, environmental impact analysis and citizen participation under the National Environmental Policy Act, recent congressional action of the Pacific yew, pending litigation on waste of Pacific yew resources, and poaching of yew bark from federal lands.

High Country News. 1991. Drug firm gets a monopoly on harvesting yew trees. August 26.

Abstract - The Forest Service and Bureau of Land Management have signed agreements with Bristol-Myers Squibb giving the pharmaceutical giant first rights to all Pacific yew trees (needed for extraction of taxol) on federal lands for at least five years. In exchange, the drug company will fund an inventory of the trees on federal lands, develop yew conservation guidelines, and conduct research toward the establishment of yew plantations. A current issue is that the old growth where most Pacific yews are found will be destroyed in the search for the drug. The drug company plans to extract taxol from yew needles and other sources eventually, but for the time being, yew bark is the only source of the drug.

Hoadley, R. Bruce. 1990. Identifying wood: accurate results with simple tools. The Taunton Press. Newtown, CT. 223 p. Abstract - Pacific yew (T. brevifolia) wood is easily distinguishable from other woods. Its texture is extremely fine with orange to russet heartwood. Pacific yew is indistinguishable from that of European or common yew.

Holmes, John. 1991. Trying to save a lifesaver. Insight. 7(36): 30-31.

Abstract - This article discusses the controversy taking place in the forests of the Pacific Northwest. The Pacific yew tree is the source of a new cancer-fighting drug called taxol. The drug is found in the bark of the yew. Environmentalists fear that the sudden demand for yew trees and taxol will destroy the species. Although scientists are close to synthesizing taxol in the laboratory, conservation groups worry that the tree will be wiped out before synthesis is perfected. 
Horwitz, Susan B. 1992. Taxol: mechanisms of action and resistance. Department of Molecular Pharmacology. Bronx, NY: Albert Einstein College of Medicine.

Abstract - Taxol is emerging as a drug that is very likely to play a major role in cancer chemotherapy in the future. It is demonstrating extremely encouraging activity in human advanced ovarian cancer and metastatic breast carcinoma. The drug is isolated from the bark of Taxus brevifolia, the western yew, which is a slow growing evergreen species found in the ancient forests of the Pacific northwest. In addition to having a novel chemical structure, taxol has a unique mechanism of action. The drug induces the formation of cytoplasmic bundles of microtubules in cells and stabilizes the microtubule polymer against depolymerization. A murine tumor cell line, J774.2, selected for resistance to taxol, displays the multidrug resistance phenotype including the overproduction of $\mathrm{P}$ glycoprotein, a drug-efflux pump responsible for maintaining low levels of taxol within the resistant cells. Compared to the parental drug-sensitive cell line, the taxol-resistant cell line also synthesizes increased quantities of tubulin, the subunits of microtubules.

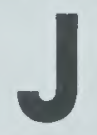

Jaffe, Mark. 1992. Killing the cure. The Philadelphia Inquirer Magazine. February 23: 16-24.

Abstract - The old growth forests of the Pacific Northwest provide the backdrop for this article, which discusses the Pacific yew tree as the main source of the cancer-fighting drug, taxol. The author gives a comprehensive history of taxol discovery and research, from the early 1960's when it was first discovered, to the present. A U.S. Department of Agriculture botanist first identified taxol in 1962 while working with the National Cancer Institute in a combined-effort search for natural anticancer drugs. Taxol did not get much widespread attention until 1978 when researchers realized that it did not behave like other cancer-fighting drugs. Instead of stopping cell division by blocking the growth of microtubules, small hollow tubes that give cells shape and are essential for cell division, taxol actually increases microtubule production. This 
results in the cancer cell actually being trapped within its own structure, unable to divide and grow. The author goes on to discuss the ways in which the fate of the Pacific yew and other plants containing life-saving medicines are ultimately tied to the fates of their respective ecosystems.

Jagels, Richard. 1986. Woods of the West. Woodenboat. Jan/ Feb. No. 68: 103-104.

Abstract - Mentions that Taxus brevifolia is a good boat wood and is available along the British Columbia Coast.

Jagels, Richard. 1981. Under-utilized boatbuilding woods.

Woodenboat. [Wood Technology Column]. Nov/Dec. No. 42: 123-124.

Abstract - The wood is hard, heavy, and strong, although it has a tendency toward brittleness. It is exceptionally decay resistant. Indians once used this wood extensively for everything from baskets to canoe paddles. Trees are becoming scarce and the wood is often difficult to obtain.

Junod, Tom. 1992. Tree of hope. Life Magazine. May: 71-76.

Abstract - This article discusses the history of taxol discovery and its use as an anticancer drug. Much of the article is told through the eyes of a cancer patient who received taxol. Because of limited supply, researchers currently are testing the drug only on patients with severe cases of ovarian cancer. For many, taxol is the last hope. The article also points out that while clinical trials have shown promise, taxol is not a cancer cure.

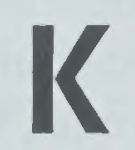

Kirk, Ruth. 1986. Tradition and change on the Northwest coast. British Columbia Provincial Museum. Seattle: University of Washington Press. 256 p.

Abstract - The weight and strength of yew made it suitable for clubs, bows, and the swordlike beaters that the weavers used to prepare wool. To kill a whale, men paddled alongside their prey and struck with toggling mussel-shell harpoon heads mounted on heavy shafts of yew 10 to 15 feet long. 
Klinger, David. 1991. Threatened designation inappropriate for Pacific yew; Fish and Wildlife Service cites abundance, few threats. News Brief. United States Fish \& Wildlife Service - Region 1. January 9.

Abstract - Insufficient scientific information currently exists to indicate the Pacific yew warrants listing by the Federal Government as a threatened species. The U.S. Fish and Wildlife Service noted further that existing data strongly suggest that listing is not warranted. The decision of January 9, 1991, which incorporates an administrative finding signed in Washington, DC means that the Interior Department agency will not pursue listing of the species at this time.

Krucoff, Carol. 1991. Unlocking the secrets of taxol. Saturday Evening Post. Sept/Oct: 46-47.

Abstract - Dr. Robert Holton, a chemist at Florida State University, has been successful in recreating taxol through a semi-synthetic process. The process involves joining a taxol precursor, Baccatin III, with an easily-synthesized side chain. Holton says, "Nothing is won until taxol's out there and available to patients. The big question now is how do you get large quantities of Baccatin III?" He and other scientists are currently working to synthesize Baccatin III, but for now he says the hundreds of varieties of yew are more likely to be the best source. This article also describes taxol's unique mechanism of action.

Kuehne, Gus. 1991. High Quality Forestry Alternative for Management of the Olympic and Mt. Baker-Snoqualmie National Forests in Washington State. Northwest Independent Forest Manufacturers. Tacoma, Washington. April 16.5 p.

Abstract - This paper focuses on the concept of High Quality Forestry (H.Q.F.), a proposed system of forest management. Under H.Q.F. management, forest harvest rotations would vary according to habitat needs, economic factors, aesthetic values, recreational uses, and water quality. The paper is divided into seven parts as follows: I. Introduction II. Current Situation III. The Timber Management/Old Growth Habitat Conflict IV. High Quality Forestry Concept V. Reforestation Cuts VI. Intermediate Cuts VII. Summary. 


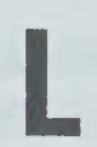

Leary, Warren E. [1991] FDA is planning to speed process of approving drugs. New York Times. November 13.

Abstract - The Food and Drug Administration announced plans to speed its drug approval process, including using outside experts to review new drugs and cooperating with other nations to standardize testing and regulation. These plans will hopefully revitalize the agency and "accelerate the availability of drugs for serious and life-threatening illnesses."

Ledig, F. Thomas. 1988. The conservation of diversity in forest trees - why and how should genes be conserved? Bioscience. 38(7): 471-479.

Abstract - This article outlines the scope of gene conservation in relation to wild plants and, most particularly, forest trees. Ledig addresses economic, ecological, and esthetic issues in relationship to gene conservation on an international level. Ledig maintains that breeding has not yet resulted in dangerous uniformity in forestry because most tree breeders strongly emphasize the maintenance of variability (Zobel, 1978). It is important to preserve all genes because it is impossible to predict what may be useful in the future. This takes on special importance now that genes can be transferred between virtually any organisms using recombinant DNA technology. The United States is a great exporter of genes; genetic resources are important to the economy of other countries. Measures that both conserve resources and provide economic benefits can forestall the collapse of our natural ecosystems and buy the world precious time to attack the root of the conservation problem-population growth and concomitant poverty.

Lemonick, Michael D. 1991. Whose woods are these? Time. December 9: 70 - 75.

Abstract - This article discusses the fate of the old growth forests. The author states that the national forests by definition belong to the American public, and it is the public, not industry lobbyists or agency bureaucrats, that should decide their fate. With increasingly concerned managers inside the 
Forest Service, environmentalists on the outside and legislators looking sharply over the agency's shoulder, there is reason to hope that the last stands of ancient trees will remain uncut-and that some of their younger cousins will eventually achieve the status of old growth themselves.

Little, Elbert. (Geographer). [n.d.]. Yew Range Map. Distribution of important forest trees of U.S. Volume 1. Map 86-w. 1:200, 1:400.

Abstract - This map shows the range of the native Pacific yew (Taxus brevifolia) as it is found from northern California to southeastern Alaska and east to Idaho and western Montana.

\section{M}

McCune, Bruce; Allen, T.F.H. 1985. Forest dynamics in the Bitterroot Canyons, Montana. Canadian Journal of Botany. 63: 377-383.

Abstract - Both shade-tolerant and shade-intolerant tree species may dominate young stands in canyon-bottom forests of the Bitterroot Range. Subsequent dynamics depend on growth characteristics of the colonizing species. Thus, much of the compositional variation arises at stand establishment rather than through a replacement process. Pacific yew, however, may require shelter from other species for establishment. Vertical similarity increases with stand age towards a maximum value of about $75 \%$. Although the importance of Pacific yew tends to increase with stand age, convergence on a common climax composition is thwarted by insularity of the canyon bottoms and an average fire cycle that is shorter than the normal longevity of the shortest lived major tree species.

McCune, Bruce; Allen, T.F.H. 1985. Will similar forests develop on similar sites? Canadian Journal of Botany. 63: 367-376

Abstract - This paper discusses the development of old growth mesic forests of the Bitterroot Canyons, western Montana, which tend to be dominated by Abies grandis, Taxus brevifolia, and Thuja plicata. The paper concludes that similar sites do not necessarily develop similar, relatively stable forests. 
Differences between site factors and historical factors are discussed. Site factors are defined as factors which are measurable on a specific site during the span of a typical research project. Historical factors are defined as factors which include rarely repeated circumstantial events. Based on the hypothesis, the authors advise caution in using climax vegetation as a standard for comparisons resting upon the assumption that climax composition is determined solely by site characteristics.

Miller, Charles N., Jr. 1988. The origin of modern conifer families. In: Beck, Charles B., ed. Origin and evolution of gymnosperms. New York: Columbia University Press: 448486.

Abstract - The object of the paper is to provide a synthesis of paleobotanical evidence concerning the origin of modern conifer families. Over 100 equally parsimonious trees resulted from the parsimony analysis of data. Despite evidence of homoplasy in many of the characters, there is only one basic form to the trees. Tree variations are due to differences in character state transitions and rearrangements of taxa within the Cupressaceae-Taxodiacea clade. Only two instances of character state reversal or parallelism occur in the equally parsimonious trees leading to the main clades, and only three instances of reversal or parallelism occur within the Araucariaceae- Cephalotaxacea-Pinacceae-Podocarpacceae clade. Thus, the broad trends indicated by the characters have phylogenetic significance at the family level but not at the genus level within the Cupressaceae-Taxodiaceae clade. Character state transitions are given for the family level clades only.

Murray, Marshall D. 1991. The tree that fights cancer. American Forests. July/August: 52-54, 70.

Abstract - Previously considered to be a worthless "weed tree" by timber harvesters, the Pacific yew has recently been discovered to contain an important anticancer drug. The compound, called taxol, is found in the bark of the slow-growing yew, which is most abundant in the old growth forests of the Pacific Northwest. While scientists are trying to develop 
alternative means of producing taxol, the bark of the Pacific yew continues to be the most viable source. Demand for the drug is rising, and environmentalists fear that the species will be destroyed by overharvest.

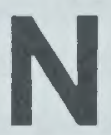

Nalder, Eric. 1991. Huge firm gets monopoly on promising drug. The Yakima Herald-Republic. December 26: 5C. Abstract - Under the Drug Orphan Act Bristol-Myers Squibb was given exclusive rights to market taxol for ovarian cancer for seven years. This news article discusses the reasons the government granted a near-monopoly to Bristol-Myers Squibb for the marketing of the drug taxol. Critics say development of the drug has taken much longer than it needed to and cut out competitors who could have done something about the short supply. Concerns about potential unfair pricing once taxol is approved for commercial use are also discussed.

Nalder, Eric. 1991. Late start, rigid bureaucracy delay production. Yakima Herald-Republic. December 27: 7A.

Abstract -This news article is about the search for alternatives to yew bark as a source for taxol. In spite of suggestions years ago from a botanist and other people involved in taxol, the search for alternatives was delayed for several reasons outlined in this article.

National Cancer Institute. 1991. Taxol briefing questions and answers.

Abstract - This is a list of twenty questions and answers regarding taxol, compiled by the National Cancer Institute. These questions generally cover the basic issues surrounding taxol, agreements with Bristol-Myers Squibb, and current research.

Norse, Elliott A. [n.d.] Statement. Washington, DC: Center for Marine Conservation. $3 \mathrm{p}$.

Abstract - In this brief statement, Dr. Elliott A. Norse, chief scientist at the Center for Marine Conservation, discusses the Pacific yew as an example warranting both "hope and warn- 
ing." Norse states that the depletion of the Pacific yew in clear-cut logging operations is a warning that we are depleting life on the planet and limiting biological diversity. The fact that the yew has only recently been found to contain the cancer-fighting drug taxol is testament to our ignorance of the many plant-derived medicines yet to be discovered. The overall message of Norse's statement is, "Saving biological diversity is saving human lives."

\section{Northwest Independent Forest Manufacturers. [n.d.]}

Timber harvest program for high quality forestry alternative, harvest schedules, stumpage prices, yields and quality for 150 and 200-year rotations. $17 \mathrm{p}$.

Abstract - This paper discusses High Quality Forestry (H.Q.F.) an alternative means of forest management. The paper is intended to give direction to the development of H.Q.F. and to evaluate the "price, quantity, and quality of timber harvested under the High Quality Forestry alternative." The paper is divided into 10 sections as follows: I. Introduction; II. Rotational Length; III. Commercial Thinning Schedules; IV. Pruning; V. Stumpage Prices for Regeneration Harvests; VI. Stumpage Prices for Commercial Thinnings; VII. Size and Quality; VIII. Total Yield Comparison for 100, 150 and 200 year Rotations; IX. Logging Systems; and X. Summary. Also included are six tables illustrating information on commercial thinning and stumpage prices.

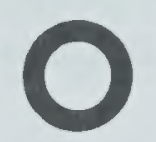

Onat, Astrida; Blukis, R.; Hollenbeck, J.L., ed. 1981. Inventory of Native American religious use, practices, localities, and resources. Seattle: Mt. Baker Snoqualmie National Forest.

Abstract -Yew was used to make bows and spear shafts; a tea was made (by Samish) from the needles to treat arthritis. Yew was used by the Tulalip Tribes to carve the miniature paddles worn on some ceremonial shirts and to make scoring sticks for bone games. The Cowlitz, Nisqually, Puyallup, and Muckleshoot also used yew. 
Oregon Association of Nurserymen, Inc. 1991-1992. Directory and buyer's Guide. Conifers, Taxus: 134-135.

Abstract - This publication includes a two-page listing of Oregon nurseries that sell various species of yew trees. Twelve different species are listed.

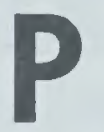

Pennisi, Elizabeth. 1991. Beyond yew: chemists boost taxol yield. Science News. 141: 244.

Abstract - Pennisi attended taxol workshops at the International meeting of the American Chemical Society in San Francisco and listened to scientists present their latest findings. This article briefly discusses advances leading to taxol from other sources which may yield better taxol-based drugs. Paul A. Wender, organic chemist at Stanford University, uses pinene from an inexpensive pine extract found in turpentine to construct a greater part of the taxol molecule. Jeffrey Winkler, a chemist at University of Pennsylvania does the same with a cedar extract. Pierre Potier, chemist at the Institute of Chemistry of Natural Substances in France, uses a European yew taxol precursor to create Taxotere. Robert A. Holton of Florida State University has improved a semisynthetic process using a compound from European yew leaves. Walter E. Goldstein with ESCAgenetics Corp. in California reports that plant cell cultures are another avenue for taxol supplies. All agree that taxol is a crude beginning for a new class of cancer drugs.

Perry, Patrick. 1991. Speaking out_cancer-fighting taxol, yew can do it. Saturday Evening Post. Sept/Oct.

Abstract - This article discusses the potential for a taxol supply from ornamental yew. Baccatin III, a taxol precursor, is found in high concentrations in the English yew, although it is present in varying degrees in all yews. Dr. Ed Croom, an economic botanist and key researcher at the University of Mississippi says scientific reports show some American ornamental yews show significant amounts of taxol comparable to that found in the bark of the wild Pacific yew. Clippings offer a renewable, abundant source of supply. He also comments 
on the difficulty of harvesting needles from wild yew in comparison to trimming yew needles in organized fields and affirms, "What we are really trying to do is develop a renewable, abundant, and economical source of the drug."

Pierce, John D; Peek, James M. 1984. Moose habitat use and selection patterns in north-central Idaho. Journal of Wildlife Management. 48(4): 1335-1343.

Abstract - Twelve radio-collared moose were monitored in north-central Idaho from January 1979 through April 1982. Moose selected vegetative types where forage was abundant in all seasons. old growth grand fir/ Pacific yew stands were critical moose winter habitat. Winter habitat use patterns did not differ among years even though snowfall varied dramatically. Even-aged pole timber stands and open areas, including clear-cuts and lakes, were used most by moose during summer. During deep snow periods, preferred moose habitat was characterized by dense cover and abundant forage.

Plenert, Marvin L. 1990. Memorandum on administrative 90day petition finding for the Pacific yew (Taxus brevifolia). United States Department of the Interior, Fish and Wildlife Service. December 21. 10 p.

Abstract - This memorandum constitutes the 90-day finding for the petition, in accordance with Section 4(b) 3(a) of the Act. This finding was prepared by the staff of the Sacramento Field Station and reviewed by the Portland Regional Office. The Service responded to each of the main points of the petitioners.

Polsky, B. 1991. Satellite images assist drug makers in cancer quest. Space News. October 28-November 3.

Abstract - Pacific Meridian Resources, a natural resources consulting firm, is helping the USDA to locate Pacific yew trees on public lands. Under a contract with the Forest Service, the company is using Landsat remote sensing devices to identify places where yew trees are likely to be found. The remote sensing satellites are owned and operated by the National Oceanic and Atmospheric Administration. The data collected is used to make maps. 
Potier, P.; Gueritte-Voegelein, D. 1992. Taxotere: discovery, structural studies and uses. Guenard Institut de Chimie des Substances Naturelles. CNRS-91198 Gif sur Tvette-France.

Abstract - Taxoterer is a new synthetic analogue of taxol which was selected on the basis of its enhanced inhibition of cold disassembly of microtubules compared to taxol. Now in phase II clinical trials, Taxotere $r$ is prepared from 10-deacetyl baccatin III, a compound isolated from the needles of the European yew tree (Taxus baccata L.). Taxol can also be easily prepared from the same naturally occurring compound. The production of taxane derivatives following this process is only limited by the accessibility of yew tree leaves. This process constitutes a much more interesting and ecological approach than that consisting in extracting taxol from the trunk bark which requires destruction of entire yew forests. From the same precursor a number of analogues have been prepared. Comparison of the conformations obtained by molecular modelization and NMR experiments on these different derivatives allowed us to determine the most likely "active" conformation. At present time, Taxoterer, is the best compound of the taxol series in the clinic owing to its better solubility and bioavailability.

Price, Robert A. 1990. The genera of Taxacacea in the southeastern United States. Journal of the Arnold Arboretum. 71: 69-91.

Abstract - This paper gives a technical overview of the genera Taxacacea (yew) as it is found in the southeastern United States. Plant morphology, range, natural history, and plant chemistry are discussed.

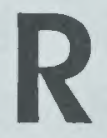

Richardson, Sherri. 1991. Pacific yew: a miracle cancer cure? Forestry Research West. April: 11-15.

Abstract - This article identifies the Pacific yew as the source of a life-saving drug, taxol. The Pacific yew is an understory species found along the Pacific coast from Alaska to central California, and is characterized by its relatively slow growth. One tree, on the average, provides 40 pounds of green bark 
that, when dried, weighs 19 pounds. 60,000 pounds of dried bark produces about nine pounds of taxol. Long-term viability of the species may still be a problem, especially where extensive areas of forest are managed on short-rotations and harvested by clearcutting. Attempts to synthesize taxol in the laboratory have not been successful. Many people believe it may not be possible. The USDA is also in the process of filing a patent to produce taxol from tissue cultures.

Robbins, C.T; Mole, S; Hagerman, A.E; Hanley, T.A. 1987.

Role of tannins in defending plants against ruminants: reduction in dry matter digestion. Ecology. 68(6): 16061615.

Abstract - Polyphenolic allelochemicals, such as tannins, are widely thought to reduce the digestibility of plants consumed by herbivores by binding to digestive enzymes and dietary proteins. While the apparent digestibility of protein and, therefore, cell soubles is reduced in mule deer and whitetailed deer consuming tanniferous forages, digestion of the plant cell wall is not reduced beyond that predicted from its content of lignin, cutin, and silica. The occurrence of such proteins in ruminants is reported here for the first time. The saliva composition of mule deer and domestic cattle and sheep are compared, and the higher potential of the deer saliva to neutralize tannins may minimize fecal nitrogen losses by maximizing the efficiency of tannin-binding per unit of protein and may reduce the absorption of hydrolyzable.

\section{Rowinsky, Eric K.; Cazenave, Lorraine A.; Donehower,}

Ross C. 1990. Taxol: a novel investigational anti-microtubule agent. Journal of the National Cancer Institute. 82(15): 1247-1259.

Abstract - Microtubules are among the most strategic subcellular targets of anticancer chemotherapeutics. Despite this, new anti-microtubule agents have not been introduced over the last several decades - until taxol. Taxol induces tubulin polymerization and forms extremely stable and nonfunctional microtubules. Taxol has demonstrated broad activity in preclinical screening studies, and anti-neoplastic activity has been observed in several classically refractory tumors (including phase II cisplatin-resistant ovarian carcinoma and phase 
I malignant melanoma and non-small cell lung carcinoma). Taxol's structural complexity has hampered the development of feasible processes for synthesis. Its scarcity has limited the use of a broad-scale screening approach. Taxol's unique mechanism of action, its pre-clinical anti-tumor activity, and tumor responses in early clinical trials have generated renewed interested in pursuing its development.

Rowinsky, Eric K; Donehower, Ross C. 1991. Taxol: twenty years later, the story unfolds. Journal of the National Cancer Institute. 83(24): 1778-1781.

Abstract - This editorial makes the case that the value of taxol to cancer patients and to society as a whole overshadows all negative aspects of the process that has led to taxol discovery and production. The authors state that while governmental involvement in a process that promises great potential for commercial value may be viewed critically by some, it is a small price to pay for the development of such an important drug. "The preliminary and extremely enoouraging success with taxol should also serve as an inspiration to those involved in drug development to be perseverant and tenacious..."

Rust, Jerry. 1991. The yew - a renewable economic resource for the Pacific Northwest. Presented to the Native Yew Conservation Committee. January 18.

Abstract - The yew tree and its derivatives, most notably taxol, represent an opportunity for sustainable economic development in the Pacific Northwest. This paper outlines an approach to develop a multi-faceted industry niche based on the yew, and will attempt to identify specific actions that could lead to the establishment of several thousand jobs and guarantee a renewable source of the promising anticancer treatment utilizing taxol. The approach suggested in this paper suggests conserving and utilizing the existing native yew stands on a sustained yield basis. Jobs would be created in bark and foliage collection; extraction of taxol; research and development; and forest conservation. Further job opportunities exist in developing a wood product line for finished yew products and in stimulating tourism and other forms of economic development. 


\section{S}

Schepartz, Saul A., Ph.D. 1991. Yews \& taxol: issues surrounding a new lifeline for cancer patients, guest column. NIH/OCC. Unknown Source: 3-4.

Abstract - This is an authoritative description of taxol and the scientific basis for encouraging its development. Taxol was isolated from the Pacific Yew tree. The problem is procurement of adequate quantities of the drug. The current source of taxol is the bark of the Pacific yew. It is imperative that alternative and renewable sources of the drug be developed to ensure species preservation due to the logistical and technical problems involved in collecting and processing large quantities of bark. The major emphasis in developing alternatives will be on production of taxol from the needles of Pacificyew and/or other Taxus species. Chemical stability of the compound in the needles is highly dependent upon the method of drying, which is not the case with the bark. Other approaches are also being investigated.

Scher, Stanley. [n.d.]. Conserving the Pacific yew. Fremontia. 19(4): 15-18.

Abstract - This article discusses the range of various species of yew, including Florida yew and Mexican yew. The author also discusses current threats to yew populations, yew conservation and management, and future yew management strategies.

Scher, Stanley; Jimerson, Thomas M. 1989. Does fire regime determine the distribution of Pacific yew in forested watersheds? General Technical Report, United States Department of Agriculture, Forest Service, PSW-109: 160-161.

Abstract - This article defines the habitat of the Taxus brevifolia and assesses the role of fire in limiting the distribution of this heat-sensitive species. Studies of TABR distribution in more than 950 plots suggest that proximity to water, vegetative cover, slope position, and elevation are major determinants of TABR on the Six Rivers and Klamath National Forests in northern California. Areas with high frequencies of fire have low frequencies of TABR occurrence. 
Scher, Stanley; Jimerson, Thomas M. 1989. Unpublished. Factors influencing the distribution of Pacific yew in northwest California. $27 \mathrm{p}$.

Abstract - Factors determining the distribution of Pacificyew were assessed on the Six Rivers and Klamath National Forests in northwestern California. Study sites included late, mature, and early seral stages of the major conifer series within the study area. Of the 951 plots surveyed, 143 contained Pacific yew. This species occurred most frequently in late seral stage stands of the PortOrford-cedar series (20 percent) followed by the Douglas-fir series (13 percent) white fir/red fir series (4 percent) and the Douglas-fir plantations (2 percent). Significant differences in stand age were noted for stands with and without Pacific yew in the Douglas-fir, white and red fir series. The primary factors influencing Pacific yew distribution were: stand age, fire frequency, slope position, slope shape, proximity to water, available water holding capacity, and conifer series.

Scher, Stanley; Schwarzschild, Bert. 1989. Pacific yew: a facultative riparian conifer with an uncertain future. General Technical Report. United States Department of Agriculture, Forest Service. PSW-110: 172-175.

Abstract - Increasing demands for Pacific yew bark, the source of an anticancer agent, have generated interest in defining the yew resource and in exploring strategies to conserve this species. The distribution, riparian requirements and ecosystem functions of yew populations in coastal and inland forests of northern California are outlined and alternative approaches to conserving this resource are identified. Efforts to obtain additional information on genetic diversity of yew populations and to ensure careful management of the species are essential for the protection of this resource.

Schweitzer, Robert, M.D. 1990. Letter to Secretary Manuel Lujan. American Cancer Society. September 19.1 p.

Abstract - This letter urges Interior Secretary Manuel Lujan to take "any and all" actions to protect the Pacific yew tree as a threatened species under the Endangered Species Act. The Pacific yew has recently been identified as an important source of the cancer-fighting drug taxol, which has shown promise in treating 
women with ovarian cancer. The American Cancer Society is concerned with ensuring that women diagnosed with ovarian cancer in the future will have access to this drug.

Shadbolt, Doris. 1986. Bill Reid. Seattle/London: University of Washington Press. 192 p.

This publication includes a photograph of a carved yew pendant, painted and inlaid with copper and abalone.

Spies, Thomas A. [n.d.]. Plant species diversity and occurrence in young, mature, and old growth Douglas-fir stands in western Washington and Oregon. PNW-GTR xx. Portland, OR: United States Department of Agriculture, Forest Service, Pacific Northwest Research Station. 42 p.

Abstract - The objective of the study was to characterize differences in vascular plant diversity and species abundance among young, mature, and old growth Douglas-fir forest. A chronosequence of Douglas-fir stands was sampled in each of three physiographic provinces: southwestern Washington Cascades; western Oregon Cascades; and southern Oregon Cascades. The cover of all vascular plants was recorded in 177 stands each consisting of 4-to-5 200 $\mathrm{m}^{2}$ plots. Measures of species diversity were calculated for the overstory and understory strata of each stand. Species diversity in each province showed an age-class effect $(p<0.1)$ in 6 of the 12 tests performed. Diversity remained constant or increased slowly with age class. Frequency of occurrence of species showed an age class effect $(p<0.1)$ in 15 -to-20 percent of understory species tested in the provinces. Similar results were obtained in analyses based on species cover, though relative differences between old growth and the other age classes were greater. Species occurring with greatest frequency and abundance in old growth included: Taxus brevifolia, Cornus canadensis and Tiarella trifoliata var unifoliata, understory herbs, and Lobaria.

Stevens, Williams K. 1992. Shamans and scientists seek cures in plants. New York Times. January 28. B5-B9.

Abstract - This article discusses the recent burst of pharmaceutical research aimed at uncovering botanical secrets held by native peoples around the world. Improved technology is allowing companies to screen plants for medicinal agents 
around the clock. The problem lies in the fact that as the earth becomes more populated, natural habitats are destroyed and species become extinct even before they are discovered. This problem is epecially troublesome in the South American rainforests. Conservationists, government agencies, and pharmaceutical companies are finally beginning to join forces to protect the rain forests and, in turn, protect important botanical medicines. Companies are now sending ethnobotanists to native healers around the world to question them about various plants. The plants are then collected and screened for medicinal activity. If the plant is found to contain an active medicinal compound, the researchers isolate the active ingredient and attempt to secure a patent. In one research project in India, scientists used a 2,500 year-old Sanscrit medical text to find a compound helpful in combatting high cholesterol.

Stewart, Wilson N. 1983. Paleobotany and the evolution of plants. New York: Cambridge University Press. p. 348, 360, 361.

Abstract - Included is a table showing suggested origins and relationships of Ginkgoales, Gnetopsida, and major groups of coniferophytes, and their distribution in geological time. Also included are brief discussions of Cephalotaxaceae, Taxales, and Gnetopsida.

Stickney, Peter F. 1980. Data base for post-fire succession, first six to nine years, in Montana Larch-fir forests. General Technical Report INT-62. United States Department of Agriculture, Forest Service, Intermountain Forest and Range Experiment Station. Ogden, UT.

Abstract - Shown are a collection of tables in which Taxus brevifolia is found. The burning units included are North - 6, North - 8, and East - 6 of Miller Creek. 
Stickney, Peter F. 1981. Vegetative recovery and development. In: DeByle, Norbert V., ed. Clearcutting and fire in the Larch/Douglas-fir forests of western Montana - a multifaceted research summary. General Technical Report INT-99. United States Department of Agriculture, Forest Service, Intermountain Forest and Range Experiment Station.

Abstract - During the first six to nine years after burning, development of vegetation on the 20 units studies at Miller and Newman followed a pattern characteristic for forest succession in the Northern Rocky Mountains. This pattern is initiated by an herb stage, which is followed in turn by shrub and tree stages. In these few years, tree development was non-existent or quite limited on most area. Nowhere did trees attain community dominance. Using cover (crown area) of the predominant life form as the criterion for defining the successional stage, it was found that 9 of the 20 units had progressed to the shrub stage. All others remained in the herb stage.

\section{Suffness, Matthew; Snader, Kenneth M; Cragg, Gordon M;} Schepartz, Saul A; Arbuck, Susan; Grever, Michael R. [n.d]. History, Development and Current Status of Taxol at the National Cancer Institute. NCI. Bethesda, Maryland 20892. $36 \mathrm{p}$.

Abstract - This talk presented at the second NCI workshop on Taxus and Taxol is divided into six sections as follows: 1) History and Taxol Development. 2) Status of Clinical Trials. 3) Supply Issues. 4) Research on Production. 5) Basic Research Questions. 6) NCI Research Grants on Taxol.

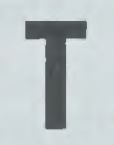

Taxofile. Spring 1992. Newsletter of the Native Yew Conservation Council. 1(1).

Abstract - Includes articles covering the April NYCC public meeting, a recap on events that occurred in 1991, a recap on the 1992 January conference, letters to the NYCC, input to the Pacific Yew Environmental Impact Statement, and more. 
Tirmenstein, Debbie. 1991. Pacific yew - Taxus brevifolia (a summary paper). Missoula, MT: Fire Effects Information System (FEIS), United States Department of Agriculture, Forest Service Intermountain Fire Sciences Laboratory. 28 p.

Abstract - This paper summarizes many facts and characteristics of the Pacific yew. The sections into which the paper are divided are as follows; Species, Distribution and Occurrence, Value and Use, Botanical and Ecological Characteristics, Fire Ecology, Fire Effects, References, and Bibliography.

Tisdale, Sallie. 1991. Save a life, kill a tree? New York Times. October 26.

Abstract - This editorial argues that people are not more important than the Pacific yew tree. The author cautions us to remember where the yew trees and taxol come from: the forests. Destroy that, she says, and we destroy our future. The article is critical of the commercialization of taxol, yew, and the forests in general. The author argues against the idea that we live in a world where people must wage war against nature. "There is one war and it is people versus people."

Turner, Nancy J. 1982. Food Plants of British Columbia Indians. Part 1/Coastal People. British Columbia Provincial Museum, Handbook No. 34. Second Printing, 264 p.

Abstract -The Haida at Masset used to eat yew fruit, but noted that if women ate too many they would become sterile. The Fraser River Lillooet in the Interior also used to eat them, but only in small quantities. The Saanich Indians on Vancouver Island dried yew needles and smoked them in a tube of elderberry stem. It was said to make one dizzy.

Turner, Nancy J. 1979. Plants in British Columbia, Indian Technology. British Columbia Province Museum. Handbook No. 38.

Abstract - The heavy, close-grained wood of yew is well known for its strength and durability. It was prized by all native people within the range of the tree, and was frequently taken into areas where it did not grow naturally. It was used to make bows, wedges, clubs, saddles, digging sticks, adz handles, and harpoon shafts, which were required to handle consider- 
able stress. Although tough and hard, it carves fairly easily taking a high polish. As an indication of its importance as a carving material, yew is called "bow plant" or "bow" in a number of Indian languages including Haida Halkomelem and Lillooet. It is called the "wedge plant" in Sechelt, Squamish, and Mootka. Yew wood was also used to make a variety of other objects including. mat-sewing needles, awls, fish hooks, knives, dishes, spoons, spears, etc.

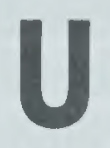

USDA, Forest Service. 1984. Regional guide for the Pacific Northwest Region. United States Department of Agriculture, Forest Service, Pacific Northwest Region.

Abstract - The primary purpose of this Regional Guide is to provide national and Regional direction to the 19 National Forests within the Pacific Northwest Region for land and resource management planning efforts. The Guide facilitates National Forest planning by providing Regional standards and guidelines for addressing major issues and management concerns and by displaying tentative resource objectives for each National Forest, based on objectives that were assigned to the Region as a whole in the National RPA Recommended Program.

USDA, Forest Service. 1990. A paper provided in response to the petition to list Pacific yew as a threatened species. United States Department of Agriculture, Forest Service. November 26. $11 \mathrm{p}$.

Abstract - This paper is a summary of current information about both the species Pacific yew and the implications for the species with respect to the demand for taxol. Addressed in this summary are: the petition to list Pacific yew as a threatened species; taxol as a cancer drug; range of Pacific yew; silvics of Pacific yew; autecology; estimates of availability; current harvest of Pacific yew for bark; future demand for Pacific yew bark; inventory needs; current national forest policies; and management consideration. 
USDA, Forest Service. 1991. Emphasis program. New perspectives in forestry: an ecological path for forest management. United States Department of Agriculture, Pacific Northwest Research Station. 2p.

Abstract - This program is the Pacific Northwest's new program for research, development, demonstration, and applications using an interdisciplinary approach to develop alternative ways to manage forest lands. More complete incorporation of ecological and social values into stand and landscape level practices is expected to reduce future conflicts among competing economic, social, and environmental interests.

USDA, Forest Service. 1991. The Pacific yew and taxol. Briefing Paper. United States Department of Agriculture, Forest Service, Pacific Northwest Research Station. February 25.

Abstract - This briefing paper discusses both the Pacific yew and taxol, an extract of tissues from the Pacific yew. Taxol is first discussed as a relatively successful cancer fighting drug. As the production of taxol from other sources increases, the dependence on bark from "native" Pacific yew is expected to be reduced greatly. Characteristics of the Pacific yew are also provided, including the range the Pacific yew extends, its shrub and tree occurrences, its dioeciousity, and its slow growth. The current harvest of Pacific yew bark is also discussed.

USDA, Forest Service. 1991. Desk guide to tribal government relations. Tribal Relations Advisory Group. United States Department of Agriculture, Forest Service, Pacific Northwest Region. September. $56 \mathrm{p}$.

Abstract -In response to a growing number of questions regarding our government-to-government relations with Indian Tribes in Region 6, this publication has been developed to assist the Region as a whole to better understand the special relationship the United States and its Agencies have with Indian Tribes and tribal governments. This desk Guide is designed to be a reference book and the information will be updated on a regular basis. The basic Forest Service program areas associated with Indian Tribes are: (1) treaty rights; (2) cultural values; (3) the National Forest Management Act, and 
(4) individual Indian rights. This Guide focuses on the Treaty and Other Rights and Tribal Governments aspects of Forest Service responsibilities.

USDA, Forest Service. 1992. An interim guide to the conservation and management of Pacific yew. United States Department of Agriculture, Forest Service, Pacific Northwest Region. March. 78 p.

Abstract - This guide is designed to assist land managers with Pacific yew conservation and management. The Pacific yew has recently been found to contain taxol, an important cancer-fighting drug. Until this discovery, the Pacific yew was essentially ignored by modern society as an important tree species. In the future, taxol is expected to become available through laboratory synthesis and production in non-forest environments, but for the short term, the Pacific yew will be in high demand as a source of taxol. The guide is divided into four parts: I. Executive Summary and Introduction; II. Pacific Yew Biology; III. Yew Management; and IV. Research Needs and Priorities. The appendixes include a list of plant associations and a glossary.

USDA, Forest Service. 1992. Environmental assessment for the 1992 yew bark harvest outside timber sale areas. Nez Perce National Forest, Idaho County, Idaho.

Abstract - Three alternatives for a 1992 yew bark harvest program outside timber sale areas were developed by an interdisciplinary team. Alternative one is the No Action alternative and allows yew bark harvest only within existing timber sale harvest units and road clearing limits. Alternative two, the proposed action and selected alternative, would allow harvest on about 814 acres. Non-yew forage would be improved on moose winter range, some of which show heavy use by moose yet lacks forage other than yew. This alternative is also designed to lessen adverse effects on wildlife security and to harvest on steeper slopes in order to avoid areas preferred by wintering moose. Alternative three allows yew harvest on about 762 acres. Moose forage production would be emphasized on sites managed primarily for timber production rather than on identified moose winter range. This alternative would discourage use of forage by moose and 
elk along Road 286 and reduce moose and elk vulnerability to hunters and poachers. Yew harvest would be generally located on gentle slopes preferred by wintering moose.

USDHHS, Food and Drug Administration. 1988. From Test Tube to Patient: New Drug Development in the United States. FDA Consumer (Special Report). Rockville, MD. January. $58 \mathrm{p}$.

Abstract - This issue is a compilation of articles covering the many different aspects of new drug development. They include a section on how the Food and Drug Administration approves new drugs as well as information on drug legislation. One article provides a general timeline table for development and approval of a new drug, it takes an average of 100 months from initial synthesis to approval of the New Drug Application. There are articles on laboratory and animal studies, and human clinical trials.

USDHHS, Food and Drug Administration. 1987. Guideline for the Format and Content of the Chemistry, Manufacturing and Controls Section of an Application. (Special Report). Rockville, MD. February. 11 p.

Abstract - This guideline is intended to assist drug firms in preparing the chemistry, manufacturing, and controls technical section of applications to market new drugs or antibiotics for human use.

USDI, Fish and Wildlife Service. 1990. Memorandum. Administrative 90-day petition finding for the Pacific yew. (Taxus brevifolia) December 21.10 p.

Abstract - Based on numerous studies, reports, documents, available literature, field sighting records, and interviews, the Fish and Wildlife Service determined that no substantial data exists to warrant listing the Pacific yew as a threatened species under the Endangered Species Act.

USDI, Bureau of Land Management. 1991. Information Bulletin. Oregon State Office, Portland, OR. December 26. $5 \mathrm{p}$.

Abstract - This news bulletin discusses current and planned Pacific yew program activities for the Bureau of Land manage- 
ment. The bulletin includes a list of Annual Pacific Yew Program Plans (APYPP) a summary of the draft PYPP, work summaries for the PYPP task forces and committees, and a list of names and addresses of Pacific yew coordinators for Oregon and Washington.

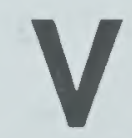

Vidensek, N.; Lim, P.; Campbell, A.; Carlson, C. 1990. Taxol Content in Bark, Wood Root, Leaf, Twig, and Seedling From Several Taxus Species. Journal of Natural Products. 53(6): 1609-1610.

Abstract - Taxol content in various parts of several Taxus species have been determined. The weight percent ranged from 0.00003 to 0.069 .

Viereck, Leslie A.; Little, Elbert L., Jr. [n.d.] Yew family. In: Alaska trees and shrubs. United States Department of Agriculture, Forest Service, Agriculture Handbook No. 410: 43-45.

Abstract - The yew family is classified as one of three families of conifers or softwoods in Alaska in which the seed plants with seeds partly exposed, not enclosed in fruits. The Pacific yew (Western yew) is a small tree or large shrub of extreme south-end of southeast Alaska. Descriptions of leaves, bark, wood, and seeds are included. The Pacific yew has been found in Alaska only on a few islands near Ketchikan. Descriptions of the pine family (Pinaceae) are also included.

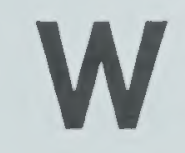

Waterman, T.T. 1973. Notes on the Ethnology of the Indians of Puget Sound. Indian Notes and Monographs. Misc. Series No. 59. Museum of the American Indian. Heye Foundation. New York. 97 p.

Abstract -The most desirable paddles were made of yew.... The Puget Sound adze is a very effective instrument, used for a wide variety of purposes. It has a very short handle (usually of vine maple, sometimes yew) which is carved to fit the hand. Wedges and the foreshafts of bird spears were also made of yew. 
Welsh, Stanley L. [n.d.] Anderson's flora of Alaska and adjacent parts of Canada. $38 \mathrm{p}$.

Abstract - This entry provides a brief description of the yew family (Taxaceae), including the Western yew (Taxus brevifolia). A sketch of the Western yew is also shown.

\section{Witherup, Keith M.; Look, Sally A.; Stasko, Michael W.,} Ghiorzi, Thomas J.; [and others]. 1990. Taxus Spp. needles contain amounts of taxol comparable to the bark of Taxus brevifolia: analysis and isolation. Journal of Natural Products. 53(5): 1249-1255.

Abstract - New sources for the antitumor natural product taxol [1] are needed as demands for this promising cancer chemotherapeutic agent increase. Presently, supplies of taxol for clinical studies are obtained from the bark of Taxus brevifolia, a potentially limited source. Using analytical methods, the needles and stems of six Taxus species have been examined for taxol [1] and 10-deacetylbaccatin III [5], a related compound that can be converted to taxol through a semi-synthetic route. Amounts of taxol comparable to quantities reported from the bark of $T$. brevifolia were found in the needles of four of the Taxus species investigated. In addition, taxol was isolated from the needles of one Taxus species. Thus, Taxus needles may provide a renewable source of this valuable compound.

Wood, Wendell. 1991. Conservationists promise legal action if yew wasted. Statement. Oregon Natural Resources Council. March 11.

Abstract - The Oregon Natural Resources Council announced on March 11 that they would bring legal action against the Willamette National Forest under the Clean Air Act unless the forest fully complies with Oregon's smoke management plan, and better utilizes all downed yew trees discarded in slash piles.

Wright, Michael H. 1988. Stalking the Western Yew.

Woodenboat Magazine. May/June: 72-73.

Abstract - Discusses boat construction with Taxus brevifolia. 

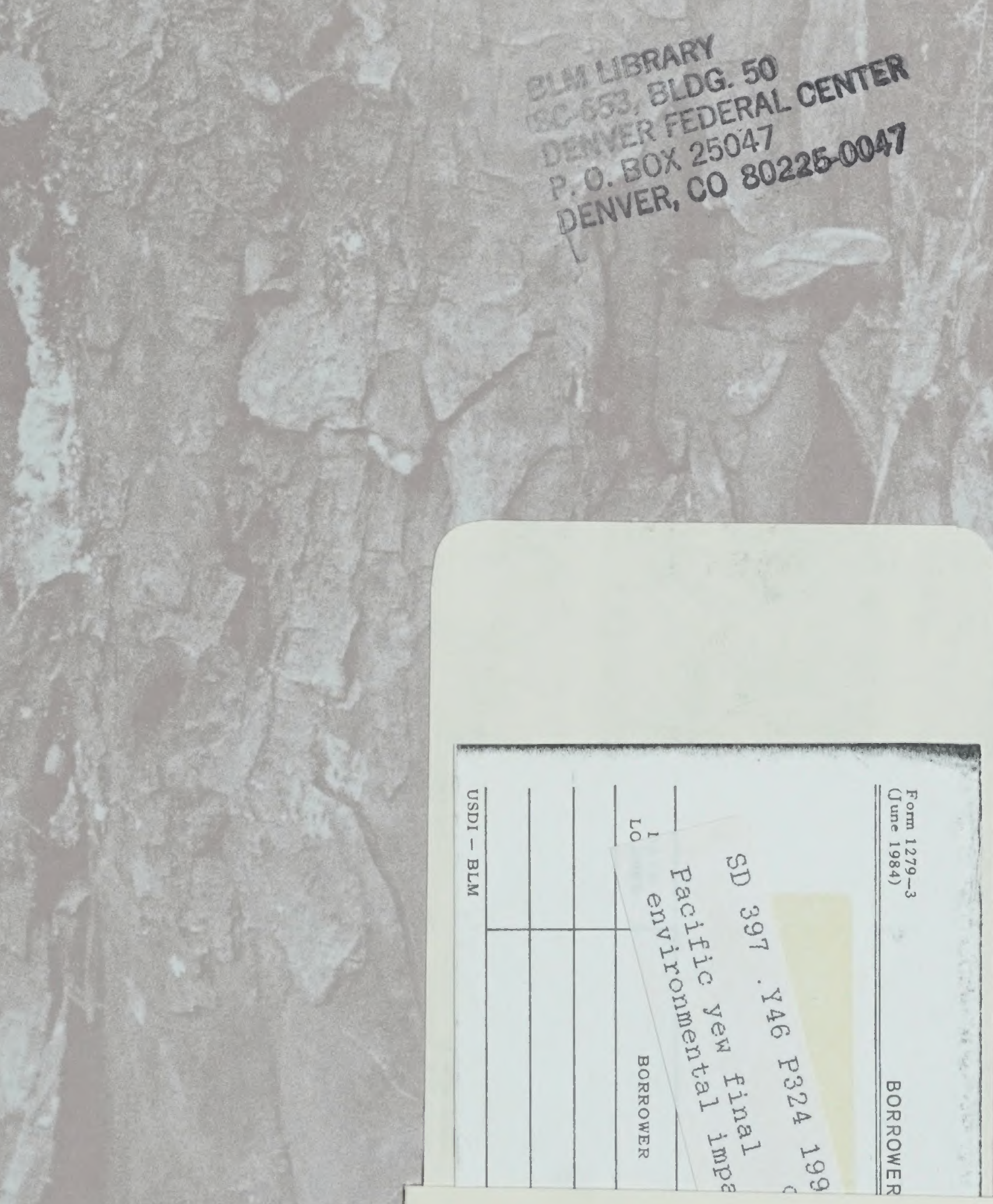

BLM LIBRARY

5C.653, BLOG. 50

DENVER FEDERAL OENTER

P. $0.30 \times 25047$

DENVER, CO 80225-0047 
